\title{
COOPERAÇÃO INTERMUNICIPAL NO ÂMBITO DO SUS
}

\section{ANTONIO ALVES RODRIGUES}

Orientador: PROFA. DRA. BASÍLIA MARIA BAPTISTA AGUIRRE

\section{São Paulo}

2003 


\section{ABSTRACT}

A study on the interactions between several agents that could be involved with the arrangement of an intermunicipal cooperation facing the public policy of health has taken place. We could observe that the formatted structures happen as a linear combination of plenarily spontaneous, when, thus, there is the interaction of the personages at a municipal level, totally induced, when, hence, the coercion capacity set forth by the Union is enough to induce municipal districts to adopt a resourcesharing deportment at a regional level. Nevertheless, the study has verified that some variables interfere in the formulation of a structure of cooperation, such as the externalities, motivation and incentives, institutions and its modifications, the capacity of coordination and solubility of informational asymmetry, among many others. Therefore, we have designed a theoretical structure sustained on the theories of traditional public finances, of public choice, of contracts and on the institutional, aiming to crumble two diametrically polarized examples: the formulation of the cooperation as a coalition through an inter-municipal consortium and the arrangement of cooperation as pacts, which are made by the institutionalization of operational norms edited by SUS. 


\title{
INTRODUÇ̃̃o
}

\author{
É possível a cooperação entre entes federativos municipais em um ambientefederativo \\ competitivo? \\ Épossivel que alguma instituição induza a cooperação intermunicipal?
}

Em meio às possíveis soluções para as externalidades em uma região metropolitana e o comportamento oportunístico dos indivíduos, em especial, o das elites políticas envolvidas em uma guerra fiscal, encontramos o tema deste trabalho: a cooperação intermunicipal.

A concepção do tema evoluiu para o setor de saúde pública, em especial, por três razões: o pacto federativo que municipaliza a responsabilidade de sua prestação, com impacto nos orçamentos públicos, embora podendo ser financiada por meio de transferências vinculadas às normas impostas pelo SUS; as externalidades nesse setor; $\mathrm{e}$, as regras de acesso que limitam o monitoramento dos residentes que procuram serviços de saúde em outros Municípios, que não o de sua jurisdição.

Para o estudo do tema, basicamente adotamos a teoria de finanças públicas, a teoria de escolha coletiva, a teoria dos contratos e a economia institucional. Adotaremos pelo menos dois personagens para o desenvolvimento do tema, sendo que um seriam os Municípios, com suas elites políticas motivadas por um federalismo mais competitivo do que cooperativo, administrando suas políticas de alíquotas tributárias com disposição à "guerra fiscal" e, com os residentes e proprietários dos fatores influenciando as relações intermunicipais a partir de sua mobilidade. O outro personagem será a União, em especial o Sistema Único de Saúde - SUS, uma organização normatizadora das ações de saúde publica a nível nacional. Tal elenco influencia a eficiência distributiva horizontal, a existência de externalidades, e a condução da política de saúde pública para o bem estar social regional, seja ela induzida ou espontânea.

Em razão disso, principiaremos por analisar o tema sob foco do federalismo fiscal a partir de uma visão normativa da teoria tradicional. Consideraremos que o ente 
municipal possui uma estrutura tributária própria, além de ser um receptor líquido de transferências financeiras vinculadas ou não. Uma hipótese a ser testada é se a capacidade de receita influencia na disposição dos Municípios a adotar um dado padrão de gastos públicos de saúde e, dessa forma, estender essa disposição a um eventual pacto de divisão de "responsabilidades" entre Municípios pela otimização regional na prestação de serviços públicos de saúde.

Ao tratarmos de cooperação intermunicipal em meio à teoria do federalismo fiscal, pretendemos nos concentrar nas questões horizontais, tais como: externalidades, competição tributária, transbordamento dos benefícios de despesas públicas de um dado Município em outro. Nessa análise, ao se graduar a mobilidade dos indivíduos e dos fatores de produção de serviços de saúde pública, estaremos também nos deslocando dentro do modelo de Tiebout, onde um indivíduo escolhe o padrão de serviço sem qualquer restrição.

Evidentemente, a competição tributária tem grande influência na mobilidade e nas interações dos diversos entes federativos envolvidos, inclusive a União, pois, ao inferirmos que a competição tributária representa um comportamento não cooperativo dos Municípios, exigem-se políticas regulamentadoras da União. Daí resulta interessante um estudo comparado entre Musgrave e Tiebout, pois, enquanto Musgrave não acredita numa solução de mercado que determine o nível de gastos públicos pelos entes federativos, Tiebout mostra que essa abordagem não necessariamente se aplica aos gastos municipais, pois estes refletem as preferências dos residentes mais adequadamente do que a informação capturada pela União e, portanto, evidenciando a questão de como revelar essas preferências.

Neste ponto, convém lembrarmos que uma parte da literatura trata o tema da alocação de bens e serviços a partir de uma perspectiva diferente considerando a União como um ente monolítico capaz de lidar com as ineficiências que surgem das relações intermunicipais, sem qualquer atenção às questões de informação assimétrica ou de coordenação. Essa constatação já nos predispõe a não nos restringirmos unicamente às estruturas federais que criam as externalidades tributárias horizontais ${ }^{1}$, pois, afinal, a

\footnotetext{
${ }^{1}$ No caso do federalismo fiscal brasileiro, não há o que se falar em externalidades verticais à medida que os diversos tipos de entes federativos não tenham bases tributárias comuns de modo que as decisões de
} 
essência de federalismo é composta de vários níveis de governo e, desse modo, para o embasamento da questão institucional do SUS, embora atuando como um planejador centralizado, torna-se indispensável o conhecimento da literatura de federalismo fiscal que também considere as relações verticais regradas pelo pacto constitucional e, que são viabilizadas com as transferências financeiras.

Ou seja, a União, por meio do SUS, deverá ser mais uma personagem entre os diversos entes federativos, pois, a imagem de eficiência econômica de um estado único, capaz de automaticamente acomodar todas as interações entre os personagens, se descola da realidade imposta pelo contrato constitucional que divide bases tributárias e responsabilidades de gastos públicos entre essas mesmas personagens.

Numa visão federalista, os Municípios ao constituírem "de baixo para cima” uma estrutura de cooperação estarão preocupados que a burocracia deste extrapole suas atribuições. Em razão disso, trataremos deveremos nos preocupar com as restrições à discricionalidade da burocracia, além da prevenção de pressões de grupos de interesses.

Por outro lado, se conjugarmos essa visão federalista com a divisão de responsabilidades fiscais, então, não há como evitarmos tratar de questões como a alocação adequada das funções fiscais entre os diferentes entes federativos, o grau de comprometimento com as responsabilidades, as diversas políticas de alíquotas tributárias, o papel das transferências financeiras intergovernamentais verticais e horizontais e, o regramento do SUS às ações voltadas para políticas públicas de saúde.

De qualquer forma, nossa discussão da política pública da saúde se dará num ambiente de federalismo fiscal onde haja pelo menos dois níveis de tomada de decisão, o que nos remete à análise do grau de centralização da tomada de decisão. Até porque, num tema sobre integração regional, sempre surge a questão da distribuição de responsabilidades entre os Municípios envolvidos. Sobre o grau de centralização, de imediato, devemos ter em mente que há diferentes Municípios, na medida em que possuam uma composição de residentes com diferentes funções utilidade sobre a integração proposta, além de quase sempre estarem em desacordo sobre quais recursos

política tributária de um afetassem o tributo do outro. Esse tipo de externalidade surge mais obviamente quando ambos os entes federativos detêm poderes de tributar o mesmo tipo de base tributária. 
seriam transferidos à estrutura da cooperação e, quão dispostas estariam a mudar suas respectivas políticas de alíquotas tributárias.

A teoria tradicional poderia nos suprir quanto à motivação pela cooperação e ao compromisso político pela sua estruturação, a partir de uma perspectiva de maximização do bem estar social sob a ótica de um planejador benevolente pigouviano, a semelhança do SUS, que ao centralizar as suas decisões sobre política pública de saúde, poderia internalizar externalidades e, então, ampliando sua capacidade informacional, pudesse, por meio de incentivos na forma de transferências financeiras, induzir as decisões descentralizadas nos Municípios, uma vez que estes detêm um melhor conhecimento das preferências e condições dos indivíduos que demandarão os serviços de saúde pública.

O interessante é que, se a discussão se resumisse apenas à questão da descentralização versus centralização da tomada de decisão, teoricamente o enfoque pigouviano em favor da tomada de decisão centralizada da política pública de saúde poderia ser eficiente desde que as externalidades não fossem grandes e os serviços fossem prestados eficientemente. Entretanto, em geral, os sistemas autônomos municipais de saúde são ineficientes, a ponto de os Municípios "encorajarem" a mobilidade de seus residentes, ou, por meio da competição tributária, incentivar o deslocamento dos fatores de produção desse serviço.

Também abordaremos as motivações e incentivos eleitorais no comportamento das elites políticas municipais com base na presunção que fazem da quantidade de bônus políticos (votos) que obteriam numa tomada de decisão de cooperar ou não. O interessante desta hipótese é que sendo possível a divisão de riscos e resultados entre os Municípios, abre-se espaço para uma coordenação horizontal, além da possível vertical quando exercida pela União e Estados. E, sendo possível alguma coordenação horizontal, então também seria possível que a estruturação de uma cooperação intermunicipal das ações públicas de saúde numa dada região fosse espontânea.

De qualquer forma, em meio a motivações e limitações à cooperação, é necessário que as elites políticas municipais se disponham a regrar formas de transferência financeira horizontal. Afinal, a viabilidade da cooperação intermunicipal 
passa pela resolução de seu financiamento, sendo notória a dependência dos Municípios brasileiros às transferências financeiras e a influência destas em sua autonomia, ainda que a constituição lhes garanta uma base de recursos tributários própria.

Portanto, questões como as externalidades e a otimização das estruturas existentes de prestação de serviços revelam-se incentivos à cooperação intermunicipal, conquanto seja possível algum arranjo institucional que sinalize com a maximização dos recursos disponibilizados coletivamente, a exemplo do consórcio de saúde.

Quanto mais espontânea for a estruturação da cooperação, mais "pura” tende a ser a integração horizontal, ou seja, mais sujeita estará aos aspectos da negociação ocorrer entre agentes políticos iguais, em que as regras de acesso e exclusão, como num clube, assumem características próprias. Além disso, há que se considerar a capacidade e o interesse de os Municípios em custear com recursos próprios as ações de saúde pública, principalmente, as coletivas.

Portanto, é necessária a análise dos conflitos de interesses fiscais na região, pois podem ser inibidores da cooperação regional, na medida em que a disponibilidade de financiamento das ações cooperadas de saúde pública se vincule à obtenção ou ampliação de recursos próprios. Além disso, há que se tecer considerações que envolvam questões de teoria de escolha pública voltadas à tomada de decisão dos Municípios ser pró ou contra a cooperação.

Para isso, utilizaremos a literatura sobre a integração européia, a qual, ao tratar da ruptura de barreiras à mobilidade de fatores e pessoas num processo de estruturação de uma coalizão, traz subsídios à cooperação intermunicipal na medida em que esta dependa de políticas que permitam, além da mobilidade de fatores e indivíduos, tal qual em Tiebout, o acesso universal a um padrão desejado de serviços.

Uma outra hipótese é a política de alíquota tributária ter uma estreita relação com a competição tributária e, com base nela, evidencia-se a importância do ambiente político e do conceito de custo de transação. No entanto, o conceito de custo de transação tem maior intimidade com o setor privado, razão pela qual, o redefinimos como custo político, associando-o com as decisões das elites políticas sobre as várias políticas adotadas. Com isso, esperamos endogeinizar o efeito das assimetrias entre as elites políticas, quer seja no envolvimento em "guerra fiscal", quer seja no 
comprometimento com transferências horizontais voltadas a manutenção de uma estrutura de cooperação. Ou seja, os custos políticos estariam associados a qualquer ampliação de alíquotas tributárias mesmo que justificada politicamente pela ampliação do financiamento de serviços públicos de saúde.

E, da teoria dos contratos aplicada à constituição de uma estrutura de cooperação intermunicipal, inferimos que os efeitos desses custos deveriam ser considerados e minimizados com cláusulas que obriguem o repasse horizontal das cotas parte, bem como, regulem não só o acesso aos serviços, mas também regras críveis de exclusão dessa estrutura.

Além disso, podemos inferir que um processo de escolha coletiva, que proporcione um mecanismo de preferência revelada dos residentes às respectivas elites políticas, pode ampliar a eficiência da tomada de decisão dessas elites políticas municipais, tanto pela receita, quanto pelos gastos. E, se isso é verdade, então esse mesmo mecanismo ${ }^{2}$ também pode ajudar na definição do equilíbrio de transferências recursos a uma estrutura de cooperação.

Uma outra hipótese é que a competição tributária tem uma correlação inversa com a cooperação intermunicipal e, com a disposição dos Municípios em aderir a uma estrutura de cooperação. Por outro lado, a literatura que trata a competição tributária, o faz para explicar níveis de eficiência na produção de serviços por meio de políticas de alíquotas tributárias, em geral, voltadas a expulsar, atrair ou manter determinados investimentos.

Ou seja, os Municípios, dado os interesses, podem adotar choques tributários sobre fatores que influem nos custos marginais de um investimento voltado à prestação de saúde pública. Porém, esses choques podem reduzir a receita tributária e, portanto, os gastos com alguns serviços públicos podem vir a níveis ineficientes. E, se os Municípios assim se comportarem, além de se reduzir qualquer vantagem competitiva entre eles, se ampliariam os custos políticos a incorrer na estruturação da cooperação.

\footnotetext{
${ }^{2}$ Evidentemente, para que isso seja possível, é necessário que as elites políticas municipais possuam recursos, ferramentas, para adaptar seus sistemas de alíquotas tributárias aos interesses dos consumidores-eleitores, que se expressam coletivamente segundo alguma regra de maioria. Além disso, essas ferramentas devem possibilitar as elites considerarem em suas tomadas de decisões os custos políticos, além dos demais outros que advêm de um novo sistema de alíquotas.
} 
De qualquer forma, o que está por trás dessa discussão são as necessárias transferências de recursos horizontais na formação de uma cooperação, embora, seja também interessante abordarmos uma possível competição entre os Municípios pelas transferências verticais da União, por meio do SUS, praticando políticas de alíquotas tributárias que incentivassem atrair ou manter fatores de produção de serviços de saúde.

Agora, retomemos a questão da divisão de riscos e resultados de uma estrutura de cooperação intermunicipal. Para isso é necessário se analisar os incentivos e instituições que possam ser desenhados, sem nos omitirmos de considerar as perdas de autonomia político-financeira dos Municípios com a formatação de uma estrutura de cooperação, quase sempre com uma burocracia própria, e, também devemos considerar o sistema de transferências de recursos, quer seja vertical ou horizontal.

Afinal, o estudo da divisão de riscos envolve comportamento oportunístico, de tal forma que algumas elites políticas podem sub-avaliar os incentivos à cooperação, requerendo monitoramento e regulamentação que ajustem o respectivo comportamento ao compartilhamento de riscos projetado. Essa função pode ser atribuída à União, por meio do SUS, ou a alguma entidade supra-municipal que administre a estrutura de cooperação, desde que possam graduar os incentivos, quer sejam positivos ou negativos.

No entanto, a decisão pela estruturação de uma cooperação, além de diretamente coletiva a partir da vontade política de várias elites, é tomada, em geral, também com base em outras decisões indiretas e coletivas. Ou seja, é tomada a partir de uma representação eleita pelos indivíduos residentes, que além de eleitores, são os consumidores do serviço proposto, daí denominados por consumidores-eleitores.

Porém, os consumidores-eleitores se fazem representar indiretamente nas três esferas de governo. Em assim sendo, abre-se espaço a um "contra-fluxo hierárquico" de tomada de decisão das elites políticas municipais, pois, legitima-se a normatização e centralização da política pública de saúde na União, por meio do SUS e, o controle e a coordenação deste sobre todos os sistemas de prestação de serviços de saúde pública, principalmente, os municipais. Talvez, seja esse um dos motivos pelo qual a União tenha estruturado o SUS como um sistema social de produção baseado em uma “hierarquia pública” (como veremos amiúde no decorrer deste trabalho). 
Um ponto interessante que encontramos na literatura de federalismo fiscal é a defesa que esta apresenta das decisões políticas centralizadas, por exemplo, na União. Em geral, essa defesa objetiva compensar distorções nas decisões coletivas das elites políticas municipais, principalmente, porque se pressupõe pautadas em comportamentos oportunisticos. Um de nossos pressupostos é de que essas ineficiências, que também afetam a estruturação da cooperação intermunicipal, se correlacionam com a mobilidade das bases tributárias e a competição tributária.

Porém, avaliar a motivação dos indivíduos em estruturar uma cooperação a partir da teoria do federalismo fiscal tem algumas limitações. Afinal, essa teoria se baseia na de finanças públicas, que, por sua vez, advém da teoria do consumidor, a qual trata da escolha individual, e não da escolha coletiva.

Além disso, a questão político-econômica da descentralização ${ }^{3}$ versus centralização ${ }^{4}$ fiscal, repercutindo tanto na estrutura e nas normas emitida pelo SUS, quanto na estruturação da cooperação ser por indução ou espontânea. Portanto, para lidarmos com essa ineficiência, manteremos o enfoque da teoria tradicional sobre as funções $^{5}$ de governo alocação e redistribuição, de modo a explicar, no caráter normativo do SUS, uma combinação dessas funções entre os três entes federativos, que culmina com o modelo de regionalização, cuja indução à cooperação é institucionalizada com a edição da NOAS-SUS 01/01.

Ou seja, e também nos remetendo ao modelo de Tiebout e suas extensões, o SUS, inicialmente se comportando como um planejador central, tenta a nível nacional

\footnotetext{
${ }^{3}$ Reescrevendo para o aspecto do serviço público de saúde, a literatura apresenta como argumento favorável à anti-concentração da tomada de decisão a possibilidade de ofertar eficientemente padrões diferenciados de serviços. Por outro lado, também exige baixos custos de mobilidade intermunicipal, nos remetendo às considerações geográficas e de diferença de renda entre os diferentes grupos de consumidores-eleitores que compõem a região.

${ }^{4}$ Como argumentos pró-concentração da tomada de decisão sobre o serviço público de saúde, temos a economia de escala na produção desse serviço e a internalização de externalidades que causam problemas de competição fiscal. Sob o aspecto redistributivo, um sistema de redistribuição intermunicipal poderia trazer segurança contra específicos choques setoriais; além de uma potencial redistribuição regional para um nível de bem estar social maior do que o possível obtido de vários Municípios agindo individualmente.

${ }^{5}$ As funções distribuição e estabilização seriam mais adequadas centralizadas na União, embora, se possa falar em distribuição regional por meio de uma coalizão intergovernamental.
} 
reproduzir padrões de serviços municipais de saúde a todos os Municípios, a partir de uma informação limitada a cerca da função utilidade da maioria dos indivíduos e, subestimando os problemas redistributivos e a diversidade das necessidades dos indivíduos. Veremos que esta idéia foi, com o aprendizado, sendo substituída pelo conceito de regionalização, na medida em que o SUS incorpora às normas emitidas, a regulamentação de uma estrutura de cooperação formatada por convênios contratuais de acesso envolvendo os Municípios de uma dada região com o respectivo Estado.

A teoria tradicional também se mostra favorável à centralização da tomada de decisão em razão das economias de escala na produção de serviços públicos de saúde. Porém, se assim fosse, era de se esperar que esse ganho de eficiência se desse na proporção com que haja pouca variação no padrão de serviços demandados pelos residentes dos Municípios, o que de certa forma explicaria porque o SUS normatiza, indistintamente, poucos padrões de atendimento a todos os Municípios do Brasil.

Afinal, em caso contrário, haveria Municípios com custos de oferta excedendo os benefícios e, havendo "transbordamentos", certamente algum desses Municípios seria o "doador líquido" de serviços de saúde em relação aos outros. Essa perspectiva só seria incorporada às normas do SUS, após mudanças institucionais incrementais que culminaram com o modelo de regionalização por meio da edição da NOAS-SUS 01/01.

Portanto, a hipótese da economia de escala presente na teoria tradicional não conseguiria explicar plenamente o compartilhamento de recursos que proporcionam qualidade distinta de serviços de saúde pública e, além disso, não poderia explicar porque os Municípios, espontânea e descentralizadamente, decidiriam se estruturar com o objetivo comum de prestar esses mesmos serviços especializados a seus respectivos residentes, quando não disponíveis em seus sistemas autônomos.

Além disso, a decisão descentralização nos Municípios tende a ser eficiente, na medida em que estes capturem as informações melhor que a União, principalmente, as referentes à quantidade e qualidade dos serviços esperados. Dessa forma, a decisão descentralizada também teria uma maior a eficiência redistributiva na medida em que essas informações também dissessem respeito às diferenças de preferências e de renda e à mobilidade dos fatores e indivíduos na região. 
Portanto, nos voltamos à teoria da escola da escolha coletiva para explicar como um grupo jurisdicional de consumidores-eleitores, através um processo ${ }^{6}$ político organizado, alcança um consenso sobre como, por quem e quais padrões de serviços públicos deveriam ser ofertados. Observe-se que esse processo político se dá sob regras democráticas e, tendo a democracia representativa uma correlação direta com a descentralização da tomada de decisão, inferimos a necessidade de se avaliar a capacidade desses indivíduos, que escolheram os representantes que tomam decisão em seu nome, de monitorar eficientemente a ação pública desses representantes.

Além do mais, há que se analisar o grau de compromisso que as elites políticas têm com suas promessas de campanha, que neste trabalho assumirão a função de aferição do mecanismo eleitoral de revelação das preferências da maioria dos consumidores-eleitores, a ser desenvolvido a partir do modelo de Dixit e Londregan (1998). Observe-se que, desconsiderar essas preferências na descentralização ou centralização da tomada de decisão pela cooperação intermunicipal pode afetar tanto a formatação dessa estrutura, quanto o posterior equilíbrio de poder em razão de confrontos de grupos de interesse na região. .

Porém, se "toda moeda tem duas faces", então, o processo político de tomada de decisão coletiva pode também ser ineficiente com os conflitos de interesse sobre a tomada de decisão de se estruturar, ou não, uma cooperação. Ou seja, quanto mais democrático for o processo de decisão coletiva, maiores seriam as indecisões coletivas, maior a possibilidade de se manter o "status quo" e, maior a possibilidade de surgirem “caronistas" entre os tomadores de decisão, dada a racionalidade individual.

Além disso, para que a cooperação ocorra é necessário que os incentivos sejam seletivos em razão do tipo de Município e, que sejam percebidos como positivos ou negativos, de tal modo que os indivíduos tomadores da decisão pró ou contra cooperação, a partir de alguma homogeneidade de seus membros, percebam a heterogeneidade entre os grupos. Se isso é óbvio, então sob a ótica de um dado Município, é possível imaginar que os seus residentes tomem uma decisão coletiva da

\footnotetext{
${ }^{6}$ O processo de escolha coletiva pode ser visto como uma extensão do modelo de maximização da utilidade aplicado a um consumidor-eleitor mediano, dependente dos arranjos político-institucionais e
} 
mesma forma que o seu representante, o consumidor-eleitor mediano, decida pela lógica da racionalidade econômica, maximizar sua utilidade escolhendo entre opções conhecidas.

É por isso que o conceito de racionalidade limitada, dada a informação imperfeita e o comportamento oportunístico, deve também ser investigado pela sua correlação com os custos políticos de uma tomada de decisão. Por esse enfoque, o SUS seria uma organização que minimiza custos políticos, na medida em que assume boa parte dos ônus da condução da política pública de saúde no país. Da mesma forma, a existência de uma estrutura de cooperação intermunicipal poderia ser explicada pelo comportamento individual das elites políticas municipais que, através dessa estrutura, dividiriam os ônus e bônus políticos com as demais numa dimensão regional.

Porém, ainda que essa estruturação seja espontânea, admitiremos que a União, por meio do SUS, não só limita, como também molda o comportamento individual das elites municipais, de modo que a ação coletiva das elites municipais seja também induzida pelas normas instituídas pelo SUS e, as suas mudanças. Observe-se que tal hipótese vincula as regras de comportamento das elites políticas municipais com o ambiente político-institucional, no qual essas mesmas regras funcionam e são regulamentadas pela União por meio do SUS.

Analisados os incentivos e motivações na estruturação da cooperação, passaremos à analise de como conferir a essa estrutura suficiente estabilidade e credibilidade. Isso implica que o contrato constitutivo contenha regras que protejam os direitos de propriedade, ao mesmo tempo em que sejam críveis as ameaças a quem não contribuir para a manutenção da cooperação.

Essas regras devem também prever limitações auto coercitivas e sustentáveis à discricionalidade da burocracia da coalizão, ao mesmo tempo em que estrutura uma governança que sinalize a todos os residentes da região a segurança institucional esperada, evitando, inclusive, a formação de conluios ou sub-estruturas na região.

Evidentemente, decidir pela não transferência horizontal de recursos ou serviços significa um “não" aos compromissos pela cooperação, em geral, firmados 
num contrato. Por outro lado, esses compromissos poderiam não ser suficientes para se evitar os efeitos de transbordamento entre os Municípios envolvidos, na medida em que for mais acentuada a heterogeneidade das preferências dos residentes num dado contexto de regras de tomada de decisão.

Ou seja, decisões são tomadas não somente sobre a política pública de saúde, mas também sobre outras, as quais podem representar incentivos "complementares" à tomada de decisão sobre a política pública de saúde e, assim sendo, admitiremos que há diferentes graus de propensão a cooperar, na proporção em que os consumidoreseleitores e as elites municipais percebam sua decisão integrável, ou não, às demais políticas públicas.

Quanto às transferências financeiras, em especial as verticais normatizadas pelo SUS, podem ser enfocadas como o exercício da função de redistribuição de renda. Se o principal instrumento de redistribuição são as transferências, então, os Municípios com as transferências horizontais estariam exercitando um instrumento redistributivo regional, em complemento à eficiência esperada da União. Talvez por isso, a União por meio do SUS, ao lado da estrutura criada para monitorar e capturar informações, também buscou instituir a interação com os demais entes federativos por meio de secretarias especiais e das chamadas Câmaras Intergestoras.

Assim sendo, para que o efeito obtido de um programa de transferências instituído pela União se aproxime do pretendido, as elites políticas estaduais e, em especial, as municipais, devem, em suas respectivas peças orçamentárias, prevê-los dentro das especificidades e prioridades normatizadas. Portanto, dada as assimetrias informacionais no desenho dos programas de redistribuição, admitiremos também existe uma assimetria orçamentária entre os Municípios de uma região.

Afinal, qualquer política redistributiva da União afeta muito mais a disposição dos Municípios em arrecadar de sua base tributária própria, do que uma política regional de distribuição de renda, observável na estruturação da cooperação espontânea, é capaz de afetar a disposição da União em transferir recursos. Assim sendo, admitiremos que essa pode ter sido uma das razões para que a União, por meio do SUS, sinalizasse com a NOAS-SUS 01/01 a sua intenção de regionalizar algumas ações de saúde pública, induzindo a formatação de estruturas de cooperação 
intermunicipal e, utilizando o instrumento tributário das transferências verticais. Dessa forma, a União ampliaria os efeitos de sua assimetria informacional, além de robustecer as questões atinentes ao monitoramento das ações de saúde pública.

De qualquer forma, admitiremos que as elites políticas municipais estão propensas a ampliar o bem estar da maioria de seus residentes, embora sujeitas aos limites com as receitas, as responsabilidades com gastos públicos e os compromissos assumidos. Além disso, as consideraremos conscientes de que quaisquer alterações nesses parâmetros causam custos políticos.

E, quanto às questões distributivas, as consideraremos tanto sob o foco da União, quanto nos Municípios. O problema é que a redistribuição horizontal tende a ser ineficiente na medida em que os residentes se fazem representar pelas respectivas elites políticas, o que implica na fraca disposição destas em tributar bases próprias, preferindo as transferências verticais, ainda que condicionadas pelo SUS.

Em razão disso, presumimos que as elites políticas se preocupem com o custo político advindo da ampliação de gastos numa adesão à cooperação regional, seja ela espontânea ou induzida, avaliando esse custo sob duas óticas: a de se tomar uma decisão que não descole das preferências da maioria dos consumidores-eleitores e a de não ampliar as alíquotas tributárias em razão do equilíbrio orçamentário.

Até porque os Municípios e a União, por meio do SUS, podem não ter os mesmos objetivos para o setor de saúde pública, o que significa que as normatizações propostas pelo SUS podem não dominar as relações entre esses entes federativos, se não outros incentivos, como as transferências financeiras. Isso significa que as interações entre Municípios e União não se assemelham a agente-principal, mas sim, a uma interação entre iguais.

Em outras palavras, devemos aceitar a hipótese de que, com a autonomia municipal, a estrutura federativa brasileira não estabelece suficiente hierarquização entre os entes políticos que permita o uso da teoria de agente-principal para explicar as motivações à cooperação intermunicipal. Note-se que estamos conjeturando sobre as interações entre Municípios e União, e não a que se refere aos Municípios com a organização SUS, a qual, embora estruturada como uma "hierarquia pública", não tem 
proeminência sobre a tomada de decisão de um Município em aderir, ou não, às suas normatizações.

É por isso que, sendo a negociação vertical também entre iguais, inferimos a necessidade de se incorporar à análise o grau de descentralização de tomada de decisão das políticas públicas, uma vez que a União, os Estados e, os Municípios, possuem e fazem uso de seus poderes independentemente.

Porém, isso pouco facilita a análise, pois a decisão de se estruturar ou não a cooperação intermunicipal se dá ao nível dos Municípios e não poderemos tratá-los como iguais, reconhecendo-os diferentes e, portanto, demandando esforços de coordenação diferenciados e incentivos seletivos. De qualquer forma, o que se prevê na formatação de uma cooperação intermunicipal é, no mínimo, a busca de uma solução ao desequilíbrio horizontal na prestação dos serviços de saúde pública, voltada à equalização do acesso e à coordenação de gastos numa dada região.

Se há um ponto a ser ressaltado neste momento é o de que o foco deste trabalho está no SUS. Tanto é verdade, que lhe dedicamos um capítulo para evidenciar as mudanças institucionais ocorridas, a correlação dessa evolução com a indução à cooperação intermunicipal e a forma com que imprime a coordenação. Um detalhe que será mais bem clarificado no transcorrer deste trabalho é que a medição da eficiência de uma cooperação intermunicipal pode seguir alguns critérios.

Para uma estrutura tendente a espontânea, provavelmente, o critério seria quantificar a satisfação da qualidade esperada pelo consumidor-eleitor-mediano, expressa em voto por uma regra de maioria simples. No entanto, veremos que o SUS avaliará por critérios puramente qualitativos, tais como os aspectos discretos conferidos pelo acesso irrestrito e universal ao serviço em dadas regiões, ou ainda, o aspecto agregado de padrão equanimente ofertado por todos os Municípios.

De qualquer forma, a busca pela cooperação intermunicipal, seja a partir das elites municipais adotando um comportamento cooperativo nas ações de saúde pública, seja pelo SUS induzindo a cooperação com as mudanças institucionais ocorridas, devemos ter em mente que a avaliação da eficiência da cooperação sempre dependerá da racionalidade limitada dos agentes econômicos envolvidos. Ou seja, é necessário se ter em mente que o custo político, que está no âmbito da racionalidade limitada, surge 
da diferença de avaliação que os diferentes agentes econômicos fazem da incerteza e do risco de se aderir ou induzir à cooperação intermunicipal.

Em assim sendo, podemos formalizar uma primeira diferenciação entre a cooperação induzida e a espontânea. Se a negociação pela cooperação é conduzida por regras e metas comuns, consentidas e até impostas por uma autoridade, cuja ameaça é crível, quase sempre expressam em si uma "ordem" pela cooperação entre os agentes. Por outro lado, se a negociação for conduzida espontaneamente por um interesse qualquer mútuo entre agentes simetricamente correlacionados, pode também originar a cooperação entre eles. Além delas, entre uma situação e outra, estão as negociações realizadas com assimetria de informações entre os agentes.

De qualquer forma, a cooperação é estruturada quando os agentes cooperam para alcançar uma meta em comum. Em geral, a cooperação é estruturada por um contrato, formal ou não, que expressa o cálculo de otimização que cada uma das partes faz da organização desde que satisfaça um interesse mútuo.

No caso do SUS, poderemos identificar em sua estrutura normativa a intenção de se coordenar um processo de cooperação regional, além de sinalizar qual o "ambiente institucional" que o SUS persegue. Agora, se adicionarmos o incentivo das transferências verticais, acreditamos poder "corporificar" a indução à cooperação intermunicipal.

Também pretendemos identificar na estrutura do SUS a tentativa de se sincronizar a demanda e a oferta de serviços de saúde pública, de se regulamentar a polarização regional, de se terem efeitos redistributivos, de se facilitar a expansão de informações, de se reduzirem os custos políticos, de se definirem e protegerem direitos de propriedade, de se realçar a cooperação, de se internalizarem os custos sociais de externalidades negativas e, de se patrocinarem e promoverem padrões de serviços.

Além disso, quando falarmos de cooperação espontânea, devemos manter em mente que a utilidade dela aos Municípios se baseia na avaliação que os indivíduos fazem de sua capacidade de obter melhores resultados com ela, do que com os respectivos sistemas autônomos. E, quando falarmos de cooperação induzida, devemos manter em mente que a sua estrutura visa otimizar a distribuição de seus recursos voltados à política pública de saúde numa dada região. Portanto, em razão de a 
possibilidade da cooperação também poder ser espontânea, o SUS pode pretender introduzir inovações, empreender investimentos e promover estímulos que mudem as funções preferência das elites políticas municipais na direção da cooperação e do investimento. Seria um aspecto a se confirmar ao longo deste trabalho.

Afinal, conceitos como cooperação e investimento se relacionam com a busca da eficiência e da expansão da capacidade prestadora de serviço. Por outro lado, também se relacionam com conceitos de economia da informação aplicados às mudanças institucionais possíveis de ocorrerem em organizações como o SUS. E, por isso, novamente devemos manter em mente que as informações não estão naturalmente agregadas para as tomadas de decisões, pelo contrário, estão dispersas em múltiplos conhecimentos individuais e incompletos e, às vezes, contraditórios.

Portanto, uma organização como o SUS deve buscar uma forma de agregar a informação dispersa. Embora, nada garanta que um planejador central possa concentrar plena informação, possa reter pleno conhecimento sobre todas as preferências individuais e sobre todas as tecnologias de produção, e, portanto, nada garante que esse planejador centralizado realoque recursos de modo a que todos os indivíduos estejam melhores do que estariam se os Municípios buscassem seus equilíbrios isoladamente.

Focando também a questão nas estruturas de cooperação espontâneas, encontramos os consórcios intermunicipais de saúde, entes supra-municipais que fornecem serviços complementares. Em geral, são estruturados como organizações privadas financiadas por fundos públicos definidos em cotas fixas e administradas por critérios de uso. É por isso que, dados os comportamentos oportunísticos, se faz necessário analisar a estrutura de governança dessas estruturas de cooperação.

Porém, para que uma cooperação intermunicipal seja espontânea e crível, admitiremos como necessário que as regras que regulamentam a qualidade e o acesso ao serviço prestado formem um conjunto "auto coercitivo" a fim de se minimizarem as aventuras contratuais, ou seja, o oportunismo de alguns Municípios aderirem com a expectativa de se comportarem como "caronistas".

Além disso, deveremos evidenciar os mecanismos que confiram credibilidade "ex-ante" ao comprometimento dos Municípios com o financiamento dessa estrutura. Por isso, será importante a análise das relações políticas entre os Municípios a partir 
dos contratos firmados, da forma assumida por essa "arquitetura contratual" e dos mecanismos de "coerção" conferidos por todos os envolvidos a essa estrutura.

Por outro lado, essa estrutura de governança tem um paradoxo: um administrador, a coalizão, monitorando o comportamento de seus próprios patrões, os Municípios. Dado esse paradoxo, recorremos à literatura aplicada a franchising, identificando nas relações existentes os "riscos contratuais", e as suas implicações em termos de criação e de governança de uma estrutura espontânea de cooperação.

Finalizando, a estrutura deste trabalho está apoiada no trato do tema proposto a partir de quatro enfoques teóricos, um em cada capítulo. O primeiro abordará a aplicabilidade da teoria tradicional de finanças públicas ao tema proposto. O segundo buscará desenhar as motivações a comportamentos cooperativos, apoiado, principalmente, na teoria da escolha coletiva e na literatura aplicada à integração européia.

Quanto ao terceiro capítulo, apoiado na teoria dos contratos e na literatura aplicada à franshising, procurará tecer algumas considerações sobre a estruturação da cooperação, em especial a espontânea, tendo por "pano de fundo" o Consórcio Intermunicipal de Saúde de Penápolis, o primeiro constituído no Brasil. Por fim, o quarto capítulo que, apoiado na economia institucional, buscará explicar o comportamento da União, por meio do SUS, como um ente indutor à cooperação intermunicipal. 


\section{CAPÍTULO I}

\section{A TEORIA TRADICIONAL DE FINANÇAS PÚBLICAS APLICADA À COOPERAÇÃO INTERMUNICIPAL}

\section{1. apresentação}

O estudo da cooperação intermunicipal traz uma questão básica: como é possível induzir a cooperação entre os Municípios em um ambiente ${ }^{7}$ federativo? Para o estudo dessa questão, a teria econômica nos disponibiliza alguns instrumentos de análise, sendo, por conseqüência também importante, a definição de qual deles seria o mais adequado, tendo em vista alguns aspectos que devem ser levados em conta. Um desses aspectos é o próprio pacto federativo que, entre outras características, municipaliza a responsabilidade da prestação de serviços públicos de saúde com impacto nos orçamentos públicos. Esta descentralização depende crucialmente do

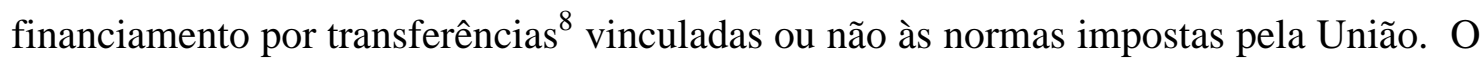
outro aspecto é a externalidade observada nesse setor, que além de acentuada, tem seu monitoramento limitado pela regra constitucional da universalidade do acesso.

Uma primeira ferramenta teórica para a análise da cooperação intermunicipal vem da teoria tradicional de finanças públicas, com foco na teoria de federalismo fiscal. O objetivo seria analisarmos se Municípios suficientemente próximos poderiam ser

\footnotetext{
${ }^{7}$ No mundo real, o setor público consiste de um conjunto de instituições voltadas aos programas de gastos e receitas fiscais, elaborados e aplicados dentro de determinados ambientes políticos. O ambiente federal brasileiro se estrutura em vários níveis de governo, com suas responsabilidades fiscais definidas em jurisdições geográficas pelo contrato constitucional; estabelecendo a alocação das funções entre os diferentes níveis de governo; e, comprometendo verticalmente as diversas esferas federativas com responsabilidades e instrumentos tributários específicos a cada uma delas. Em razão disso, a regra constitucional distribui competências tributárias próprias entre os entes federativos; prevendo-se, nessa estrutura, as transferências financeiras intergovernamentais.

${ }^{8}$ Por outro lado, nem sempre as transferências financeiras são motivadas por algum comprometimento com uma determinada política pública. Dessa forma, os efeitos esperados dos programas de transferências financeiras podem ser diferentes da intenção original, à medida que os Estados e, em especial os Municípios, adquirirem maiores poderes de definir suas especificidades e as prioridades de
} 
induzidos à cooperação, ainda que envolvidos em um federalismo competitivo; embora, cientes de que os Municípios teriam pouca disposição a cooperar se envolvidos em uma "guerra ${ }^{9}$ fiscal" por meio de suas respectivas políticas de alíquotas tributárias.

Assim sendo, procuraremos neste capítulo analisar o federalismo fiscal a partir de uma visão normativa ${ }^{10}$ da teoria tradicional, tentando adaptá-la ao ente municipal, que além de possuir uma estrutura tributária própria, também é receptor líquido de transferências financeiras vinculadas ou não. Acreditamos que a União poderia com as transferências, influenciar a eficiência distributiva horizontal e a existência de internalização de externalidades.

Assim sendo, trataremos de cooperação intermunicipal nos concentrando em questões horizontais, tais como: externalidades, competição ${ }^{11}$ tributária, transbordamento dos benefícios de despesas públicas de um dado Município em outro, ou ainda, nos problemas de exportação tributária quando algum Município procura demonstrar poder de monopólio regional.

No decorrer desta análise, a mobilidade dos indivíduos e dos fatores de produção de serviços de saúde pública terão relevância a partir do modelo de Tiebout, onde um indivíduo revela o padrão de serviço desejado em pelo menos duas situações, uma delas sem qualquer restrição orçamentária, e na outra a sua mobilidade é restringida por um dado custo de transporte. Evidentemente, a mobilidade tem

seus respectivos orçamentos, podendo, inclusive, comprometer os efeitos pretendidos de políticas traçadas a nível nacional pela União.

9 Entende-se instalada a "guerra fiscal" quando a decisão de um dado Município referente à sua política de alíquota tributária é retalhada por algum outro que se considere prejudicado.

${ }^{10} \mathrm{O}$ conceito de enfoque normativo advindo da teoria tradicional surge em contraste com o enfoque contratualista advindo da teoria dos contratos, a qual será abordada nos capítulos seguintes.

${ }^{11}$ Neste capítulo analisaremos a competição tributária sob ótica do federalismo fiscal, e, portento, incorporando o conceito de autonomia tributaria. Isso significa que dizer que cada Município tem a capacidade de administrar com independência (não cooperativamente) seu tributo ou mesmo suas políticas de subsídio para maximizar o bem-estar de seus indivíduos, afetando o tamanho da base tributária disponível e a capacidade de oferta de serviços de outros Municípios vizinhos. Além disso, em meio a ações não cooperativas tributárias, ocorre outra competição tributária: a que disputa maior participação nas transferências financeiras, como as que decorrem dos termos regulamentadores da política publica de saúde da União. 
influência na competição tributária ${ }^{12}$, e esta por sua vez, influiria nas interações dos diversos entes federativos envolvidos, inclusive a União.

Se a competição tributária representa um comportamento não cooperativo dos Municípios, então poderá ser necessária alguma política regulamentadora da União; o que correlaciona nossa questão central, a cooperação intermunicipal, com a definição de Musgrave das funções econômicas de um estado, aplicadas a uma cooperação consolidada em uma coalizão intermunicipal. Fica também inevitável um confronto das idéias de Musgrave com as de Tiebout.

Um outro enfoque dentro da teoria do federalismo fiscal é a questão descentralização "versus" centralização. A favor da centralização, a teoria apresenta as economias de escala na produção serviços públicos de saúde, desde que o ganho de eficiência se dê na proporção em que ocorra pouca variação intermunicipal no padrão de serviços demandados. Caso contrário, poderá haver Municípios com custos de oferta excedendo os benefícios, e, conseqüentemente "transbordamentos", uma situação na qual alguns Municípios serão "receptores líquidos" de serviços de saúde em relação a outro.

Como argumento favorável à descentralização no sentido dos Municípios, esta proporcionaria ao sistema de saúde pública informações melhores que as obtidas pela União, sobre a quantidade e a qualidade dos serviços necessários; ocasionando maior eficiência distributiva em razão de diferenças de preferências e de renda, e, um melhor tratamento tributário da mobilidade dos fatores e indivíduos.

Por fim, definimos a existência de pelo menos dois ambientes, onde procuraremos explicar a cooperação intermunicipal a partir da teoria tradicional de finanças públicas. Denominamos esses ambientes como os mundos de Musgrave e de Tiebout. Entende-se pelo mundo Musgrave, aquele que, apesar da existência de outros níveis federativos além da União, apresente uma forte tendência a atribuir unicamente à

\footnotetext{
${ }^{12}$ A competição tributária pode ser definida em dois tipos: vertical e horizontal. No caso vertical, têm-se tipos distinto de entes federativos competindo pela mesma base tributária, e, em geral, com sobreposição jurisdicional. Já a horizontal, entes federativos de mesmo tipo competem pela mesma base tributária, só que, não há a sobreposição jurisdicional. E, o que se observa nos Estados Unidos são os dois casos, enquanto que no Brasil, é observável a competição horizontal. Daí, novamente mostra-se crucial, mais no Brasil do que lá, que se teçam considerações sobre o grau de mobilidade dos fatores de produção desses serviços.
} 
União a eficiência no exercício das funções de governo: estabilização, distribuição e alocação, principalmente, as duas primeiras; mas, nele admitem-se interações verticais entre a União e Municípios por meio das transferências financeiras. Por outro lado, o mundo de Tiebout considera a existência apenas dos Municípios; além de desconsiderar quaisquer interações entre eles.

\section{2. desenhando os mundos de Musgrave e Tiebout}

Considerando que o mundo de Musgrave dificilmente deixa de contemplar apenas um nível decisório, nosso desafio nesta seção é como essas mesmas funções poderiam ser consideradas numa estrutura voltada à política pública de saúde e formada por dois níveis, os Municípios e a União. Para então, a seguir, nos envolvermos com as diferenças entre os mundos de Musgrave e Tiebout; considerando então, o papel atribuído constitucionalmente à União de normatizar as políticas públicas conforme se faça possível dividir as funções de governos com os outros entes federativos.

\section{1. as funções de governo do mundo de Musgrave}

Sob a ótica do mundo de Musgrave (1959), para a teoria tradicional de finanças públicas, as funções de um governo são denominadas por alocação e redistribuição.

Há uma terceira função: estabilização. No entanto, é senso comum que a política monetária deva estar centralizada na União; embora, choques macro econômicos possam requerer uma resposta coordenada dos Municípios a nível regional. Porém, ainda assim, seria inócua qualquer abordagem da função estabilização, enquanto referenciada à política monetária, como desempenhada pelos Municípios.

\subsection{1. a função alocação}


De modo geral, as externalidades têm justificado a intervenção governamental, inclusive, com o uso de subsídios. No entanto, elas não são suficientemente amplas para justificar a centralização da política de saúde pública na forma do enfoque tradicional pigouviano. De fato, embora essa política pública tenha suas regras gerais centralizadas pela União, a sua execução é descentralizada; e, embora muitos dos programas de saúde pública se originam na União, pouco tem do envolvimento direto desta na oferta ao indivíduo alvo.

Antes, pelo contrário, programas empreendidos pela União partem do princípio de que as soluções serão implementadas diretamente pelos Municípios, independente de quaisquer considerações a respeito das externalidades regionais.

No entanto, se focarmos na questão alocativa desses programas quando aplicada ao nível municipal, acabamos observando os problemas agravarem-se à medida que a regulamentação da União conduza a uma alocação ineficiente da parcela de recursos financeiros voltada ao setor público em foco.

Portanto, resulta dessa discussão, o seguinte argumento a favor da cooperação: a possibilidade dos Municípios, com maior eficiência, monitorarem e administrarem as externalidades, ampliando-se os benefícios, ou mesmo, diminuindo-se os custos associados com a otimização dos recursos voltados ao setor de saúde pública na região por meio da cooperação intermunicipal.

Uma das razões pela centralização da regulamentação do setor de saúde pública na União é o risco de que diferentes Municípios venham a competir entre si pela redução dos gastos nesse setor. A razão está na diversidade de resultados por Município, dadas as diferentes condições sociais encontradas neles, o que provoca diferenças na prestação e na qualidade do serviço prestado, e acirra a competição intermunicipal pela redução dos custos desse serviço. Dessa forma, o argumento da externalidade age como uma chamada à centralização da regulamentação do setor de saúde pública na União.

Por outro lado, o argumento acima pode ser alterado com algumas considerações político-econômicas. Se a regulamentação da saúde pública centralizada na União for por demais excessiva quando aplicada em um ambiente em que as 
externalidades pouco influem ${ }^{13}$ na estruturação de políticas públicas, então ela poderá ser "capturada" pelos entes regulamentados, os Municípios, os quais procurarão “afrouxar" suas restrições via negociação política com a União, debilitando a credibilidade da regulamentação centralizada.

Porém, se esperarmos que os efeitos da competição intermunicipal sobre a prestação de serviços públicos de saúde sejam administrados pelos Municípios, então, estes, provavelmente, procurariam na União, o ente supramunicipal com poder de decisão para regulamentá-los à cooperação, como solução a seus problemas de externalidades no setor de saúde pública.

Até por que, com essa atribuição, também se ampliam tanto o aproveitamento dos recursos existentes na região, quanto a capacidade dos Municípios em atender às regulamentações impostas ao setor pela União, na medida em que a regulamentação da União se mantenha colada às necessidades dos indivíduos da região.

\subsection{2. a função redistribuição}

O tradicional enfoque de finanças públicas recomenda a centralização da redistribuição, um conceito que visa reduzir as diferenças de renda existentes entre pessoas ou grupos, baseada em duas considerações. A primeira é a necessidade de uma ampla base tributária. E a segunda, é a internalização das externalidades e, portanto, dos efeitos ${ }^{14}$ dessas bases tributárias; evitando-se a prática de alíquotas tributárias ineficientemente baixas de uma competição tributária intermunicipal.

No momento, nos abstrairemos das implicações da prática de políticas de alíquotas tributárias quando conjugada com os aspectos redistributivos a nível municipal; até por que, ao se falar em programas de redistribuição regional sob responsabilidade dos Municípios, de imediato surge o temor da perda de suas

\footnotetext{
${ }^{13}$ Ou seja, de baixo grau de mobilidade de indivíduos e de fatores de produção.

${ }^{14}$ Observe-se que esses efeitos se agravam em áreas metropolitanas devido a uma maior mobilidade dos indivíduos e dos fatores, em razão da proximidade geográfica dos Municípios.
} 
identidades jurisdicionais, a partir do qual lhes é negada qualquer atribuição distributivista, mesmo que restrita a um setor da atividade publica.

Portanto, se os Municípios não são um fórum legítimo para atuar, ainda que dentro de uma restrita competência delegada, pode-se esperar a não credibilidade das políticas de redistribuição propostas por eles. Além disso, a propensão a delegar capacidade de tomada de decisão aos Municípios se reduz com o aumento da competição intermunicipal na região, ou seja, com o aumento das externalidades.

Além disso, os Municípios também temem que qualquer processo de redistribuição centralizada por eles mesmos coloque em movimento um processo ${ }^{15}$ difícil de ser controlado, na medida em que não disponham de garantias constitucionais que garantam meios de reação à ineficiência desse processo.

Uma outra razão para esse temor com a centralização de decisões distributivas nos Municípios está nas desigualdades sociais entre eles. Essas desigualdades ampliam a necessidade de uma redistribuição na região, que passa necessariamente pela participação de alguns Municípios como “doadores líquidos” aos demais.

Também é interessante notar que o medo de expansão dos programas redistributivos atribuídos aos Municípios se reduz com o baixo grau de mobilidade dos indivíduos ${ }^{16}$, pois há uma redução das externalidades, e, portanto, uma redução da quantidade dos serviços prestados pelo Município "doador líquido".

Por outro lado, até em razão da universalidade do acesso ao serviço público de saúde, a União não conseguiria prever um programa de redistribuição que distinga previamente os indivíduos que vão demandar serviços da rede pública de saúde, daqueles ${ }^{17}$ que pretendam se abster da posição de tomadores desses serviços públicos.

\footnotetext{
${ }^{15}$ Por exemplo, uma excessiva redistribuição de renda por meio dos serviços de saúde pública prestados por ela.

${ }^{16}$ No entanto, tal hipótese, consiste num paradoxo, pois, qualquer mobilização dos Municípios em prol da cooperação intermunicipal para a prestação de serviços públicos de saúde não pode prescindir das considerações quanto ao grau de mobilidade dos indivíduos da região.

${ }^{17}$ A exemplo daqueles que fazem parte da faixa de renda mais alta e, portanto, com maior capacidade de escolha, envolvendo as redes privadas de saúde.
} 
Essa condição torna os programas de redistribuição mais eficientes na medida em que sejam desenvolvidos mais próximos dos indivíduos.

Além disso, enquanto desenvolvido pela União, a dimensão dos programas de redistribuição acaba quase sempre representando a necessidade de um indivíduo padrão, e, por conseqüência, a aplicação desse programa quase sempre é "per capita". Se o individuo padrão for tomado a nível nacional, o "per capita" seria em razão da população nacional; da mesma forma que, se esse indivíduo padrão for tomado a nível regional, a definição do "per capita" de aplicação seria também sobre a população regional. Aparentemente, se a União pudesse desenvolver seus programas de redistribuição a nível municipal, sua aplicação e possíveis resultados tenderiam a ser mais eficientes.

Essas considerações de eficiência redistributiva proporcional à proximidade de seu público alvo, nos induziria a avaliar a atribuição dos aspectos redistributivos aos Municípios observando, neste caso, como a redistribuição da prestação de serviços públicos de saúde poderia afetar o perfil de distribuição de renda de um dado Município em relação aos outros perfis.

Ou seja, devemos considerar como as diferenças observadas nos perfis de distribuição de renda entre os Municípios implicam que eles necessitem de diferentes padrões de serviços de saúde pública; e, portanto, com diferentes tendências a aceitar um mesmo programa de redistribuição aplicado regionalmente ao setor de saúde publica.

Por esse enfoque, a mesma ineficiência da centralização das políticas de redistribuição na União, também poderia ser observada com a sua atribuição aos Municípios, na medida em que haja a necessidade de se acomodar interesses de alguns Municípios a favor de mais redistribuição regional, enquanto outros temam arcar com uma excessiva redistribuição.

Porém, se fosse possível administrar o grau de mobilidade dos indivíduos, e, lhes fosse possível assegurar o direito de demandar serviços de saúde em outro Município que não o de sua residência, então tais diferenças entre os Municípios poderiam diminuir, o que facilitaria a produção de uma política redistributiva regional 
mais fácil de ser implementada, mas, por outro lado, ampliaria as externalidades regionais.

Uma outra preocupação com a eficiência das políticas redistributivas atribuídas aos Municípios é a que se refere a eles assumirem as políticas de longo prazo de redistribuição de risco $^{18}$. Se da mesma forma que a condução das políticas de alíquotas tributárias é atribuída aos respectivos Municípios envolvidos em razão da maior eficiência, também devemos atribuir os programas de longo prazo à União, pois, é ela dentre os entes federativos, aquele que tem maior capacidade de diluir os riscos.

\section{2. os gastos e receitas públicas em Musgrave e Tiebout}

A questão da cooperação agora se volta para o tema "gasto x receita" em meio a discussões sobre política físcal e orçamento público, onde encontramos Musgrave (1981) preocupado com o equilíbrio fiscal de uma estrutura tributária quando sugere que os tributos progressivos, em geral com propósitos redistributivos, devam ser centralizados a fim de se evitar perversos incentivos à migração entre jurisdições, e, portanto, à ampliação das externalidades.

Musgrave baseia essa diretriz na idéia de que os Estados e Municípios devam evitar as bases tributárias, que em razão de sua mobilidade, distorçam os padrões de atividade econômica, atribuindo à União a competência de atuar sobre elas.

Musgrave (1983) também defende que os Municípios, por estarem próximos aos indivíduos, têm uma certa "pré-disposição" a expandir os níveis de gastos públicos. Além disso, eles também minimizam a necessidade de uma estrutura tributária que

\footnotetext{
${ }^{18}$ A União centraliza o seguro social e a saúde pública, até por uma questão de otimização. Essa otimização instrumentaliza-se com um projeto de transferências financeiras que se aplica a uma área geográfica a mais ampla possível, podendo ser nacional, reduzindo o risco, e, envolvendo o maior número possível de Municípios. Isso evidencia na União uma maior capacidade de diluir o risco que os Municípios, e, portanto, de minorar o custo incorrido. Além do mais, os Municípios não podem garantir desencaixes não previstos com empréstimos, dada a legislação de responsabilidade fiscal. Um outro argumento é a ampliação do risco político dos municípios, pois, exige um projeto de longo prazo imerso em possíveis variações de "humor político" entre eles. Ou seja, a centralização da gestão de divisão de risco na União traz uma "acomodação" político-regional no setor, e, portanto, um menor risco político.
} 
restrinja as externalidades e as ineficiências; até porque, as respectivas administrações tributárias são estruturadas pelos próprios Municípios.

O interessante é que antes disso, o mundo de Musgrave ${ }^{19}$ já considerava o trabalho de Tiebout (1956), reconhecendo que no desenho de uma estrutura tributária se deva incorporar os sinais emitidos pelos indivíduos em função dos níveis de serviço por eles desejados. Dessa forma, por diferentes enfoques, ambos se preocupam com o equilíbrio fiscal.

O mundo de Tiebout dispõe os Municípios como que associados a "lojas" de um grande shopping center; e, atribui ampla mobilidade aos indivíduos, capacitando-os a escolher onde demandar o serviço desejado. Também considera cada Município se comportando como um "comprador" licitando isoladamente os serviços que pretenda ofertar. A quantidade ofertada seria correspondente à soma das demandas individuais; a qual, uma vez agregada, revelaria as reais preferências dos indivíduos como um todo.

Contrapondo-se ao mundo de Tiebout, segundo o qual as preferências individuais por serviços públicos poderiam ser reveladas num mercado, Musgrave (1959) se manifesta da seguinte forma: "No caso da satisfação das necessidades sociais, este raciocínio não se mantém. Os serviços supridos não estão sujeitos ao principio de exclusão. Os consumidores poderão obter os benefícios, quer contribuam, quer não”.

De qualquer forma, um Município no mundo de Tiebout busca atender às preferências de seus indivíduos pela prestação de serviço público de saúde, definindo ${ }^{20}$ um tamanho ótimo em razão do número de indivíduos que optam ali residir.

Por outro lado, poderíamos estender esse mundo de Tiebout para a situação em que a oferta de serviço se dê em uma situação inferior à ótima. Se admitirmos que essa escassez ${ }^{21}$ é percebida por todos os indivíduos demandantes, então, estaríamos

\footnotetext{
${ }^{19}$ Musgrave (1959), capítulo 60, "Determinação Orçamentária por Votação”.

${ }^{20}$ O serviço público de saúde seria fornecido pelo menor custo médio (similar ao ponto mais baixo de uma curva de custo médio da firma). No entanto, faz-se necessário que algum fator ou recurso seja fixado, para se determinar o tamanho do Município e limitar a possibilidade de este serviço se reproduzir em outros Municípios.

21 Admite-se uma limitação física qualquer na oferta dos serviços públicos de saúde.
} 
provocando uma externalidade e induzindo uma parcela desses indivíduos a procurar pelo próximo melhor serviço substituto de saúde pública, como se buscasse uma solução de mercado.

Ou seja, mesmo que algum indivíduo encontre um outro serviço público com padrões apenas próximos aos desejáveis de gastos e receitas, ainda assim, será possível um novo equilíbrio. Porém, o nível agregado de satisfação estará afastado do ótimo.

Como conseqüência, os Municípios com demanda por serviços públicos de saúde abaixo do tamanho ótimo instalado tendem a aceitar o acesso de indivíduos de outros Municípios, principalmente se puderem viabilizar a redução de seus custos médios. Se a demanda estiver compatível com o tamanho ótimo instalado, procurarão mantê-la. E, se acima do tamanho ótimo instalado, seria esperado alguma oposição a incrementos de demanda provocada por indivíduos de outro Município.

Fica-nos obvio que o "não equilíbrio" no mundo de Tiebout implica que existe um grupo de indivíduos descontentes; os quais, dada a hipótese da mobilidade, devem deslocar-se dos Municípios com demanda por serviços públicos de saúde acima do tamanho ótimo instalado, para aqueles com baixa demanda relativa, a fim de satisfazerem da melhor forma possível os seus padrões de consumo. A idéia aqui é a de um movimento espontâneo em reflexo às expectativas dos indivíduos; que, além de revelar a demanda pelo serviço de saúde, também define para um dado Município o seu padrão de receitas e gastos públicos.

Observe-se que no mundo de Tiebout, os Municípios não têm incentivos a se adaptar às preferências dos indivíduos, inclusive, nem se prevê a existência de externalidades. Ao invés disso, tendem a atrair o número ótimo de indivíduos, ou seja, incentivam a adaptação da demanda por serviços públicos de saúde aos moldes de um sistema econômico, com os indivíduos deslocando-se aos Municípios onde o padrão de serviços de saúde pública melhor se ajuste às suas expectativas, com os Municípios "comprando" serviços para ofertar ${ }^{22}$ aos indivíduos de tal modo que, a alocação desses recursos seja eficiente à medida que não haja insatisfeitos.

\footnotetext{
22 Abrindo um parêntese, no mundo Tiebout não existem restrições orçamentárias. E, seja qual for a estrutura tributária que se pense, as restrições orçamentárias dos Municípios brasileiros se agravam pelo descompasso entre os recursos fiscais próprios e as responsabilidades constitucionais; embora, o atual
} 
Enquanto o mundo de Musgrave apenas considera os gastos públicos da União, o mundo de Tiebout se preocupa com os gastos em serviços próximos ao indivíduo, sendo, portanto, muito mais eficientes os Municípios, do que a União, na provisão dos serviços. Esta constatação justifica aos Municípios a capacidade de gestão autônoma atribuída constitucionalmente.

A partir desses argumentos, podemos fazer a seguinte crítica aos dois mundos, o de Musgrave e o de Tiebout: ambos tratam somente do lado da oferta de serviço público. Esses mundos, aparentemente, pouco dependem da definição dos gastos públicos aplicados à provisão da quantidade necessária de serviços públicos a ser ofertada aos indivíduos.

$\mathrm{Na}$ verdade, Tiebout apenas correlaciona o "preço" do bem ou serviço público ao seu custo marginal, a fim de possibilitar aos Municípios debitar a seus residentes um tributo "per capita" igual ao custo de um serviço adicional. Ele também assume que os custos variáveis são constantes, e, assim sendo, fica "à vontade" para definir os indivíduos como "compradores" de serviços públicos municipais como que inseridos em um mercado privado.

Enquanto isso, no mundo de Musgrave, o custo adicional de um indivíduo demandar um serviço público é tido constante, o que implica que, se dobrarmos a população, dobra-se o volume de serviços. Tal hipótese cria uma nova "ponte" com o mundo de Tiebout, pois, em assim sendo, se o número de Municípios que prestam serviços de saúde pública no mundo de Musgrave for grande, todos ofertando diferentes padrões de serviços, então todos os indivíduos revelariam suas preferências movendose para aquele que mais os satisfazem; indicando desta forma, a alocação ótima dos recursos.

Portanto, em ambos os mundos, também a soma das demandas por serviços públicos de saúde em uma determinada região seria a somatória das demandas municipais, tal qual, a que seria determinada pelas forças normais de mercado. A diferença é que no mundo de Tiebout, o critério de escolha dos indivíduos se restringe à adequação entre os padrões de serviços ofertados com o desejado pelo indivíduo.

pacto federativo prevê uma complementação tributária na forma de transferências financeiras intergovernamentais, vinculadas ou não. 
Além disso, os indivíduos no mundo de Tiebout têm um comportamento racional, ainda que se lhes atribuam decisões que revelam suas preferências em um mercado. Afinal, é como se eles fossem à "compra" de um serviço de saúde pública, "cotando preços" entre os Municípios que ofertam os pacotes fiscais que lhe são mais atrativos. O individuo assim procede observando o padrão desejado de serviço público, pois, racionalmente, tenderia a conjugar altos níveis de serviços de saúde pública com baixos tributos.

Um outro tópico a se tratar é como os Municípios financiam a prestação de serviços de saúde pública a partir de suas funções de produção. Para isso, embora o mundo de Musgrave (1983) dê importância à descentralização por efeito alocativo, nós começamos esta análise pelo mundo de Tiebout que trata da mesma função alocativa atribuindo a um indivíduo a mobilidade necessária, e, portanto, a "capacidade" de selecionar aquele Município que lhe proporcione um padrão de serviços adaptado às suas preferências.

Antes disso, observe-se que no mundo de Tiebout não há fricções ${ }^{23}$ na mobilidade do indivíduo. Tal condição deixa implícita que a mobilidade dos indivíduos conduz à homogeneização da composição do tecido social dos Municípios, e, à uniformização do padrão dos serviços públicos de saúde. Assim sendo, em regiões de alto grau de mobilidade as variações do padrão tendem a serem menores dentro do Município do que entre eles.

Ou seja, no mundo de Tiebout em equilíbrio não há Municípios com populações heterogêneas. Isso teria um impacto no padrão de serviços ofertados. A tecnologia de produção no mundo de Tiebout seria especializada, voltada às especificidades de um dado padrão com pouca diversidade; de tal forma que esse padrão teria uma qualidade alta. Portanto, depreende-se das hipóteses formadoras do mundo de Tiebout, que os impactos nocivos só ocorreriam na medida em que o padrão ofertado por esse Município tivesse que envolver uma maior variação das preferências individuais.

\footnotetext{
${ }^{23}$ Para tanto, Tiebout adota algumas hipóteses para que não ocorram fricções na escolha do indivíduo: a informação plena e que todos os seus rendimentos são auferidos por dividendos.
} 
Além disso, no mundo de Tiebout, pelo lado da oferta, todos os Municípios possuem a mesma função de produção ${ }^{24}$ de serviços públicos, indicando que eles têm as mesmas condições de acessar os mesmos insumos desses serviços ${ }^{25}$; embora não sejam apenas as alterações de custo de provisão de um serviço público de saúde que alteram a quantidade ofertada.

Afinal, se retomarmos a argumentação da função alocativa do mundo de Musgrave sob o enfoque do mundo de Tiebout, veremos que sua eficiência pode se alterar com a incorporação de um custo de transporte no deslocamento entre os Municípios, na medida em que este custo afete o grau de mobilidade dos indivíduos e fatores. Além disso, as condições alocativas também seriam afetadas pela variação da alíquota tributária, dependendo do grau de mobilidade de alguns indivíduos ${ }^{26}$ indiferentes à prestação de serviços públicos de saúde.

Além disso, se considerarmos esses serviços sob o enfoque regional, envolvendo vários Municípios, a capacidade de mobilização dos indivíduos também afetaria sua alocação de recursos. É como se tivéssemos os indivíduos fazendo-se conhecerem suas necessidades de demanda pelo serviço aos Municípios, levando-os a avaliarem seus recursos disponíveis, a desenvolverem novas técnicas de produção de

\footnotetext{
24 Oates (1998) se manifesta sobre este assunto, da seguinte forma: “(...) a composição ótima de uma comunidade com algum grau de heterogeneidade suficiente para influenciar na produtividade dos serviços locais, ocorre por meio de um trade-off entre os ganhos da homogeneidade no consumo, tipo Tiebout, com a redução de custos associada a uma produção heterogênea (...)” . Afinal, Tiebout (1956) considera todos os indivíduos "dispostos" a contribuir com um tributo desde que satisfeito o padrão esperado de prestação de serviços públicos de saúde; caso contrário, lembramos de Oates (1998) novamente, quando afirma que “(...) resta a solução por um sistema de equalização por transferências, em meio a um sistema descentralizado”.

${ }^{25}$ Porém, se considerarmos que, para um dado um nível de produção de serviços públicos de saúde, os insumos sofrem variações em critérios de qualidade ou de composição; e, se considerarmos que há diferentes padrões entre os Municípios; então, podemos concluir que, mesmo no mundo de Tiebout, as funções utilidade dos indivíduos poderiam também expressar o nível de qualidade percebida dos serviços ofertados de saúde pública.

26 A indiferença dos indivíduos por um serviço necessário é proporcional às respectivas funções utilidades, que seria percebida nos indivíduos a partir de um processo autuarial. Ou seja, um dado indivíduo em "bom estado" de saúde, aceitaria que ampliassem sua carga tributária para custear a disponibilidade de um serviço público, na medida em que ele considere ampliado o risco em dispensar esse serviço. Dessa forma, os indivíduos tendem a associar o tributo a uma despesa, cujo proveito estaria num futuro incerto, e cuja dimensão é diretamente proporcional a quanto menos otimizada estiver a alocação de recursos no setor de saúde pública.
} 
serviços, e, por consequiência, uma nova alocação ótima. Ou seja, os Municípios deveriam buscar critérios de maximização considerando os seus recursos.

\section{3. a competição tributária intermunicipal}

De acordo com a teoria econômica tradicional, as externalidades geradas pela competição fiscal impõem um ineficiente e baixo nível de tributação e de provisão de serviços públicos. Em razão disso, justifica-se uma coordenação tributária entre os Municípios que evite a competição tributária excessiva; induzindo cada ente municipal a uma maior eficiência arrecadatória sobre suas próprias bases tributárias; e, identificando algumas forças que atuam sobre as alíquotas tributárias quando estas incidem ineficientemente altas sobre as bases móveis.

Encontramos uma dessas forças na própria eficiência com que os Municípios conduzem a arrecadação tributária, quando a correlacionamos inversamente com o volume de evasão fiscal. A outra é reflexo de como as prioridades políticas dos Municípios afetam seus respectivos orçamentos públicos. Por outro lado, a competição fiscal também é útil, a exemplo da redução das alíquotas tributárias a níveis sociais desejáveis, assim como, induz os Municípios a reduzir a síndrome das restrições orçamentárias frouxas por meio da reforma de programas ou empreendimentos ineficientes. De qualquer forma, o objetivo desta seção é o estudo dos efeitos ${ }^{27}$ da competição tributária sobre o equilíbrio das políticas tributárias de uma região.

É possível se identificar algumas perturbações no equilíbrio político entre os Municípios quando, em razão de uma competição tributária, o grau de mobilidade das bases tributárias eleva-se a ponto de afetar a demanda dos indivíduos por serviços públicos de saúde, reduzindo o seu nível de bem estar desejado, na medida que os Municípios reduzam também os gastos fiscais correspondentes.

\footnotetext{
${ }^{27}$ Como observa Wilson (1999), essa “(...) natureza multifacetada da competição no meio dos governos, (...) cria dificuldades no projeto de acordos cooperativos para reduzir os aspectos antieconômicos desta competição. Pode ser possível coordenar uma variável política, mas ao fazer isso se pode simplesmente provocar os governos a competir mais vigorosamente por meio de outra variável política"
} 
Como conseqüência, os indivíduos tendem a aumentar o próprio o grau de mobilidade intermunicipal em defesa de seu bem estar, afetando a produção de serviços públicos de saúde nos Municípios da região. E, os Municípios reagiriam procurando afetar o grau de mobilidade de fatores e de indivíduos, dificultando a adoção de um comportamento cooperativo entre eles.

Além do mais, a competição tributária poderia ter conseqüências redistributivas adversas, que provocariam mudanças relativas nas necessidades de serviços de saúde pública dos Municípios. Ou seja, os efeitos de uma competição tributária entre Municípios, principalmente se em elevado grau, podem desarticular qualquer movimento na direção da integração e da racionalização de um dado serviço público na região.

Uma última observação a ser feita antes de tratarmos da competição tributária mais amiúde, provém do atual pacto federativo brasileiro, no qual existiriam dois vetores atuando sobre as alíquotas tributárias municipais. O vetor das externalidades horizontais fiscais, que tem a sua direção entre os Municípios e o seu sentido está voltado para a redução das alíquotas, enquanto positivamente correlacionadas com a necessidade dos Municípios em ampliar sua base tributária. Encontramos o outro vetor nas externalidades verticais fiscais, que tem sua direção entre Municípios e a União e o seu sentido está voltado para a ampliação das alíquotas, quando positivamente correlacionadas com o volume de participação nas transferências financeiras verticais, vinculadas ou não, a alguma política pública.

Para se ter uma idéia do que isso significa, consideremos que não exista qualquer competição tributaria horizontal entre os Municípios. Então não deveria fazer diferença substancial se os poderes de tributar são atribuídos unicamente à União (com transferências no sentido centro a Municípios) ou se exclusivamente aos Municípios (com transferências no sentido oposto). Se todos os poderes tributários fossem dados à União, então nosso problema se restringiria a uma estrutura tributária de um governo unitário.

Se ao invés disso, eles são atribuídos aos Municípios, então a União pode, atuando como líder federativo, novamente induzir um resultado unitário. No entanto estes pressupostos são uma falácia, pois a mobilidade intermunicipal da base tributaria 
gera inexoravelmente a competição tributária horizontal. Dessa forma, os poderes tributários não podem ser completamente delegados aos Municípios sem arriscar a eficiência distributiva, devendo-se garantir à União suficientes instrumentos tributários para corrigir essa ineficiência. A questão que fica é se essa provisão de serviços pode eficientemente ser maximizada a todos os Municípios de uma região ao mesmo tempo pela União.

\section{1. a "guerra fiscal" intermunicipal travada com as alíquotas tributárias}

É evidente que as bases tributárias concorrentes e próximas criam externalidades fiscais, em razão das alíquotas fixadas pelos Municípios vizinhos. Se considerarmos que a base tributária é completamente móvel, e, que cada Município conhece as alíquotas tributárias e os gastos praticados pelos demais, então, qualquer Município saberia que ao variar sua alíquota tributária, também afetaria a base tributaria dos demais, violando suas restrições orçamentárias, e trazendo com a instabilidade regional, dificuldades de integração das ações de saúde pública com os demais Municípios.

Se essa lógica é correta, então não podemos ignorar a existência da competição horizontal no estudo da cooperação intermunicipal. Afinal, ela afeta a alíquota tributária do vizinho e conduz a região a um outro ponto de equilíbrio com uma alíquota, em geral, inferior à anterior, afetando os gastos em serviços públicos.

Além disso, na ausência de cooperação, cada Município que eleva suas alíquotas ignora quanto de benefício entrega a seus vizinhos, na medida em que induz suas bases tributárias a se mobilizarem na direção do vizinho. Da mesma forma, o Município também ignora quanto de benefício receberia de seus vizinhos se reduzisse a sua alíquota tributária.

Para solucionar a questão relembremos que respeitados os graus de mobilidade dos fatores, se um aumento na alíquota tributária de um dado Município cria uma externalidade positiva em outros; então, o outro Município incorreria em erro se não considerar tais benefícios externos, pois, ao administrar a sua alíquota tributária 
a fim de atrair fatores de outros Municípios, poderá posicioná-la ineficientemente baixa, com a redução na oferta potencial dos serviços de saúde pública.

Uma solução seria a "imposição de limites" à mobilidade dos fatores e indivíduos, de forma que os Municípios dispusessem apenas dos fatores de prestação de serviços que seriam fornecidos pelos indivíduos residentes. Neste caso, as externalidades desaparecem, e cada Município escolheria livremente o seu suprimento de serviços públicos. Por outro lado, não há qualquer restrição, que não econômica, à mobilidade intermunicipal dos indivíduos e dos fatores, o que deve arrefecer qualquer intenção dos Municípios em ampliar os gastos, já que a correspondente elevação de alíquota tributaria para financiá-los traria custos associados com a fuga de base tributária a outros Municípios. Portanto, abre-se espaço a algum tipo de coordenação ou de indução à cooperação entre os Municípios; sugerindo-se esse papel à União a fim de se possibilitar a mitigação da propensão dos Municípios à sub provisão de serviços públicos, em especial, os de saúde.

Porém, ainda permanece o fato de que os Municípios podem escolher diferentes alíquotas tributárias, ofertando diferentes padrões de serviços à medida que seus respectivos indivíduos possuam diferentes preferências ou diferentes dotações de fatores.

Isso poderia induzir os Municípios a uma alocação regional ineficiente dos fatores de produção dos serviços, o que reforça, mais uma vez, que a União atue redistribuindo renda na forma de transferências financeiras a fim de lhe dar com os problemas de maximização do bem-estar do total dos indivíduos dessa região.

Deste modo, a mobilidade dos indivíduos e fatores acaba distorcendo o conceito de otimização que advém da idéia de mercado no mundo de Tiebout, quando essa mobilidade também é induzida pela busca dos Municípios por maiores níveis de participação das transferências em seus orçamentos.

Portanto, temos a União procurando maximizar o bem-estar de todos os indivíduos, ao mesmo tempo em que também procura propiciar a cada Município a capacidade de escolher níveis de oferta eficientes de serviços públicos de saúde, 
conforme se amplia ou não a participação das transferências vinculadas a eles, em seus respectivos orçamentos ${ }^{28}$.

O problema é que a União, quando observa um "cenário de guerra fiscal”, onde há distorções na mobilização intermunicipal de indivíduos e fatores, acaba "se conduzindo" na distribuição com pelo menos dois efeitos. Um primeiro surge de sua atitude como financiador de políticas publicas que distribui recursos de modo mais uniforme e menos eficiente, pois, não se vincula às utilidades dos indivíduos de cada Município da região. O segundo efeito vem da uniformização do critério de distribuição em uma região, que induz alguns Município a sub provisionar serviços de saúde pública, enquanto outros, a sobre provisioná-los, provocando "transbordamentos" na região.

Já observamos em seção anterior que em razão dos Municípios conhecerem mais das necessidades de seus indivíduos que a União, a função alocativa dos recursos é mais eficiente quando efetuada por eles. E, como o foco principal deste estudo é a cooperação intermunicipal, haveria a necessidade de que cada um dos Municípios incorporasse em suas decisões orçamentárias a racionalidade econômica dos ganhos advindos com a cooperação; ainda que eles tendam a elevar o bem-estar só de seus indivíduos residentes. Esses ganhos se consubstanciam na otimização dos recursos existentes regionalmente, evidentemente, desde que o bem estar de seus residentes fosse igual ou maior num ambiente de cooperação regional do que isoladamente.

Agora, para fechar o conceito de competição tributária deflagrada a partir das alíquotas, consideremos os Municípios competindo pela oferta do serviço de saúde na região. Cada um deles contém um número fixo e idêntico de indivíduos residentes, cujas funções utilidades são em razão direta do consumo desse serviço, e, inversa da mobilidade. Os gastos com o serviço público de saúde são financiados por um tributo sobre o consumo desse serviço, uniformemente aplicado onde é ofertado e não vinculado à origem de quem o consumiu. Como resultado, os residentes de um

\footnotetext{
${ }^{28}$ É uma tendência que explica o arrefecimento dos Municípios em financiar gastos em serviços públicos com receita tributária própria, induzindo alguns deles ao "desdém" de praticar alíquotas tributarias relativamente maiores que outros.
} 
Município podem escapar de pagar esse tributo, incorrendo em custos de transporte para consumir no outro Município e ao tributo lá imposto.

De imediato, um primeiro equilíbrio dá-se quando os custos de transporte são tão altos que não ocorre demanda pelo serviço no Município vizinho; não causando externalidades, e, nem a competição intermunicipal porquanto não há necessidade de redução das alíquotas tributarias.

Porém, mesmo nessa situação, a racionalidade dos indivíduos se manifestaria com base na diferença entre as alíquotas tributárias dos Municípios vizinhos e o custo de transporte. Com esse raciocínio, o Município de alíquota tributária mais baixa na região assumiria o papel de "exportador" do serviço publico aos residentes vizinhos. Ou seja, novamente temos a sub provisão do serviço publico tanto no Município “exportador" de serviços por pressão de demanda, quanto no "importador" por redução dos níveis relativos de financiamento enquanto os indivíduos do segundo "escapam" do tributo na origem, demandando no outro, em razão de sua mobilidade.

\section{2. outras formas de competição intermunicipal}

Existem outras formas dos Municípios competirem pelos indivíduos, pelos fatores móveis, e, portanto, pela "compra" de serviços, sem fazerem uso da política de alíquotas tributárias. Uma possibilidade é a competição com programas de subsídios que implementem a produtividade dos fatores. No entanto, os subsídios podem agravar a competição se os Municípios não conseguirem manter equilibrado o perfil dos gastos à provisão dos serviços, gerando a necessidade de se ampliar as receitas publicas.

Outras formas poderiam ocorrer pelo uso de políticas ambientais ineficientes; pelo relaxamento na aplicação de políticas, por meio de legislações tributárias, e, até pelo "blefe". Ou seja, um Município "antecipa" uma política de subsídios para atrair fatores. Se os demais "preverem" a futura elevação do nível de endividamento daquele Município, e, portanto, a futura elevação de sua alíquota tributária, então, os demais Municípios podem decidir ampliar suas respectivas alíquotas tributárias, beneficiando o 
primeiro com a "redução relativa" de sua alíquota tributária, e, reduzindo-lhe a necessidade de ampliar a própria.

\section{3. os aspectos positivos da "guerra fiscal" intermunicipal}

Até aqui, assumimos implicitamente que os níveis de gastos públicos em determinado serviço se mantêm sem grandes variações relativas entre eles, e que os Municípios, até mesmo em razão disso, competem pelas receitas sem qualquer vínculo com seus gastos, à exceção das transferências financeiras vinculadas.

Porém, nesta subseção realçaremos a eficiência encontrada na competição tributária, além da observada até aqui apenas no mundo de Tiebout. Assim sendo, se a necessidade de um determinado gasto público assumir uma maior proporção relativa às outras políticas públicas, a ponto de ser significativo no orçamento publico, então, os Municípios podem competir pela atração de grandes bases tributarias, para irem de encontro à necessidade de financiar maiores gastos, dando-lhes um perfil mais agressivo na condução de sua política fiscal.

É possível nessas circunstancias que os Municípios ofertem subsídios e isenções específicas, ao invés de alterarem os respectivos sistemas de alíquotas tributárias, enquanto represente uma dada redução esperada na receita fiscal. Neste caso, a atração de fatores será eficiente se não criar outros custos aos demais Municípios; ou ainda, se não impuser custos adicionais em serviços e infra-estruturas públicas.

Seguindo essa linha de raciocínio, admitamos que dois Municípios querem sediar um grande hospital de referencia regional; e, portanto, competem por uma grande base tributária. Admitamos que ambos Municípios sabem que a presença desse hospital mobilizaria indivíduos de outros Municípios, e que essa demanda poderia reduzir o custo médio desse serviço aos seus indivíduos residentes, e, assim sendo, 
estabelecem uma competição instrumentalizada não somente por alíquotas tributárias, mas também com os gastos públicos ${ }^{29}$.

Portanto, desconsiderando a eficiência do tributo "per capita" do mundo de Tiebout, suponhamos que cada indivíduo residente pague um tributo equivalente ao custo "per capita" médio de provisão desse serviço, e que esse custo esteja abaixo do custo marginal. Nessa condição, se um Município atrair um grande hospital, ou mesmo, empreender um gasto público em sua instalação, não reduziria a eficiência dessa ação, pois, ao reduzir o custo médio, também reduz o custo marginal da produção do serviço publico.

Por outro lado, mesmo que considerarmos que, além da competição horizontal, temos, conjugadas, as externalidades alterando também a eficiência obtida com a localização deste grande hospital; e, mesmo se admitirmos que a região possua vários Municípios dispostos a competirem entre si por sediar esse hospital em suas respectivas jurisdições; ainda assim, se um desses Municípios conseguir atraí-lo para a região, então todos os demais poderão se beneficiar na forma de preços de serviço mais baixos, devido à redução nos custos de transporte. Ou seja, quando um dos Municípios conseguir "importar" um hospital de referencia regional, acabara criando efeitos-preço desejáveis para os outros.

Por isso, se nós intuíssemos que há uma ação coordenada entre todos os Municípios pela instalação do hospital na região, poder-se-ia instalar um hospital de referência regional com maior facilidade na medida em que a competição entre os Municípios para sediá-lo fosse menos vigorosa em razão da existência de um comportamento cooperativo entre eles voltado à prestação de saúde pública na região. Porém, embora se perceba que os resultados produzidos em ambiente regional

\footnotetext{
${ }^{29}$ Se relaxássemos a hipótese de que os Municípios e os proprietários do hospital detêm plena informação sobre a produtividade do hospital, então os dois Municípios poderiam propor subsídios de atração ineficientes na medida em que o proprietário do hospital detivesse informações privadas não reveladas sobre como os seus custos de prestação diferem entre os dois Municípios. Neste caso, o proprietário escolheria onde se instalar, e os Municípios competiriam entre si propondo subsídios fiscais por meio da redução de alíquotas, por exemplo, que alterariam as relações custo benefício de sua instalação. Por outro lado, esses subsídios poderiam também ser precedidos pela oferta de gastos públicos em "infra-estrutura", então, muito provavelmente, o proprietário do hospital tenderia a instalarse no Município cuja proposta de gasto público fosse a mais alta; embora, dada sua racionalidade econômica, nada o impede de alterar sua decisão diante das propostas de subsídios fiscais.
} 
cooperativo podem ser mais eficientes, ainda permanece a questão de como os vários Municípios poderiam construir essa cooperação.

Além disso, a ineficiência da competição intermunicipal, inclusive a instrumentalizada pelos gastos públicos, pode ser ampliada com a diversidade de ações municipais no setor de saúde pública na região. Como exemplo, consideremos os mesmos dois Municípios, só que desta vez, cada um com o seu hospital já instalado com uma oferta excedente, e, portanto, procurando "exportar" serviços aos demais Município na região; cada um subsidiando os custos de provisão dos serviços médicohospitalares.

Os dois Municípios sabem que os subsídios afetam não só as decisões de produção de serviços do hospital, mas também as decisões de localização dos fatores de produção de serviços hospitalares, os quais têm suficiente mobilidade entre os dois Municípios para se deslocarem na direção de onde "lucros pós-tributo" são mais altos.

Se o objetivo de cada Município é a hegemonia político-regional, então, cada um deles, buscaria atrair os fatores de produção do outro hospital. Portanto, como conseqüência, ambos vão procurar capturar essas bases tributarias sem discriminá-las das próprias, através de alíquotas tributárias cada vez menores, ampliando a ineficiência.

Porém, se os argumentos acima procedem à luz da teoria do federalismo fiscal, então, provavelmente, seria inviável que os Municípios, detentores de informação plena das conseqüências da competição tributária sobre os fatores que produzem os serviços públicos de saúde, adotassem uma postura cooperativa fundada em sua racionalidade econômica ilimitada, construindo uma cooperação intermunicipal na região, a qual, não necessariamente, maximizaria os seus resultados individuais nesse setor.

\section{4. aspectos sobre externalidade e mobilidade}

Segundo autores como Wilson (1999), o modelo de Tiebout (1956) enriquece a teoria econômica tradicional com a possibilidade de a competição tributária ser 
eficiente através da oferta de serviços públicos financiados por tributos locais. No entanto, no mundo de Tiebout, que se assemelha a um mercado competitivo, além de não existir qualquer previsão de transferencias financeiras, os Municípios também não podem alterar as "disponibilidades" previamente ofertadas aos indivíduos para que estes residam neles.

Além disso, o mundo de Tiebout também não prevê qualquer intervenção dos Municípios com a União; enquanto esta procura otimizar a alocação de recursos sem muita eficiência em fazer com que todos os indivíduos de uma região fiquem em melhor situação, sem que ninguém piore em razão disso. Afinal, a União não consegue perceber todas as conseqüências que a competição tributária intermunicipal pode implicar $^{30}$.

De qualquer forma, do mundo de Tiebout pudemos extrair o conceito de mobilidade, utilizado em sua teoria como um mecanismo de revelação das preferências dos indivíduos por um determinado padrão de serviços. O nosso interesse com relação ao conceito de mobilidade, é que o enxergamos como um "canal de comunicação" entre as ações dos Municípios e os efeitos das externalidades provocadas por elas.

Intuímos que os efeitos das ações dos Municípios, em termos de externalidade, seriam diretamente proporcionais ao grau de mobilidade dos indivíduos e fatores. Inclusive, se estes permanecerem inertes ante uma ação dos Municípios, não haveria que se falar em externalidades. Em razão disso, nos concentramos nesta seção na análise das externalidades e da mobilidade a partir do mundo de Tiebout, ou seja, considerando os Municípios e os indivíduos.

Nossa análise principia pela aplicação de uma dada política tributária ao mundo de Tiebout, a partir da qual pudéssemos buscar o equilíbrio com os indivíduos "escolhendo" um Município. O critério de escolha dos indivíduos seria na medida em que o futuro pagamento tributário se equiparasse ao custo de se prover os padrões de

\footnotetext{
${ }^{30}$ Como exemplo, um dado Município, ao aceitar baixos níveis de alíquotas tributárias, acaba também aceitando baixos níveis de receita própria, comprometendo a provisão de serviços públicos, a fim de induzir a mobilidade de indivíduos e fatores em sua direção, a partir da suposição de que esses indivíduos decidem racionalmente maximizar suas preferências.
} 
serviço público disponibilizados e desejados pelo individuo. Note-se que o conceito de mobilidade dos indivíduos para "fazer” essa escolha já está implícito. .

Estando no mundo de Tiebout, podemos assumir que somente a atividade de serviços de saúde pública é tributada, de modo que um Município possa otimizar a oferta de um dado padrão desse serviço a partir de um desempenho tributário competitivo. Ou seja, que o custo per capita de prover uma dada quantidade desse padrão de serviço, a cada indivíduo, não depende do número deles no Município, o que significa dizer que não há economia de escala no consumo deste serviço público.

$\mathrm{E}$, além disso, também podemos assumir que a mobilidade dos indivíduos somente difere entre si pelas respectivas preferências por um padrão de serviço de saúde pública; que os Municípios no equilíbrio oferecem diferentes alíquotas tributárias e níveis de serviços; e, que os indivíduos revelam suas preferências quando escolhem residir em dado Município da região.

De imediato, a partir desse cenário podemos observar que, se uma alteração na alíquota do tributo sobre serviços puder criar uma externalidade, então, podemos entender que nem todos os Municípios perdem com a "guerra fiscal". Ou seja, os indivíduos com preferências relativamente "baixas" por serviços de saúde ficam quase sempre em melhor situação "pós-guerra fiscal", pois, os benefícios de uma "guerra fiscal" quase sempre se vinculam à redução relativa da alíquota tributária sobre serviços, incentivando o influxo de fatores à produção desse serviço. Portanto, como conclusão, temos que a composição da base tributaria afeta a mobilidade dos fatores e dos indivíduos, e, portanto, as externalidades.

Para exemplificar a lógica de como a mobilidade pode influir na preferência dos Municípios sobre qual tipo de base escolher para tributar, é possível se observar que os Municípios, em geral, têm uma predileção ${ }^{31}$ pelo tributo sobre a propriedade

\footnotetext{
${ }^{31}$ Para ilustrar isso, recorremos a uma região metropolitana, onde se deflagra uma "guerra fiscal", na qual, cada Município desenvolve uma estratégia a proteção do valor de sua base tributária fixa: a propriedade imobiliária. Na seqüência, os Municípios vão perceber que a competição pelo tributo sobre imóveis envolve fixar o maior número possível de indivíduos, e, passam a observar as firmas, que além de possuírem imobilizado, demandam mão de obra. Cientes disso, os Municípios escolhem usar o tributo sobre uma base tributária variável para "atrair" as preferências das firmas; ao mesmo tempo em que amplia o a base fixa a partir da firma, de seus funcionários e de seus proprietários.
} 
imobiliária, cujo valor expressaria uma base tributária "cativa" em sua jurisdição, e, portanto, imóvel, ou seja, o mais baixo grau de mobilidade.

Afinal, quando correlacionamos o conceito de "guerra fiscal" com o grau de mobilidade, observamos os Municípios utilizando seus instrumentos tributários voltados a ampliar ou reduzir o grau de mobilidade das bases tributárias, tanto as já situadas em suas jurisdições, quanto aquelas que desejam atrair ou mantê-las fora de suas jurisdições.

De qualquer forma, sob a ótica da teoria tradicional de finanças públicas, podemos definir o esforço do Município de mobilizar uma base tributária como sendo proporcional ao grau de mobilidade intrínseco dos indivíduos e fatores, resultante da individual matriz de decisão custo benefício, imanente da racionalidade econômica.

Além disso, é interessante observar que os mesmos instrumentos tributários usados na "guerra fiscal" para atrair ou repelir bases tributárias, também podem ser utilizados para inferir o seguinte encadeamento lógico: quanto maior é a intensidade do conflito fiscal, menor tende a ser o tributo incidente sobre as bases tributárias variáveis na medida em que os Municípios procurem “compensar" essa perda com o tributo sobre as bases tributárias fixas, sem que isso garanta a não ampliação do risco à sub provisão de serviços públicos em geral.

Agora, retomando do mundo de Tiebout a hipótese de que não há economias de escalas na produção de serviços públicos de saúde, mas, considerando que o tributo que os Municípios incidem sobre a atividade de saúde pública é “per capita”, em relação aos indivíduos residentes, ou seja, não incide sobre indivíduos de outros Municípios. De imediato, se esse valor "per capita" representar o custo marginal de prestar esse serviço, então, poderemos ter o orçamento equilibrado, pois, com a ausência de economias de escala o custo marginal de se prover esse serviço se iguala ao custo "per capita".

No entanto, se essa lógica procede, então, a União poderia intervir numa dada política publica municipal adotando o critério populacional, exercendo sua função redistributiva por meio de transferências financeiras. Afinal, tal qual um tributo "per capita", uma transferência financeira dimensionada em razão de índices populacionais pode induzir um dado Município a escolher um nível mais eficiente de provisão desse 
serviço publico do que o obtido numa "guerra fiscal". Além disso, também haveria um efeito de segunda ordem com a regulação da mobilidade de indivíduos e de fatores.

Por outro lado, se houver economias de escala na produção de serviços públicos, então, um tributo "per capita", ou mesmo, uma transferência financeira por critérios populacionais, pode não mais complementar as necessidades do orçamento público sob a lógica do preço/custo marginal; exigindo um outro tributo, cujo montante corresponda, pelo menos, à diferença entre o custo "per capita" de provisão do serviço público e o seu custo marginal.

No entanto, mesmo que o Município escolha uma base tributária própria ${ }^{32}$ para complementar a necessidade de influxo fiscal no orçamento público, nada garante que o equilíbrio orçamentário só seja obtido com a sub provisão do serviço publico de saúde. A resultante poderia ser, entre outras, a ampliação da competição fiscal e dos efeitos das externalidades.

Afinal, em geral, as "externalidades intermunicipais" são em razão das ações dos Municípios, principalmente as de cunho tributário, que alteram o bem-estar não somente de seus residentes, mas também os de outros Municípios, provocando conseqüências nos respectivos orçamentos públicos. E o interessante é que o mundo de Musgrave, embora preocupado com a natureza teórica da determinação orçamentária, não a vincula às questões de externalidades.

Para exemplo de como ações de política tributária afetam os demais Municípios, consideremos um Município ${ }^{33}$ que decide reduzir suas alíquotas tributárias para atrair fatores de produção, e ampliar sua base tributária. Em razão disso, este dado Município espera um incremento de receita própria a partir de sua intervenção na

\footnotetext{
32 A constituição brasileira de 1988 atribuiu competência aos Municípios sobre dois impostos: territorial e urbano-IPTU, e serviços-ISS.

${ }^{33}$ Nesse exemplo, a externalidade também se manifestaria se esse Município fosse o de maior porte e polarizador econômico, de modo a afetar o produto ou preços de fatores quando confrontado com outros Municípios de sua região de influência, causando um "excesso" de concentração econômica. Um outro tipo de externalidade também poderia surgir como resultado de ineficiências nos mercados privados, em conjunto com o fracasso dos governos em corrigi-las. Além disso, os Municípios podem formatar suas políticas públicas de modo que não se ajustam ao esperado pelos seus residentes, e, com isso, provocar externalidades; ou seja, o fato dos Municípios agirem, não garante que ocorra o deslocamento desejado dos indivíduos, na medida em que este também depende do grau de mobilidade em fazê-lo que é percebida por eles.
} 
política de alíquotas tributárias, a qual será em detrimento de outros Municípios, na medida em que afete negativamente as bases tributárias daqueles, e, portanto, reduza suas receitas.

Um outro exemplo poderia ser desenhado a partir do mesmo Município decidindo ampliar ou reduzir seus gastos em política pública de saúde. Tal decisão poderia afetar a eficiência dos serviços prestados pelos Municípios vizinhos na medida em que os indivíduos pudessem se mobilizar para a satisfação de suas funções utilidade “importando" serviços de outro Município.

Ou ainda, esse mesmo Município poderia ofertar um volume menor de serviços de saúde pública que a que seria necessária, caso seus vizinhos, por exemplo, tivessem um serviço de saúde preventivo adequado ou mesmo possuíssem regulamentações de acesso aos seus serviços prestados menos restritivas que o seu.

Observe-se que esses exemplos, "per si", evidenciam a existência de uma correlação entre os conceitos mobilidade e externalidade, a ponto de presumirmos que a variação entre elas é diretamente proporcional.

Ainda com relação ao conceito mobilidade, há que se fazer uma distinção entre a mobilidade de deslocamento e a mobilidade de migração. Para ilustrar essa diferença, retomemos a hipótese do modelo de Tiebout (1956), de que, na região, todos os indivíduos são plenamente livres para se moverem. Embora a realocação de fatores tenha custos, consideraremos que no equilíbrio, um indivíduo de um dado Município satisfaça seu padrão de consumo de serviços de saúde sem qualquer restrição em revelar sua preferência de onde toma-los, podendo ser do sistema municipal onde reside ou de outro qualquer.

Consideremos que esse indivíduo possa migrar para outro Município ou se deslocar na região de seu Município de residência a um custo equivalente a uma fração infinitesimal do consumo que terá no seu destino, tal que, o seu deslocamento em nada influencia a oferta do serviço. E, admitamos também que ele se move sem ser distinguido pela origem, garantindo-lhe as condições do Município ao qual se dirigiu.

Com essas hipóteses podemos inferir duas conclusões em relação ao indivíduo. A primeira, que ele decidiria migrar a partir de considerações que ele faz sobre a quantidade de consumo que obterá, após considerar o padrão ofertado e os 
tributos incidentes no Município de destino em relação ao de origem. A segunda, que ele decidiria tomar serviços em outro Município, que não o de sua residência, em razão do padrão ofertado em seu Município confrontado com a sua própria necessidade de recursos médico-ambulatoriais colocados à disposição por outro Município.

Independente de se analisar se as externalidades são positivas ou negativas no exemplo acima, o que se observa é que em ambas situações ocorre a ampliação da base tributária no Município de destino. Numa porque a migração ampliou a base tributária fixa no destino (novos fatores de produção), enquanto na outra, o deslocamento ampliou a utilização dos fatores de produção já fixos no destino, ampliando a base tributária variável (renda e movimento econômico).

Por consequiência, ambas as ações tendem a deprimir a receita tributária na origem dos indivíduos. Assim sendo, para a correlação da competição tributária, e, portanto, externalidades, com a mobilidade de indivíduos e fatores consideramos desnecessário no conceito de mobilidade, distinguir-se as situações de migração e deslocamento.

Além disso, infere-se que a dimensão das externalidades deve variar inversamente proporcional à distância geográfica dos Municípios envolvidos; e diretamente proporcional com a diversidade relativa entre as estruturas sócioeconômicas desses Municípios.

$\mathrm{E}$, se a dimensão das externalidades na região, sejam elas positivas ou negativas, for economicamente importante, então pode haver um ganho em potencial de eficiência com a obtenção de um novo equilíbrio na prestação de serviços de saúde pública por meio da internalização dessas externalidades, possível com os Municípios da região otimizando seus recursos em uma ação de mútua cooperação.

No entanto, independente do tipo de mobilidade, o indivíduo também poderia ter limitações em sua capacidade de se mobilizar. Além disso, poderia ter as hipóteses que sustentam o mundo de Tiebout relaxadas, de tal forma que não estivesse perfeitamente informado, e, portanto, não conseguisse maximizar suas preferências entre os vários padrões de serviços ofertados.

É evidente que isso contrariaria a definição do indivíduo do mundo de Tiebout, afinal, o indivíduo nesse deveria estar apto a avaliar a qualidade das 
facilidades e padrões de serviços colocados à disposição pelos Municípios que existem para sua escolha, e confrontar com suas necessidades expressas em sua função utilidade.

Por outro lado, ainda que Tiebout (1956) relate que os Municípios "regionalmenteagregados" podem atender a várias expectativas dos indivíduos, estes, independente do serviço público demandado, já exerceriam a sua escolha desconhecendo a totalidade das opções de padrões municipais de receita e gastos empregues não somente na atividade de saúde pública, mas também em todas as demais atividades públicas.

Afinal de contas, os indivíduos, mesmo os do mundo de Tiebout, não se mobilizariam sem avaliar as razões em fazê-lo. Ou seja, podemos presumir que o mundo de Tiebout também "funciona" com os indivíduos maximizando suas funções de utilidade com as informações de que dispõem.

Assim sendo, poderíamos reler o modelo de Tiebout (1956) substituindo os Municípios por regiões, desde que os Municípios agrupados por regiões justificassem tal releitura com ações cooperadas que resultassem em um determinado ${ }^{34}$ padrão de serviços regional, o qual absorvesse proporcionalmente a diversidade das funções utilidade dos indivíduos na região, de modo a garantir que o serviço de saúde publica seja o esperado por eles.

Além disso, seria necessário que se preservassem os gastos e a quantidade de qualquer serviço prestado por qualquer dos Municípios situados nessa região; ou então, ocorrendo alguma redução agregada de gastos, ainda que motivada pela exclusão de algum dos serviços públicos ofertados, essa redução pudesse se justificar, no mínimo, com a manutenção do bem estar social agregado, aferido a partir da mesma função de bem estar, a qual, é desconhecida.

Assim sendo, resta-nos considerar que um padrão de serviço ofertado regionalmente não poderia ser aceito economicamente se, em qualquer dos Municípios envolvidos, houver uma redução no acesso dos indivíduos ao serviço prestado em relação ao que era prestado anteriormente pelo Município de sua residência.

\footnotetext{
${ }^{34}$ O padrão regional de serviços de saúde pública poderia ser resultante de uma envoltória dos vários padrões municipais de serviços prestados na região.
} 
Note-se que, se assim não o fosse, provavelmente teríamos uma alocação ineficiente dos gastos em serviços públicos de saúde na região, podendo implicar em outras externalidades a partir de políticas de alíquotas dos Municípios, voltadas ao propósito de compensar quaisquer ineficiências alocativas.

E, além disso, dado o grau de mobilidade e de informação dos indivíduos, também haveria implicações sobre o processo de redistribuição na região, principalmente, se as ações regionais não refletirem o esperado pelos indivíduos de algum Município; ou ainda, se os Municípios não conseguirem equalizar as ineficiências resultantes de divergências entre as diversas políticas propostas por eles ao setor de saúde pública.

\section{5. a interação da União e Municípios no federalismo fiscal}

\section{1. a União no federalismo fiscal}

A União pode ser vista como tendo pelo menos dois papéis fiscais: a redistribuição através dos Estados e Municípios da federação, e, a coordenação da internalização das externalidades fiscais em relações horizontais.

No entanto, se a União coordenasse as tomadas de decisões dos Municípios poderia ferir a autonomia constitucional administrativa deles. Por isso, a União reconhece nos Municípios o poder formal de tomada de decisão. A consequiência é que a União acaba restringindo-se aos programas de transferências financeiras para induzir nos Municípios a internalização de externalidades horizontais, compensando os transbordamentos de gastos públicos; para então, direta ou indiretamente, e induzir a cooperação.

De qualquer forma, a União procura trazer o setor de saúde pública tão controlado quanto possível, para ter um resultado favorável próximo do que obteria um agente tomador de decisão centralizador e benevolente. Só que, para isso, a União necessita, no mínimo, acessar às mesmas informações dos Municípios. 
Assim sendo, podemos definir a função objetivo da União voltada à política pública de saúde como a maximização da eficiência nacional na prestação desses serviços, no mínimo, maior ao que seria obtido dos Municípios individualmente. Por trás dessa função objetivo da União estão as hipóteses neo clássicas, em especial, as de racionalidade plena e de informação completa; o que, de certa forma, praticamente justifica a decisão centralizada na União, "dispensando" a participação dos Municípios nesse processo.

A União se caracterizaria, portanto, como uma maximizadora benevolente ${ }^{35}$ do bem-estar agregado de todos os Municípios, da mesma forma que um Município também poderia ser um maximizador do bem-estar de seus residentes.

Não devemos esquecer que a União normatiza a política publica de saúde sem vinculá-la às restrições orçamentárias dos Municípios, até porque, essas restrições são muito diversas entre si. E, se por hipótese isso fosse possível, então seria como se a União e os Municípios estivessem fixando simultaneamente a política pública de saúde, o que simularia um estado centralizado. De qualquer forma, imaginamos que a União encontra sempre uma solução por meio de seus instrumentos de política publica para lhe dar com as ineficiências observadas nos Municípios.

Evidentemente, estamos admitindo que a União pode minimizar os problemas de assimetria de informacional, de coordenação, e até mesmo, de divergência entre as funções objetivo dos Municípios, ainda que voltadas à maximização de bem-estar de seus respectivos residentes.

Além disso, também admitimos que os Municípios, ao decidirem competir por bases tributárias utilizando suas políticas de alíquotas tributarias, justifica à União a atribuição de desfazer quaisquer ineficiências resultantes. Ou seja, admitimos que a

\footnotetext{
35 A situação aqui desenhada revela uma sobreposição de intenções, o que poderia resultar em conflitos, se não fosse a idéia de benevolência atribuída à União, a qual confere à "norma geral" editada pela União a este setor, a característica de vinculada às necessidades dos Municípios em geral, e, portanto, "dispensando-lhes" posturas divergentes. Essas posturas poderiam ser observadas quando os Municípios escolhem suas políticas depois que a União normatiza a política pública de saúde, em atenção ao dispositivo constitucional que lhe outorga a competência de elaborar algumas "normas gerais". Com a elaboração dessa "norma geral" a União normatiza um grau de comprometimento que todos os demais entes federativos deveriam adotar em suas ações voltadas à saúde pública em suas jurisdições. No entanto, o pacto federativo estende aos Municípios o princípio da autonomia federativa, permitindo-lhes adotar uma política pública nesse setor descolada da normatizada pela União.
} 
União pode induzir os Municípios à ampliar a competição pelas transferências financeiras verticais, reduzindo a competição tributária horizontal; e, dessa forma, pré dispô-los à cooperação na medida em que consiga induzi-los a alinharem suas respectivas políticas públicas de saúde a uma única normatização imposta.

\section{2. centralização “versus” descentralização na teoria econômica tradicional}

Neste ponto, é oportuno retomarmos as funções de governo segundo Musgrave (1959), na medida em que este associa a atribuição delas entre os diversos entes federativos com alguns aspectos ligados ao grau de centralização da tomada de decisão. Pudemos desenhar o mundo de Musgrave a partir de sua proposição de que as “(...) políticas do ramo alocação poderiam se permitir diferenciar entre os Estados ${ }^{36}$, dependendo das preferências de seuscidadãos. Osobjetivos dasfunções $\quad$ distribuição $e$ estabilização, entretanto, requerem a responsabilidade principal de um nível central” .

Dessa forma, o mundo de Musgrave admite a descentralização da função alocação e a centralização das funções estabilização ${ }^{37}$ e redistribuição. No entanto, a tomada de decisão concernente à função redistribuição, dependendo do grau de centralização da escolha da política a ser implementada, teria espaço para ser atribuída a um Município a partir de uma política fiscal própria.

Colocando de uma outra forma, a possibilidade dos Municípios dividirem com a União a função de redistribuição por meio da aplicação de políticas de saúde pública seria em razão de um possível equilíbrio entre a atração de indivíduos de outros Municípios, com a "expulsão" daqueles indiferentes à existência de acesso ao serviço de saúde pública, à medida que se ampliam suas resistências a qualquer incremento nos gastos tributários voltados ao setor.

\footnotetext{
${ }^{36}$ No presente contexto, poderíamos entender Estados por Municípios.

37 Até porque, se por hipótese houvesse a descentralização da função estabilização, atribuindo-se aos Municípios um eventual papel contra cíclico aos choques macroeconômicos, em razão de seus impactos diferenciados por região, sempre se faria necessária uma "coordenação compulsória” a partir da União.
} 
A teoria econômica tradicional de finanças públicas tem simplificado a divisão da tomada de decisão considerando que esta se processa em apenas um ente federativo, a União. Embora, vez por outra, "relaxe" essa hipótese, considerando que as decisões possam ser tomadas em diferentes níveis burocráticos desse mesmo nível; o que, de certa forma, é coerente com o mundo de Musgrave, o qual se mantém alheio à existência de diferentes níveis de governo, circunscrevendo as tomadas de decisão em políticas públicas praticamente à União.

Enquanto isso, Tiebout (1956) desenvolve sua teoria, referindo-se aos autores que estudavam a teoria tradicional do federalismo fiscal, como aqueles ${ }^{38}$ que não acreditavam em uma “(...) solução típica de mercado para o nível de gastos fiscais numa provisão ótima de serviços” . E, assim sendo, o mundo de Tiebout surge sob a ótica do mercado, voltado especificamente aos Municípios exercendo a função de governo alocação, admitindo que eles, os Municípios, têm melhor percepção das preferências dos indivíduos do que a União ${ }^{39}$.

Inclusive, Tiebout (1956) idealiza seu indivíduo como alguém escolhendo um serviço entre as "lojas" de um "shopping center", e disposto a pagar o tributo ("preço") correspondente $^{40}$. Por trás dessa lógica pode estar a idéia dos indivíduos plenamente racionais conseguirem endogeinizar o beneficio esperado de um gasto publico em sua função utilidade; e, portanto, esse benefício estaria mais eficiente quanto mais próximo desses indivíduos fosse dispendido.

Em comum, os mundos de Tiebout e de Musgrave usaram a mesma definição de bens de consumo coletivo tomando-a pela definição de bem público, ou seja, é aquele bem que um indivíduo consome sem reduzir a oportunidade de outro fazê-lo.

\footnotetext{
${ }^{38}$ Entre eles, Musgrave (1959), conforme já observado na sub seção 2.2.

39 Na sequiência, outros autores como Oates (1972), passaram a associar o federalismo fiscal a uma estrutura do setor público com pelo menos dois níveis de tomada de decisão, para então passarem à discussão sobre o grau de centralização dessa tomada de decisão.

${ }^{40}$ O mundo de Tiebout não prevê o indivíduo adotando comportamentos oportunísticos. Ou seja, até mesmo em razão de sua racionalidade econômica plena, quando se admite que o indivíduo seja capaz de perceber suas próprias preferências por serviços públicos de saúde, então, por consequiência, há que se admitir também que esse mesmo indivíduo procure maximizar suas preferências demandando o serviço público sem pagar o devido "preço". Evidentemente, é uma situação que se agrava com acesso universal aos serviços prestados de saúde pública.
} 
No entanto, outros autores como Olson (1971), restringem a definição de bem coletivo como um "sub conjunto" de bens públicos, por meio da imposição de alguma restrição de acesso. É possível se aplicar o conceito de bem de consumo coletivo ${ }^{41}$ definido por Olson à prestação de quaisquer serviços. No entanto, o de saúde pública poderia ser uma exceção, até mesmo em razão do princípio da universalidade de acesso, que independe da jurisdição municipal de origem do indivíduo tomador desse serviço. Inclusive, é possível se observar o consumo de serviço de saúde pública a partir do “transbordamento" de sua oferta de um Município a outro.

Além disso, não há como corresponder com suficiente eficiência a quantidade demandada desse serviço coletivo a indivíduos distintos, com funções utilidades diferentes, e com diferentes disposições a aceitar o tributo correspondente, com o fato de que, o serviço público de saúde tem que prover um acesso universal.

Esse argumento evidencia uma diferença entre os mundos de Musgrave e de Tiebout. Para o primeiro, não existem mecanismos ${ }^{42}$ capazes de induzir os indivíduos a revelar suas reais preferências, de modo que a União pudesse adaptar sua normatização a elas. Enquanto isso, o mundo de Tiebout desenha um indivíduo com ampla mobilidade intersetorial, que demanda entre os diversos serviços públicos ofertados aquele que se ajusta aos seus padrões individuais ${ }^{43}$, e assim, revelando sua preferência.

Há uma evidência interessante no federalismo brasileiro, e que encontra correspondência teórica com o mundo de Tiebout, principalmente, quando se considera

\footnotetext{
${ }^{41}$ Um bem coletivo difere do bem público, segundo Olson (1971), pela existência de alguma restrição de acesso. Definindo melhor, a maioria dos benefícios coletivos só pode ser definida com relação a algum grupo específico de indivíduos. Além do mais, alguns benefícios que são coletivos para alguns grupos de indivíduos podem ser privados para outros, na medida em que estes forem impedidos de desfrutar daquele beneficio. Outro ponto é que uma vez definido o grupo de indivíduos pertinente, está implícita na definição de beneficio coletivo, a inviabilidade de excluir os indivíduos desse grupo alvo do beneficio.

42 Por outro lado, Musgrave (1959) se manifesta da seguinte forma, quanto à necessidade de mecanismos a nível municipal, com objetivo no equilíbrio orçamentário: "Defrontamo-nos assim com a necessidade de examinar os processos através dos quais os indivíduos podem ser induzidos a revelar suas preferências. Isto requer um mecanismo de votação, juntamente com uma aplicação compulsória do plano orçamentário assim determinado. A própria necessidade de aplicação compulsória de uma formula tributária geral significa que a solução resultante não será ótima" . Diga-se, nas "entre linhas" de sua referência à necessidade de um orçamento compulsório, pode-se inferir o reconhecimento implícito da existência de assimetrias informacionais.

${ }^{43}$ Desde que aceita a hipótese implícita de que, no limite, o número de Municípios seria o mesmo que o de indivíduos.
} 
a capacidade dos indivíduos acessarem o serviço público motivada pela busca da maximização de suas utilidades.

Essa evidência é a demonstração de que os gastos em serviços próximos ao indivíduo, como os de saúde pública, por envolverem os Municípios como provedores desse serviço, justifica-lhes a atribuição constitucional da capacidade de gestão autônoma em relação aos demais entes federativos, inclusive à União.

Por outro lado, ainda no federalismo brasileiro, a responsabilidade fiscal seria também uma variável a ser considerada na discussão sobre gastos públicos, uma vez que se correlaciona com as restrições orçamentárias, e, portanto, com a quantidade e a qualidade do serviço a ser provisionado.

Por outro lado, nada impede que a associação de vontades políticas municipais possa centralizar ações coordenadas a nível regional, ao invés de ser na União. Ou mesmo, justificar-se concentrada na União a tomada de decisão, com o contra-argumento de que em um cenário descentralizado os Municípios estariam mais preocupados com os seus próprios indivíduos do que com os dos demais.

De qualquer modo, justifica-se à União a capacidade constitucional de determinar a política básica de saúde e de definir parâmetros a serem considerados no grau de implantação dessas políticas a nível municipal e/ou regional, incluindo suas regras de acesso.

Portanto, considerando o conceito de mobilidade do mundo de Tiebout, inferimos para a função alocativa que o deslocamento dos indivíduos proporciona ganhos com a escolha descentralizada e individual, entre vários padrões de provisão de serviços públicos de saúde, também descentralizados. No entanto, contra um grau elevado de descentralização, haveria ${ }^{44}$ o argumento de que a competição fiscal intermunicipal poderia afetar negativamente os ganhos alocativos pretendidos.

Porém, embora Tiebout (1959) não tenha previsto qualquer interação intermunicipal, se admitíssemos que os diferentes padrões de oferta de serviços municipais são complementares entre si, então, provavelmente se incentivaria a

\footnotetext{
${ }^{44} \mathrm{Na}$ verdade, estas correlações podem justificar a escolha de uma estrutura tributária mais adequada, pois definem não só as escolhas do grau da centralização do federalismo fiscal, mas também, do grau da atividade regulamentadora da política fiscal atribuída à União.
} 
cooperação intermunicipal. E assim sendo, poderíamos definir o grau de centralização da tomada de decisão de ofertar esse serviço como sendo regional por meio da coalizão, em razão do grau de mobilização de todos os indivíduos.

Colocando de outra forma, o nível ótimo de centralização do controle de uma política pública pode surgir de uma solução das questões municipais dessa mesma política por meio de uma análise marginalista de custo e benefício.

No entanto, qualquer argumento pró-cooperação esbarra no transbordamento dos efeitos da política fiscal de um determinado Município sobre seu(s) vizinho(s), principalmente quando se consideram, ao lado da guerra fiscal, outros fatores, tais como, o "relaxamento" da auto-regulamentação de arrecadação fiscal.

Inclusive, em razão das ineficiências geradas pela competição interjurisdicional, alguns autores justificam a centralização da regulamentação das políticas públicas, incluindo a de saúde pública, na União. Diga-se de passagem, Oates (1998) chega a justificar a intervenção de um ente coordenador e regulamentador, afirmando que este viria para "salvar os Estados e Municípios deles mesmos" .

Por outro lado, há visões contrárias a essa conclusão. Elas se baseiam no argumento de que as decisões ao nível municipal, por estarem próximas aos indivíduos, maximizariam o bem estar destes. E, seriam mais eficientes, mesmo se houvesse o acirramento da competição tributária entre Municípios vizinhos.

Esse é um ponto de vista que desconsidera o bem estar de futuras gerações, pois os graus de descentralização assim obtidos estariam respaldados em modelos como o de Tiebout (1956), que desconsideram que as decisões tomadas unicamente a nível municipal envolvem uma estrutura social continuamente mutável.

Além disso, como os Municípios são mais susceptíveis a constrangimentos políticos que os demais entes federativos, e, conseqüentemente, "relaxam" sua administração tributária, e acabam "envolvendo-se" em competição físcal intermunicipal. Novamente, retomamos os mesmos argumentos que justificam a centralização da regulamentação de uma política pública.

No entanto, ainda temos que considerar o custo político-econômico que a sociedade como um todo incorre proporcionalmente com o grau de centralização de 
uma política pública, principalmente, em meio a restrições orçamentárias frouxas ${ }^{45}$. Ou seja, no caso da concentração da decisão na União identifica-se uma correlação direta entre a expansão do seu setor público como um todo, com a expansão de seu orçamento público. Para essa correlação, a descentralização da política pública nos Municípios e a ampliação da competição intermunicipal poderiam ser um mecanismo minimizador.

Tanto que, em uma região formada por vários Municípios, poderíamos ter um contexto onde, segundo Oates (1998), a "mobilidade interjurisdicional das pessoas em perseguir os ganhos fiscais pode oferecer substitutos parciais ou possivelmente completos às restrições fiscais explícitas sobre o poder de tributar ". Ou seja, considerando-se que a disposição dos Municípios à competição fiscal se mantenha constante, o aumento da mobilidade (que aumenta a descentralização) diminui o poder tributar e, portanto, aumentam-se as restrições orçamentárias à ampliação do tamanho do setor publico ${ }^{46}$.

\section{3. a questão das transferências financeiras intergovernamentais}

Uma critica ao mundo de Tiebout é a de que nele não há quaisquer interações entre Municípios, e destes com os outros entes federativos. Esse isolamento dos

\footnotetext{
45 Aqui entendido quando não há fortes preocupações com as preferências dos indivíduos, e nem com o equilíbrio orçamentário.

46 Para ilustrar a idéia de que o tamanho do setor público varia inversamente com o grau de descentralização, consideremos uma área metropolitana, portanto, com alto grau de mobilidade intermunicipal, e pelo menos um Município proporcionalmente maior em relação aos demais. Nessa área o tamanho dos respectivos setores públicos dos demais Municípios varia diretamente proporcional com a dimensão da mobilidade dos indivíduos em se afastar de seus respectivos Municípios. Portanto, se esses Municípios "administrarem" a mobilidade de seus respectivos indivíduos, de tal modo que, ampliando-a, induzam à centralização regional dos serviços no Município de maior porte; então, teríamos um efeito indireto observável com a ampliação relativa da estrutura dos serviços públicos prestados em seus respectivos Municípios, por meio da redução do número absoluto de seus indivíduos residentes, que ali se manteriam demandando os serviços de saúde pública. Tem-se, assim, um paradoxo: o aumento de centralização regional dos serviços públicos no Município de maior porte "amplia" em termos relativos o tamanho do respectivo setor público nos demais, abrindo-lhes espaço para uma redução em termos absolutos. Ou seja, a descentralização regional pode contribuir mais para a redução do tamanho do setor público em termos absolutos na região, do que a ampliação da concentração desse serviço em um único Município, considerando que este relute em ampliar investimentos para suprir a demanda reprimida de outros Municípios.
} 
Municípios, como que em "redomas", em nada se correlaciona com a estrutura tradicional de um federalismo fiscal, na qual, é intrínseca a existência de interações de um ente federativo com os demais. Essas interações, em sua maioria, envolvem transferências de recursos diversos, destacando-se aquelas relativas às transferências verticais advindas da União aos Municípios.

De imediato, a teoria do federalismo fiscal identifica nas transferências financeiras uma eficiente ferramenta instituída pelo pacto federativo para o exercício das funções distributivas e alocativas, portanto, importante nas interações entre os entes federativos, em especial, a União e os Municípios.

Por outro lado, observamos que as transferências financeiras voltadas a financiar gastos públicos municipais "cartelizam” os Municípios, podendo reduzir os benefícios da competição horizontal, na medida que trazem uma indesejável tendência à uniformização das alíquotas tributárias na região.

Afinal, ao se ampliar a dependência de um Município às transferências financeiras recebidas para o custeio de seus gastos públicos, também o induz a subestimar a sua capacidade de financiar seus gastos com receita própria. Uma conseqüência direta disso é o Município também subestimar os riscos de uma externalidade fiscal sobre sua própria base tributária, conduzindo "frouxamente" a sua própria política de alíquotas tributárias, o que de certa forma, poderia afetar a condução de suas políticas públicas, entre elas, a da saúde.

Portanto, com o foco na cooperação intermunicipal, devemos abordar como os Municípios se comportam diante da expectativa de serem receptores líquidos de transferências financeiras de outras esferas de governo, em especial, a União, e, em geral, atreladas a alguma forma normativa.

Inicialmente, e a partir da teoria do consumidor, define-se o conceito de restrição orçamentária como a provável receita que um ente federativo dispõe para cobrir determinados gastos. Porém, no federalismo fiscal brasileiro a restrição orçamentária poderá variar em termos de "rigidez" na medida em que cada ente federativo se disponha a incorporar em sua função utilidade as normas de responsabilidade fiscal. Ou seja, quanto mais "frouxa" a restrição, maior a 
probabilidade desse ente federativo não se propor a manter o orçamento fiscal equilibrado $^{47}$.

De qualquer forma, a correlação que fazemos entre o orçamento público e as transferencias financeiras é a seguinte: quanto mais "frouxa" for a restrição orçamentária de um Município, maior seria tendência deste em incorrer em gastos sem se preocupar em gerar receita própria, principalmente, se as transferências recebidas não se vinculam a qualquer forma de equilíbrio orçamentário, ou de serviço público a ser prestado.

Feita a correlação, passamos especificamente às formas de transferências ${ }^{48}$ financeiras da União aos Municípios que se vinculam à provisão de algum serviço público. Essas transferências são indicadas tanto ao desenvolvimento de programas que envolvam o gasto municipal em específicas políticas públicas, tais como a da saúde pública, quanto às questões ${ }^{49}$ de externalidade; evidenciando sua potencialidade como instrumento de indução.

Quanto ao primeiro aspecto, o da aplicação de programas de políticas públicas, e dependendo se as transferências financeiras são vinculadas ou não e, do grau cooperação entre os níveis de governo, infere-se a possibilidade dessas transferências financeiras serem utilizadas como instrumentos políticos voltados a influir na autonomia político-administrativa dos Municípios definida pelo pacto federativo. Ou seja, além de influir na disposição à arrecadação tributária própria, também influencia na decisão de onde gastar suas receitas obtidas. A principal consequiência é a desvinculação, mesmo que parcial, da receita própria em relação aos gastos totais dos

\footnotetext{
${ }^{47}$ Pela ótica contratualista, a tendência de um ente federativo a observar a restrição orçamentária se revelaria pela de não cumprir com os contratos quanto maior fosse a expectativa de renegociá-los.

${ }^{48}$ Segundo o modelo de Shah (1993), as transferências quanto a forma podem ser vinculadas ou não vinculadas. São vinculadas quando houver no contrato constitucional alguma forma expressa de vínculo, seja quanto à definição do percentual do volume total de um tributo arrecadado a ser destinado a outros entes federativos, seja quanto à sua partição e o destino de sua distribuição. Em complemento, podem ainda ser condicionadas ou incondicionadas, em função de sua aplicação ser ou não dirigida à oferta de determinado bem ou serviço público.

${ }^{49}$ Embora, as primeiras normatizações da União referentes ao setor de saúde pública não revelassem qualquer intenção em lhe dar com questões sobre externalidades.
} 
Municípios, principalmente aqueles voltados à política pública “induzida” pelas transferências.

Quanto ao aspecto das externalidades, as transferências financeiras podem induzir os Municípios receptores líquidos a internalizar os benefícios que possam prover aos indivíduos de outros Municípios. Dessa forma, até uma transferência

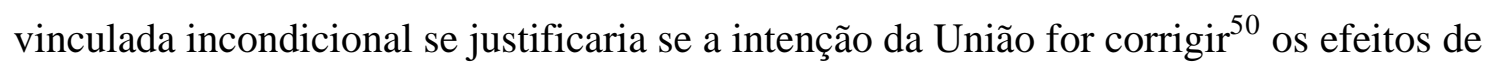
transbordamentos intermunicipais. Por outro lado, como as transferências são incondicionais, potencializa-se a competição vertical entre os Municípios receptores pela melhor adaptação relativa às regras regulamentadoras fixadas pela União de uma política pública, podendo ocorrer a "super dissipação" dos recursos transferidos, reduzindo sua eficiência ${ }^{51}$ distributiva, e, portanto, passando às transferências não vinculadas uma maior participação na aplicação de políticas redistributivas.

Portanto, os ajustes redistributivos pretendidos pela União podem ser realizados por meio de transferências financeiras não vinculadas e incondicionais, sem qualquer compromisso quer seja com um percentual sobre a arrecadação da União, quer seja com o gasto em uma dada política pública por qualquer dos Municípios receptores, principalmente, se a União deseje corrigir desequilíbrios ${ }^{52}$ entre eles.

No entanto, convém observar que a transferência não vinculada e incondicional pode muito bem ser uma ficção, pois, quando a União fornece de forma

\footnotetext{
${ }^{50}$ Para ilustrar, retornemos à região metropolitana. Considerando uma transferência vinculada e ilimitada dirigida ao Município de maior porte tal que, ao prestar serviço público de saúde consiga avaliar tanto o custo de ofertá-lo, quanto o diferencial entre custo e o beneficio de ofertá-lo. Ora, se esse Município receptor é capaz dessa análise, então estaria em condições de incorporar, em seus cálculos, a ampliação dos benefícios aos indivíduos de outras jurisdições que fazem uso e proveito do serviço por ele ofertado, justificando, a partir desse suposto transbordamento intermunicipal, um ajuste alocativo por meio de transferências financeiras, tal qual fosse um subsídio a ele direcionado, voltado a este serviço público até então sub produzido ao nível da região.

51 Além disso, um programa de transferência pode não corresponder ao que a teoria econômica tradicional propõe, pois é muito difícil acreditar em qualquer grau de precisão na definição prévia da cota parte do volume tributário transferido, que uma vez vinculado a algum programa, corresponda diretamente a transbordamentos na direção de certo Município oriundos de outros.

52 Além disso, quando a União realiza transferências incondicionadas entrega aos Municípios receptores condições financeiras de acomodar politicamente grupos de interesses identificados entre os indivíduos contrários a determinado investimento público, e de efetuar gastos públicos não previstos. Essa necessidade poderia ser agravada pela resistência política dos Municípios de ampliar sua receita própria.
} 
não vinculada, no mínimo pretende induzir o Município receptor a algum comportamento específico.

Também é interessante notar que, independente da utilização das transferências vinculadas ou não na indução à cooperação intermunicipal, a necessidade de gasto em uma política pública regional de saúde, onde Municípios vizinhos decidam inclusive pelo gasto cooperativo para a prestação desses serviços, ainda assim, poderá acirrar-se a competição tributária entre esses Municípios.

Por outro lado, o financiamento desse gasto público via transferência reduziria a necessidade de se ampliar os tributos, reduzindo a credibilidade dos grupos de pressão de indivíduos "descontentes" que ameaçam incrementar o grau de mobilidade intermunicipal, e, por conseqüência, também reduzindo as condições para a competição tributária; e dessa forma, ampliando as condições para um comportamento mais cooperativo ${ }^{53}$.

\section{6. algumas limitações da teoria tradicional em explicar a cooperação intermunicipal}

Ao longo deste capítulo nossa abordagem procurou pelas interações entre diversos entes federativos a partir de um enfoque sobre externalidades horizontais e verticais, na medida em que estas envolviam diversos entes federativos. Essa abordagem evidencia os Municípios como doadores ou receptores líquidos de serviços públicos, em especial, os de saúde; em razão de implicações das externalidades nas políticas alocativa e redistributiva dos Municípios.

Um ponto que não foi mencionado ao longo deste capítulo, embora implícito, é a suposição de que a estrutura fiscal era dada. Tanto que, em assim sendo, nos concentramos nas implicações da estrutura suposta existente, e não nas razões dela existir.

\footnotetext{
53 Além disso, a União, por meio das transferências, poderia amplificar o papel de indutor à cooperação intermunicipal, se vinculasse essas transferências na direção da cooperação em sua regulamentação a política pública.
} 
Tratamos das externalidades em meio ao federalismo fiscal brasileiro buscando entender a relação existente entre a União e os Municípios. Tanto é verdade, que as normatizações de políticas públicas da União, e, portanto, os critérios para as transferências financeiras da União aos Municípios impactam nos orçamento públicos municipais.

Além disso, a regulamentação das políticas públicas em um sistema federativo tem consequiências redistributivas que também se realizam por meio da interação dos entes federativos. Até por que, ainda que a União atue como um planejador central, ela deveria levar em consideração que os Estados e Municípios poderão direcionar os recursos distribuídos segundo a visão de uma autonomia administrativa, na medida em que o federalismo fiscal brasileiro não é um sistema unitário.

Portanto, uma primeira conclusão é que as interações do sistema federativo podem conduzir a um resultado melhor, que não necessariamente o ótimo projetado, ainda que a União se comporte como um planejador centralizado. Afinal, nada impede que o equilíbrio a nível nacional seja múltiplo, podendo ocorrer por regiões em função das possíveis posturas alocativas dos recursos, adotadas por alguns Municípios a partir do que se supõem serem as preferências de seus residentes.

Um outro tópico que abordamos neste capitulo é a competição tributaria, ou a chamada "guerra fiscal", a qual se mostrou uma variável correlacionada negativamente com a cooperação intermunicipal. E, a primeira idéia que surgiu é a de que a competição tributária é nociva, na medida em que conduz à prática de alíquotas tributárias ineficientemente baixas, e, portanto, ineficientes ofertas de serviços públicos.

Porém, há circunstâncias em que a competição tributária tem aspectos benéficos, se considerarmos que as mobilidades de indivíduos e de fatores podem induzir os Municípios, dentro da racionalidade econômica, a assumirem posturas pela otimização e redução de desperdícios de seus recursos, e, com isso, reagirem pró ativamente pela cooperação intermunicipal. É só nos lembrarmos do mundo de Tiebout, em que os indivíduos revelam suas preferências ao escolher o Município pelo padrão ofertado de serviço público como se estivessem em um "shopping center". Ou seja, se o serviço público fosse provido tal qual o seria pelo setor privado, então a 
competição na oferta do melhor padrão conduziria à eficiência e realçaria os incentivos à mobilidade de indivíduos e de fatores ${ }^{54}$.

Assim sendo, a competição intermunicipal teria bons e maus aspectos, variando com os atributos que se espera dos serviços públicos de saúde providos aos indivíduos pelos Municípios.

Com isso, se abre espaço à intervenção da União como regulador e indutor dessa oferta. Afinal, Municípios em "guerra fiscal", muito provavelmente, terão que ser "induzidos" à cooperação. De qualquer forma, se os indivíduos tivessem ampla mobilidade, a exemplo do que vimos no mundo de Tiebout, então, os Municípios a partir da mobilidade dos indivíduos, teriam também um mecanismo ${ }^{55}$ revelador dos padrões de saúde publica demandados pelos seus residentes.

No entanto, o mundo de Tiebout é composto por tantos Municípios quantos sejam os padrões desejáveis de prestação de serviços, o que representa uma restrição à sua utilização na questão central deste trabalho: a cooperação intermunicipal. Ou seja, a sua estrutura teórica pressupõem o não comprometimento interjurisdicional, não permitindo que haja qualquer espaço teórico para a racionalização regional dos recursos ${ }^{56}$.

De qualquer forma, pudemos identificar no mundo de Tiebout, que a competição $^{57}$ realça o bem estar quando há a livre mobilidade dos indivíduos e dos

\footnotetext{
${ }^{54}$ No entanto, qual seria o valor econômico desse serviço para o setor privado se o consumo de um indivíduo não pode comprometer o de qualquer outro, e, se prevalece o princípio do acesso universal? Além disso, se assim fosse, também deveríamos reconhecer que estes incentivos operam em um ambiente com falhas de mercado, e, portanto, o equilíbrio eficiente seria novamente pouco provável.

${ }^{55}$ Com esse mecanismo, os Municípios também poderiam ajustar suas políticas de alíquotas tributárias aos padrões de gastos, que também seriam influenciados pelas externalidades e pelas posturas regulamentadoras da União. Portanto, conhecidas as preferências dos indivíduos residentes, caberia aos Municípios otimizarem os recursos disponíveis.

56 Além disso, no mundo de Tiebout, o efeito das externalidades provocado pela mobilidade de indivíduos e de fatores é amplamente compensado pela hipótese implícita nele: o equilíbrio orçamentário entre gastos e receitas; uma vez que, o desenvolvimento deste modelo pretendeu apresentar apenas um mecanismo de revelação das preferências dos indivíduos na região.
}

57 Ainda com relação à competição fiscal, encontramos Oates (1972) argumentando que este comportamento é ineficiente, pois, se todos os governos agirem assim, nenhum deles obterá uma vantagem competitiva, e, portanto, todos estariam piores. Além disso, no mundo de Tiebout, as externalidades que resultariam da ampla mobilidade de indivíduos e fatores não tem qualquer efeito no 
fatores, e há a capacidade dos Municípios de agirem independentes em várias áreas de política pública. No entanto, a literatura que aborda a competição tributária se preocupa com os efeitos adversos dessa independência. Tanto que, se os Municípios exercerem atividades atribuíveis a mercados privados, infere-se a geração da competição tributária a partir dos problemas de eficiência na provisão desses serviços.

Haveria, então, pelo menos dois tipos de competição tributária, cuja classificação independe dos efeitos da competição serem positivos ou negativos. Temos a competição tributária que se motiva em ampliar receitas, cuja ferramenta principal são as políticas de alíquotas tributárias. E, também temos a que se dá vinculada a um fim específico, cuja ação, em geral, se dá com a elevação de gastos em infraestrutura, subsídios ou incentivos.

No caso específico da competição por meio das alíquotas tributarias, intuímos que deva ter uma baixa correlação enquanto variável explicativa da cooperação intermunicipal. Os dados da tabela I demonstram que a participação de receitas próprias na prestação de serviços públicos de saúde e de saneamento é pequena, perante a participação transferências financeiras da União, o que demonstra sua forte propensão a "indutora" da cooperação aqui objeto de estudo.

A primeira vista, os valores constantes na Tabela I dão a entender que, no ano 2000, a totalidade das transferências financeiras da União aos Municípios é menos de 1/3 dos gastos municipais na rubrica "saúde e saneamento", o que ilustraria a importância da receitas próprias no financiamento dos serviços públicos de saúde. No entanto, apesar das transferências financeiras da União serem apenas 1/3 dos gastos, a arrecadação própria dos Municípios é 17,2\% da receita orçamentária e, portanto, tem uma pequena participação no volume de gastos públicos.

Isso implica que, no federalismo fiscal brasileiro, os gastos municipais em saúde e saneamento estão sendo feitos, principalmente, a partir das transferências financeiras, em especial, as vinculadas a normatizações da União. Portanto, se as despesas com saúde tendem a serem feitas com recursos oriundos de transferências verticais a partir da União, presume-se que o esforço arrecadatório dos Municípios, e,

padrão de gastos dos Municípios; é como se os gastos se ajustassem automaticamente aos efeitos da externalidade, dos quais apenas se evidenciaria, como efeito, o aspecto de eficiência alocativa. 
portanto, a concorrência por meio de uma política de alíquotas tributárias, pouco influem em suas tomadas de decisões em política publica de saúde.

Tabela I - Participação dos Municípios nos gastos em saúde pública

\begin{tabular}{|c|c|c|c|c|}
\hline \multirow[b]{2}{*}{ itens } & \multicolumn{2}{|c|}{ todos os municípios } & \multicolumn{2}{|c|}{ municípios que recebem SUS } \\
\hline & totais & $\begin{array}{c}\text { participação em } \\
\text { relação à receita } \\
\text { orçamentária }\end{array}$ & totais & $\begin{array}{c}\text { participação em } \\
\text { relação à receita } \\
\text { orçamentária }\end{array}$ \\
\hline Saúde e Saneamento & 16.546 .477 .520 & $20,97 \%$ & 12.768 .466 .427 & $23,07 \%$ \\
\hline Rec Orçamentária & 78.912 .200 .042 & $100,00 \%$ & 55.339 .021 .246 & $100,00 \%$ \\
\hline Rec Correntes & 75.360 .336 .338 & $95,50 \%$ & 52.719 .233 .006 & $95,27 \%$ \\
\hline Rec Tributária & 14.785 .439 .691 & $18,74 \%$ & 9.518 .133 .167 & $17,20 \%$ \\
\hline Rec Transf Correntes & 51.190 .114 .717 & $64,87 \%$ & 36.834 .886 .882 & $66,56 \%$ \\
\hline Transf da União & 23.859 .841 .347 & $30,24 \%$ & 17.871 .568 .230 & $32,29 \%$ \\
\hline SUS União & 4.910 .719 .397 & $6,22 \%$ & 4.910 .719 .397 & $8,87 \%$ \\
\hline Transf do Estado & 26.299 .474 .495 & $33,33 \%$ & 18.303 .575 .141 & $33,08 \%$ \\
\hline SUS Estado & 216.341 .987 & $0,27 \%$ & 82.290 .480 & $0,15 \%$ \\
\hline
\end{tabular}

Municípios-ano 2000. (site da Secretaria do Tesouro Nacional)

Por conseqüência, inferimos que a receita própria tenha, enquanto variável explicativa, uma baixa correlação com as motivações dos Municípios à cooperação; inclusive, ratifica esta conclusão, o fato da teoria tradicional aplicada à área tributária otimizar seus modelos, em geral, considerando transferências financeiras intersetoriais, ao invés de receitas próprias.

Uma possível razão para a adoção desse tipo de solução pode estar no fato de a União utilizar as transferências financeiras como instrumentos fiscais para a aplicação de sua regulamentação junto aos demais entes federativos. Além disso, ressalte-se que a teoria tradicional justifica não só a regulamentação, mas também a centralização da tomada de decisão na União, com as economias de escala e a internalização dos transbordamentos entre jurisdições municipais.

Portanto, o mundo de Musgrave no qual se insere a União tomando decisões centralizadas, também se mostra inadequado para explicar como ocorrem as tomadas de decisões a nível municipal, principalmente, aquelas voltadas à adoção da cooperação 
intermunicipal que, necessariamente, se caracterizaria pela decisão coletiva. Afinal, a teoria tradicional se baseia na escolha individual, enquanto a coletiva é ajustada em barganhas travadas em arenas políticas e econômicas, e, muitas vezes, submetida às regras democráticas de uma decisão pelo voto.

Além disso, a teoria tradicional desconhece que os indivíduos que tomam a decisão política, ainda que centralizada na União, têm diferentes funções utilidade; e, portanto, têm diferentes propensões a afetar o equilíbrio de poderes entre os vários grupos de interesses regionais, e, por conseqüência, a induzir a formação de uma cooperação intermunicipal. E, também desconhece as preferências da maioria dos indivíduos, o que condena a União a tomar decisões ineficientes de provisão de recursos em relação às que seriam tomadas descentralizadamente.

E, embora seja aceito tanto no mundo de Musgrave quanto no de Tiebout que a função alocativa tenha a sua tomada de decisão descentralizada, ainda assim, a teoria tradicional de finanças públicas procura explicar a provisão centralizada justificando-se pela maximização do bem estar social.

Enquanto isso, pelo lado redistributivo, embora a teoria econômica tradicional também defenda a centralização das políticas redistributivas, nada impede que alguns Municípios se oponham a transferências líquidas aos indivíduos de jurisdições vizinhas. Por outro lado, se presumirmos que uma decisão centralizada pode ser eficiente, como preconiza a teoria tradicional, não haveria como se avaliar o quão centralizado deveria ser a tomada de decisão para garantir a maximização de sua eficiência, dada a heterogeneidade das preferências observadas em qualquer processo de decisão. Além disso, também não há como garantir a eficiência de uma tomada de decisão centralizada na medida em que, ferir interesses de alguns, ou favorecer outros, dificulte qualquer conclusão normativa.

Isso simplesmente ocorre porque o consenso absoluto entre os vários níveis federativos costuma ser uma falácia. Afinal, o princípio da autonomia administrativa conduz a uma decisão descentralizada, com todos os problemas de assimetria informacional e de comportamentos oportunísticos advindos dela. E, é por isso que não se pode esperar consenso entre os Municípios, sendo necessária alguma flexibilização 
na tomada dessa decisão coletiva sem a imposição de uma regra por maioria absoluta, e, sem que isso justifique se remeter a tomada de decisão à União.

Por outro lado, também não se pode negar à União a atribuição de regulamentar as políticas públicas, pois, afinal, o processo de tomada de decisão descentralizada também se sujeita a falhas de coordenação. A identificação dessas falhas impõe a necessidade de mecanismos institucionais aptos a coagir os Municípios envolvidos a um comportamento adequado.

Finalmente, algumas considerações sobre as variáveis vinculadas ao orçamento público, e tratadas pela teoria tradicional de finanças públicas. Neste caso, se não houver um vínculo comprometendo uma parte da receita tributária ${ }^{58}$ dos Municípios com o volume de gastos necessários à política pública de saúde, pode-se argumentar que o processo político de tomada de decisão pode conduzir a uma subprovisão desse serviço publico, na medida em que os critérios de gastos públicos sejam "frouxos". Em outras palavras, haveria uma tendência a dificultar o repasse de recursos voltados à cooperação intermunicipal, mesmo com aumento da arrecadação tributária; pois, quando se provisiona antecipadamente uma parte da receita tributaria, também se vincula a origem do tributo com os receptores dos benefícios financiados por essa parte $^{59}$.

E dessa forma, quando sob a ótica da escolha pública tratarmos dos benefícios esperados pelos indivíduos a partir de serviços prestados por um conjunto de Municípios, deveremos também buscar a minimização dos custos políticos desses mesmos Municípios na gestão de seus respectivos sistemas ${ }^{60}$ de alíquotas tributárias. Ainda que essa gestão objetive a ampliação das receitas tributárias, há que se

\footnotetext{
${ }^{58}$ Independe das receitas terem origem em bases tributárias próprias ou de transferências financeiras.

${ }^{59}$ Buchanan (1967) observa, que poderá ocorrer “(...) um incentivo aos beneficiários em potencial pela tentativa de financiarem seus benefícios com uma receita vinculada e aplicada de um outro grupo"

60 Holcombe (1998) adverte que o “(...) sistema tributário não provê um bom mecanismo de redistribuição, por duas razões: primeiro, o uso explícito do tributo como um mecanismo redistributivo convida à escalada dos custos políticos; e, segundo, o processo de tomada de decisão democrática não é muito apropriado para realçar o bem estar social através de uma redistribuição de qualquer maneira, pois ele favorece aqueles com o poder político mais do que aqueles que estão em necessidade"
} 
demonstrar que a divisão dessas receitas entre eles se reverta em gastos que correspondam aos benefícios esperados, no mínimo, pela maioria dos indivíduos.

Ou seja, também há que se considerar o ambiente político e institucional onde se processam tomadas de decisões, para a qual a teoria tradicional se mostra limitada.

Assim sendo, a partir do próximo capítulo, usaremos dos recursos da teoria da escolha pública para explicar a cooperação intermunicipal, incorporando ao estudo variáveis que também expliquem as motivações dos Municípios em empreender gastos fiscais. Até porque, quer seja pelo enfoque normativo, quer seja pelo contratualista, muito provavelmente, os indivíduos fariam uso racional de sua mobilidade para obter os benefícios desejados, ainda que vinculados aos gastos públicos de outros Municípios.

Nesse processo incorporaremos as tomadas de decisões coletivas dos residentes, e de como estas interagem com as dos respectivos Municípios. Afinal, dada a mobilidade dos indivíduos e fatores, é inadmissível se entender a tomada de decisão dos Municípios sem que a correlacionemos com as preferências de seus indivíduos residentes.

De qualquer forma, demonstra-se a inadequação da teoria tradicional de finanças públicas para explicar a cooperação intermunicipal. Por um lado, o mundo de Musgrave busca resolver as questões atinentes à externalidade com a centralização da tomada de decisão na União. Enquanto isso, o mundo de Tiebout simplesmente desconsidera a existência de externalidades.

Ressalte-se que a mudança de um enfoque de exclusivamente normativo pela teoria tradicional, para um enfoque que inclua o aspecto contratualista da teoria de contratos, deve-se à presunção que fazemos de que a formação de uma cooperação intermunicipal enfrentaria problemas de um contrato incompleto ${ }^{61}$. Ao mesmo tempo em que não devemos abandonar totalmente o enfoque normativo, pois, ainda que a função alocativa fosse plenamente descentralizada, restariam as acomodações oriundas pela interação da União com os Municípios voltada aos efeitos redistributivos na

\footnotetext{
${ }^{61}$ Afinal, partimos da presunção de que seja impossível um contrato assegurar totalmente o compromisso entre os Municípios, e a sua credibilidade. Afinal, se os compromissos fossem sempre criveis, por definição, dispensada estaria a existência de contratos.
} 
região, e, para a qual, se faz necessária a normatização das ações de política pública de saúde.

Para ilustrar este ponto de vista, é interessante trazermos o seguinte argumento de Holcombe (1998), segundo o qual, a teoria de escolha pública sugere que a redistribuição produzida pelo sistema político é “(...) um constante ajuste normativo pós-constitucional combase em regras do contrato constitucional(...)” . Até por que, se assim não o fosse, qualquer tomada de decisão democráticapós-contrato, dificilmente conseguiria um padrão estável de redistribuição.

Também temos a expectativa de que a teoria da escolha pública possa explicar como a redistribuição normatizada pela União, pode induzir os Municípios à cooperação regional, o que não encontramos na teoria tradicional. Provavelmente a decisão dos Municípios pela cooperação deverá se pautar em uma divisão aproximadamente proporcional dos benefícios esperados, aceitando que as decisões sobre política pública de saúde não se dêem tão descentralizadas, como a que seria obtida individualmente pelos Municípios, ao mesmo tempo em que, também não sejam excessivamente centralizadas na União.

Evidentemente, a racionalidade econômica persistiria na decisão dos Municípios. Ou seja, a motivação esperada para esse acordo de cooperação intermunicipal, ainda que produza um resultado ineficiente, é a que deixe todos os Municípios envolvidos melhores do que estariam se a redistribuição na região não acontecesse por meio dela. 


\section{CAPÍTULO II}

\section{UM ENFOQUE ALTERNATIVO À COOPERAÇÃO INTERMUNICIPAL}

\section{1. apresentação}

Num ambiente intermunicipal competitivo, imerso em uma "guerra fiscal", é possível se identificarem entre personagens como a União e os Municípios, algumas assimetrias de informação dos efeitos das externalidades sobre os gastos públicos, além das assimetrias entre os Municípios, observadas na disposição destes em coletar tributos da base própria, e de como isso também impacta nos gastos.

Embora a estrutura tributária vigente tenha conferido aos Municípios bases tributárias próprias, estes acabam assumindo a condição de receptores líquidos de transferências financeiras vinculadas à regulamentação ${ }^{62}$ da União de políticas públicas, tais como a da saúde pública, em prol de uma visão normativa da teoria tradicional.

No capítulo anterior, vimos, pela ótica normativa, que a competição pelas bases tributárias é instrumentalizada com a política de alíquota tributária. E, também, vimos que ela pode ter um efeito inibidor da cooperação, na medida em que o volume necessário de gasto das ações cooperadas se vincule à obtenção ou ampliação de recursos próprios.

E, embora o enfoque normativo da teoria tradicional não consiga explicar como ocorre a cooperação intermunicipal, a partir de algumas de suas implicações

\footnotetext{
${ }^{62}$ Um critério freqüentemente aventado de rateio das transferências financeiras da União aos Municípios é o que se correlaciona diretamente com o "esforço fiscal" de cada Município. Esse critério é interessante como incentivo pelo empenho dos Municípios em financiar seus serviços públicos com suas próprias bases tributárias, ofertados autonomamente ou em cooperação intermunicipal. No entanto, esse critério pode representar um incentivo negativo aos Municípios que mantêm suas alíquotas tributárias ineficientemente baixas. Esse critério também pode deprimir ainda mais o volume de prestação autônoma de serviços de Municípios com reduzida ou nenhuma capacidade de provisão, e, portanto, com ampla demanda reprimida por serviços públicos. Além disso, é um critério que pode suscitar comportamentos assimétricos entre os Municípios em cooperação, na medida em que alguns deles possam arrecadar a uma baixa alíquota tributária em relação às demais, enquanto os outros os "penalizariam", ampliando relativamente suas parcelas das transferências financeiras da União, inviabilizando a participação dos primeiros na cooperação.
} 
teóricas iremos estruturar variáveis de cunhomotivacional, que se pretendem explicativas da cooperação intermunicipal. Entre essas implicações, destacam-se: a alocação adequada dos recursos, as políticas de alíquotas tributárias, o papel das transferências intergovernamentais e a normatização da União.

A partir da prática de uma política de alíquotas tributárias, ferramenta da competição tributária, podemos presumir a existência de um ambiente político no qual se consubstanciam custos políticos pela adoção de uma dada política de alíquotas. Ou seja, os gastos públicos seriam influenciados pela existência de custos políticos em obter recursos para tanto. Obviamente, a presunção da existência de custos políticos, também pressupõe a existência de assimetrias entre os Municípios.

Se os custos políticos podem advir das assimetrias entre os personagens, então, os Municípios poderiam agir no sentido de minimizá-los. A ação nesse sentido poderia ser "ex-ante" a uma tomada de decisão pró-cooperação intermunicipal, quando então se deveriam prever no acordo intermunicipal algumas condições que os obrigasse ao pagamento das cotas parte, vinculando-as ao acesso e à exclusão aos serviços prestados em comum pelos Municípios.

Quanto à variável custo político, esta também poderia nos ajudar a entender ${ }^{63}$ melhor a relação existente entre mobilidade e externalidade, abordada no capitulo anterior. Afinal, o custo político de um Município envolvido na cooperação intermunicipal seria em razão da eficiência dos resultados esperados, expressa em votos perdidos/contrários que revelariam a insatisfação dos indivíduos quando das correlações que estes fariam entre as promessas de campanha e o resultado esperado da prestação de serviços.

Evidentemente o resultado esperado dependeria do cenário previsto. Num cenário em particular, onde cada Município agisse "per si”, a competição pelos votos nas respectivas eleições municipais incitaria os indivíduos a votarem em políticas que invalidassem quaisquer incentivos à migração intermunicipal.

\footnotetext{
${ }^{63}$ Neste caso, se fazem necessárias duas suposições: a primeira é a de que se mantém a mobilidade de indivíduos e de fatores de produção de serviços públicos entre as jurisdições municipais, e, a segunda é a de que a cooperação intermunicipal, induzida ou espontânea, é capaz de contrabalançar as ineficiências das políticas propostas ao setor de saúde pública pelos Municípios individualmente.
} 
Porém, numa região onde os Municípios decidam pela cooperação, necessariamente deveria haver incentivos à mobilidade cujas intensidades variariam inversamente com os ganhos surgidos a partir da cooperação intermunicipal.

Quanto ao acordo de cooperação intermunicipal, este poderia ser estruturado na forma de um ou vários contratos entre eles, em razão do grau de comprometimento e do esforço de coordenação empreendido para que alguma forma de organização dessa cooperação se consubstancie.

Observe-se que a existência de um ou mais contratos organizando alguma forma de cooperação regional de serviços públicos de saúde pode não ser o suficiente para se evitarem as externalidades e os comportamentos oportunísticos entre os Municípios envolvidos.

Afinal, os indivíduos têm diferentes funções utilidade, e, portanto, diferentes propensões a assumir suas escolhas entre pró ou contra a cooperação intermunicipal. Além disso, não podemos nos esquecer de que a função utilidade dos indivíduos também é explicada por variáveis vinculadas a outras políticas públicas, e, portanto, numa escolha polarizada entre essas duas ideologias, há que se considerarem, também, os efeitos destas variáveis na decisão a que foram chamados.

Um ponto interessante a se lembrar neste momento é que a teoria tradicional de finanças públicas surge da teoria do consumidor e, portanto, apoia-se na escolha individual. Por isso, nela sempre temos um único indivíduo procurando racionalizar custos e benefícios. E, uma vez que a teoria tradicional pouco, ou nada, considera sobre a vontade coletiva na escolha de bens e serviços públicos, surgiu, como conseqüência, a teoria da escolha pública, também desenvolvida por economistas de origem neoclássica, mas com enfoque em economia política.

Assim sendo, a teoria da escolha pública, ou coletiva, acaba mantendo a noção neoclássica de indivíduo. No entanto, trata das várias escolhas individuais em meio a um processo político de tomada de decisão coletiva. Essa decisão coletiva é, então, regulamentada por uma regra democrática, em geral, de maioria simples, de modo que as várias preferências individuais, então reveladas, sejam consideradas em agregado, como a expressão da escolha coletiva. E, a influência neoclássica nesta 
teoria acaba surgindo com essa escolha representando uma única maioria e, portanto, passível de ser "individualizada" em relação a outras possíveis escolhas coletivas.

\section{2. desenhando o cenário}

No transcorrer do detalhamento deste cenário, manteremos a mesma dualidade $^{64}$ do capítulo anterior. Assumiremos os mesmos Municípios ${ }^{65}$ e União, só que agora denominados por personagens centrais. Um terceiro personagem central poderiam ser os Estados; no entanto, eles estão à margem neste estudo, pois exercem o papel de certificador da conduta dos Municípios em relação às normas da União.

Por outro lado, reconhecem-se neles as suas contribuições à cooperação no exercício de um papel de "facilitador" de algumas iniciativas pontuais de estruturação da cooperação intermunicipal ${ }^{66}$. Além disso, os Estados são prestadores de serviços públicos de saúde, principalmente ações de referência regional ${ }^{67}$.

O papel dos Municípios se caracteriza pela iniciativa à integração horizontal, induzida ou não. E essa iniciativa envolveria aspectos motivacionais. Quanto à União, embora regulamentadora da política de saúde pública, poderia ser, ou não, uma indutora à regionalização; e, de qualquer forma, cabendo-lhe os aspectos de coordenação da cooperação. Portanto, o ambiente ${ }^{68}$ é político.

\footnotetext{
$\overline{64}$ Isso nos permite uma racionalização em combinações lineares, ao invés, de espaciais.

65 Os Municípios aqui considerados são os que formam uma região na qual se encontram geograficamente próximos, geralmente, polarizados por um de maior porte.

${ }^{66}$ Essa evidência se ratifica com a norma emitida pela União em 2001, no âmbito da saúde pública, pela qual os Estados, juntamente com a União, deveriam assumir o papel de coordenador da regionalização das ações de saúde pública em suas respectivas jurisdições, podendo ser exercido conjuntamente com outros Estados, se as regiões consideradas abrangerem mais de uma jurisdição estadual.

${ }^{67}$ Por exemplo, o Hospital das Clínicas de São Paulo.

${ }^{68}$ Afinal, é nesse ambiente que ocorrem as barganhas que resultam na política de alíquotas tributárias, na definição do equilíbrio de gastos e receitas, e, na revelação da disposição dos personagens às transferências horizontais de recursos para custear ações cooperadas. Todas essas variáveis se interrelacionam com os custos políticos que advêm das assimetrias impostas pelo processo de negociação, que por sua vez nos remete, fechando um círculo de análise, ao ambiente político no qual ela ocorre.
} 
A arena onde ocorre a barganha política pode ser intra ou intermunicipal, dependendo dos atores envolvidos. Cada uma delas pode representar uma fase na tomada de decisão sobre a integração horizontal das ações públicas de saúde. De qualquer forma, para estudar a barganha política, a literatura explora alguns mecanismos político-eleitorais com o fim de revelar ${ }^{69}$ as preferências dos indivíduos.

Quanto ao ambiente político, a idéia a ser adotada nesse processo de revelação é a de uma visão federativa aplicada à criação de uma estrutura de cooperação intermunicipal, e decidida em duas arenas de interação entre os personagens.

Uma primeira arena seria intramunicipal, onde a decisão individual de um Município se correlaciona com a decisão coletiva dos residentes agrupados pela respectiva jurisdição municipal. Essa decisão político-eleitoral se manifestaria a partir do resultado da aplicação de uma regra de maioria.

A segunda arena seria intermunicipal, e ocorreria a partir de uma decisão coletiva entre os vários Municípios, com a qual, da mesma forma que as partes criam um todo em uma visão federativa, elas, ao estruturarem a cooperação, criariam uma forma organizacional supramunicipal voltada à prestação de serviços públicos de saúde ${ }^{70}$.

As tomadas de decisão dos Municípios são realizadas por indivíduos identificados como as elites políticas municipais e os consumidores-eleitores. Quanto às elites políticas municipais, estas são eleitas por residentes na respectiva jurisdição, e investidas por estes do poder de decisão sobre a aplicação dos recursos públicos.

Procuraremos explicar o comportamento das elites políticas municipais em face de seus respectivos compromissos políticos com a cooperação intermunicipal; desde já, cientes de que são limitados pelos custos políticos de sua já fraca disposição em tributar bases próprias, e, portanto, de financiar a cooperação.

\footnotetext{
${ }^{69}$ Observe-se que, em sua finalidade, pouco diferem do mecanismo de revelação desenvolvido por Tiebout (1956), e nem no mecanismo eleitoral abordado por Musgrave (1959 - capítulo $6^{\circ}$ ).

70 É nesta segunda arena, que os Municípios envolvidos provavelmente se preocupariam com a burocracia da organização da cooperação extrapole suas atribuições, prevendo-se, portanto, que elas estabeleçam restrições autocoercitivas visando conter a discricionalidade da tomada de decisão dessa burocracia, além de preveni-la das pressões de grupos de interesses.
} 


\begin{abstract}
Além disso, há outras fontes de custos políticos ${ }^{71}$ que deprimem suas motivações. Entre elas: a distribuição do "bônus político" entre as elites pelos resultados obtidos da cooperação; as diferentes funções utilidade observadas na maioria dos indivíduos residentes; o consenso sobre recursos e poder de decisão a transferir à burocracia que administraria a cooperação intermunicipal e, o envolvimento em competição fiscal.
\end{abstract}

Quanto aos consumidores-eleitores, estes são indivíduos agrupados segundo a jurisdição de sua residência, os Municípios. Eles são proprietários dos fatores de produção, e podem influenciar nas relações intermunicipais com a sua mobilidade e com o seu voto sob uma regra democrática.

Os consumidores-eleitores têm a expectativa de que a respectiva elite política municipal tome suas decisões, de característica individual, o mais colado possível à decisão coletiva deles, enquanto grupo. Ou seja, esperam que cada elite política municipal se comprometa com suas promessas de campanha, mantendo sua tomada de decisão vinculada às funções utilidade da maioria deles.

Como conseqüência, eles necessitam poder monitorar a ação de seus representantes. No entanto, o monitoramento só seria possível à medida em que os consumidores-eleitores acessem informações que reduzam as suas limitações à racionalidade $^{72}$, embora também possam aprender com as decisões anteriores ${ }^{73}$.

\footnotetext{
${ }^{71}$ Emprestamos a definição de custo político de Holcombe (1998). Segundo este autor, o custo político é motivado pela variação do fardo tributário que altera a função utilidade de um indivíduo em residir num Município. No entanto, existem outras variações de custos, que também influem no processo de tomada de decisão. São as que têm origem no acréscimo dos custos administrativos que os Municípios incorrem em coletar os tributos e impor leis tributárias; no acréscimo dos custos de anuência dos indivíduos de que, calcular e pagar o aumento tributário teve origem na ampliação do serviço esperado; e, nos acréscimos dos custos políticos do sistema tributário relacionado com o processo de tomada de decisão, em especial o dos Municípios, quando estes modificam a estrutura tributária vigente. Há também o custo de redistribuição da renda incorrido pelos grupos de pressão que buscam induzir a legislação tributária em seu benefício. Esses grupos pressionariam pela redução ou eliminação de seus tributos, ou para se resguardarem do tributo no futuro. Esses custos podem influir no desenho de um contrato constitutivo de uma coalizão voltada à prestação de serviços.

${ }^{72}$ Williamson (1986) distingue a racionalidade em três níveis. Um primeiro nível é a maximização neoclássica quando os indivíduos são caracterizados como funções de utilidade, as instituições são dadas, e a otimização é onipresente. Um segundo nível é a racionalidade limitada, uma hipótese cognitiva da economia de custos de transação; significando intencionalmente racional, mas com limitações; ou seja, a racionalidade intencional, mas limitada, é assemelhada à racionalidade, diferentemente da interpretação dos autores que consideram a limitação em termos de não ser racional ou irracionalidade. Dizer que a racionalidade é intencional é reconhecer que a competência de fazer algo também é limitada, implicando
} 
Finalmente, o personagem principal, União. Este exerce o papel de normatizador das ações de política de saúde pública. Sua política de transferências verticais afeta a receita dos Municípios e a sua disposição aos gastos com a cooperação intermunicipal. Age por meio da edição de normas, que de inicio respondem ao conceito constitucional de municipalização das ações de saúde pública.

\section{1. da regionalização}

Quando falamos no cenário regional, nos referimos à possibilidade de um grau intermediário de centralização da decisão de uma determinada política pública, entre a centralizada na União e a descentralizada nos Municípios.

Afinal, as dificuldades ${ }^{74}$ das elites políticas ao compromisso político têm dado argumentos àqueles que defendem a centralização da tomada de decisão. Por outro lado, a realidade tem mostrado a União se transformar de um ente planejador centralizado para um ente indutor das decisões descentralizadas nos Municípios, pois, a existência de assimetrias informacionais confere aos Municípios ${ }^{75}$, mais que à União, o conhecimento das funções utilidade dos respectivos consumidores-eleitores.

no estudo de instituições e na teoria dos contratos, onde as partes contratuais buscarão obter as melhores vantagens possíveis em um processo contratual. O terceiro nível seria o processo ou a racionalidade orgânica, trata-se de um enfoque de processos evolucionários dentro e entre firmas ou grupos de indivíduos, seriam organismos que trabalham mais visando uma certa finalidade do que no processo de atingi-la.

${ }^{73} \mathrm{O}$ interessante do aprendizado coletivo é que ele proporciona uma tendência interna à homogeneização e à ampliação da maioria dentro do grupo de consumidores-eleitores, e, por conseqüência, induz um maior compromisso da elite política eleita por esse grupo de consumidores-eleitores.

${ }^{74}$ Destacam-se as seguintes dificuldades: a distribuição de responsabilidades entre as elites envolvidas, as diferentes funções utilidade observadas nos consumidores-eleitores medianos dos grupos jurisdicionais, o consenso sobre recursos e poder de decisão a transferir à burocracia da coalizão, o comportamento das elites envolvidas em competição fiscal, e, as diferentes capacidades em atender as normatizações da União.

75 Ressalte-se que, se as externalidades intermunicipais tivessem pouca intensidade, e os serviços fossem prestados com eficiência pelos Municípios, então uma União “planejadora centralizada” talvez pudesse também ser eficiente. No entanto, não é isso que se observa. Inclusive, é possível se identificarem alguns sistemas municipais com ofertas ineficientes de serviços de saúde pública, nos quais, algumas de 
Por outro lado, para que os Municípios possam se colocar em melhores condições $^{76}$ de proporcionar uma melhor eficiência distributiva, seria necessário que eles pudessem também compensar as distorções causadas pela competição tributária e pelas externalidades, o que lhes seria muito difícil.

É por isso que, embora tenhamos o foco na teoria da escolha coletiva, deveríamos manter em mente a recomendação da teoria tradicional de finanças públicas pela centralização das decisões redistributivas na União, a qual faria uso das transferências verticais e de normatizações vinculadas. Embora, a teoria tradicional não tenha qualquer preocupação com a União induzindo as elites municipais a um comportamento ${ }^{77}$ cooperativo regional.

Portanto, há uma lacuna na teoria para as várias estruturas de cooperação intermunicipal observadas. Além disso, abre-se espaço à ação da União como indutora da estruturação da cooperação. Essa ação, quer seja como normatizadora plena, quer seja assumindo uma parcela do papel de coordenação com algum enfoque contratualista, poderia minimizar o custo político que as elites políticas municipais incorreriam com integração regional de uma dada política pública, na medida em que amplia a difusão da responsabilidade pelos resultados.

suas elites políticas chegam a "encorajar" a mobilidade dos consumidores-eleitores residentes para que demandem serviços em Municípios vizinhos.

${ }^{76}$ Ou seja, capturar informações sobre diferenças de preferências e de renda dos consumidores-eleitores, sobre a mobilidade na região, e, portanto, sobre a quantidade e a qualidade necessárias de serviços.

77 Segundo Williamson (1986), rechaçam-se as hipóteses comportamentais quando se citando Friedman, segundo o qual o realismo dessas hipóteses não é importante na medida em que a fertilidade de uma teoria considera as suas implicações. No entanto, o homem econômico, diferentemente do organizacional, foi concebido com um alto poder maximizador para simplificar o aparente auto-interesse, o que, "per si", pressupõe a inexistência de incertezas e a desnecessidade de contratos, o que não encontra nenhum respaldo na realidade. Quanto ao homem organizacional, objeto da teoria dos contratos, é cognitivamente menos competente na medida em que está sujeito à racionalidade limitada, mas, motivacionalmente mais complexo pelo oportunismo, do que o homem econômico. Há três atributos de natureza comportamental importantes para o estudo da economia: a racionalidade, a motivação e a dignidade (auto estima). A teoria dos custos de transação se apóia nas duas primeiras, na medida em que o problema da organização econômica é agir com racionalidade limitada, e se salvaguardar contra os riscos do oportunismo. Porém, deve-se também observar a dignidade, sem a qual os indivíduos teriam as características de instrumentos econômicos; e, assim sendo, Williamson propõe que a teoria dos custos de transação também analise as transações pelas quais a dignidade possa influenciar a estrutura de governança (exemplo: ONG's). 
É interessante se reforçar que o enfoque da tomada de decisão regionalizada permeia por todo este trabalho, na medida em que a regionalização de uma política pública não prescinde do aumento da centralização de sua tomada de decisão.

Inclusive, com o aumento da centralização da tomada de decisão, de municipal para regional, algumas decisões de cunho redistributivo, envolvendo essa determinada política pública, poderiam ser possíveis. É com essa abordagem que pretendemos dar uma dimensão à integração horizontal que extrapola a do simples aproveitamento de economias de escala ${ }^{78}$ dos serviços públicos de saúde.

Porém, ganhos de eficiência distributiva e, principalmente, alocativa, variam proporcionalmente com a diversidade encontrada de padrões de serviços ofertados pelos Municípios envolvidos. Pois, na medida em que cada sistema de saúde pública municipal conseguir ajustar os custos dos serviços com os benefícios efetivamente demandados pelos respectivos consumidores-eleitores, se reduz o número de Municípios sujeitos à condição de "doadores líquidos" de serviços de saúde a outros, reduzindo-se a motivação à integração horizontal formal.

\section{2. da interação dos personagens municipais com a União}

Uma variável importante na matriz de decisão das elites municipais é o equilíbrio de seu orçamento público. Se para o nosso caso, os gastos em políticas públicas de saúde são, em seu maior volume, vinculadas às transferências da União, nossa atenção então se volta para esse equilíbrio, observando onde se identificam os vínculos dessas transferências com o enfoque sobre a alocação de bens e serviços voltados à saúde pública.

O tema alocação, já abordado no capítulo anterior, costuma ser desenvolvido em pelo menos dois ambientes pela literatura: o de um estado monolítico, e o de uma

\footnotetext{
${ }^{78}$ Uma definição para economias de escala poderia ser a redução da diferença do custo de produção entre a estrutura instalada para a prestação dos serviços de saúde e a que é efetivamente requerida pela demanda dos consumidores-eleitores, dadas as especificações mínimas exigidas de ativos e mão-de-obra.
} 
estrutura federativa composta por relações verticais e horizontais, em especial, as que envolvem os Municípios com a União.

O que pudemos concluir do capítulo anterior desse confronto estrutural é o evidente papel de coordenação que caberia à União. Por outro lado, até mesmo numa visão teórica de eficiência de um estado centralizado, embora benevolente, não seria capaz de acomodar todas as interações horizontais.

Esta visão de uma tomada de decisão plenamente centralizada não se adere ao federalismo fiscal brasileiro, regrado por um contrato constitucional que divide bases tributárias e responsabilidades entre vários entes federativos ${ }^{79}$.

Observe-se que a União detém a obrigação constitucional de transferir recursos financeiros aos Estados e Municípios. Parte desses recursos pode estar vinculada a normas e, portanto, à capacidade de gasto dos Municípios, se normatizado pela União. Com isso, a União estaria em condições de corrigir e homogeneizar os efeitos das externalidades e das várias políticas de alíquotas tributárias aplicadas numa região.

Essa característica confere à União suficientes ferramentas para vincular transferências seletivas voltadas a uma determinada política pública, também a um comportamento cooperativo das elites políticas. Isso significa dizer que a União pode agir como "indutora" da formalização da cooperação entre os governos municipais em determinadas políticas públicas, inclusive, com o incentivo negativo de "penalizar financeiramente" as jurisdições que romperem com um comportamento cooperativo.

De qualquer forma, estamos atribuindo à União a responsabilidade pela coordenação, devendo acumulá-la com as de redistribuição de renda e de indução à alocação de recursos. Embora, como já observado estas últimas possam ser divididas com a estrutura regional da cooperação.

Portanto, a União poderia, além de monitorar e capturar informações, também interagir com os entes federativos, principalmente os Municípios. Poderia também

\footnotetext{
79 Além disso, um planejador centralizado não exerce qualquer interferência sobre a competição fiscal intermunicipal, pois, simplesmente, desconsidera sua existência. Ou então, não é capaz de perceber o surgimento entre os Municípios da motivação à cooperação entre eles, e, conseqüentemente, dos gastos em razão dessa decisão.
} 
induzi-los à solução de possíveis assimetrias orçamentárias ${ }^{80}$ na região, com incentivos seletivos por meio das transferências financeiras.

No capítulo anterior, falamos em mecanismos e ferramentas, tais como as transferências vinculadas às normas da União sem correlacioná-los às motivações que os indivíduos teriam em utilizá-los. Essas motivações envolvem incentivos, positivos ou negativos. Esses incentivos estariam direcionados para que as elites tomem, ou não, a decisão de cooperarem entre si na prestação de serviços de saúde, e, portanto, de também dividirem entre si o risco político-financeiro de os custos políticos desses serviços não se colarem às necessidades e expectativas dos consumidores-eleitores.

\section{3. da interação entre os personagens municipais}

Um outro aspecto interessante a se abordar como motivação ${ }^{81}$ das elites políticas municipais à cooperação é a incorporação em seus respectivos processos de tomada de decisão, seja pró ou contra a cooperação, da presunção que fazem da quantidade de bônus políticos (votos) que obteriam ${ }^{82}$.

\footnotetext{
${ }^{80}$ Afinal, qualquer redistribuição vertical a partir da União é capaz de afetar muito mais a receita tributária dos Municípios do que uma política de transferências horizontais na região é capaz de afetar a disposição da União em transferir recursos aos vários Municípios envolvidos nessas transferências horizontais de recursos na região. Por essa razão, para que ocorra o eficiente uso da ferramenta transferência financeira vertical com a redução de assimetrias informacionais, espera-se da União a captura de informações que digam respeito às motivações das elites políticas municipais à integração horizontal, estruturada ou não.

${ }^{81}$ Williamson (1986) define a motivação em três níveis: o oportunismo, a procura de interesse próprio e a obediência. A procura do interesse próprio se relaciona com a teoria neoclássica, e seria uma motivação semi-forte. A obediência seria uma motivação fraca, equivalente à procura do "non-self-interest" (interesse da autonegação). Quanto ao oportunismo, este seria a busca do auto interesse envolvendo formas sutis de engano, relacionado a uma informação incompleta distorcida, ou seja, à informação assimétrica.

${ }^{82}$ Se esta hipótese é válida, torna-se possível se arquitetar um processo de coordenação política das ações públicas de saúde na própria região, independente da ação da União.
} 
E, dependendo do quanto essa meta é mutuamente identificável entre as elites políticas de uma região, talvez possamos atrelar às elites políticas um conceito de propensão à cooperação intermunicipal, que expressaria uma combinação linear entre a integração horizontal plenamente espontânea e a totalmente induzida; de tal forma que, a partir desses dois conceitos polarizadores, pudéssemos inferir a necessidade de um esforço de coordenação pela integração horizontal, diretamente correlacionada com a propensão das elites políticas, na medida em que esta varie em grau de espontânea a induzida.

Esse esforço de coordenação poderia variar de desnecessário a plenamente externo, passando pela suficiência do interno. Ou seja, quanto mais a propensão das elites políticas à cooperação tendesse a totalmente induzida, maior seria a dependência da cooperação à coordenação externa, e, menor seria a utilidade de uma coordenação interna. E, quanto maior a propensão à integração plenamente espontânea, menor a necessidade de coordenação, inclusive a interna.

Assim sendo, a cooperação totalmente induzida seria aquela em que a negociação é conduzida por regras e metas comuns, consentidas e até impostas por uma autoridade, cuja ameaça, além de crível, quase sempre expresse em si uma "ordem" pelo compromisso das elites políticas envolvidas.

Quanto à integração plenamente espontânea, podemos entendê-la como resultante de uma negociação conduzida por um interesse mútuo entre agentes simetricamente correlacionados.

Por conseqüência, qualquer combinação linear dessas duas definições seria o resultado de negociações espontâneas, ou induzidas, realizadas com assimetria de informações, e, que por isso mesmo, necessitadas de esforços de coordenação.

Porém, a autocoordenação tem riscos. Um desses riscos pode ser encontrado em Olson (1971), a partir do qual se reconhece como racional, o comportamento de uma elite política municipal que, envolvida com a cooperação regional, busque obter o benefício coletivo sem pagar o custo de provê-lo.

Tal possibilidade impõe, quase sempre, a necessidade de alguma coordenação externa informal, e até, se possível, organizacional, voltada à obtenção desse benefício coletivo. Evidentemente, isso dependeria das motivações e interesses 
das elites envolvidas, e do quanto poderíamos distinguir as elites políticas entre si em razão de suas respectivas disposições em gastar com a cooperação.

Afinal, poderia haver, entre as elites políticas, alguma que antevisse a possibilidade de ficar com a maior fração dos bônus políticos da cooperação, e, até em razão disso, decidisse arcar com a maior parte dos gastos. Neste caso, provavelmente, a cooperação poderia ser obtida sem a necessidade de acordos, bastando os incentivos individuais, e, até mesmo, sem a necessidade de uma estrutura organizacional.

Agora, na situação em que duas ou mais elites políticas devem agir simultaneamente para a consecução da cooperação na região, torna-se necessária, ainda que tacitamente, alguma coordenação entre elas, ou mesmo, organização. Porém, ocorrendo o compromisso entre as elites políticas de compartilharem os riscos pelos resultados obtidos em conjunto, se alguma delas subestimar os incentivos, provavelmente terá um comportamento de "risco moral".

Por isso, faz-se necessário encontrar uma personagem supra municipal que exerça o monitoramento e, talvez até, a regulamentação do comportamento esperado das elites políticas, e que seja capaz de graduar os incentivos, positivos e negativos.

Talvez a União pudesse sê-la, principalmente, se suas normas forem indutoras à cooperação; até porque a União também pode assumir o papel secundário de atenuar os custos políticos de barganhas. Afinal, essas normas restringem não só as promessas de campanha das elites municipais ao campo do "possível”, como também o comportamento individual delas, na medida em que atuem observando o ambiente político institucional no qual as normatizações da União funcionam.

Porém, ainda não é esta a personagem que procuramos. Afinal, a União está afastada de todos os Municípios o suficiente para presumirmos que tenha dificuldades informacionais ${ }^{83}$ para exercer o papel de monitoramento com eficiência.

\footnotetext{
${ }^{83}$ Como curiosidade, imaginemos a União atuando como um planejador centralizado, preocupado com a eficiência distributiva em várias regiões. E, dessa forma, ao agir como um coordenador das ações de saúde pública dos Municípios, regulamentasse uma autonomia maior à burocracia de todas as estruturas regionais voltadas a sustentar a cooperação. Ainda assim, seria uma decisão ineficaz dada a assimetria informacional. Tanto que poderia ocorrer um desequilíbrio político na região com as elites resistindo às transferências líquidas a outros Municípios. E, bastaria um "não" pela transferência horizontal de recursos para significar um "não" aos compromissos pela cooperação, e à ineficiência da coordenação da União na região.
} 
Um outro possível "principal” poderia ser encontrado na própria estrutura de governança ${ }^{84}$ criada para sustentar a cooperação. Porém, se espontânea fosse, teríamos a questão de quanto poder as elites estariam dispostas a transferir à burocracia dessa coalizão, com evidentes riscos à eficiência do monitoramento desejado, em que os agentes (elites políticas) escolhem a burocracia do "principal".

Resta-nos, portanto, pensar como os consumidores-eleitores poderiam desempenhar o papel de monitores do comportamento das elites políticas envolvidas com a cooperação intermunicipal.

\subsection{1. do monitoramento das elites políticas pelos consumidores-eleitores}

De início, constata-se a dificuldade em se instrumentalizar a manifestação dos consumidores-eleitores, sendo necessário um processo representativo em Conselhos Municipais ou Câmaras Intergestoras. E, esse processo seria tão necessário quanto maior fosse o número de consumidores-eleitores residentes em uma mesma jurisdição. Afinal de contas, também seriam maiores as dificuldades de se garantir que cada consumidor-eleitor pudesse fazer uso da voz ${ }^{85}$ e acessar as informações necessárias.

Portanto, o monitoramento com a voz, seja ela plebiscitária ou representativa, expressaria o descontentamento dos consumidores-eleitores com a qualidade do serviço

\footnotetext{
${ }^{84}$ Estrutura de governança, segundo Williamson (1986), é um arranjo institucional que amenize os conflitos entre o principal e os agentes na busca de um benefício econômico mútuo. Para se reconhecerem os conflitos, ele sugere a análise de dois itens: os principais atributos dos agentes; e, os atributos básicos com respeito às diferenças dos custos de transação. As estruturas de governança diferem em suas capacidades de responder eficientemente aos distúrbios, conferidos pela racionalidade limitada e o comportamento oportunístico, geradores de incertezas. Portanto, sugere-se que as estruturas de governança assumam um caráter de especialização de modo a adquirirem uma maior sensibilidade aos custos de transação atinentes, consubstanciada num contrato entre as partes. Porém as estruturas especializadas possuem custos altos e a questão é se os custos podem ser justificados pelos seus benefícios esperados e pelo seu grau de utilização (acesso).

85

Segundo Hirschman (1970) a voz é colocada como uma alternativa à regra de saída, com os insatisfeitos forçando a melhora do serviço "fazendo barulho". Quanto maior o volume, maior tende a ser a sua efetividade em inverter o declínio da qualidade. Contudo, não pode ser tão alto que tolha o direito das elites políticas de tomarem decisão; pois, segundo o autor, a função da voz é alertar as elites envolvidas para as falhas, dando-lhes tempo de reação às pressões. Por outro lado, o mecanismo da voz é mais uníssono à medida que se reduza o número de consumidores-eleitores, daí ser preferível se fazerem representar em Conselhos ou Câmaras.
} 
público de saúde. No entanto, alguns fatores influenciam na intensidade da voz, entre eles, a existência ou não de um serviço substituto acessível, principalmente, se pensarmos na voz como uma alternativa à ameaça dos consumidores-eleitores de saída, com riscos, inclusive, de formação de sub-coalizões na região.

É por isso que o conceito de voz aplicado ao tema cooperação intermunicipal ganha interesse na medida em que a estrutura da cooperação voltada ao serviço público de saúde na região se assemelhe a um monopólio, e com isso, reduza a credibilidade da ameaça de saída dos consumidores-eleitores, e, portanto, das respectivas elites políticas envolvidas.

Colocando de uma outra forma, se considerarmos que a propensão a se afastar dos serviços públicos ofertados pela estrutura da cooperação é maior naqueles consumidores-eleitores mais conscientes da qualidade, então, na medida em que estes alcançassem outras opções, haveria uma tendência à uniformização de algumas características dos que permanecem demandando serviços dessa estrutura. Evidentemente, seria possível identificar sua maioria como formada por aqueles que não querem sair; ou, por aqueles que desejam sair, mas têm dificuldades em fazê-lo, pois não encontram uma outra opção de serviços de saúde fora do sistema público ofertado pela estrutura de cooperação criada ${ }^{86}$.

Afinal, estes consumidores-eleitores, embora permaneçam como "demanda cativa" de serviço público de saúde ofertado, quer seja pelo Município, quer seja pela estrutura de cooperação (daí a alusão ao monopólio em parágrafo anterior), acabam tendo diferentes graus de descontentamento, o qual expressam com um volume na voz que se "alimenta" da própria inelasticidade da demanda, ou, da falta dessa oportunidade de sair.

Portanto, se as elites políticas e, eventualmente, a burocracia dessa estrutura de cooperação, forem pouco sensíveis à saída dos consumidores-eleitores, a tendência é a de que aqueles mais conscientes da qualidade e mais acessíveis a opções alternativas

\footnotetext{
${ }^{86}$ E, é também até por essa razão, que esses consumidores-eleitores remanescentes deveriam ter as suas percepções da qualidade dos serviços de saúde pública prestados incentivadas com a possibilidade de se fazerem representar em Conselhos e Câmaras Municipais.
} 
se desloquem para outras fontes de prestação de serviços, provocando, pelo menos, dois efeitos.

Um primeiro seria a redução do gasto com a saúde pública, reduzindo pressões sobre receitas próprias para o financiamento do sistema ofertado de saúde pública, enquanto aumenta potencialmente o custo político de se manter ou constituir uma estrutura de cooperação, na medida em que se amplia o número de consumidoreseleitores não dispostos a se compromissarem com ela.

O outro efeito advém do fato de que os consumidores-eleitores mais sensíveis à qualidade dos serviços são aqueles que saem do sistema de serviço público ofertado, suscitando uma redução na eficiência do monitoramento dessa qualidade pelos que permanecem demandando do sistema.

\subsection{2 das diferenças entre os grupos de consumidores-eleitores}

Uma outra análise interessante é que os grupos de consumidores-eleitores tomados pela jurisdição de suas residências, assim como as elites políticas, também possuem assimetrias comportamentais, quando tomados pelo comportamento comum observado em suas respectivas maiorias.

Da mesma forma, se essas diferenças comportamentais podem ser identificadas entre as preferências das respectivas maiorias, as quais se compõem a partir de aleatórias funções utilidade individuais, então, poder-se-ia esperar dos vários grupos diferentes propensões a uma decisão coletiva pela integração horizontal, ou não.

De qualquer forma, abre-se espaço para uma classificação dos grupos em razão da variação observada nas suas respectivas propensões a essa tomada de decisão coletiva. Assim sendo, optamos por adaptar a classificação de grupos encontrada em Olson (1971). Essa classificação se faz em quatro tipos comportamentais distintos: monopsônico, privilegiado, intermediário e latente.

O chamado grupo de comportamento monopsônico visaria somente para ele, com a estruturação de uma cooperação, um benefício não previsto entre as necessidades coletivas da região. Muito provavelmente, a elite política correspondente tomaria 
decisões individuais, sem qualquer vínculo com os anseios coletivos dos demais Municípios, praticamente inviabilizando qualquer ação de coordenação regional, ou então, exigindo um desproporcional esforço nesse sentido.

Haveria também os chamados grupos privilegiados, que identificariam entre os benefícios coletivos, algum que já lhe seria ofertado diretamente por seu sistema municipal. Neste caso, se houver demanda excedente, o Município privilegiado teria um incentivo a provê-lo aos demais, conquanto os demandantes participem do ônus de sua produção. Neste caso, dependendo da extensão desse beneficio, poderia até nem haver necessidade de coordenação ou de organização entre as elites políticas envolvidas.

Um outro tipo de grupo de consumidores-eleitores seria o "intermediário", o qual não pode suprir sozinho uma certa parcela do benefício desejado coletivamente com a estrutura municipal existente, mas, também, não encontra outro com oferta excedente. Neste caso, a complementação da oferta entre eles já exigiria alguma coordenação ou organização para a sua provisão.

Um último tipo de grupo de consumidores-eleitores seria o chamado "latente". Situado em Municípios com reduzida ou nenhuma capacidade de provisão, e, portanto, com forte demanda reprimida por serviços públicos de saúde. Além disso, também se caracterizaria por ter a maioria de seus consumidores-eleitores residentes sem incentivos para a produção do serviço público de saúde isoladamente.

O grupo "latente" também se distingue dos demais pelo fato de que, se algum dos outros grupos de consumidores-eleitores votar pela sua não incorporação à estrutura de cooperação, isso em nada afetaria o seu "status quo", e, portanto, pouca razão teria para reagir com a voz. E, além disso, a sua eventual ameaça de saída de uma cooperação estruturada seria pouco crível pelos demais grupos envolvidos.

O motivo de realçarmos a observação no parágrafo anterior é que, potencialmente, os consumidores-eleitores que pertencem ao grupo "latente" não estariam em condições de um esforço contributivo face às necessidades de custeio do serviço público de saúde. Portanto, esse grupo, como um todo, necessitaria de um incentivo externo, que pode ser tanto positivo, quanto negativo. Observe-se que esse incentivo é necessário não somente para que os Municípios "latentes" possam se 
adequar a qualquer estrutura de cooperação na busca dos benefícios coletivos pretendidos, mas também para que os demais possam aceitá-lo entre eles.

\section{3. o tamanho da cooperação}

Uma correlação lógica que poderia ser testada é quanto maior for o número de Municípios na região, maior será o esforço de coordenação, maior a necessidade de regras $^{87}$ autocoercitivas, e, portanto, maior a dificuldade de se estruturar a cooperação. Neste caso, poderia até não ser necessário que todos os Municípios da região estivessem organizados em cooperação, mas sempre será necessário que aqueles que estão em condições de prestar os serviços participem dela. De qualquer forma, em geral, a cooperação ocorre entre vários agentes quando estes buscam uma meta em comum.

Para isso, os Municípios deveriam estruturar a cooperação por meio de um contrato, formal ou não, no qual possam expressar o cálculo de otimização que cada um deles faz da cooperação, evidentemente, sujeitos à satisfação do interesse mútuo ou coletivo. A necessidade do contrato se correlaciona indiretamente com a segurança dos envolvidos em relação à percepção da "justa medida" que cada um faça do retorno proporcional ao esforço e ao compromisso empenhado.

\footnotetext{
87 Segundo Olson (1971), haveria pelo menos três fatores independentes, mas cumulativos, que podem impedir que as elites políticas organizadas para a cooperação em uma dada política pública, promovam seus próprios interesses, em detrimento do coletivo, sem a existência de regras autocoercitivas. Primeiro, (a fração do ganho individual) quanto maior o grupo, menos a fração do bônus político que cada elite fará jus, menores seriam os incentivos a cooperar, e, portanto, maior a probabilidade de não se atingirem com eficiência os objetivos coletivos desejados. Segundo, (a participação desproporcional no custo e no bônus político) da mesma forma, também seria menor a probabilidade de que algum sub-grupo regional ganhasse suficiente bônus político para compensar os custos de se prover até mesmo uma parcela do beneficio previsto. Em outras palavras: quanto maior o número de participantes envolvidos na cooperação regional, menor tende a ser a formação de sub-grupos oligopolistas de maior capacidade de oferta de serviços, os quais poderiam ajudar a obtenção dos benefícios planejados. E, o terceiro fator (os custos da organização), diz que quanto maior o número de Municípios envolvidos, maior será o custo de cooperar, e, portanto, maiores as dificuldades de se obter o beneficio desejado. Em suma, quanto maior o número de Municípios envolvidos, maior a necessidade de regras autocoercitivas e de incentivos externos à organização da cooperação.
} 
Quanto menor essa percepção, maior seria a necessidade de que as regras fossem autocoercitivas, e, portanto, maior a formalização do contrato. Até como incentivo à participação de um dado Município no processo de integração horizontal, na medida em que se sinta confiante de que o esforço será dividido por todos; afinal, infere-se que a prestação do serviço dependerá do comportamento de cada Município envolvido ${ }^{88}$.

Por outro lado, antes que ocorra a decisão coletiva dos Municípios pela estruturação da cooperação, há algumas decisões tomadas Município a Município, na medida em que cada um deles atribua uma avaliação própria do beneficio esperado pelo serviço a receber da coalizão.

E, a partir dessa avaliação, seria possível se prever que um serviço coletivo seja prestado por uma estrutura de cooperação sem que esta exerça coerção para que seja remunerada, desde que o beneficio total obtido por todos os Municípios exceda o custo total; e, os benefícios obtidos por cada um deles sejam também maiores que os obtidos com relação aos seus respectivos sistemas de serviços públicos individuais.

Porém, essa avaliação fica mais insegura quanto maior o tamanho do grupo em numero de consumidores-eleitores, ou, em número de Municípios a fazerem parte de uma estrutura voltada à cooperação.

Afinal, quanto menor o tamanho do grupo, menor tende a ser a necessidade de regras coercitivas para sustentar a cooperação, na medida em que cada componente, seja Município, ou consumidor-eleitor, possa receber uma parcela mais substancial dos benefícios totais, simplesmente porque o total estaria sendo dividido por um número menor de integrantes. Ou seja, quanto menor o grupo, maior a confiabilidade de que os esforços e resultados serão eficientemente divididos.

Portanto, quanto maior for o grupo, menor seria a fração de benefícios destinada a cada componente, e assim o incentivo à prestação de um serviço coletivo

\footnotetext{
${ }^{88}$ Embora pouco provável, seria possível encontrar algum deles disposto a custear a provisão de uma certa quantidade de serviço a toda uma região, se percebesse que seu benefício individual esperado excederia o custo em fazê-lo. De qualquer forma, em razão da racionalidade, esperamos que a decisão de participar de uma coalizão dependa da relação custo/beneficio que cada Município faria. Cada um deles arcaria com uma parcela dos custos da produção do serviço coletivo, desde que os benefícios da parte que ele usufruir deste serviço excedam o custo incorrido.
} 
seria também menor. E, além disso, a partir da própria definiçãa de serviço coletivo, uma vez disponibilizado, não haveria como se impedir que componentes que não tenham contribuído por ele usufruam o serviço, em razão de o acesso ser universalizado a todos os consumidores-eleitores dos grupos envolvidos.

Assim sendo, há uma tendência de que a quantidade prestada de serviços públicos de saúde por uma qualquer estrutura de cooperação seja sub-ótima, quanto menor for a parcela dos benefícios percebida pelo envolvido que já receba a maior delas.

Portanto, quanto maior o número de envolvidos, que resulte em parcelas de benefícios menores, menor é o incentivo à cooperação em relação aos Municípios envolvidos, ou do Município em relação aos respectivos consumidores-eleitores, em prover coletivamente o serviço público de saúde. Reduz-se, então, a quantidade e/ou qualidade do serviço prestado. E, no limite, pode-se inferir que quaisquer grupos com um grande número de componentes terão dificuldades em obter uma decisão de se produzir coletivamente um determinado serviço público, e, portanto, de agirem cooperativamente $^{89}$.

Uma evidência empírica a ser identificada refere-se a uma outra inferência que fazemos a partir da teoria de que há uma correlação entre o tamanho dos grupos jurisdicionais de consumidores-eleitores e a quantidade de grupos, com a possibilidade de se constituir uma estrutura de cooperação, ou mesmo, com a mortalidade das que se formaram $^{90}$.

\footnotetext{
${ }^{89}$ De certa forma, esta digressão lógica vem de encontro com a informação extraída da Tabela II (terceiro capítulo), de que, em 1997, o número médio de Municípios envolvidos nos 109 consórcios intermunicipais existentes no país era 12, sendo que a população média de cada um desses Municípios não passava de 16.500 habitantes. Essa evidência fica ainda mais marcante, se tivermos em conta que o consórcio mais antigo do país, o da região de Penápolis, no Estado de São Paulo, possuí 7 Municípios com uma população média inferior a 9.000 habitantes.

90 Inclusive, North (1990) cita o tamanho do grupo entre as dificuldades de uma ação coletiva, colocando-o ao lado dos custos de monitoramento, dos custos de coerção e da assimetria entre os personagens.
} 
Por outro lado, encontramos Olson (1971) citando pelo menos três fatores ${ }^{91}$ distintos, mas, acumulativos, que impedem os grandes grupos de realizar integralmente o seu interesse comum. O primeiro diz que quanto maior a estrutura criada para a cooperação, menor a fração do bônus total que receberá cada envolvido que atue pelo interesse de uma cooperação intermunicipal. Ou seja, cada envolvido considerará a recompensa ao esforço individual pela ação coletiva cada vez menos adequada, e, com isso, a estrutura da cooperação se afasta ainda mais do ponto ótimo para o beneficio coletivo esperado, se é que alguma vez conseguiria atingi-lo.

Segundo, e até como uma conseqüência do anterior, se quanto maior fosse a estrutura da cooperação, e, portanto, menor a parte do bônus total que caberia a cada envolvido ou a qualquer parte dessa estrutura, então, menor seria a possibilidade de alguma parte dessa estrutura, e muito menos de algum ente envolvido, ganhar uma participação no bônus total com a obtenção do benefício coletivo que compensasse os respectivos custos incorridos em prover até mesmo uma pequena quantidade do benefício. Ou seja, quanto maior for a estrutura da cooperação, menor será a probabilidade de interação oligopolista entre alguns dos Municípios envolvidos que poderia ajudar a todos na obtenção do beneficio coletivo esperado.

E, em terceiro, quanto maior for o número de Municípios envolvidos na estrutura de cooperação regional, mais custosa (financeiros e de transações) seria a organização da cooperação, e, portanto, mais alta seria a barreira a ser vencida antes que qualquer quantidade do beneficio coletivo possa ser obtida.

Por essas razões, quanto maior for o número de componentes de qualquer grupo que pretenda se organizar para qualquer objetivo comum, e, portanto, para agir cooperativamente, menor será a confiabilidade de sucesso sem alguma coordenação externa. Ou seja, quanto menor o grupo, mais espontânea tende a ser a cooperação, e menos necessidade de coordenação externa é requerida. E, quanto maior o grupo, maiores os esforços para induzir a cooperação, e maiores são as necessidades e esforços de uma coordenação externa.

\footnotetext{
91 Basicamente, os três fatores são a fração do ganho individual; a participação no custo desproporcional aos ganhos; e, os custos da organização.
} 
Ao longo desta subseção, evidenciamos basicamente a influência do tamanho do grupo na motivação à cooperação de seus envolvidos. Evidentemente, quanto maior o tamanho dos grupos, maiores dificuldades terão na provisão do beneficio coletivo esperado de forma espontânea, baseado somente em regras "autocoercitivas". Logo, "necessitam" de alguma coerção e de incentivos externos, ainda que seja para se organizarem na provisão de um benefício coletivo esperado.

\section{4. a literatura de apoio ao tema}

A literatura de apoio a que nos referimos é a que nos fornece sustentação teórica à análise do tema proposto. Neste capítulo, em especial, a teoria de escolha coletiva $^{92}$.

Em termos de literatura aplicada, fazemos uso dos estudos de federalismo fiscal, em especial, os que tratam da integração horizontal motivada pela formação da Comunidade Européia, que, inclusive, tem características confederativas ${ }^{93}$, ou seja, trata-se de uma coalizão entre países induzida pelo Tratado de Maastrich $^{94}$.

\footnotetext{
92 A escola da escolha coletiva recebe algumas críticas. Uma dessas críticas mostra que o processo coletivo pode conduzir a uma situação pior, na medida em que se sujeite aos conflitos de interesse entre os grupos. E, além disso, a decisão coletiva poderia não ser mais do que o resultado agregado de várias individuais. Em defesa, não nos esqueçamos de que os conflitos são atinentes ao processo democrático de decisão, e que até podemos decidir pela manutenção do "status quo", desde que seja essa a vontade da maioria dos consumidores-eleitores do grupo. E, coletivizar as diversas racionalidades individuais ajuda a minimizar o efeito de "caronistas" no processo, embora facilite a sua ação.

93 estrangeiros, formam um só, reconhecendo um chefe em comum para essa finalidade. Também se define pela aliança de Estados ou nações para um fim comum em relação a terceiros, em geral, político-militar. Enquanto isso, a federação é a união política entre Estados ou nações, para a qual todos transferem parcelas de poder e soberania a um novo ente a fim de que este aja interna e externamente.

94 O Tratado de Maastrich obedece aos princípios de uma confederação, estabelecendo critérios de convergência, notadamente no setor monetário. Seus protocolos estabelecem metas e punições, embora admita desvios desde que mantida a tendência acordada. Pelo tratado, os Estados membros da Comunidade Européia continuam a conduzir com relativa independência as próprias políticas públicas, conquanto se mantenham dentro dos critérios pré-estabelecidos pelo tratado. As suas regras de exclusão podem ser agrupadas conforme a ótica de quem as observa. No que se referir à iniciativa de afastar-se do Tratado, representa de imediato uma "declaração de guerra" a todos os demais Estados membros. Quanto à situação em que um determinado Estado membro se afaste dos limites, impõem-se que a exclusão seja temporária.
} 
Além disso, procuramos na literatura, algum modelo que ao final de seu desenvolvimento pudéssemos considerar os efeitos dos incentivos da União sobre as motivações à tomada de decisão das elites políticas. Esse modelo também deveria considerar que as elites políticas, embora tomadoras individuais de decisão, o fizessem na condição de representantes eleitos dos respectivos grupos de consumidores-eleitores.

Nesse sentido identificamos o mecanismo ${ }^{95}$ político-eleitoral de Dixit e Londregan (1998), o qual adaptamos à situação em que algumas elites políticas municipais ${ }^{96}$ devam tomar uma decisão entre duas posturas ideológicas: pró, e contra, participar da estruturação de uma cooperação regional, a partir de um resultado eleitoral desta questão em meio a um grupo jurisdicional de consumidores-eleitores.

Essa decisão eleitoral se daria por uma regra de maioria democrática, expressando uma combinação linear de várias decisões individuais numa coletiva. $\mathrm{O}$ resultado desse consenso é obtido de um processo ${ }^{97}$ político organizado, sobre como, por quem e quais os padrões de serviços públicos que deveriam ser ofertados.

Esse resultado de consenso sinalizaria às elites políticas a tomada de fato da decisão. Ressalte-se que, em razão de a tomada de decisão das elites políticas se correlacionar com a do correspondente grupo de consumidores-eleitores, dever-se-ia atribuir a esses grupos monitorar a ação pública dos representantes. Possível, a partir dos critérios de "voz" já discutidos anteriormente.

Agora, na adaptação desse modelo, devemos prever a possibilidade de que a decisão coletiva dos consumidores-eleitores possa ser influenciada individualmente.

\footnotetext{
95 Evidentemente, para que isso seja possível, é necessário que se considere como dado, que as elites políticas municipais possuam recursos e ferramentas suficientes para adaptar seus sistemas de alíquotas tributárias aos interesses dos consumidores-eleitores, interesses que se expressaram coletivamente segundo alguma regra de maioria.

${ }^{96}$ Observe-se que, por se tratar das elites políticas, ainda interferem nesse mecanismo as seguintes variáveis, entre outras: as motivações delas em transferir recursos à estrutura voltada à cooperação intermunicipal e ao comportamento oportunístico; a necessidade do equilíbrio de gastos e receitas conjugada com a resistência delas em permitir que surjam custos políticos com a ampliação de alíquotas tributárias, cujo acréscimo de receita corresponderia ao gasto na cooperação; e, a influência da vontade da maioria dos consumidores-eleitores;

97 O processo de escolha coletiva pode ser visto como uma extensão do modelo de maximização da utilidade aplicado a um consumidor-eleitor mediano. Esse processo depende dos arranjos políticoinstitucionais e das regras do processo de decisão adotadas que garantam a cada consumidor-eleitor o mesmo poder de influenciar os resultados da decisão coletiva.
} 
Para isso, deve-se prever o uso de incentivos. Isso "per si" já indica que esses incentivos sejam seletivamente percebidos como positivos ou negativos pelos consumidores-eleitores, a fim de que se minimize o risco de não "votarem" eficientemente, se são a favor ou contra a organização da cooperação.

Finalmente, admitiremos que as elites políticas, embora façam promessas de campanha a seus consumidores-eleitores, se preocupem com o bem estar da maioria, com os limites orçamentários e com os compromissos assumidos, e, portanto com quaisquer alterações nos parâmetros ${ }^{98}$ que causem custos políticos. Por isso mesmo, também estariam preocupadas e tomar decisões individuais voltadas a satisfazer a maioria dos consumidores-eleitores.

\section{5. a existência de desigualdades entre os Municípios}

No transcurso deste trabalho várias hipóteses estão sendo abordadas, até mesmo pela diversidade de variáveis explicativas à cooperação intermunicipal. No entanto, referentes aos Municípios, algumas ganham proeminência, as quais trataremos amiúde nesta seção.

Com relação específica aos Municípios, se os aceitarmos como agentes inteiramente iguais, envolvidos com o mesmo objetivo comum de integração horizontal para a prestação de serviços públicos de saúde, pouco haveria o que considerar sobre o grau da descentralização da tomada de decisão regional da política pública de saúde, pois, esses entes federativos possuiriam e fariam uso de seus poderes independentemente. Além disso, pouco haveria a falar sobre as necessidades de coordenação, ou mesmo de contrato formal, pois sendo iguais, minimizada estaria a

\footnotetext{
${ }^{98}$ Os parâmetros nos quais as elites políticas presumiriam a existência de custos políticos referem-se muito mais às resistências de consumidores-eleitores a qualquer ampliação do nível de gastos voltados a determinada política pública. Inclusive, essa resistência pode se dar mais em razão dos efeitos de complementariedade percebidos, do que pelo incremento de alíquota tributária. O que, de certa forma, também explicaria a fraca disposição das elites municipais em tributar bases próprias, até porque podem suprir seus orçamentos voltados à saúde pública com as transferências verticais a partir da União.
} 
assimetria informacional, com o comportamento de uns podendo ser tomado pelos de outros.

Ou seja, esta hipótese simplificaria o modelo a ponto de podermos analisar as motivações das elites políticas na busca do equilíbrio alocativo na região ${ }^{99}$, na medida em que considerarmos que as elites políticas tomam decisões a partir somente dos resultados eleitorais que revelam se os respectivos grupos decidem coletivamente pró e contra cooperar.

Por outro lado, embora o contrato constitucional ${ }^{100}$ sustente esta hipótese, ainda assim, esta seria uma hipótese fraca, pois, em geral, os Municípios de uma região apresentam diferentes capacidades na disponibilização de recursos entre si.

Inclusive, do capítulo anterior, podemos trazer a conclusão de que a competição fiscal, municiada pela gestão de políticas de alíquota tributária, afeta não somente a disposição das elites políticas ao gasto em uma estrutura de cooperação, como também afeta o comportamento delas de se adequarem às normas que regulam as transferências financeiras da União, e, por consequiência, expressam tendências a comportamentos divergentes entre elas.

Afinal de contas, as elites políticas municipais devem se dispor às transferências horizontais de recursos, as quais variando em grau, alterariam a dependência por receitas próprias. Ora, havendo a necessidade de diferentes transferências líquidas entre os Municípios, é de se esperar que os conflitos de interesses fiscais na região, advindos dessa assimetria, inibam a cooperação, se não houver algum esforço de coordenação.

O resultado disso é que devemos não considerar os Municípios totalmente iguais. Podem até sê-lo sob o aspecto constitucional, no entanto, não o são sob o aspecto econômico.

Essa constatação, por outro lado, tem efeitos sobre a União também. Afinal, ratifica a necessidade de que ela minimize as assimetrias, a fim de proporcionar a si

\footnotetext{
${ }^{99}$ E, portanto, da equalização e coordenação de receitas e gastos fiscais à política pública de saúde na região.

100 A CF 88 atribui a cada ente federativo a autonomia administrativa e tributária e iguais capacidades políticas de decisão.
} 
mesma as condições para uma maior eficiência na colocação seletiva de incentivos prócooperação por meio de transferências financeiras verticais. Além disso, se aceitarmos a hipótese de que a mobilidade dos consumidores-eleitores e de seus fatores de produção "sustenta" a competição tributária, então se exigem da União, no que diga respeito à saúde pública, normas regulamentadoras.

Uma outra hipótese importante é a de que os personagens coadjuvantes (elites políticas, e consumidores-eleitores), enquanto indivíduos, têm racionalidade limitada. O interessante é que se incluíssemos a União entre os personagens, enquanto ente tomador de decisões, também teria a sua racionalidade limitada pela assimetria informacional.

Quanto aos consumidores-eleitores e às elites políticas, a racionalidade limitada se justificaria das diferentes percepções sobre os efeitos da competição tributária e das externalidades, e de como cada um deles reagiria a elas, principalmente, os consumidores-eleitores com a sua própria mobilidade e a de seus fatores.

Especificamente quanto às elites políticas municipais, admitiremos nas suas funções utilidade que no transcurso de seus mandatos políticos estariam dispostas à otimização dos recursos por meio da cooperação intermunicipal, variando entre elas o grau dessa disposição, na medida em que as suas motivações em fazê-lo também variarem $^{101}$.

Além disso, elas também seriam motivadas à tomada de decisão pela presunção que fazem da quantidade de bônus políticos (votos) que obteriam com a decisão e o seu resultado, depois de implementada.

Também, estariam preocupadas com o bem estar da maioria; no entanto, sujeitas aos limites orçamentários e aos compromissos assumidos. E, além disso, estariam cientes de que quaisquer alterações nesses parâmetros causam custos políticos. Nesse caso, as necessidades das minorias seriam atendidas na medida em que a maioria assim se dispusesse, o que não dispensa algum interesse político-eleitoral da elite em propor incentivos seletivos que minimizem a exclusão social delas nos grupos jurisdicionais de consumidores-eleitores.

\footnotetext{
${ }^{101}$ Por exemplo, a necessidade ou não de se ampliar receita tributária própria influencia a disposição dos personagens em alterar o padrão de gastos de saúde pública voltados à coalizão intermunicipal.
} 


\section{6. as características de uma integração horizontal}

Em geral, a integração horizontal envolve a negociação entre pessoas de direito público politicamente iguais, embora cada uma deles com diferentes capacidades e interesses de custear com recursos próprios sua participação em ações coligadas. A integração pode ser motivada tanto pelas externalidades, quanto pela otimização das estruturas existentes. Evidentemente, a mobilidade interjurisdicional de consumidores-eleitores e de fatores é necessária.

Vimos no capítulo anterior que a política de alíquotas tributárias é o instrumento que correlaciona inversamente a competição tributária com a cooperação, na medida em que as elites usam dela para atrair, manter, ou repelir investimentos, ou ainda, para aumentar gastos.

Por isso, parece-nos evidente que o desenvolvimento de um ambiente favorável à cooperação regional necessita de elites políticas motivadas e compromissadas em cooperar o suficiente, para que se sintam motivadas a inibir a competição tributária na região, na medida em que esta é um comportamento não cooperativo $^{102}$.

Assim sendo, admitiremos que as motivações das elites políticas refletem a decisão coletiva de seus respectivos grupos de consumidores-eleitores. E, se as elites políticas tomam suas decisões em nome dos Municípios, então, por associação, os consumidores-eleitores, enquanto representados pelas elites políticas, tomam também decisões coletivas pelos respectivos personagens centrais, os Municípios ${ }^{103}$.

\footnotetext{
${ }^{102}$ Um enfoque desprezado pela visão normativa da teoria tradicional, na medida em que os Municípios são vistos como receptores líquidos em potencial de transferências, vinculadas ou não, ainda que tenham estruturas tributárias próprias.

${ }^{103}$ Quando esses personagens coadjuvantes tomam suas decisões, embora de racionalidade limitada, os presumimos conscientes de que o fazem em nome de pessoas de direito público. E que, por isso mesmo, estão conscientes da necessidade de que regras de acesso e de exclusão aos serviços a serem prestados pela estrutura de cooperação tenham características próprias, bem como sabem da necessidade de um arranjo institucional que coordene e maximize o aproveitamento coletivo dos recursos.
} 
Portanto, com esse desenho, descrever a cooperação intermunicipal passa a envolver algumas variáveis explicativas, dentre as quais citamos: a mobilidade, o ambiente de tomada de decisão, a motivação e compromisso, a competição fiscal e externalidade, o gasto e a receita pública, o arranjo institucional e as questões alocativas e redistributivas.

Especificamente quanto à mobilidade, ela foi descrita no capítulo anterior, principalmente quando abordamos o mundo de Tiebout, onde um indivíduo escolhe o seu padrão de serviço sujeito a uma restrição orçamentária representada por um custo de transporte, que é graduado a partir de um valor zero.

Por outro lado, a literatura aplicada sobre a integração européia analisa a mobilidade sob o aspecto da ruptura de barreiras à sua possibilidade, de modo que os indivíduos possam também acessar o seu padrão desejado de serviços.

De qualquer forma, em ambos, fica evidente a correlação entre a intensidade da competição tributária e o grau de mobilidade dos consumidores-eleitores e de seus fatores de produção. Tal constatação impõe à organização que pretenda coordenar uma integração horizontal a observação do grau de mobilidade em suas ações regionalizadas.

Além disso, é possível atrelarem-se à competição tributária outras variáveis: a política de alíquotas tributárias, o ambiente político e os custos políticos. Afinal, um choque de alíquotas influencia os custos marginais dos fatores, os orçamentos públicos e a disposição aos gastos. Por conseqüência, influi na eficiência da oferta de serviços públicos, que se agrava com a "retaliação", quase sempre sem vantagem competitiva, ampliando o custo político de se estruturar a cooperação.

Quanto aos custos políticos, como já observado, a sua existência sugere assimetrias, as quais com certeza se desenvolvem no âmbito da racionalidade limitada, dada a diferença de avaliação que as elites e os consumidores-eleitores fazem da incerteza $^{104}$ e do risco de se aderir ou não à cooperação.

\footnotetext{
${ }^{104}$ A incerteza advém da racionalidade limitada e da possibilidade de comportamentos oportunísticos entre os envolvidos em cooperar. Williamson (1986) propõe vários tipos básicos de incerteza: a primária, dependente das condições ambientais; a secundária, em razão da falta de comunicação ou por estar indisponível total ou parcialmente entre os envolvidos; e, acomportamental, advinda de um
} 
Essas incertezas estão na possibilidade de alterações da política de alíquotas tributárias de cada Município envolvido, que poderia afetar os gastos em cooperar, inclusive, quando se consideram os aspectos de complementariedade entre as políticas públicas.

Além disso, também é possível encontrar algumas fontes de incertezas na previsão dos resultados em cooperar; ou seja, se estes seriam percebidos ou não pelos consumidores-eleitores como os esperados. Afinal, sejam quais forem as causas dessas assimetrias, incluindo as proporcionadas pelas várias incertezas advindas de se estruturar a cooperação, elas poderão ter seus efeitos minimizados, e, portanto, seus correspondentes custos políticos também minimizados, com as mesmas cláusulas auto coercitivas já mencionadas, e que regram a forma de pagamento das cotas parte e as condições de acesso, exclusão e reinclusão.

De qualquer forma, destaca-se ao longo deste capítulo, que uma das características mais importantes da integração horizontal é a correlação desta com as variáveis motivação e compromisso das elites políticas. Estas variáveis além de envolverem incentivos às elites políticas municipais a se coligarem e dividirem o risco político-financeiro dos resultados provenientes da cooperação, basicamente, elas se desenvolvem a nível municipal num "trade-off" entre a decisão coletiva dos consumidores-eleitores e a decisão individual da elite política correspondente.

Ainda no campo das motivações, devemos também manter as hipóteses da teoria tradicional de finanças públicas, vinculando a eficiência de um processo de coordenação horizontal aos resultados da internalização das externalidades e à otimização das estruturas existentes na região. Por outro lado, novamente chamamos a atenção ao fato de que, embora a perspectiva dessas hipóteses incentive a cooperação intermunicipal, a teoria tradicional não prevê a necessidade de um arranjo institucional que maximize esses resultados.

\section{7. aspectos sobre os gastos públicos voltados à estruturação da cooperação}

premeditado comportamento estratégico, um "blefe", quer seja como mecanismo de revelação, quer seja no desenho dos contratos. 
Quando pensarmos no sistema ${ }^{105}$ de alíquotas tributárias, não poderemos ignorar a existência dos custos políticos, e, portanto, a existência de uma estrutura política. Assim sendo, também não devemos nos esquecer de tratar da estrutura política, se quisermos controlar os custos políticos.

Em geral, a estrutura política é influenciada por pressões de grupos de interesse, o que nos sugere dois aspectos. Um primeiro, que a pressão política tem mais a ver com a determinação das alíquotas tributárias e com o financiamento dos gastos públicos do que a teoria ${ }^{106}$ econômica tradicional supõe. Em segundo, que a pressão de grupos de interesses tem correlação direta com os custos políticos.

$\mathrm{O}$ que nos conduz à necessidade de uma regra ${ }^{107}$ de financiamento da cooperação mais rígida em relação à manipulação política, a qual dificulte mudanças que acarretem custos políticos associados a elas. Afinal, decidir sobre gastos voltados a

105 A teoria tradicional de finanças públicas propõe a idéia de que é possível se otimizar a estrutura de alíquotas tributárias maximizando uma função de bem estar social, que expressa as utilidades de todos os indivíduos na sociedade, evidentemente sujeita a restrições. Holcombe (1998) lembra que algumas críticas foram elaboradas a essa metodologia, destacando que "(...) essa função não considera o lado dos gastos do orçamento público, e nem as possíveis divergências entre as utilidades” . E prossegue, “(...) se quiséssemos atribuir ao sistema de alíquotas tributárias um papel redistributivo também caberiam algumas críticas, na medida em que, na busca da otimização deste sistema, ocorressem custos políticos significativos, pois todos os grupos de interesse buscam ampliar a renda transferida para eles, ou reduzir a transferida deles" .

106 A teoria tradicional atribui como motivação à alteração da política de alíquotas tributárias, as diferenças observadas nas elasticidades de demanda dos bens ou serviços que compõem a base tributária.

107 Segundo Ostrom (1986), as regras são elementos lingüísticos, conhecidos e utilizados para o ordenamento dos relacionamentos repetitivos e interdependentes. Resultariam dos esforços de um grupo de indivíduos para se atingir a ordem e a previsibilidade em situações definidas, criando punições, determinando como se entra ou sai de posições relativas, esclarecendo o que se espera, se permite, ou se proíbe, como serão divididos resultados, deles, quais são permitidos ou proibidos aos envolvidos afetar. As regras seriam os meios pelos quais intervimos e transformamos a estrutura de incentivos em situações fáticas. Elas podem ser alteradas, negociadas, "ex-ante" ou "ex-post". Têm força de prescrição quando associada a uma restrição, quer seja obrigação ou proibição; ou seja, o conhecimento e a aceitação delas leva os indivíduos não só a identificarem entre suas ações as que quebram as regras, mas também, a preverem as consequiências na medida em que os outros indivíduos possam responsabilizá-los. Observese que as leis formais podem se tornar regras quando os indivíduos se sintam responsabilizáveis por quebrá-las. Outro enfoque é como as regras são observadas. É como se a regra contivesse uma força de permissão, em oposição ao sentido de proibição dado pela força da prescrição. A intensidade da força de permissão não é unânime; pois, se correlaciona com a previsão antecipada do comportamento dos indivíduos ante a regra, ao invés de se correlacionar com situações fáticas do comportamento observadas com as mesmas regras. 
qualquer política pública envolve custos políticos, e, portanto, envolve também os gastos dirigidos à estruturação da cooperação.

Da mesma forma, também podemos pensar nos custos políticos surgidos a partir da alteração do valor das cotas de uma estrutura já existente. Afinal, quaisquer mudanças em atenção a outros grupos de interesse, incorrerão a ambos os lados custos políticos, a uns por adequá-las aos interesses de outros; e a outros, por manter o "status quo" pretendido pelos primeiros.

Porém, se as regras sobre os gastos públicos voltados a uma estrutura elaborada para consubstanciar a cooperação estiverem formatadas em um contrato, então, o custo político desse sistema tende a ser muito reduzido. Por outro lado, se o sistema é flexível e sujeito à negociação, incentivam-se alterações com os conseqüentes custos políticos ${ }^{108}$.

De qualquer forma, a literatura pouco vincula receita tributária aos gastos públicos; afinal, não é fácil se determinar o nível eficiente de produção de serviços públicos.

Da mesma forma, também não é fácil se projetar um sistema ótimo de rateio intermunicipal, sem levar em conta como essas receitas serão gastas. Inclusive essa necessária correlação entre receitas e gastos foi realçada por Buchanan (1993), quando argumentou que a “(...) combinação dos custos e benefícios dos gastos de um setor público deveria ser objeto do contrato constitucional (...)” .

Se transpusermos a afirmação de Buchanan à estruturação da cooperação intermunicipal, ela poderia justificar um compromisso dos Municípios em vincular uma parte da receita fiscal com os gastos em serviços saúde pública prestados por ela.

E, se explorássemos o comentário de Buchanan no ambiente político de tomada de decisão de uma dada elite política acerca da necessidade de alterar a política de alíquotas tributárias implementada, então, provavelmente, seríamos levados a concluir o seguinte: se o nível e a distribuição de gastos públicos, de um determinado

\footnotetext{
${ }^{108}$ Aproveitando a oportunidade de se transporem tais conceitos à provisão financeira de uma coalizão intermunicipal, inferimos que, se a respectiva regra estiver contida no contrato, então, serão limitados, não somente os custos políticos para sua manutenção financeira, mas também os custos de anuência dos consumidores-eleitores e, por conseqüência, das elites políticas municipais.
} 
Município, voltados à cooperação, forem definidos num processo de tomada de decisão por maioria simples, sem que o contrato constitutivo de sua estrutura contenha alguma restrição vinculada ao recebimento da cota parte, então, objetivando o apoio eleitoral do consumidor-eleitor mediano, essa elite política tenderia a se comportar oportunisticamente para satisfazer a maioria dos consumidores-eleitores residentes, inclusive, com a redução de alíquotas tributárias, e, consequientemente, com a redução do valor de sua cota parte a financiar a estrutura da cooperação.

No entanto, desenha-se um paradoxo. Afinal, se o tributo ("preço") incidente sobre o consumidor-eleitor mediano pode ser reduzido, então a quantidade de serviço público por ele demandado tenderia a aumentar, resultando em maiores gastos governamentais do que seria o nível ótimo determinado pelo equilíbrio orçamentário, em razão até da receita recém deprimida.

Ora, se isso é factível, então estaríamos aceitando que cada consumidoreleitor pode moldar a sua própria função utilidade "endogeinizando" o benefício esperado de serviço de saúde pública a partir da estrutura da cooperação existente, aceitando que se vincule parte da receita tributária ao gasto público, como se ele idealizasse um preço aproximado pelo serviço.

Assim sendo, somos conduzidos à seguinte conclusão intuitiva: a criação de um consenso sobre o nível de gastos públicos, que agiria como um mecanismo a conduzir o processo político na direção do nível ótimo ${ }^{109}$ de gastos públicos. E, o equilíbrio poderia ser obtido com a otimização dos recursos a nível regional, a partir da estruturação da cooperação.

Poderíamos, então, admitir que cada um dos consumidores-eleitores infere um determinado nível de satisfação com o serviço, a partir da percepção da qualidade desses serviços que cada um deles faz, demandados a partir da estrutura de cooperação

\footnotetext{
${ }^{109}$ Algo a se observar é que, se por hipótese, um Município pudesse suprir sua necessidade financeira apenas com recursos próprios tributários, então, não necessitaria de outros instrumentos tributários, tais como transferências financeiras, que distorcem a mobilização de fatores entre os Municípios. Inclusive, essa é uma das hipóteses embutidas no modelo de Tiebout, onde a receita tributária é arrecadada dos consumidores-eleitores residentes independente de qual seja o Município no qual eles tenham constituído a sua obrigação tributária. Evidentemente, por traz dessa hipótese, está a de que são regiões pequenas ou de baixa complexidade na distribuição dos fatores entre os Municípios, cujas populações tendem à homogeneização.
} 
criada. Também admitiremos que esse nível de satisfação, agregado em uma decisão coletiva, pode sinalizar às respectivas elites políticas o grau de prioridade à vinculação de parte da receita tributária com o gasto voltado à cooperação.

É interessante se abordar a tomada de decisão plebiscitária sob a ótica do chamado orçamento participativo ${ }^{110}$, como um caso empírico a ser observado nessa linha de lógica. Afinal, decisão plebiscitária, independente de qual seja a regra de tomada de decisão, parte do princípio de que os consumidores-eleitores percebem, ou, se fazem representar por quem supõem perceber, a correspondência que existiria entre a restrição orçamentária, e, portanto, indiretamente, o fracionamento das receitas disponíveis, com os benefícios esperados de um determinado gasto público.

\section{8. a complementaridade das políticas públicas entre os Municípios}

O objetivo desta seção é construção de um cenário que ilustre o papel das complementaridades à política do setor de saúde pública. A intenção é demonstrar a influência de outras políticas públicas nas decisões sobre saúde pública, e ratificar a necessidade de coordenação da integração horizontal. Trata-se de um enfoque “(...) muitas vezes negligenciado na teoria dofederalismofiscal” , segundo Persson e outros (1996).

Definimos a complementariedade como o efeito indireto de uma tomada de decisão de uma dada elite municipal sobre alguma de suas demais políticas públicas, efeito este que interfere na tomada de decisão dessa ou de qualquer outra elite política, no que concerne às ações voltadas à política pública objeto da estruturação desta cooperação regional, que, no presente caso, se refere à política pública de saúde.

Atualmente, mesmo com o advento da União Européia, não se conhece um país que tenha delegado sua política monetária a uma agência monetária supranacional, sem que, ao mesmo tempo, retivesse sua autonomia política. A mesma coisa pode-se esperar dos Municípios envolvidos na estruturação da cooperação em ações de uma

\footnotetext{
${ }^{110}$ Há as experiências de "orçamento participativo" nos Municípios de Porto Alegre e São Paulo.
} 
dada política pública. Seja qual for a política pública objeto dessa estrutura, qualquer um dos Municípios envolvidos também não delegaria a tomada de decisão de suas políticas fiscais.

Por outro lado, esse fato influencia assimetricamente cada elite política municipal em suas ações cooperativas, na medida em que ocorram assimetrias de suas respectivas políticas fiscais. Essas assimetrias teriam origem na necessidade de gastos com as demais políticas públicas, para as quais cada elite política sofre pressões de grupos de interesse diversos.

E, ainda que a influência ${ }^{111}$ de grupos de pressão atrelada a interesses de outras políticas públicas seja reduzida, esses grupos de pressão podem passar a exercêla sobre a política de alíquotas tributárias, para que se mantenha o volume de gastos destinados às políticas públicas de seus interesses, ampliando a competição físcal e de seus efeitos inibidores à cooperação, na medida em que se ampliem as variações entre as alíquotas tributárias municipais na região.

É por isso que o movimento na direção de se estruturar alguma forma de cooperação intermunicipal deve ser de algum modo "pressionado". E, se for a intenção dos envolvidos que a estrutura de governança resultante dessa cooperação assuma um estilo federativo, essa "pressão" deveria emergir do próprio grupo constituinte, em razão da necessária regra de maioria absoluta na tomada de decisão.

Além disso, deve ser mais fácil obter e manter a estrutura de cooperação intermunicipal adotada, desde que, ainda na sua formação, cada elite política envolvida se expresse muito mais pela vontade coletiva do respectivo grupo de consumidoreseleitores, do que pela maioria revelada na região como um todo. Isso parece o óbvio, mas seria a forma de se atribuir à estrutura adota para a cooperação, a necessária legitimidade para exercer um papel coercitivo sobre os Municípios envolvidos, resistindo às pressões de grupos de interesse ligados às outras políticas públicas.

\footnotetext{
111 Por outro lado, os efeitos da complementariedade sobre as políticas de saúde pública estão se alterando dentro da estrutura federativa brasileira pois, com a vigência da Emenda Constitucional n..$^{\circ} 29$, estabeleceu-se, entre outras coisas, que a participação dos gastos em saúde pública na receita própria será de pelo menos $15 \%$ a partir do ano de 2004, em todos os Municípios brasileiros.
} 
Autores como Persson e outros (1996) chamam a atenção para o risco de uma grande concentração regional, que poderia ocorrer a partir da estruturação de uma cooperação, ainda que unicamente voltada à saúde pública. Essa concentração poderia se dar pela abrangência ampliada desta estrutura a outras políticas públicas na região, dada a complementaridade delas. Em razão deste risco, justifica-se que a estrutura desenhada para a cooperação em política pública de saúde tenha uma estrutura de governança com salvaguardas contra o excesso de concentração de poderes nela.

Na mesma linha de raciocínio, o sucesso de uma estrutura de cooperação também poderia incentivar alguma outra forma de estrutura suplementar, enfraquecendo a oposição política municipal contrária à utilização desse processo de cooperação intermunicipal a outras dimensões políticas. Por outro, também poderíamos ter um efeito benéfico de segunda ordem com a ampliação do custo de saída dos Municípios envolvidos ${ }^{112}$.

A idéia de complementaridade ainda traz uma outra implicação: o perigo de divisibilidade dos Municípios da região em grupos de opinião podendo cindir e desfazer a estrutura criada para a cooperação. Por exemplo, algum Município da região que tenha ficado "de fora" da estrutura montada, algum do tipo "monopsônico" que perceba ameaçada a sua hegemonia política na região, passa então a comportar-se oportunisticamente, a fim de que os gastos e benefícios da estrutura de cooperação sejam postos em dúvida pelos Municípios que aderiram a ela. Evidentemente, neste caso, reforça-se a necessidade de uma entidadesupra-municipal no papel de coordenação dessa integração horizontal.

Se qualquer reversão parcial no processo de estruturação da cooperação reduz os custos de saída, então, um cenário onde os benefícios da cooperação fiquem aquém do esperado, ainda que parcialmente, reforçaria o argumento daquelas elites políticas que criticam qualquer coisa vinda dessa estrutura. Isto reduz a disposição dessas elites à livre mobilidade, incentivando-as a desenvolver barreiras de acesso em seu Município

\footnotetext{
${ }^{112}$ Se admitirmos que há uma relação inversamente proporcional entre a intensidade do custo de saída e o grau de consenso na tomada de decisão, então, qualquer ameaça de saída de algum Município refletirá o quanto sua elite política espera do consenso de seus consumidores-eleitores em relação a sua tomada de decisão de abandonar a estrutura montada para a cooperação.
} 
a consumidores-eleitores de outros, predispondo os outros a retaliar o primeiro, levando a uma escalada por onde as realizações da cooperação seriam eventualmente perdidas.

Portanto, fica evidente que qualquer discussão a respeito dos benefícios de se centralizar regionalmente as decisões de política de saúde pública, envolve também certas externalidades sobre os custos e benefícios de outras políticas.

Além disso, seria uma imprudência observarmos unicamente os Municípios em separado sem considerarmos suas relações com a União, pois, existem movimentos políticos inerciais tanto pela centralização quanto pela descentralização das várias políticas públicas.

Em geral, são movimentos sem qualquer motivação à cooperação, até porque são regrados pela atual Constituição Federal com o fito de se evitar a excessiva centralização ou descentralização de poderes. Essas salvaguardas constitucionais definem deveres e direitos entre os diversos entes federativos e, mesmo sem incentivarem a tomada de decisão pela cooperação, a sua ausência seria fonte de impasse político entre os entes federativos.

\section{9. um modelo de tomada de decisão de se estruturar, ou não, uma cooperação intermunicipal}

Retomando o modelo de Dixit e Londregan (1998), o objetivo desta seção é o estudo da motivação de uma elite política municipal em cooperar, ou não, regionalmente, a partir de sua interação com o grupo de consumidores-eleitores de sua jurisdição.

\section{1. algumas considerações}

Dessa forma, pretendemos obter a decisão coletiva do grupo representada pela individual de seu consumidor-eleitor mediano, o qual, como qualquer indivíduo, procura maximizar a sua utilidade. No entanto, observe-se que os todos consumidores- 
eleitores necessitam de informações, e por essa razão, varia no tempo a limitação da racionalidade de cada um deles, inclusive pelo aprendizado de decisões anteriores, e, portanto, também se altera o indivíduo a ocupar a posição de consumidor-eleitor mediano desse grupo.

Além disso, na medida em que se atenue a assimetria de informação e o comportamento oportunístico das elites, as racionalidades dos consumidores-eleitores tendem também a homogeneizarem-se, reduzindo os custos políticos da negociação entre os partidos e os grupos. O que nos remete, outra vez, à idéia de compromisso político.

Torna-se, portanto, interessante analisarmos a tomada de decisão coletiva a partir das promessas de campanha. Afinal, o partido que melhor "colar" suas promessas às preferências da maioria dos consumidores-eleitores tende a vencer, e, portanto, a elite política a ele atrelada a decidir pró ou contra a cooperação. É por isso que os partidos procuram desenvolver mecanismos de revelação das preferências, a fim de ajustarem suas promessas a elas. Ao final, cada grupo de consumidores-eleitores terá escolhido entre cooperar ou não na prestação regional de serviços de saúde pública.

Após essa escolha coletiva, os componentes do grupo esperarão que a elite política vencedora observe os compromissos assumidos com as respectivas promessas de campanha. Principalmente, quando em comum com as outras elites vencedoras na região buscarem, ou não, a constituição de uma estrutura de cooperação sob pena de desequilíbrios de poder, a partir do confronto de grupos de interesse na região.

Afinal, não é difícil inferir-se que há vínculos entre as motivações das elites políticas a cooperar com as próprias promessas de campanha, e destas com as das demais elites políticas na região.

\section{2. redesenhando o ambiente}

Adaptamos o modelo de Dixit e Londregan (1998), inicialmente voltado à integração européia, de modo a utilizarmos a promessa de distribuição de renda como incentivo ao comportamento de consumidores-eleitores, elites políticas e de partidos 
políticos. Para tanto, definimos duas dimensões da seguinte forma: a ideologia, representada pelos principais partidos políticos em disputa pelo voto dos consumidoreseleitores, e tática ou política, representada pela dinâmica da redistribuição a grupos de indivíduos "mutáveis" ao sabor da renda que lhes for "prometida" redistribuir.

Então, por traz dessa última dimensão, há uma "promessa" de distribuição de renda proporcional à combinação da adesão ideológica desses grupos de indivíduos a um determinado partido, desde que seu apoio influencie na vitória eleitoral. Ou seja, os partidos políticos vão pretender, no processo eleitoral, conquistar o apoio dos diversos grupos regionais a suas respectivas políticas.

Esses grupos são formados por consumidores-eleitores que tem em comum residirem na mesma jurisdição municipal. Cada um dos consumidores-eleitores tem uma posição ideológica, resultado da combinação linear entre dois pólos: estruturar, ou não, a cooperação voltada ao setor de saúde pública na região. Evidentemente, quanto mais próximo se situar do ponto médio das possíveis combinações, ordenadas conforme a preferência revelada de cada um deles, mais fraca será a postura ideológica, e, por conseqüência, quanto mais próximo dos pólos, mais forte a sua postura ideológica do consumidor-eleitor observado.

Para simplificar, consideraremos dois partidos na região disputando os votos dos vários grupos. Eles estarão se "comprometendo" a direcionar gastos futuros conforme sua postura ideológica, nesta ou em outras políticas públicas, pois, admite-se que os partidos conheçam as implicações da complementariedade entre elas, mas, sem conhecerem as preferências políticas dos consumidores-eleitores. Por outro lado, os partidos políticos tratam como críveis qualquer revelação que se expresse por meio de alguma representação dos grupos, principalmente, as que se vinculam aos benefícios redistributivos dos serviços públicos de saúde.

Também consideraremos que cada consumidor-eleitor se preocupa com duas coisas: seu consumo privado e a sua posição social. Quanto ao consumo privado, admitiremos que cada um dos consumidores-eleitores, ao se preocupar com a sua restrição orçamentária, acaba desejoso de poder priorizar a alocação dos gastos em determinadas políticas públicas, na medida em que esta alocação reduza a sua restrição orçamentária futura, ampliando, portanto, a sua expectativa de consumo privado futuro. 
E, quanto à posição social, a vincularemos a uma realidade ${ }^{113}$ ainda não observada por ele: a de dispor ${ }^{114}$, ou não, de acesso a um serviço público de saúde regional, portanto, de cunho ideológico, até porque, os partidos são lentos em mudar a posição social dos consumidores-eleitores.

Por outro lado, os partidos são rápidos em alterar promessas eleitorais táticas de tributar ou transferir renda a diferentes grupos, e, portanto, de promessas de consumo privado futuro e de alocação de gastos públicos, na busca do apoio por meio do voto dos consumidores-eleitores. É evidente que cada grupo possui uma diversidade de preferências de cunho ideológico, expressa pela possibilidade de se atribuir, ou não, a uma estrutura de cooperação intermunicipal de serviços de saúde, a responsabilidade de ofertá-los.

A lógica por trás das promessas de campanha é que cada partido prometa mais consumo privado a um determinado grupo, esperando por uma resposta eleitoral positiva dos consumidores-eleitores. Essa resposta deve vir, principalmente, daqueles consumidores-eleitores que se situam de plenamente indiferentes a qualquer ideologia, àqueles que se encontram à margem da indiferença por qual partido votar, ou seja, aqueles que, de uma certa forma, equilibram suas preferências entre ideologia e consumo.

Porém, se a restrição orçamentária do Município for também conhecida pelos consumidores-eleitores, estes saberão que a promessa política de oferecer mais a determinado grupo implica menos a um outro qualquer grupo. Portanto, os partidos políticos têm que calcular as vantagens relativas de "cortejar" um grupo ao invés do outro.

Admitiremos a existência de um mecanismo que revele as preferências de cada um dos consumidores-eleitores antes do escrutínio. E, a partir do conceito de preferências reveladas, estas seriam ordenadas em função dos respectivos graus

\footnotetext{
${ }^{113}$ A existência ou não de uma coalizão voltada à prestação de serviços públicos de saúde.

114 Diga-se, se a discussão fosse a manutenção ou não de um sistema regional, ainda assim seria ideológica.
} 
individuais de interesse pela adesão a uma dessas duas questões ideológicas: ter ou não os serviços de saúde pública prestados por uma estrutura de cooperação intermunicipal.

Estabelecem-se então, pela regra da maioria simples ${ }^{115}$, as tendências de um determinado grupo por um destes pólos. Observe-se que a tendência ideológica coletiva, sob a regra de maioria simples, tende a ser a mesma de seu consumidor-eleitor mediano $^{116}$.

Também, se estimam as tendências desses consumidores-eleitores às políticas de transferências de renda oferecidas a eles por meio das promessas de realocação de gastos públicos, para o incremento de seus níveis de consumo privado.

Finalmente, define-se por "cutpoint”, ou "divisor de águas", entre dois pólos interligados por uma escala, aquele ponto que posiciona a preferência daquele consumidor-eleitor que se revele totalmente indiferente a adotar uma postura ideológica.

\section{3. resolvendo o modelo}

Inicialmente, algumas suposições deste mecanismo de revelação das preferências coletivas podem ser aventadas. Uma primeira, o número total dos

\footnotetext{
${ }^{115}$ A regra de maioria simples, segundo Ostrom (1986), é uma das regras de agregação. O problema de se aplicar a regra de maioria simples às teorias é a presunção de que um dado resultado obtido se generaliza aos demais casos, esquecendo-se de que existem outros tipos de regras que coexistem com a de decisão. Entre essas regras, temos as delimitadoras, as de autoridade, as de informação, e outras mais. Além disso, não se sabe como os participantes do comitê de decisão foram escolhidos, como podem sair ou serem substituídos; não se sabe como foi elaborada a situação em votação, e, muito menos, os limites que essa política pode ser adotada. Portanto, a tomada de decisão baseada unicamente numa regra de maioria simples pode proporcionar um equilíbrio virtualmente não existente das preferências dos consumidores-eleitores. Por outro lado, quando várias regras são combinadas com a de tomada de decisão por maioria simples, o equilíbrio é muito mais provável de ser alcançado.

${ }^{116}$ Nos modelos de tomada de decisão sobre a provisão de serviços públicos, na vigência de uma regra de maioria simples, se utiliza o conceito de preferência do consumidor-eleitor mediano ao invés da média das preferências dos consumidores-eleitores pelo conceito de maioria simples $(50 \%+1)$ dos votos, e o conceito das preferências reveladas, quando ordenamos os consumidores-eleitores participantes do processo decisório coletivo por ordem crescente de preferências (relativas). Quando tomamos a preferência do consumidor-eleitor na posição mediana, após ordenarmos todos os consumidores-eleitores em razão crescente de suas respectivas preferências, estamos garantindo que todos os consumidoreseleitores situados "antes" do consumidor-eleitor mediano enxergarão a preferência do mediano como mais ampla que às próprias, aceitando-a como suas, portanto.
} 
consumidores-eleitores é irrelevante para o resultado eleitoral de um determinado grupo. Porém, se o número de consumidores-eleitores nesse grupo aumentar mantendo o orçamento municipal limitado, então deve também aumentar os custos aos partidos políticos em prometer alguma transferência de renda aos membros desse grupo.

Uma segunda suposição é a de que os grupos que possuem maior densidade de consumidores-eleitores no entorno do "cutpoint" são os fraca adesão ideológica, e, portanto, favorecidos pelas melhores ofertas de transferência de renda (promessas de campanha política) para ampliação de seus consumos privados. Por outro lado, aqueles grupos de alta densidade fora do "cutpoint" são tomados como de forte adesão ideológica e podem ser desconsiderados da oferta de seu próprio partido, pois, seriam consumidores-eleitores cativos, enquanto que o partido contrário teria um custo muito alto em "seduzi-los" a mudar de posição.

E, uma terceira suposição é a de que os grupos que são mais reativos ao consumo privado se saem melhor, pois tendem a ter uma fraca preferência (ideologia) a qualquer das posições relativas à questão aqui proposta.

A partir dessas suposições, pode-se inferir que grupos de consumidoreseleitores com características "monopsônicas" teriam tendência a uma postura ideológica contra-cooperar, enquanto os grupos "latentes" teriam uma tendência prócooperação.

Também nos é possível inferir que seriam os grupos "latentes" e "monopsônicos" que, com maior probabilidade, devem apresentar maiores concentrações de posições na escala de preferência revelada fora do "cutpoint", mas, diametralmente opostos. Portanto, prevê-se que os custos políticos e o volume das promessas de campanha de consumo futuro para que mudem de posição devam ser muito mais altos em relação aos demais grupos, em especial, os de padrões "privilegiados" ou "intermediários".

Assumindo que os grupos possuem informação assimétrica sobre os dois partidos, muito provavelmente o equilíbrio se daria com cada partido prometendo a uma transferência líquida a cada grupo, em razão do grau de convicção ideológica da maioria do grupo, e do quão esta se cola à ideologia do partido que "corteja" os votos de sua maioria. 
Além disso, não há qualquer restrição a que os volumes totais compromissados por partido possam ser diferentes em razão dos pontos acima considerados.

Porém, de qualquer forma, configura-se um "trade-off" entre ideologia e consumo, onde a possibilidade de um dado consumidor-eleitor se "render ao desejo" pelo consumo privado varia inversamente com a sua convicção ideológica. E, se quiséssemos parametrizar a influência da "força desse desejo" no momento em que esse consumidor-eleitor escolhe entre votar pró ou contra a cooperação intermunicipal, teríamos que relacionar a sua posição numa escala de convicção ideológica, com a do indivíduo que ocupa o "cutpoint" da mesma escala, ou seja, com a posição do consumidor-eleitor indiferente em assumir qualquer das propostas partidárias ${ }^{117}$.

E, então, suponhamos que os consumidores-eleitores pensem numa cooperação intermunicipal estruturada à semelhança de uma federação, com uma certa capacidade de tomada de decisão em relação à política regional. Suponhamos também que cada jurisdição municipal envolvida com essa estrutura de cooperação mantenha o seu "poder de ação" sobre o seu grupo de consumidores-eleitores.

Como conseqüência, teríamos dois níveis jurisdicionais. Ambos teriam capacidade de financiar seus gastos em políticas públicas, "cobrando" seus respectivos demandantes. Os Municípios tributariam ${ }^{118}$ os respectivos consumidores-eleitores, enquanto, a estrutura criada para a cooperação regional "cobraria ${ }^{119 "}$ as quotas-parte dos Municípios conforme contrato de constituição.

Uma hipótese implícita neste modelo é a de que, seja qual for o tipo de estrutura criada para a cooperação, nada impede a ação de partidos políticos distintos, e nem influi na posição majoritária dos grupos de consumidores-eleitores. Além disso,

\footnotetext{
117 Observe-se que não necessariamente o consumidor-eleitor mediano ocupa a posição de “cutpoint".

118 Evidentemente, a suposição neste caso é a de que não se tratam de Municípios "latentes", e se houver algum com essas características, então houve suficiente esforço de coordenação para a aplicação dos necessários incentivos seletivos a todos os envolvidos na integração horizontal.

${ }^{119}$ Note-se que, neste caso, se o critério fosse "per capita" por consumidor-eleitor atendido pela coalizão, esta estaria renunciando à função redistributiva na região.
} 
todos partidos políticos e grupos de consumidores-eleitores podem identificar, por jurisdição municipal, onde estão essas maiorias.

Agora, se agregarmos a estas suposições e hipóteses implícitas, uma outra suposição, a de que os partidos sabem que a soma de todas as dotações dos consumidores-eleitores, além de serem com base em sua renda bruta ${ }^{120}$, também representem o total de recursos da região que é atendida pela estrutura da cooperação $^{121}$, então, o "trade-off" existente entre a posição ideológica e o benefício do consumo privado aumentaria em complexidade, pois, provavelmente, no equilíbrio, cada partido não estaria oferecendo os mesmos benefícios aos diversos grupos da região.

Outro ponto a se considerar nas eleições, é que, qualquer que seja o resultado, ele precede a possibilidade de se realizar qualquer promessa de campanha. Portanto, ao partido contra-cooperação é conveniente que o outro ofereça sua promessa primeiro, uma vez que são as promessas de campanha que influenciam na decisão das maiorias em cada grupo municipal.

Porém, mesmo que o partido pró-cooperação dê o primeiro movimento, nada impede que os consumidores-eleitores formem a expectativa desejada pelo partido em razão do "aprendizado" sobre as realizações de promessas de campanhas anteriores. Além do mais, à medida que a política de saúde pública exercida pela estrutura criada para a cooperação for adquirindo uma "inércia própria", maior será a convicção ideológica dos consumidores-eleitores nas suas escolhas sobre políticas de saúde, se contra ou pró-cooperação.

Afinal, conhecida a distribuição das dotações entre os grupos, e, portanto, como elas variam entre os grupos, as promessas de consumo futuro também se diferenciariam entre os grupos, ainda que estes grupos detivessem o mesmo grau de convicção ideológica.

\footnotetext{
${ }^{120}$ Antes da imposição de qualquer tributo, e também, antes que qualquer transferência lhes seja destinada.

${ }^{121}$ Ou seja, seria uma variável exógena.
} 
É por isso que, na hipótese de as políticas de saúde pública municipais se interagirem numa estrutura regional, também deveríamos considerar que o grau dessa interação intermunicipal poderia variar em função da motivação dos vários grupos de consumidores-eleitores, podendo ser de "monopsônica" a "latente". Portanto, é conveniente ao se definirem as preferências dos consumidores-eleitores de um dado Município, considerar como eles percebem essa interação e a expressam através de seus votos.

\section{4. definindo a escolha coletiva das elites: pró ou contra a cooperação}

Apuradas as eleições municipais, e, portanto, após os dois partidos polarizarem a questão da cooperação em termos de pró "versus" contra estruturá-la, estamos prontos para definir o grau dessa polarização nos diversos grupos municipais. Essa avaliação se baseará na posição dos respectivos consumidores-eleitores ${ }^{122}$ medianos, definida como uma combinação linear dos pólos, em aceitar, ou não, a cooperação intermunicipal de serviços públicos de saúde, e assim, determinar a tendência das respectivas elites políticas em estruturar, ou mesmo prosseguir, com a cooperação a nível regional.

Um ponto importante a se observar é que a polaridade entre gastos e receitas em cada Município deve se ajustar à posição ideológica dos diversos grupos de consumidores-eleitores assumida na última eleição, no que se referente à questão posta de uma estrutura de cooperação existir ou não. Afinal, além da possibilidade de os dois partidos vencerem eleições em Municípios distintos, também se prevêem assimetrias

\footnotetext{
122 Observe-se que, quando nos referimos ao consumidor-eleitor mediano, o relacionamos a um determinado momento da campanha, podendo este ser o resultado do próprio escrutínio. Ou seja, as promessas de campanha de um ou outro partido, realizadas objetivando se colarem à sua função utilidade do consumidor-eleitor mediano, caso fosse possível identificá-la, em nada garante a vitória. Por outro lado, em termos de probabilidade, seria o formato de promessa mais eficiente, na medida em que atingiria as expectativas presumidas à maioria, alterando-a no seu alvo de menor custo: a dos consumidores-eleitores de fraca ideologia. Além disso, nada garante que a posição relativa dos consumidores-eleitores em relação ao mediano se mantenha após a promessa de campanha ser do conhecimento de todos. Afinal de contas, não podemos nos esquecer que cada um dos consumidoreseleitores possui sua própria função utilidade, e, que não podemos nos abstrair das assimetrias de informações entre eles, que faz com que o impacto da promessa seja diferente entre cada um deles.
} 
entre as propensões das elites políticas vencedoras a implantar a sua ideologia no respectivo Município, em razão do tamanho da respectiva maioria vencedora de consumidores-eleitores e de seu grau de convicção ideológica.

Como conseqüência, quando as elites políticas avaliarem qual posição assumir entre si, a partir do resultado obtido dessas eleições, o farão de diversos comprometimentos políticos com suas "bases". Inclusive, o fato de as elites políticas não se aterem aos compromissos políticos com as promessas de realocação de gastos públicos justificaria, tanto ao partido pró-cooperação, quanto ao contra, a manutenção do "status quo".

No entanto, na necessária acomodação política regional que se seguiria ao resultado do escrutínio, as elites políticas vencedoras se manifestariam em função de suas respectivas ideologias, se pró ou contra a cooperação. No entanto, qual dos representantes das duas ideologias agiria primeiro?

Se uma das elites partidárias da contra-cooperação fizer o primeiro movimento, as partidárias da pró-cooperação, principalmente a dos grupos tendentes a "latente", poderão reagir dizendo-se motivadas pelo combate à discriminação de grupos, pretendendo a equalização e assumindo que as receitas municipais para a implementação da política pública de saúde surgirão em razão da própria cooperação $^{123}$.

No entanto, se as elites contra-cooperação forem maioria, provavelmente poderão interferir na estrutura da cooperação, e, portanto, anular os seus feitos até então. Embora, nada indica, numa situação em que a estrutura de cooperação já existisse, que a restrição orçamentária dessa estrutura se alteraria com alguma elite partidária da contra-cooperação movendo-se primeiro. Inclusive, as partidárias do prócooperação sempre poderiam se "aproveitar" das ações contrárias, atribuindo às elites contra-cooperação os ônus políticos decorrentes da redução na qualidade ou quantidade do serviço ofertado pela estrutura de cooperação.

Agora, admitamos que na arena política, alguma elite partidária do prócooperação tome a iniciativa pela sua implantação ou manutenção, e, novamente,

\footnotetext{
${ }^{123}$ Observe-se que, implicitamente, se presume a atribuição da função distributiva de renda na região à coalizão.
} 
admitindo que o faria na medida em que o grupo de elites políticas pró-cooperação na região fosse a maioria. Neste caso, juntamente com as demais partidárias, poderiam arregimentar todos os recursos disponíveis na estrutura da cooperação, redistribuindoos com base nos compromissos anteriormente assumidos os grupos municipais envolvidos na sua estruturação, podendo, inclusive, afetar a distribuição de renda dentro das jurisdições municipais com maiorias contrárias.

O interessante é que, nessa barganha, provavelmente nenhuma elite política partidária da contra-cooperação teria qualquer vantagem a conquistar com um segundo movimento. Afinal, numa barganha que envolve aspectos redistributivos na região, a ameaça de sair é reduzida na medida em que a elite contra-cooperação considere numa relação custo benefício, que o ônus político de sair seja maior do que o de cooperar.

Ou seja, cada elite política deve considerar em sua matriz decisão, a propensão ideológica de sua respectiva maioria, pois, uma parte do total de suas receitas tributárias, incluindo as transferências verticais recebidas, que já estão, ou seriam comprometidas com a estrutura da cooperação, será novamente redistribuída entre os diversos grupos municipais envolvidos, inclusive o seu.

De qualquer forma, ressalte-se que sempre haveria uma assimetria entre os recursos comprometidos com a cooperação e o que cada um dos Municípios desejaria disponibilizar de recursos financeiros ao setor de saúde pública, independente de qualquer maioria ideológico-partidária que se observe entre as elites políticas da região.

Observe-se que a este modelo, poderíamos acrescentar algumas outras peculiaridades. Uma delas é a ação de uma instituição supra-municipal responsável pela coordenação da integração horizontal de saúde pública. No caso, a União poderia induzir ao resultado pró-cooperação na medida em que, no desempenho de sua função distributiva, utilizasse com eficiência a normatização das transferências verticais, como um incentivo seletivo à cooperação na região. Diga-se, a eficiência redistributiva da União seria inversamente proporcional, em razão das assimetrias informacionais, quanto melhor pudesse identificar previamente entre os Municípios de uma dada região, aqueles de "monopsônicos" a "latentes" no âmbito da política pública de saúde. 
Agora, admitimos que existe uma estrutura de cooperação intermunicipal voltada à saúde pública, de tal forma que a ideologia da eleição se polariza entre duas quaisquer políticas redistributivas regionais a partir da estrutura da cooperação.

Desta feita, provavelmente, os partidos políticos estariam preocupados em também influenciar na tomada de decisão de redistribuição de renda, que poderia estar centralizada na estrutura de governança dessa política pública "cooperada". A razão disso é óbvia: desejam influir na escolha eleitoral dos consumidores-eleitores municipais. Ou seja, os partidos buscariam uma resposta favorável às suas promessas de campanha, inclusive, com aquelas que, neste caso, também se correlacionariam com a distribuição de renda.

Portanto, a nossa presunção é a de que a definição dos partidos vencedores nos diversos Municípios também dependeria do que acontece na estrutura da cooperação. Tanto é que, mesmo que insignificante ao resultado, se o voto de um consumidor-eleitor em uma eleição municipal, como todos os demais, for uma consequiência de sua postura social e de suas experiências adquiridas, se dirigido ao partido que maximiza a sua utilidade individual, e se o consumidor-eleitor é capaz de perceber a qualidade dos serviços prestados cooperativamente; então, podemos atribuir ao desempenho de sua estrutura de governança um papel de prognóstico do resultado das eleições municipais.

Note-se que, neste caso em que o julgamento eleitoral é pela adoção de uma determinada política redistributiva, terão muito mais influência os resultados percebidos da cooperação, e, portanto, dos incentivos seletivos aplicados na região, do que propriamente as promessas de campanha de consumo futuro. O que queremos dizer é que as posições ideológicas estarão muito mais definidas, e, portanto, os custos em sua mudança tenderão a serem muito mais altos aos partidos.

Com isso, a renda que efetivamente seria transferida a um dado grupo não dependeria de qual partido vença nos Municípios e nem de qual conseguiria vincular a sua imagem às políticas redistributivas da estrutura de governança da cooperação, pois, muito provavelmente, ambos os partidos teriam idênticas promessas de políticas redistributivas no setor de saúde. 
Porém, embora as promessas de campanha dos partidos possam ser idênticas, se considerarmos que o tipo de Municípios pode variar de "monopsônicos" a "latentes", então poderíamos prever múltiplos equilíbrios na região abrangida pela estrutura da cooperação, pois, dada a diversidade de tipos de Municípios, múltiplas também seriam as posturas ideológicas, quando se envolvessem os aspectos redistributivos da política pública objeto da estrutura de cooperação.

Além disso, o equilíbrio obtido em cada Município resulta num "cutoff” em cada uma das eleições municipais. Assim sendo, pode-se prever a multiplicidade desse equilíbrio a partir da variação da identidade do consumidor-eleitor a ocupar o "cutoff”; da variação na composição da maioria vencedora das eleições municipais; e, por fim, da composição agregada das funções utilidade de cada um dos consumidores-eleitores que participam dessa maioria.

\section{0. as interações entre as elites políticas e a burocracia da cooperação}

No capítulo anterior, vimos que as políticas públicas em geral, em um sistema federativo, têm conseqüências redistributivas. Embora, a nível regional, esta função possa se operar pela interação entre os Municípios com a respectiva estrutura de cooperação, evidencia-se que a burocracia da cooperação deveria considerar que as elites políticas municipais procurariam se aproveitar dos ganhos políticos após a redistribuição. No entanto, esta conclusão não reduz a necessidade de se vigiar como as regras do jogo são dadas; mesmo porque, devem-se considerar nesse jogo pela cooperação, os custos políticos que incorrem os participantes.

Segundo Ostrom (1986), aplicando-se o clássico modelo de arena de eleição de Downs, pode-se concluir que o processo eleitoral baseado numa regra democrática pode coagir um partido político a selecionar a combinação dos custos de produção mais próxima da preferência do consumidor-eleitor mediano de um determinado grupo jurisdicional. Assim, cada partido buscaria a vitória, a partir de sinalizações de eficiência alocativa e redistributiva que mais se aproxime das preferências desse consumidor-eleitor mediano. Portanto, sob a ameaça de não ser reeleita, e temendo a 
performance eleitoral do partido oponente, a elite política na situação tentaria também garantir sua futura re-eleição com essa mesma seleção, a partir de suas observações acerca das preferências dos consumidores-eleitores de sua jurisdição.

E, em meio a essa situação, retomamos a análise de como a burocracia da cooperação pode afetar o vínculo entre as preferências dos consumidores-eleitores e a performance eleitoral da elite política da situação. Um possível enfoque pode estar no processo de barganha entre as elites políticas envolvidas com a cooperação, e a burocracia da cooperação, responsável direta pela quantidade e qualidade dos serviços públicos de saúde. Obviamente, um comportamento esperado e racional da burocracia é a obtenção de recursos tão amplos quanto possíveis, até mesmo para que possam auferir privativamente alguns bônus políticos, além de proporcionar a produção do beneficio esperado pela região com os serviços de saúde pública.

Se as elites políticas conhecem as preferências da maioria dos consumidoreseleitores que as elegeram, poderíamos admitir que elas deteriam um maior poder de barganha na escolha da burocracia. No entanto, em geral, as elites políticas não conhecem os custos de produção do serviço de saúde pública, e, portanto, a escolha da burocracia detém outras motivações que não simplesmente a vontade política das elites municipais.

Com isso, a tendência é que as preferências desejadas dos consumidoreseleitores são precedidas pelo que a burocracia toma como nível ótimo de produção desses serviços públicos. O benefício resultante pode até ser ótimo tecnicamente, mas, politicamente, pode não ser o desejado pela maioria dos consumidores-eleitores, o que "per si”, significaria conflito entre a burocracia da cooperação e as elites políticas envolvidas, que na arena das barganhas seria resolvido em favor daquela que detivesse maior credibilidade em suas ameaças, uma de sair ou não produzir, e a outra de expulsar e assumir a condução da cooperação. Nessa barganha, ambas estariam sujeitas aos ônus e bônus políticos do novo equilíbrio ajustado entre elas.

Um outro argumento, talvez mais realista, poderia ser enfocado pelo lado dos gastos à estrutura da cooperação. Ou seja, na barganha entre a burocracia da estrutura de cooperação e as elites políticas envolvidas, uma ameaça crível poderia ser a manutenção do nível orçamentário dirigido à estrutura da cooperação e, portanto, 
negando qualquer pedido de ampliação feito pela burocracia. Devemos não nos esquecer de que a reação da elite política à proposta de incremento orçamentário à cooperação pode não ser tão confiável, na medida em que elas desconheçam a função produção dos serviços de saúde pública.

Por isso mesmo, negar o incremento orçamentário costuma ser uma posição fraca das elites políticas, o que leva à possibilidade de que o equilíbrio encontrado na arena de barganhas implique num orçamento, cuja produção de serviços apresente uma sobre oferta não ótima.

Observe-se que as situações desenhadas entre as elites políticas e a burocracia da cooperação são meramente operacionais, pouco ou nada envolveram as regras e "circunstâncias" que as produziram. Quanto a considerar as "circunstancias" que influenciariam o equilíbrio a ser obtido numa barganha e, as entendendo como sendo especificações de serviços e do público alvo, ou, considerações acerca dos serviços de saúde pública poderem ser definidos como divisíveis na produção, embora sujeitos a um conhecimento tecnológico específico, inferimos que, necessariamente, essas “circunstâncias" não são responsáveis pelos resultados previstos na barganha.

A razão estaria nos diferentes enfoques aplicados sobre as regras, que podem com maior facilidade, do que as "circunstâncias", afetar as situações observadas entre os personagens, e, portanto, os resultados de uma barganha entre eles. Afinal, a burocracia detém a capacidade de fazer uma ameaça do tipo "tome-o ou largue-o" ("take it or leave it"), na medida em que detiver o controle sobre a produção dos serviços públicos de saúde.

Portanto, considerando que a arena de barganha é composta de dois personagens, as elites políticas e a burocracia, presume-se uma regra de unanimidade para a tomada de decisão que, em geral, pode assumir a escolha de duas condições, o que os levaria a prever, na possibilidade de uma falha de tomada de decisão, a aplicação de uma regra de agregação entre os envolvidos, “ex-post” à barganha. Essa regra de agregação poderia ser formatada da seguinte forma: se não estabelecido um novo ponto de equilíbrio, podendo até ser o mesmo, com a unanimidade na barganha, então, se mantém o "status quo" da cooperação intermunicipal. 
O interessante é que estamos num ponto deste capitulo preocupados com as interações entre as elites políticas e a burocracia da cooperação, percebendo mais uma vez, que os custos e benefícios de uma cooperação intermunicipal podem, ou não, serem afetados pela centralização da tomada de decisão sobre a política pública regional de saúde, na respectiva estrutura de governança dessa cooperação regional.

No entanto, essa variação orçamentária da cooperação poderia surgir de eventuais restrições voltadas a impor a alguma elite política envolvida, uma disciplina às normas da União, com a respectiva minoração das transferências financeiras, e, portanto, reduzindo as remessas dessa elite política à estrutura da cooperação, deprimindo seus objetivos, e ampliando os conflitos das elites políticas com a sua burocracia.

Não nos esqueçamos de que, por trás do conceito de remessas financeiras à estrutura da cooperação estaria o necessário esforço coercitivo da União em coordenar com eficiência o financiamento dessa estrutura. Este esforço também poderia ser atribuído à sua burocracia, na medida em que o seu objetivo seja a otimização dos serviços públicos de saúde na região.

Além disso, se todas as elites políticas municipais puderem equilibrar seus orçamentos, então, podemos também admitir a minoração dos riscos desta cooperação intermunicipal, e, disponibilizar à sua burocracia os instrumentos necessários para a condução da política pública de saúde na região.

Assim sendo, e embora reconheçamos ser de pouquíssima probabilidade, admitamos a título de um exercício intelectual, que a burocracia da estrutura da cooperação pudesse impor um orçamento proporcionalmente maior do que aquele que resultaria como agregado dos orçamentos previstos individualmente pelos Municípios ao setor de saúde pública. E, que isso fosse possível a partir de regras que impusessem às elites municipais o equilíbrio orçamentário.

Além disso, admitamos também que essas regras contivessem os necessários poderes de coerção, de modo que a cooperação, enquanto estruturada pelos Municípios, pudesse agir como um ente regulamentador regional.

Se isso fosse possível, então a centralização da política de saúde pública na sua burocracia poderia amplificar a otimização desses serviços na região com a 
centralização fiscal e a integração política do setor de saúde, com todos os Municípios comprometendo-se diante dessa burocracia com parcelas de sua receita tributária.

No entanto, se houver a centralização da tomada de decisão na burocracia da cooperação, um dos comportamentos racionalmente esperados dela seria o de reduzir a credibilidade de uma ameaça de sair de qualquer Município envolvido. Uma forma de se obter isso, seria por meio do enfraquecimento do poder de veto daquelas elites políticas que se opõem à sua política redistributiva regional no setor de saúde.

Talvez este seja a principal razão, pela qual a tomada de decisão das elites políticas de estruturar uma cooperação envolva limites à transferência de poder político a sua burocracia. Além de refletir um ponto de equilíbrio ${ }^{124}$ entre as influências de grupos de consumidores-eleitores prós e contra a cooperação; também, ressalvadas as devidas proporções, também refletiria o equilíbrio alcançado por um movimento federativo de formação de um ente que surja da vontade das partes em constituir um todo, transferindo-se a este ente poderes sobre todos os constituintes, embora, preservando formas de controle num processo denominado de "pesos e contrapesos".

\section{1. os gastos na cooperação sob o enfoque da escolha pública}

Até aqui ${ }^{125}$ consideramos que cada elite política buscava agir no melhor dos interesses de seu grupo de consumidores-eleitores. E, assim sendo, as políticas fiscais de cada Município, no que concerne àquela voltada à saúde pública, estaria comprometida com a estrutura básica da cooperação intermunicipal, tal que o financiamento de sua atividade seria alterado somente se houvesse um consenso significativo entre as elites políticas.

\footnotetext{
${ }^{124}$ Inclusive a busca desse equilíbrio também justifica a redução da possibilidade de renegociação entre os Municípios envolvidos.

${ }^{125}$ No capítulo anterior, assumimos que não havia diferenças distintas entre os consumidores-eleitores, até por que, como já observado, a teoria tradicional de finanças públicas se desenvolveu a partir da teoria do consumidor, na qual a tomada de decisão é individual. Ou seja, a teoria tradicional não consegue prever conflitos de preferências, e muito menos, escolher entre elas, a de maior peso. A única ineficiência em potencial prevista pela teoria tradicional advinha da competição tributária.
} 
Isso evidentemente ajudava a burocracia da cooperação a reduzir os efeitos em potencial das pressões por mudanças na forma de financiamento, e, portanto, dos custos políticos que surgem de grupos de interesse motivados pela criação de possíveis benefícios, como contra partida pelo tributo que entregam.

Por outro lado, sob a ótica dos grupos de pressão contrários a qualquer aumento tributário dificilmente se estruturaria uma cooperação, pois, quaisquer modificações nas alíquotas tributárias teriam custos políticos, inclusive daqueles que pressionam por solução ao sub-provisionamento de serviços de saúde pública. Portanto, há que se reconhecer que as motivações atinentes aos gastos públicos têm implicações na estabilidade da cooperação.

Portanto, ainda com base na teoria da escolha pública, a qual relaxa a hipótese da teoria tradicional quanto à homogeneidade das preferências dos consumidores-eleitores de um mesmo grupo, que nós redirecionaremos nosso foco para além do processo político polarizado e da noção de custos políticos, de tal modo que passemos a observar especificamente os gastos ${ }^{126}$ públicos.

E, em assim fazendo, retomamos a preocupação de como revelar ${ }^{127}$ as preferências dos consumidores-eleitores por serviços públicos de saúde sob este enfoque redirecionado. Afinal, embora o processo político ajude a revelar preferências, a regra de maioria conduz a não otimização da oferta de serviços, pois, sempre há quem revele preferências positivas por benefícios pagos pelos outros. Como exemplo, lembramos do grupo de consumidores-eleitores tipo "latente". Por outro lado, há quem se manifeste contra em pagar pelos benefícios recebidos por outros, tal como os consumidores-eleitores de um grupo "monopsônico" ou mesmo "privilegiado".

Evidentemente, sob esse aspecto, um equilíbrio poderia ser obtido se o "preço tributário" incidisse sobre quem demanda o serviço, e assim, todos os consumidoreseleitores concordariam com a quantidade do serviço a ser ofertado, e as elites políticas

\footnotetext{
${ }^{126}$ A teoria tradicional define o nível ótimo de gastos públicos como a soma das demandas de todos os consumidores-eleitores.

127 Até por que, segundo Wicksell (1896), é desejável se vincular uma dada ação tributária com o benefício ao consumidor-eleitor, como se houvesse um "preço" previamente previsto por um "acordo" entre consumidores-eleitores e as elites políticas, antes que ambos se incumbissem pelos respectivos gastos públicos.
} 
poderiam tomar decisões menos custosas. Dessa forma, faria sentido um "tributo per capita" que financiasse o serviço público de saúde, na medida em que seu valor se aproximasse do benefício ofertado, facilitando um acordo político pelo nível ótimo de oferta desse serviço.

No entanto, a política tributária se caracteriza pelas acomodações políticas, principalmente, aquelas que distribuem a receita tributária a determinados gastos públicos. Por isso, ao lado da polarização que vimos em seção anterior, sobre se estruturar ou não uma cooperação, também temos a "luta" entre aqueles que esperam ser beneficiários líquidos com aqueles outros que não querem ser os perdedores líquidos, pois pagam tributos, dos quais, uma parte é destinada a financiar serviços públicos de saúde.

A realidade nos mostra que ganha o sub-grupo com maior poder político. E, para a consecução desse resultado, as partes envolvidas não incorrem somente em custos políticos. Afinal, é provável que o processo de tomada de decisão das elites políticas se conduza na direção de uma provisão ineficiente desse serviço público.

Por isso, também preocupados em minimizar os custos políticos, nos parece oportuno investigar as regras ${ }^{128} \mathrm{com}$ as quais os grupos de pressão podem se expressar politicamente sobre o financiamento de uma cooperação intermunicipal de saúde pública. E, para isso, passamos também a buscar recursos na teoria dos contratos.

Assim sendo, poderíamos deduzir a reestruturação de gastos fiscais de cada Município a partir de algumas regras relativamente inalteráveis e previamente estabelecidas no contrato de estruturação de uma cooperação, que comprometem parte das receitas fiscais dos Municípios com os serviços por ela ofertados regionalmente. Em compensação, se reserva uma flexibilidade na fase pós-estruturação para ajustes na política pública de baixos custos políticos.

Por exemplo, o contrato que estrutura cooperação intermunicipal voltado à prestação regional de saúde pública poderia, por meio de uma regra contratual, definir que todos os Municípios componentes devam prover sua cota parte de financiamento

\footnotetext{
${ }^{128}$ Buchanan e Tullock (1962) argumentam que os “(...) custos políticos são inversamente relacionados à facilidade com que as regras podem ser modificadas” .
} 
em razão de determinado critério de rateio, flexibilizando que os eventuais ajustes no cálculo desse valor seriam acordados "pós estruturação".

O problema então, estaria no grau de flexibilização "pós-estrutural” acordado, pois, ele seria um sinalizador às elites políticas de quanto custo político incorreriam, se tentassem modificações em seu benefício.

Portanto, configura-se uma linha tênue entre as provisões financeiras formais à cooperação intermunicipal, enquanto prevista no contrato, com as decisões acordadas “ex-post”, mesmo que as regras para a sua tomada de decisão estejam formalmente previstas no contrato.

No entanto, ainda há uma variável a se considerar: o compromisso das elites políticas em manter o sistema tributário. Afinal, já observamos que qualquer sistema de alíquotas tributário pode induzir consumidores-eleitores proprietários dos fatores de produção de bens e serviços em geral, a localizá-los em suas jurisdições, e, portanto, a manter a base tributária e os gastos na prestação dos serviços de saúde pública. O detalhe é que especificamente este compromisso tem características de uma regra informal, não contida num contrato público.

Na prática, a questão do compromisso surge com os consumidores-eleitores, e, portanto, os fatores de produção, reduzindo o grau de mobilidade com a tomada da decisão de qual Município residir, pois, as variações na política tributária influem na mobilidade dos fatores. Inclusive, alguns dos consumidores-eleitores podem escolher deixar o Município se a alíquota tributária for ampliada, induzidos pela busca de outras menores.

Agora, o mais interessante, pelo seu paradoxo, é que a competição tributária, um comportamento não cooperativo, pode ajudar a resolver esse problema de compromisso. Para demonstrar isso, tomemos o exemplo de um investidor que estuda o local para a instalação de um hospital "referência regional", devendo se decidir entre dois Municípios de uma dada região. A sua decisão quanto ao local de investimento baseia-se no Município que apresentar maior "capacidade" de atrair demanda na região.

As respectivas elites políticas escolhem as alíquotas que incidirão sobre a produção projetada desse serviço em suas jurisdições, induzindo a direção do hospital a escolher tanto o local, quanto o nível de produção do serviço. Nesse caso, o 
compromisso já surge com as elites escolhendo as alíquotas tributárias antes de o hospital fixar seu nível de capacidade. Se existisse uma cooperação já estruturada, então, provavelmente, teríamos a mesma alíquota em toda a região, e o hospital, conhecendo este incentivo somente no momento da decisão, poderia até não investir.

No entanto, como temos duas elites políticas competindo pelo hospital com suas alíquotas tributárias, o incentivo percebido tende a se amplificar, podendo então o hospital escolher um dos Municípios para se instalar. Agora, se as elites propuserem subsídios aos custos de investimento, o hospital poderá se instalar com excesso de capacidade, ou então, procurará redirecionar sua produção de serviço entre os Municípios em razão das diferenças de suas alíquotas tributárias, até como um contra incentivo para se ampliar a competição tributária, e uma maior redução nas alíquotas.

Por outro lado, é possível que altos custos políticos previnam as elites políticas a não participar de um processo de troca política como no exemplo acima, principalmente, se os custos impostos pela barganha, junto aos respectivos grupos de consumidores-eleitores, excedam os benefícios esperados. Da mesma forma, se os benefícios líquidos de uma cooperação intermunicipal estiverem ocorrendo apenas a um dado grupo, tal como os grupos "latentes", e, se os custos políticos recaíssem sobre elites políticas que somente pretendam preservar o "status quo", então, provavelmente, a mesma conclusão é reforçada: dificilmente continua a cooperação.

Por outro lado, pode-se esperar que mudanças institucionais, ou mesmo a ação coordenadora da União, possam também limitar os custos políticos. Afinal, o sistema de alíquotas tributárias surge de um processo de tomada de decisão política, daí nosso interesse pelo estudo sobre o processo pelo qual a estrutura de uma cooperação seria projetada.

\section{2. da competição tributária à cooperação, pela redução do gasto público}

A competição tributária também tem benefícios, e, já vimos que não há por que lhe negar isso. Tanto é verdade, que Wilson (1999) argumenta que ela “(...) melhora o bem-estar, pois o tamanho do governo seria excessivo na ausência de 
competição". No capítulo anterior, vimos a teoria tradicional de finanças públicas focando nas implicações de bem-estar da competição tributária a partir de uma estrutura federativa centralizada, onde a União não se preocupava com a ampliação do tamanho do setor público.

Enquanto isso, neste capítulo, assumimos também que qualquer elite política é "benevolente" sobre a coisa pública. Por outro, também a observamos preocupada em manter-se no poder, e o quanto isso poderia impactar em suas motivações à cooperação.

De qualquer forma, podemos intuir que Municípios de uma mesma região, competindo entre si, tendem a reduzir o tamanho ${ }^{129}$ total dos governos na região em razão tanto da otimização dos recursos disponíveis, quanto da sub provisão dos serviços públicos. O interessante nesta presunção, é que provavelmente ela também se correlaciona com o aumento do número de Municípios envolvidos na competição.

Confrontar um estado único, eminentemente centralizador, com a solução de uma cooperação regional, através da qual as elites políticas tomam decisões sobre a política pública de saúde na região, nos leva a perceber, entre a política pública de um estado único, e a de vários Municípios organizados voltados à cooperação intermunicipal, algumas formas diferentes de controle dos mesmos instrumentos ${ }^{130}$ de política.

Ou seja, a eficácia desses instrumentos também dependeria de quem exerce o controle sobre eles. Poderiam ser os consumidores-eleitores ou de seus representantes em Conselhos ou algo similar. Por outro lado, alguns controles poderiam não ter a eficácia desejada por vários motivos. Um desses motivos surge de a quem delegar a tomada de decisão sobre a condução da política pública na região, em razão da estrutura de cooperação adotada.

\footnotetext{
${ }^{129}$ Inclusive, Wilson (1999) se referiu aos testes empíricos do modelo em que a centralização é do tipo Leviatã, conduzidos por Oates e outros, como tendo dificuldades em “(...) confirmar a existência de uma relação entre tamanho do governo agregado e a descentralização de decisões fiscais em meio a governos independentes" .

${ }^{130}$ Basicamente se referem às políticas de alíquotas tributárias e de gastos públicos, e, às transferências horizontais e verticais, sendo que sobre estas últimas, as transferências verticais, as elites políticas municipais exerceriam um controle indireto na medida do quão dispostas estriam em se comprometerem com as normatizações da União.
} 
A delegação de competência para tomada de decisão pode produzir ineficiências que se agravariam se a "voz" exercida pelos consumidores-eleitores for também ineficaz. Afinal, essas ineficiências vão depender daqueles que escolhem as políticas de gastos públicos, na medida em que estas escolhas são por critérios reservados, com pouca transparência aos controles dos consumidores-eleitores ou de seus representantes.

Por outro lado, se observássemos somente o lado das receitas, veríamos que a escolha das políticas de alíquotas tributárias é justificada, em geral, por critérios de maximização do bem-estar. Ou seja, os tomadores ${ }^{131}$ de decisão tratam assimetricamente as políticas fiscais quando polarizadas em gastos ou receitas. Em geral, o poder legislativo tem controle direto sobre as alíquotas tributárias, pois as aprova, ou não, em leis específicas, mas, pouca eficiência tem sobre os gastos públicos vinculados às decisões das elites políticas.

É por isso que a estrutura organizacional voltada à cooperação deve prever a delegação do controle de seus gastos no setor de saúde pública a alguma instituição supra-municipal, na qual os consumidores-eleitores tenham voz ${ }^{132}$ para o exercício do monitoramento.

Até porque, sabendo que o controle sobre os gastos é custoso, a estrutura organizacional voltada à cooperação pode se beneficiar "politicamente" controlando a

\footnotetext{
${ }^{131}$ As elites políticas municipais e a burocracia da coalizão.

${ }^{132}$ Para melhor desenharmos esta situação, adaptamos o modelo de Wilson e Gordon (1998) para uma região com vários Municípios, cada um deles com a mesma quantidade de um dado fator de produção de serviço de saúde pública. Neles, todos os consumidores-eleitores têm plena mobilidade. Todos os Municípios aplicam um subsídio "per capita" sobre seus consumidores-eleitores, e uma alíquota tributária uniforme sobre o fator de produção. Com esse desenho, todas as elites políticas entram em competição pela ampliação de sua capacidade de gasto para ampliar a própria provisão do serviço público, atraindo mais consumidores-eleitores proprietários dos fatores de produção e, assim, expandindo a base tributária. Como cada consumidor-eleitor possui uma parcela do fator de produção, este terá a mobilidade dele. Se a mobilidade dos consumidores-eleitores for baixa, então há poucas oportunidades deles serem críveis em suas ameaças de sair num confronto com a elite política, permitindo a expansão da receita tributaria para a provisão adicional de um serviço publico. Não sendo possível a saída, os consumidores-eleitores exerceriam a sua capacidade de voz. A consequiência mais provável é a de que se arrefeça o poder de decisão da elite política num "confronto direto" com os consumidores-eleitores, até por que, é muito possível que as elites políticas não se reelejam, sendo substituídas numa próxima eleição. Essa probabilidade tem sempre direta correlação com a avaliação que os consumidores-eleitores fazem de seu desempenho na função. Observe-se que a voz seria crível, na medida em que o monitoramento das elites políticas fosse feito pelos representantes dos consumidores-eleitores.
} 
provisão do serviço de saúde publica ao longo dos Municípios da região, entendendo essa ineficiência como um "incentivo permissivo" às ações que ampliem o seu bônus político esperado.

E também, é por isso que numa competição pelo gasto publico, a ampliação da mobilidade dos consumidores-eleitores amplia a "eficiência" com que as elites políticas utilizam as receitas tributárias; pois, reduzem o "desperdício" nos gastos.

A conseqüência é que a competição pelo gasto público amplia o bem-estar em todos os Municípios; quanto então, esses mesmos Municípios tendem a se envolver numa competição tributária pela atração de consumidores-eleitores com a prática de alíquotas mais baixas, na medida em que assumam uma correlação positiva com o grau de mobilidade dos consumidores-eleitores.

Porém, cada Município pode estar errando ao projetar, em função da mobilidade dos consumidores-eleitores, um sistema tributário com alíquotas menores, pois, ao contrário do senso comum, as alíquotas mais altas também fortalecem a correlação entre o nível de receita e a provisão ${ }^{133}$ de serviços públicos, ampliando os incentivos às elites políticas em incrementar a oferta deles.

Ou seja, se ao invés de competirem pelos consumidores-eleitores através de reduções nas alíquotas, as elites políticas cooperassem ampliando suas alíquotas simultaneamente, então o incentivo para gastos em serviços seria fortalecido sem qualquer ameaça de saída.

Um outro enfoque seria pelo lado da redução do desperdício nos gastos públicos. Ao fazê-lo, quanto maior a mobilidade dos consumidores-eleitores, maior a credibilidade de sua ameaça de saída, e, portanto, menor pode ser o "preço" efetivo do serviço público; reduzindo inclusive a necessidade do exercício da "voz".

Neste caso, o "preço" tende a ser o suficiente menor, a ponto de incentivar os consumidores-eleitores a prover o setor público com mais receita tributária do que seria

\footnotetext{
${ }^{133}$ No capítulo anterior vimos que as receitas tributárias teriam pouca relevância como variável explicativa da cooperação intermunicipal dada as transferências verticais. No entanto, esta conclusão em alguns casos pode ser precipitada quando consideramos os efeitos de complementariedade das outras políticas públicas, para as quais as receitas próprias tenham importância, e, portanto, alterações nas políticas públicas complementares, na política de alíquotas tributárias acaba tendo implicações na política pública de saúde.
} 
possível numa situação em que o grau de mobilidade deles fosse baixo. Deste modo, ampliar a mobilidade pode ampliar ou reduzir o tamanho total do governo, embora, ambiguamente, o bem-estar agregado se amplia, e a cooperação intermunicipal é estimulada.

\section{3. possíveis formatos da estruturação da cooperação intermunicipal}

Haveria pelo menos duas formas de se estruturar a cooperação intermunicipal: convênio ou coalizão.

Por meio de um convênio, os Municípios envolvidos regulamentariam a "exportação" e a remuneração de serviços entre eles em uma dada região, por meio de contratos que regrariam esse processo de trocas. Quanto à formação de uma coalizão, esta se daria por meio de um contrato constitutivo de uma organização supra municipal voltada à prestação de determinado serviço na região, podendo, não somente substituir os diversos sistemas municipais, mas também, incorporá-los.

Além da distinção entre eles ser possível por meio de suas respectivas estruturas formais, também poderiam ser diferenciados pela intensidade de esforço de coordenação necessário para que cada uma delas pudesse ser implementada. De imediato, intuímos que o esforço necessário de coordenação para a consecução de uma cooperação intermunicipal no formato convênio, é proporcionalmente menor em relação ao formato coalizão.

Se isso é verdade, poderia então explicar porque a cooperação no formato coalizão tende a ser obtida muito mais espontaneamente do que o convênio. Ou seja, dado que o convênio pode ser instituído com menor esforço de coordenação, a União tenderia a adotá-la como solução voltada à ampliação da eficiência dos serviços prestados, empenhando-se em induzir os Municípios nessa direção por meio dos instrumentos que dispõem: a regulamentação e as transferências financeiras verticais.

Esta presunção também encontra apoio na hipótese de Brennan/Buchanan (1980), segundo os quais a descentralização tributária, envolvendo gastos e receitas, implica na ampliação do nível de competição, e, portanto, das externalidades, 
resultando na adoção de estruturas cooperativas intermunicipais como uma solução eficiente.

Ou seja, a partir dessa lógica, eles concluem que a existência da competição tributária aumenta a possibilidade de as elites políticas municipais se agruparem ${ }^{134}$ para organizar um acordo de cooperação mútua, a fim de evitarem as ineficiências da competição.

E, assim sendo, como incremento a essa hipótese, trazemos a idéia de que as estruturas de cooperação podem surgir de vários modos, desde as plenamente espontâneas a até aquelas totalmente induzidas. A razão de agregarmos tal suposição é que com ela vinculamos o grau de necessidade coordenação à consecução dessa estrutura; restando-nos atribuir a algum organismo supramunicipal essa atribuição que, em geral, se presume tratar da União.

Afinal, para essa atribuição, seja qual for a estrutura intermunicipal de cooperação, não seria possível se evitar o envolvimento da União com os Municípios, principalmente, se ela puder coagir as elites políticas municipais a adotarem comportamentos cooperativos e regulamentados, a partir de um sistema de transferências financeiras.

Colocando de uma outra ${ }^{135}$ forma: o investimento em uma estrutura de cooperação tem uma correlação direta com as transferências financeiras da União e o incremento nos gastos a incorrer dos Municípios envolvidos.

\footnotetext{
${ }^{134}$ Isso foi previsto por Brennan e Buchanan (1980) quando observaram que a "possibilidade de cartéis entre entes federativos (...) deve ser incluída entre as outras coisas equivalentes” , numa aparente alusão à similaridade de alguns aspectos do pacto federativo, ou mesmo, outras formas estruturais de cooperação, tais como a coalizão ou convênios. E, prosseguem afirmando que, sem "(...) uma estrutura federal constitucionalmente projetada, alguém poderia prever que existiria uma constante pressão pela competição nos níveis mais baixos de governo para garantir reestruturações institucionais que moderassem as pressões competitivas" .

135 A existência de uma estrutura voltada à cooperação intermunicipal não é a única forma de se interpretar uma relação positiva entre as transferências financeiras e o incremento nos gastos dos governos envolvidos. Existem pelo menos duas outras possíveis formas já tratadas no primeiro capítulo. A primeira vem do uso das transferências financeiras para promover a eqüidade entre os Municípios de uma região; enquanto a segunda surge das externalidades de um serviço público, para as quais as transferências financeiras seriam mecanismos sinalizadores da União para induzir as elites políticas a otimizar ("internalizar" a externalidade) a oferta desse serviço público. Observe-se que, nesta segunda situação, o tamanho do governo aumentaria muito mais pelo acréscimo de eficiência e não necessariamente por causa da existência de uma estrutura de cooperação.
} 


\section{1. a coalizão (interação entre personagens coadjuvantes municipais)}

A partir da hipótese de Brennan/Buchanan (1980), podemos esperar pelo menos duas implicações ${ }^{136}$ na constituição de uma estrutura do tipo coalizão. Uma primeira implicação se referia ao tamanho agregado dos governos municipais envolvidos, o qual, "ceteris paribus" em relação às demais políticas públicas, aumentaria com a cooperação intermunicipal.

A outra implicação, adviria do tamanho de cada governo municipal envolvido, o qual, "ceteris paribus” em relação às demais políticas públicas, também aumentará, desde que a regra de saída permita a qualquer um deles deixar a estrutura coalizão, se não obtiver os benefícios esperados, caso contrário, tende a minimizar os gastos na coalizão.

Da constatação de que uma coalizão pode alterar o tamanho dos governos envolvidos, o que implica em mexer na sua estrutura organizacional, podemos definir uma coalizão intermunicipal como a "organização da cooperação ${ }^{137}$ ". Afinal, a estrutura de uma coalizão é dimensionada para otimizar a distribuição dos recursos na região, a fim de sinalizar estabilidade e credibilidade a todos os grupos de consumidores-eleitores. Além disso, a segurança institucional de uma coalizão pode também ser construída com incentivos a partir de alguma instituição supramunicipal, e dirigidos às elites políticas municipais. O cuidado a ser tomado na sinalização com esses incentivos é de que sejam seletivos os padrões de grupo de consumidoreseleitores, que variaria de "monopsônicos" a "latentes", em razão das motivações

\footnotetext{
136 Essas implicações têm fundamento em Wilson (1999), que se utiliza do trabalho empírico de Grossman e West (1994), com dados de uma série de tempo do Canadá (União, Províncias e Municípios) referentes a gastos fiscais, considerando as transferências financeiras do nível de governo mais alto para o mais baixo, provendo evidência de que a existência de uma estrutura de cooperação entre as unidades governamentais amplia o tamanho dos governos envolvidos, e, sugerindo que essa estrutura possa debilitar a disciplina do federalismo fiscal.

137 A cooperação é percebida pelos personagens coadjuvantes dos Municípios envolvidos, e avaliada por eles a partir da qualidade percebida dos serviços prestados pela coalizão, quando comparada aos próprios sistemas autônomos.
} 
percebidas entre as elites políticas à integração horizontal no âmbito do serviço público de saúde,.

Afinal de contas, não podemos deixar de considerar que os possíveis personagens a participar de uma coalizão podem ter comportamentos oportunísticos e motivações díspares, que podem pôr em risco a necessária segurança institucional da coalizão.

Portanto, prevê-se que a estrutura de governança de uma coalizão deva "exante" sinalizar a segurança pretendida por meio de regras que devem ser críveis. Em especial, as de tomada de decisão de sua burocracia devem se limitar e ser restringidas à atividade objeto da coalizão, evitando-se, inclusive, a formação de sub-coalizões. E, quanto às regras que regulamentam a qualidade e o acesso ao serviço prestado, estas devem ser "autocoercitivas".

Algumas regras, já "ex-ante”, devem estabelecer os critérios de uso sob os quais a coalizão seria administrada. E, os critérios de seu financiamento, se possível, serem definidos por uma combinação linear ajustada entre critérios de uso e populacional, a fim de se minimizarem comportamentos oportunísticos. Especificamente, quanto aos comportamentos oportunísticos "ex-post”, os chamados "riscos morais" e "free riders ${ }^{138}$ ", essas regras deveriam prever mecanismos não somente restritivos à sua ocorrência, mas que também viabilizassem o monitoramento dos Municípios envolvidos.

Quanto às regras de exclusão, como já observado, se revestem de características próprias, afinal, não se pune um governo com seu afastamento por completo do acesso aos serviços. Por outro lado, pode-se afastar aquele Município temporariamente enquanto permanecer inadimplente com alguma das cláusulas do contrato constitutivo. Ou seja, é obvio que, em se tratando de Municípios, os limites impostos pelo contrato constitutivo de uma coalizão não podem ser excessivamente

\footnotetext{
${ }^{138} \mathrm{Ou}$ "caronistas". Uma definição de "free riders" começa por equipará-los aos prisioneiros do dilema de prisioneiros da teoria dos jogos. Ou seja, cada personagem pode achar que a falta de informação sobre o comportamento do outro, e os altos custos para se obtê-la e, portanto, fazer acordos consensuais, tornam a melhor escolha racional não contribuir com seu esforço. Ou seja, o "free rider" é aquele personagem que ,mesmo participando da ação coletiva, considera racional não contribuir com seu esforço individual para o objetivo comum.
} 
rígidos, até por que rigidez em excesso ${ }^{139}$ poderia implicar na perda de credibilidade, na medida em que sinalizasse a inaplicabilidade.

O que devemos nos lembrar é que a necessária e recorrente revitalização do vínculo político entre consumidores-eleitores e as suas elites políticas eleitas impõe aos eventuais problemas que possam surgir alguma limitação temporal. Por isso, qualquer afastamento do serviço ofertado por uma coalizão deve ter condicionantes muitos bem delimitadas, prevendo-se a possibilidade entre as cláusulas do contrato constitutivo de um dado Município infrator retornar à coalizão.

Ou seja, o afastamento, embora não deva ser excessivo, deve ser previsto atrelado às regras de punição, sempre possíveis de serem aplicadas, e, principalmente, às regras sobre a reintegração, até para que se reduza a possibilidade renegociação das condições e do compromisso original, ampliando sua confiabilidade e a segurança institucional da coalizão perante seus usuários: os consumidores-eleitores.

Outras regras poderiam ser consideradas no contrato de constituição da coalizão. As regras de posição que especificariam as posições existentes na coalizão e as situações relativas entre elas. As regras de limite que especificaria como os participantes são escolhidos para as posições e quanto tempo permaneceriam nelas. As regras de extensão que especificariam quanto do beneficio das ações da coalizão poderia ser ofertado externamente. As regras de informação que especificam os canais de comunicação entre os envolvidos e a sua linguagem e forma. E as regras de "payoff”, que prescreveriam como o ônus e o bônus do beneficio ofertado seriam distribuídos entre as elites políticas envolvidas com a coalizão.

Definidas quais poderiam ser as regras, analisemos a coalizão sob o enfoque dos possíveis papéis que os Municípios desempenham na região. Vimos que em regiões onde há grupos jurisdicionais de consumidores-eleitores com sua maioria "latente", ou então, naquelas regiões formadas por muitos e pulverizados Municípios, os quais, em geral, tendem em sua maioria serem também compostos por grupos de

\footnotetext{
139 Afinal, a coalizão sob estudo não é fruto de um Tratado do porte de Maastrich, onde a ameaça de saída é muito pouco crível na medida em que os demais envolvidos obrigatoriamente respondem com a ameaça de guerra.
} 
maioria "latente", podemos pressupor a necessidade de um incentivo externo voltado à formação da coalizão.

Esses incentivos devem ser independentes e seletivos, a fim de estimularem nos grupos "não latentes", uma decisão coletiva de aceitar os "latentes" na coligação. A ação coletiva regional voltada às coalizões intermunicipais para a prestação de saúde pública pode, muito provavelmente, necessitar de algum incentivo externo, atrelado à expectativa dos benefícios pretendidos com a coalizão, incentivos esses que deveriam, como já observado, agir sobre todos os grupos, embora de forma seletiva e discriminada.

O incentivo externo deve ser seletivo no sentido de que aqueles Municípios que decidem não fazer parte da coalizão, como é possível a um grupo "monopsônico", ou, que decidem não contribuir com o esforço acordado para a consecução dos objetivos coletivos, possam ser tratados diferentemente daqueles que colaboram. Esses incentivos seletivos podem ser negativos e positivos, coagindo os agentes inadimplentes com alguma punição, ou estimulando aqueles que agem pelo interesse coletivo.

A instituição que, a exemplo da União, assumir o papel de indutora, ou mesmo, de coordenadora de uma integração horizontal regional estruturada como uma coalizão, deve ter em mente que, ao sinalizar com incentivos seletivos a uma região que contenha Municípios "latentes", pode modificar o equilíbrio distributivo e alocativo nessa região. Isso deve ser um estímulo a essa instituição, para que aja no sentido de fazer participar um Município "latente" de uma coalizão, pois deverá estar preparada a agir no interesse coletivo da região, quer seja por coerção ${ }^{140}$ sobre as demais elites políticas municipais em aceitar o "latente", quer seja pelo estímulo" ${ }^{141}$ de participarem dos benefícios esperados de uma coalizão juntamente com o "latente".

\footnotetext{
${ }^{140}$ Define-se coerção, como sendo a possibilidade de um custo maior que o custo de se prover a parte do benefício coletivo que lhe foi alocado.

${ }^{141}$ O estimulo é definido como uma recompensa ao indivíduo que custeia a cota parte dos benefícios que lhe foram alocados.
} 
De qualquer forma, ao se conseguir fazer com que um Município "latente" se mobilize, amplifica-se a eficiência ${ }^{142}$ regional como um todo, na medida em que se mobiliza a sua capacidade para ações de saúde, até então latentes, as quais só poderiam estar se concretizando com os incentivos seletivos propostos.

Contudo, resta-nos ainda sob o enfoque dos incentivos e motivações para a formação de uma coalizão, analisar a forma da estrutura que lhe dê estabilidade e credibilidade. Isso implica, além da análise de seu desenho institucional e de considerações sobre o uso de regras "ex-ante" auto-coercitivas que limitem a discricionalidade da burocracia da coalizão, que se considerem no desenho contratual regras que protejam os direitos de propriedade e que garantam o financiamento da manutenção da coalizão.

Um comportamento esperado das elites políticas na constituição da coalizão é o de se atribuírem a discricionalidade da condução da política pública de saúde na região, e, portanto, da coalizão.

Por outro lado, esta difusão de responsabilidades pelos resultados da coalizão pode sinalizar aos consumidores-eleitores da região que a estrutura de governança da coalizão não dispõe da segurança institucional esperada.

Portanto, como já observamos, o contrato constitutivo deve definir regras de tomada de decisão, e colocar limites e restrições à atividade da coalizão, com a ressalva de que, se prevalecer uma baixa credibilidade de cláusulas, o contrato pode colocar em risco a coalizão com a ameaça de formação de conluios ou sub-coalizões.

Note-se que, embora a formação de uma coalizão apresente fortes características de ter sido espontânea, ainda assim não prescindiu de alguma forma de coordenação e de incentivos externos. E, além disso, mesmo sendo uma cooperação intermunicipal quase espontânea, ela só pode apresentar a segurança institucional desejada pelos personagens coadjuvantes municipais, na medida em que as regras que

\footnotetext{
${ }^{142}$ Ao se falar em eficiência de uma coalizão, será que há algum critério que nos possibilite medi-la? O que imaginamos como reposta, se apoiaria na avaliação da qualidade percebida por um consumidoreleitor-mediano, expressa pelo seu voto numa regra de maioria simples; embora, nada impeça a adoção de outros critérios, tais como o número de acessos ao sistema cooperativo "vis a vis" com o agregado obtido dos sistemas municipais autônomos. De qualquer modo, pouco importa, até por que, o número de variáveis passíveis de parametrização é muito alto.
} 
regulamentam a qualidade e o acesso ao serviço prestado por ela formarem um conjunto "auto-coercitivo".

Ou seja, não se pode prescindir de um contrato constitutivo confiável, exigindo-se nele mecanismos que confiram credibilidade "ex-ante" ao esperado comprometimento das elites políticas, inclusive, com o financiamento da estrutura.

Portanto, a estrutura que organiza a cooperação exige mecanismos de governança que limitem as aventuras (harzards) contratuais de elites políticas municipais, os chamados comportamentos oportunísticos "free riders". É por isso que desenhamos os comprometimentos de cada elite política a partir das relações políticas entre os personagens coadjuvantes municipais, de modo que todas as elites políticas envolvidas fossem signatárias de um único contrato firmado entre eles.

Dessa forma, todas as elites políticas envolvidas na assinatura de um único contrato constitutivo, estariam expressando uma tomada de decisão entre eles sob uma regra de maioria absoluta dos signatários. E, com essa "arquitetura contratual", ou seja, apenas um único contrato entre todos os envolvidos, confere-se à organização os suficientes mecanismos de "coerção", para que a sua estrutura tenha os recursos necessários aos serviços de saúde pública esperados pela maioria dos consumidoreseleitores da região.

Por outro lado, essa estrutura de governança tem um paradoxo: a "criatura", a coalizão, monitorando o comportamento de seus próprios “criadores”, os Municípios. A partir da literatura, é possível tratar esse paradoxo com a identificação dos eventuais "aventureiros contratuais" ou dos prováveis comportamentos oportunísticos nas relações existentes entre os agentes envolvidos. Se essa identificação é "ex-ante" à constituição da coalizão, então se devem prever cláusulas contratuais que inibam esses comportamentos oportunísticos.

No entanto, essa mesma literatura também prevê que qualquer contrato constitutivo deva conter cláusulas que regulamentem a inclusão de novas regras comportamentais na medida em que se percebam comportamentos oportunísticos não previstos na constituição da coalizão. Seriam como as regras que permitem emendas constitucionais, as quais estabelecem, inclusive, quoruns privilegiados de tomada de decisão. Note-se que a proposta é a de inclusão de novas regras, e não a de 
possibilidade de renegociação das existentes, o que reduziria a confiabilidade do contrato.

\section{2. o convênio (interações entre Municípios e União)}

A partir da ótica dos gastos públicos, e, de certa forma, também da competição tributária intermunicipal, haveria ainda um aspecto não abordado. Esse aspecto emerge de um comentário encontrado em Wilson (1999), segundo o qual é possível se identificar uma outra forma de competição pela mesma base de cálculo, à qual ela a denominou por "competição com duplos convênios tributárias" .

A partir dessa leitura, inferimos uma possível forma de financiamento de uma estrutura de cooperação, a partir de umo convênio tributária intermunicipal que possibilitasse tributar ("precificar") na origem dos consumidores-eleitores qualquer demanda por serviços de saúde ofertados pela coalizão, independente de onde eles sejam tomados.

É como se cada Município estivesse comprando serviços produzidos pelos demais, ao mesmo tempo em que procurasse fazer chegar aos consumidores-eleitores a carga deste gasto incorrido.

Colocando de outra forma, seria como se um Município "importador" de serviços procurasse, na condição de origem dos consumidores-eleitores, tributar seus residentes pelos serviços por eles demandados na fonte, em outro Município. Assim sendo, desenha-se uma situação onde os mesmos fatores de produção desses serviços acabam tributados por dois Municípios diferentes, pelo "exportador" diretamente, e, pelo "importador" indiretamente.

E, não necessariamente, seria um tributo "per capita", principalmente se o respectivo orçamento fiscal contemplasse essa possibilidade. Ou seja, bastaria que as eventuais receitas por transferências verticais vinculadas àquela política pública contemplassem um critério de compensação intermunicipal. Note-se que nesta situação, seria imprescindível a interferência de um ente supra municipal, no caso, a União. 
Esse convênio propiciaria ao Município "importador" a provisão de uma receita tributária obtida de seus consumidores-eleitores pelos serviços pagos ao Município "exportador". Além disso, poderia permitir a consumidores-eleitores do Município "exportador” demandarem em sua jurisdição serviços ${ }^{143}$, cujos correspondentes valores seriam deduzidos numa espécie de conciliação ${ }^{144}$ contábil simultânea. Outra hipótese seria o Município "exportador" simplesmente "isentar" os residentes de outros Municípios vizinhos.

No entanto, esse sistema tem implicações sobre o nível de competição tributária na região. Para exemplificar, admitamos dois Municípios, um exportador de serviços de saúde pública enquanto o outro, importador deles. E, consideremos que ambos se disponham a utilizar as alíquotas tributárias para incentivar o influxo de fatores móveis de produção desses serviços.

Se o Município "importador" conseguir prover uma receita tributária entre seus consumidores-eleitores pelo que demandarem de serviços, então o equilíbrio de Nash provavelmente envolveria equilíbrio entre as alíquotas tributárias praticadas, com a redução do fluxo de fatores entre os Municípios.

Ou seja, se imaginarmos que um Município "importador" tem um incentivo a elevar sua alíquota tributária ao nível utilizado pelo Município "exportador", desde que consiga pagar eficazmente o "preço" acordado ao Município "exportador" pelos serviços demandados pelos seus consumidores-eleitores; então, tão logo a importação de serviços cesse ou reduza, o Município “importador" voltaria com sua alíquota tributária abaixo da praticada pelo Município “exportador”, para sinalizar incentivos ao influxo de fatores a sua jurisdição.

Portanto, o resultado esperado é a prática regional de alíquotas tributárias altas no equilíbrio, a ponto de refrear a mobilidade dos fatores relacionados com a política pública objeto do convênio intermunicipal.

\footnotetext{
${ }^{143}$ Inclusive poderia envolver no convênio outros tipos de serviços, não se restringindo aos de saúde pública.

${ }^{144}$ Poderíamos pensar na União agindo como uma câmara de compensação, a qual transferiria valores líquidos a cada um dos Municípios envolvidos nesse convênio, a partir da aplicação de um valor "per capita" sobre a diferença entre consumidores-eleitores que demandaram serviços em sua jurisdição, e o número deles que "importaram” serviços de outros Municípios.
} 
Ampliando ainda mais o exemplo, se imaginarmos que o Município "importador" também é um Município "latente", então o incentivo seletivo que este deveria receber não se vincula à elevação de sua alíquota tributária ao nível utilizado pelo Município "exportador", mas sim a um incentivo "per capita" por meio de transferências financeiras verticais, tais quais as vinculadas aos programas normatizados pela União, que também lhe proporciona a capacidade de pagar eficazmente o "preço" acordado ao Município "exportador".

Neste caso, a importação de serviços, até em razão de ser de um Município "latente", não tende a se reduzir, ocasionando um desequilíbrio de políticas de alíquotas tributárias na região, na medida em que o Município "importador" puder mantê-las abaixo das praticadas pelo Município "exportador".

Novamente, há a tendência ao influxo de fatores a sua jurisdição, só que, desta vez, o resultado esperado é a prática regional de alíquotas tributárias médias mais baixas no equilíbrio.

É por isso que, intuitivamente, se houvesse a possibilidade de compensar todos os fluxos financeiros em uma espécie de "câmara intermunicipal" em razão da aquisição de serviços, então a compensação intermunicipal ocorreria com mais facilidade quanto mais semelhantes fossem os Municípios envolvidos.

Entretanto, as experiências de cooperação na área de saúde pública resultam de acordos entre Municípios assimétricos; e, embora propiciem um resultado de eficiência limitada, essas ainda seriam uma solução possível para as ineficiências da competição tributária.

Na verdade, toda esta digressão lógica sobre convênios intermunicipais vem de encontro às últimas normatizações impostas pela União ao setor de saúde pública, e que serão tratadas amiúde no quarto capítulo. De qualquer forma, essas normatizações possibilitam, por meio da regionalização desses serviços, a criação de convênios intermunicipais, para os quais a União se propõe a utilizar transferências financeiras vinculadas "per capita", compensadas em razão da origem dos consumidores-eleitores que demandam os serviços entre os Municípios.

Por isso, nos questionamos sobre o que ocorreria se anexássemos às suposições já feitas, a da existência de outra fonte de financiamento fiscal externa aos 
Municípios envolvidos, como por exemplo, as transferências vinculadas à normatizações a partir da União. De imediato, tratar-se-ia de uma fonte adicional de recursos fiscais que poderia mudar os efeitos tributários auferidos sobre as bases tributárias próprias dos Municípios envolvidos, em razão das alterações em seus respectivos graus de abstenção fiscal.

Além disso, a existência de uma fonte externa adicional de financiamento reduz aos Municípios a necessidade de receita própria, e, portanto, de incrementos nas suas alíquotas tributárias, que poderia, inclusive, dificultar o fluxo de fatores entre os Municípios da região. Com isso, conclui-se que os incentivos a participar de umo convênio intermunicipal voltados a um Município "importador" podem dispensar, no quanto lhe for possível, a receita tributária arrecadada de seus consumidores-eleitores voltada a "pagar" pelos serviços demandados de outro Município, principalmente, se este for um Município "latente".

Praticamente estamos admitindo que a integração horizontal estruturada espontaneamente como um convênio é uma ficção teórica. No entanto, isso nos permite supor que essas estruturas ocorrem com graus distintos de indução e coordenação. Inclusive, na medida em que as elites estejam mais comprometidas com as promessas de campanha ou com as normatizações da União em razão das transferências verticais, uma hipótese a ser investigada é se a União pode ou não assumir o papel de indutor e de coordenador neste cenário regional de integração horizontal dos serviços públicos de saúde.

\section{3. a União como indutora da cooperação, seja convênios ou coalizões}

Precede qualquer ação da União no sentido de induzir ou mesmo de coordenar a formatação de uma cooperação, a tomada de decisão das elites políticas envolvidas em cooperar ou não. E, embora essa escolha possa ser influenciada pelos incentivos propostos, ela ainda é uma atribuição às elites políticas municipais. Até porque, nada garante que os compromissos com as normatizações, advindos dos 
incentivos propostos, dominem as relações entre a União e as elites políticas municipais.

Ou seja, embora seja possível tratar-se a relação existente entre esses personagens à semelhança de uma relação ${ }^{145}$ agente-principal, ainda assim, sob o enfoque federativo, devem ser considerados como entes politicamente iguais. Inclusive, o último capítulo deste trabalho será dedicado à descrição da evolução histórica das alterações normativas e da forma com que a União imprime a coordenação, ao mesmo tempo em que monitora os resultados por meio de organizações supra-municipais criadas para esse fim.

Devemos estar cientes de que a União entra neste jogo na posse de atributos e ferramentais suficientes para assumir a função de indutora à cooperação. Entre eles, a normatização da regionalização da prestação de serviços públicos de saúde e das transferências verticais.

Além disso, com a edição de uma norma pró-regionalização em 2001, a União passou a sinalizar a intenção de assumir o papel de indutor à cooperação; inclusive, minimizando o custo político de elites políticas municipais em estruturá-la, e ampliando a motivação destas à cooperação, espera-se que tomem a decisão de constituir uma estrutura cooperativa.

O que significa, também, dizer que a regulamentação da União pode encontrar apoio nas decisões dos Municípios aderirem à cooperação, tomadas por eles em seus respectivos ambientes político-eleitorais. E, por mais que essas decisões se dêem no âmbito das racionalidades limitadas, ainda assim, elas expressariam a diferença de avaliação que as elites políticas envolvidas e os respectivos grupos de consumidores-eleitores fazem da incerteza e do risco de se aderir ou não a alguma forma de cooperação.

\footnotetext{
${ }^{145}$ Nesta questão, é interessante salientarmos a correlação dos incentivos propostos pela União aos Municípios em meio à estrutura federativa. Ou seja, como um mesmo consumidor-eleitor se faz representar nas três esferas de governo, e, dado que é atribuída constitucionalmente à União a capacidade de emitir as normas gerais, inclusive as de políticas públicas, então permeia pela estrutura federativa brasileira um "contra-fluxo hierárquico" de tomada de decisão, que no caso da política pública de saúde, que principia pela normatização da União, envolvendo os governos estaduais, e principalmente, os municipais. Ressalte-se que essa mesma estrutura federativa confere aos Municípios em geral, a tarefa de prestar os serviços de saúde pública.
} 
Em suma, qualquer uma das estruturas de cooperação surge quando os agentes cooperam para alcançar uma meta em comum, a qual, pode ser estruturada por um contrato, formal ou não, que expresse o cálculo de otimização que cada uma das partes faz da organização, desde que satisfaça um interesse mútuo projetado.

É inegável à União a sua capacidade de indução. As normas editadas por ela e as suas transferências verticais proporcionam-lhe um mecanismo de coerção muito eficiente na indução à cooperação intermunicipal. Porém, é necessário que este também seja o seu objetivo.

Afinal, conceitos como cooperação e investimento se relacionam tanto com a busca da eficiência e da expansão da capacidade prestadora de serviço, quanto com a agregação de informações junto à União, embora, se reconheça a sua restrita capacidade de concentrar plena informação sobre todas as preferências individuais e tecnologias de produção, o que, de certa forma, limita também a sua capacidade de coordenação. Também nada garante que a União possa realocar recursos de modo que todos os consumidores-eleitores estejam melhor do que estariam se os Municípios buscassem seus equilíbrios isoladamente.

Porém, não encontramos outro ente na estrutura federativa brasileira que melhor possa desempenhar o papel de coordenação e de regulamentação da cooperação intermunicipal do que a União. Afinal, ela pode sincronizar a demanda e a oferta de serviços de saúde pública, regulamentar a prestação regional, produzir efeitos redistributivos, facilitar a propagação de informações, reduzir os custos políticos, realçar a cooperação nas relações intermunicipais, induzir a internalização dos custos sociais de externalidades negativas, e patrocinar e promover a universalização do acesso a um dado padrão de serviços.

\section{4. algumas considerações}

No ano de 2001, a União editou suas primeiras normas especificamente voltadas a estruturas de cooperação na forma de convênios. E, nesse momento, cerca de um terço dos Municípios brasileiros já se encontravam envolvidos em coalizões. 
Ou seja, em paralelo à evolução institucional das políticas públicas elaboradas pela União, construíram-se algumas estruturas organizacionais e institucionais voltadas à prestação de serviços públicos de saúde em algumas regiões, na medida em que suas respectivas elites políticas puderam mudar as estruturas fiscais, ainda que acompanhadas de custos políticos, e proporcionar a universalização do acesso ao serviço público de saúde aos seus residentes.

Por isso, tivemos neste capítulo, a preocupação de evidenciar aspectos que conduzam as elites municipais a adotar um padrão mais cooperativo nas ações de saúde pública, que não necessariamente estejam vinculados à normatização da União, até porque a maioria dos casos existentes, embora sejam viabilizados financeiramente por transferências desta, não necessariamente tiveram suas motivações e incentivos à sua constituição a partir de ações institucionalizadas por ela.

Vimos que a percepção que se tem da competição tributária é que ela conduz a alíquotas tributárias ineficientemente baixas; e, que a literatura identifica circunstâncias sob as quais outras ineficiências acontecem motivadas por instrumentos não tributários. Também vimos que a competição intermunicipal pode ter aspectos benéficos, quando conjugada ao processo político envolvendo o auto-interesse das elites políticas envolvidas em estruturar ou manter a cooperação, na medida em que as induz a reduzir o desperdício no gasto público.

Esta possibilidade nos devolve ao contraste entre a eficiência do mundo de Tiebout com a ineficiência observada nos modelos de competição tributária pela provisão de bens e serviços, uma vez que estes modelos praticamente re-introduzem as falhas de um mercado competitivo.

Ou seja, a abordagem política da competição intermunicipal, por um lado, segue a abordagem de Tiebout, ao reconhecer que esta competição introduz incentivos que realçam a eficiência, motivando os consumidores-eleitores proprietários de fatores a encarar a competição. Por outro lado, a partir do mundo de Tiebout, reconhece-se que esses incentivos ocorrem em mercados com falhas que provocam um equilíbrio ineficiente na oferta de serviços públicos.

Portanto, a competição intermunicipal tem aspectos bons e ruins, que varia com o padrão dos serviços que os governos provêem; o que sugere um papel de 
regulamentador sobre as várias políticas públicas a uma autoridade central, no caso a União, embora sujeita aos problemas de informação assimétrica, voltada às suas funções alocativas e distributivas.

No que se refere ao orçamento público, nossa ênfase recaiu sobre o lado dos gastos públicos de saúde, com foco em externalidades, buscando na tomada de decisão das elites políticas as variáveis "do quanto" e "onde" empregar os recursos fiscais.

Também abordamos a motivação das decisões das elites políticas em constituir uma estrutura de cooperação, e, por consequiência, o perfil dos gastos fiscais. Por isso, procuramos identificar as variáveis tais como o compromisso político e o grau de comportamento oportunístico.

Ao longo da descrição destas variáveis, evidenciou-se, novamente, a necessidade de uma autoridade central que também coordenasse, em algum grau, a cooperação entre as diversas elites políticas municipais para a consecução da política de saúde pública. Também se evidenciou que, para que se estruture a cooperação intermunicipal, há que se considerar na função objetivo das elites políticas municipais a motivação a partir da obtenção dos "bônus políticos", (expresso em votos).

Tal qual a decisão dos grupos de consumidores-eleitores em decidir entre estruturar ou não a cooperação, apoiado nas variáveis ideologia e promessa de consumo futuro, a motivação à cooperação intermunicipal também pode ser vista como que variando numa escala polarizada entre a ação espontânea e a ação totalmente induzida; em um ambiente político institucional regulamentado pela União.

Com relação ao primeiro pólo, o da ação plenamente espontânea, caracterizase pela ocorrência, num primeiro movimento, da tomada de decisão unânime de diversas elites políticas municipais pelo empreendimento de políticas públicas conjuntas de saúde. Neste processo de tomada de decisão, aparentemente, se dispensa a ação indutora de uma autoridade central.

No entanto, esta autoridade central, num segundo movimento, poderia até ser eleita pelos entes envolvidos como o ente certificador e avalisador do contrato firmado, até porque a maioria dos Municípios são receptores líquidos dos recursos provenientes das transferências financeiras verticais, em geral vinculadas à regulamentação da União. 
Além disso, a mobilização das elites políticas municipais pode ocorrer na direção da constituição de uma entidade coordenadora das ações conjuntas de saúde pública na região. Afinal, numa situação de alto grau de espontaneidade, os entes federativos diretamente envolvidos poderiam estabelecer suas próprias regras de cooperação, delegando a uma estrutura organizacional criada para esse fim, tal qual a coalizão, a capacidade de monitorar as ações empreendidas pelas diversas elites políticas.

Trata-se de uma solução de cunho federativo, eminentemente "de baixo para cima”. E, infere-se neste caso, que as motivações das elites políticas municipais para a constituição de uma coalizão seriam inversamente relacionadas com a variação do tipo dos respectivos grupos jurisdicionais de consumidores-eleitores, quando classificados de "monopsônicos" a "latentes".

Para o outro pólo, o da estruturação totalmente induzida, principia por se considerar que o federalismo fiscal brasileiro regrado no contrato constitucional vigente confere à União a capacidade de legislar matéria de "norma geral" da política publica de saúde. As primeiras normas regulamentadoras, além do caráter intrinsecamente normativo, basicamente condicionaram as transferências de recursos financeiros aos diversos Municípios e Estadas, voltadas à produção de serviços públicos de saúde autônomos, com a adoção de determinados procedimentos pré-estabelecidos.

Dessa forma, a autoridade central na pessoa da União, toma a iniciativa "de cima para baixo" de institucionalizar e regrar o serviço público de saúde, criando órgãos certificadores multi-representativos nas diversas instâncias federativas, ampliando a credibilidade da aplicação de sansões pelo descumprimento dos procedimentos pré-estabelecidos. Obviamente a capacidade coercitiva dessas normas se vinculava ao interesse pelos recursos financeiros das elites políticas em, com eles, satisfazerem seus compromissos políticos de oferta de saúde pública aos seus respectivos consumidores-eleitores.

No quarto capítulo será possível observar que a possibilidade da cooperação intermunicipal não foi prevista nas primeiras normas, onde, reforce-se, a intenção se vinculava na relação biunívoca União e Município das condições para que um dado Município fosse contemplado por uma parcela de transferência financeira, suscitando 
entre outros, competição fiscal horizontal, pela disputa de maior participação nessa distribuição.

Pois, como já observamos, a primeira norma a incorporar algum caráter contratualista ocorreu em 2001, com a edição da NOAS-SUS 01/01. Com ela, a União busca uma solução interpolarizada, induzindo a estruturação da cooperação intermunicipal numa determinada região sob a forma de convênio, estabelecendo critérios de compensação financeira entre Municípios "importadores" e "exportadores" de serviços públicos de saúde, com uma transferência financeira "per capita".

Assim, prosseguimos nosso trabalho tratando, nos capítulos seguintes, de estudar essas situações acima evidenciadas na realidade brasileira da política pública de saúde. A cooperação intermunicipal tendente a espontânea, com a constituição de uma coalizão; e, a tendente a induzida, estudando como as mudanças institucionais empreendidas pela própria União a conduziram à normatização da implantação de convênios intermunicipais. Note-se que ambas as situações não conseguem prescindir totalmente de algum incentivo externo e de coordenação. 


\section{CAPÍTULO III}

\section{O DESENHO CONTRATUAL DE ESTRUTURAS DE GOVERNANÇAS DE UMA COALIZÃO INTERMUNICIPAL DE SAÚDE}

\section{1. apresentação}

O enfoque deste capítulo é a análise da estrutura de governança intermunicipal de uma coalizão, cuja organização da cooperação intermunicipal se dá na forma de um consórcio. Nosso enfoque estará na criação e na gestão dessa estrutura de cooperação voltada ao setor de saúde pública.

Em razão da limitada bibliografia sobre o tema deste capítulo, recorremos à adaptação da literatura sobre os mercados de franchising ${ }^{146}$ para a situação desenhada, com o objetivo de explicar a situação em que várias elites políticas municipais tomam a iniciativa de criar uma entidade supra municipal, de modo a fornecer serviços públicos de saúde, aproveitando-se de economias de escala e solvendo problemas de externalidades.

Portanto, este capítulo apresentará um estudo das coalizões intermunicipais, focado no pioneirismo do Consórcio Intermunicipal de Saúde de Penápolis - CISA; identificando os "riscos contratuais" presentes nas relações existentes no fornecimento dos serviços especializados prestados pelo consórcio, e as suas implicações em termos de governança; e, como a criação de uma personalidade jurídica, o consórcio, modela a arquitetura contratual desta estrutura de governança, de modo a proporcionar a maximização da equidade ${ }^{147}$ entre os envolvidos.

\footnotetext{
${ }^{146}$ Uma definição para "franchising" é a organização da cooperação em rede para o provimento de um bem ou serviço coletivo.

147 Segundo Williamson (1986), para que o desenho contratual se revista de equidade entre os envolvidos, fazem-se necessárias algumas considerações. Uma primeira é a que propõe igual oportunidade de participação a todos (desde que estejam aptos a terem custos de desmoralização; embora a participação seja valorizada pelo seu próprio motivo). Uma outra observação é a que diz respeito às questões não previstas no contrato constitutivo, podendo-se caracterizá-las como surpresa a partir da legítima presunção de que não existe contrato completo, condicionada a não ser efeito de algum
} 


\section{2. a coalizão na forma de consórcios intermunicipais de saúde}

\section{1. organizando a cooperação}

$\mathrm{Na}$ verdade os consórcios representam parcerias entre Municípios voltadas ao provimento de especialistas ou serviços médicos, ambulatoriais e laboratoriais de maior complexidade, envolvendo principalmente Municípios de pequeno e de médio porte. Em geral, criam-se organizações privadas que administram os fundos públicos alocados por sistemas de cotas fixas e por critérios de uso.

Desse modo, Ribeiro e Costa (1999) destacam algumas condicionantes empíricas observadas em questões sobre essa modalidade de coalizão intermunicipal, destacando que as associações “(...) decorrem da fragilidade de Municípios de pequeno porte que passam a atuar como compradores de serviços junto ao Município-sede, capitalizando a sua oferta e gerando economia de escala; induzem à auto-exclusão dos governos estaduais, com o desinvestimento pela transferência do interesse político dessa área aos Municípios, mantendo as funções de regionalização e hierarquização da assistência à saúde; e, são uma cooperação local que amplia as coalizões políticas e a qualidade de governo" .

Interessante neste momento é caracterizar juridicamente o consórcio. O consórcio intermunicipal mencionado na Lei ${ }^{\circ} 8.080 / 90^{148}$, segundo Carvalho e Santos

comportamento oportunístico; e, para essa exceção, deve-se prever uma regra de como lidar com essa situação, conquanto não provoque a renegociação do contrato. E, por último, a equidade impõe a proteção das minorias, na medida em que, no transcurso da barganha pela forma do contrato, muito provavelmente as minorias envolvidas são "vítimas" freqüentes de informação assimétrica, principalmente naqueles casos onde os efeitos da reputação "ex-post" são fracos, reduzindo a eficiência do controle social.

148 A Lei Orgânica da Saúde (Lei n. ${ }^{\circ}$ 8.080, de 19 de setembro de 1990), ao dispor sobre a organização, direção e gestão do Sistema, trata dos consórcios municipais. Assim é que em seu Artigo 10, essa Lei especifica: "os municípios poderão constituir consórcios para desenvolver, em conjunto, as ações e os serviços de saúde que lhe correspondam" . No parágrafo $1^{\circ}$ desse mesmo Artigo, resguarda, no entanto, que "aplica-se aos consórcios administrativos intermunicipais o princípio de direção única e os 
(1995) pode ser definido como “(...) um acordo entre entidades da mesma espécie: Estados entre si, Municípios entre si, autarquias entre si, fundações entre si. Nesse aspecto, difere do convênio, que pode congregar pessoas jurídicas de espécie diferente". Além do mais, exige-se a formulação de uma pessoa jurídica que pode ter a sua existência limitada no tempo conforme as necessidades do empreendimento, necessariamente de caráter privado, para administrá-las.

Esse tipo de consórcio intermunicipal é diferente dos consórcios de economia de mercado, pois as parcerias se dão no setor público: "Vale lembrar que o consórcio intermunicipal não se confunde como consórcio de empresas previsto na Lei de Sociedade por Ações e na Lei de Mercado de Capitais, nem com o consórcio de empresas para fins de licitação (...). O único ponto de contato entre esses consórcios (formalizados em contrato particular) e o consórcio administrativo intermunicipal está em que uns e outro se destinam a congregar esforços e recursos para um fim determinado. Porém, enquanto os consórcios de empresas não podem formar uma pessoa jurídica porque então seria uma outra entidade, distinta das empresas consorciadas, igualmente de natureza privada, o consórcio de Municípios tem a necessidade de criar uma pessoa jurídica privada, uma vez que os Municípios são entidades estatais, políticas, e não poderiam agir em conjunto a não ser por intermédio de uma pessoa jurídica”. Obviamente, concluem Carvalho e Santos (1995, p. 112), “de natureza jurídica privada” .

Ou seja, a adesão dos Municípios depende da aprovação pelas Câmaras Municipais e “(...) a pessoa jurídica de direito privado, criada pelos Municípios consorciados, deverá, no nosso entender, se pautar pelos princípios básicos que informam as atividades da administração pública, uma vez que os recursos que irá administrar são recursos públicos ", segundo Carvalho e Santos (1995, p. 113).

Definido juridicamente o que seja um consórcio formado por pessoas de direito público, nosso foco volta-se aos aspectos econômicos e motivacionais de sua formação. Identificamos, nos capítulos anteriores, alguns estímulos à estruturação de

respectivos atos constitutivos disporão sobre sua observância" . Já no seu Artigo 18, inciso III, expressa ainda a competência municipal para "formar consórcios administrativos intermunicipais" . 
uma cooperação que, neste caso, se formata como uma coalizão, os quais se aplicariam aos consórcios intermunicipais.

Um desses estímulos teria origem na existência de um pólo de prestação de serviços de saúde na microregião, ou seja, haveria um Município, provavelmente "monopsônico" ou "privilegiado" que já atraísse a migração de consumidores-eleitores dos Municípios vizinhos, principalmente dos "latentes". Um segundo estímulo, viria da baixa oferta de serviços de saúde de maior complexidade tecnológica ou de especialistas médicos na região; provavelmente estaríamos falando de Municípios "privilegiados" e "intermediários" que, com algum esforço de coordenação, se coligariam para a prestação desses serviços complementares, atraindo, conforme os incentivos seletivos direcionados à região, os Municípios "latentes".

Além desses estímulos, um terceiro poderia ser identificado com o fluxo de recursos financeiros oriundos da União, quando associado aos gastos municipais no setor de saúde pública, providos por um consórcio. Especificamente, nesse processo, há que se mencionar que os governos estaduais também aportaram recursos nessas coalizões, conquanto essas organizações semipúblicas sejam constituídas conforme o padrão de oferta de serviços dominante na regionalização da política de saúde dentro do Estado, de modo a atender as necessidades dos consumidores-eleitores na região em razão do respectivo grau de mobilidade interjurisdicional.

Assim sendo, motivadas pelo ganho de escala, essas coalizões intermunicipais criaram novas organizações que gerenciam fundos públicos de uma forma mais flexível. Essas organizações, embora entidades semipúblicas, sinalizam qualidade aos consumidores-eleitores na medida em que propõem incentivos e melhores condições de contratação de pessoal e serviços especializados.

Ou seja, os consórcios são financiados e dirigidos por órgãos públicos, envolvendo a participação das comunidades no planejamento das atividades através de órgãos regulamentadores - os Conselhos Municipais de Saúde - que exercem a função de controle social ${ }^{149}$, adotando as tradições e as normas da União. Esses Conselhos

\footnotetext{
149 Controle Social é aqui entendido como o controle sobre o Estado pelo conjunto da sociedade organizada sobre as políticas públicas de saúde, devendo se estender a todos os segmentos sociais. Evidentemente, esse controle deve visar o benefício do conjunto da sociedade, deve ser permanente, e
} 
reservam-se, como organismos colegiados, as funções de difusão das informações das elites políticas envolvidas, dos provedores e dos profissionais, a todos os consumidoreseleitores da região.

Como os consórcios intermunicipais são a organização da parceria entre diversas elites políticas, a confiança política mútua e as peculiaridades de cada política municipal acabam por influenciá-los, como abordado no capítulo anterior. Porém, os interesses dessas elites políticas nos consórcios acabam, de uma certa forma, sendo processados pela burocracia do consórcio, como uma estratégia para ampliar a sua própria autonomia e assegurar algum nível de isolamento das várias posturas políticas municipais.

Os problemas surgem a partir de como os resultados dessa coalizão são capturados pelos consumidores-eleitores. Porém, se positivos, "incentivam" a agregação das elites políticas municipais, neutralizando tanto a fragmentação de interesses, quanto o problema de governabilidade causado pela divisão dos bônus políticos desse sucesso, em geral, com tendência à elite política cujo Município sedia o consórcio ou centraliza a oferta dos principais serviços.

Dessa forma, a expectativa pelos resultados no que tange à qualidade dos serviços e à facilidade de acesso, além de explicar a agregação de elites políticas, muitas vezes de diferentes partidos políticos, e da agregação de estruturas municipais muitas vezes diferentes entre si; também justifica as elites políticas dos Municípios envolvidos, o repasse para o Município-sede dos recursos transferidos da União alocados em cada um deles, assim como o pagamento da cota mensal proveniente do Tesouro municipal para o fundo comum.

Ou seja, as elites políticas, principalmente dos Municípios que "gravitam" em torno do Município-sede do consórcio, em geral, os classificados por "latentes",

deve expressar a "voz" da maioria dos consumidores-eleitores. Por isso, quanto mais os segmentos da sociedade se mobilizarem, se organizarem, e se fizerem representar, maior será a pressão e o resultado, para que seja efetivado o Estado Democrático. Todas as formas de pressão e controle dão-se por iniciativas preponderantes dos movimentos e entidades da sociedade organizada. Portanto, o controle social também seria a resultante da articulação e da negociação dos interesses fracionados e específicos de cada segmento, a favor dos interesses e direitos de cidadania do conjunto da sociedade. E, toda a vez que for exercido o direito de voz pelo conjunto das entidades e instituições da sociedade organizada, tende a ser o controle mais efetivo e legítimo, a favor do conjunto da sociedade. 
procuram apresentar a idéia ${ }^{150}$ de uma estruturação da cooperação na forma de coalizão aos seus consumidores-eleitores residentes como uma ampliação, quando não, a obtenção de benefícios, decorrente de seu "espírito inovador e empreendedor ".

Quanto à concentração de serviços muitas vezes possível de ocorrer no Município-sede, as elites políticas envolvidas justificam-se por conceitos técnicos de economia de escala. Por outro lado, essas mesmas elites políticas também afirmam pela necessidade de que algumas ações de saúde pública sejam descentralizadas, até mesmo para justificar a distribuição de bônus políticos entre elas, ou mesmo, para ampliar outros ${ }^{151}$ benefícios aos consumidores-eleitores no Município de sua residência.

\section{2. os consórcios intermunicipais de saúde no Brasil}

A tabela II informa os consórcios intermunicipais de saúde existentes em outubro de 1997 no Brasil, por Estado. Ela demonstra que os consórcios intermunicipais de saúde já estavam amplamente difundidos no Brasil, com cerca de 15\% da população brasileira tendo acesso em 1997.

Perceba-se que, nos Estados ${ }^{152}$ de Minas Gerais e Paraná, a abrangência populacional, já em 1997 era altamente significativa, em reflexo ao comportamento coordenador que as respectivas Secretarias de Saúde exerciam.

Do estudo de Ribeiro e Costa (1999), constata-se que os consórcios intermunicipais de saúde no Brasil têm adquirido uma dimensão ampliada na gestão de política pública voltada à saúde ${ }^{153}$, dados os seguintes fatores: a existência de coligação

\footnotetext{
150 Ainda que na ótica de compra de serviços, em meio a relações políticas assimétricas, e conseqüentemente, com transferência de receita para o Município-sede.

${ }^{151}$ Por exemplo, transporte, posto local de coleta, central de consultas, etc...

152 Mais recentemente, a Secretaria de Saúde do Estado do Rio Grande do Sul também empenhou esforços de coordenação e incentivos na constituição de consócios, o que certamente se refletiria numa atualização dos dados da tabela 2.

${ }^{153}$ O Ministério da Saúde divulgou que os consórcios intermunicipais de saúde no Brasil, em 1999, já teriam totalizado 143, envolvendo 1.740 Municípios de todas as regiões. Note-se que esses expressivos
} 
partidária entre os participantes voltada à sustentação do consórcio; a indução e eventual financiamento de governos estaduais à constituição dos consórcios; a distribuição homogênea dos benefícios entre os participantes; a ampliação da oferta de serviços ambulatoriais entre os consorciados; o financiamento solidário por cotas mensais entre os envolvidos, cuja suscetibilidade depende da percepção de ganhos coletivos entre as elites políticas envolvidas, e entre os consumidores-eleitores; e, os efeitos positivos decorrentes da durabilidade da parceria e da inexistência de ação predatória do Município-sede (maior ofertante) sobre os demais.

Tabela II -Consórcios intermunicipais de saúde existentes em outubro de 1997

\begin{tabular}{|c|c|c|c|c|c|}
\hline Região/Estado & $\begin{array}{c}\mathrm{N}^{\mathbf{0}} \mathrm{de} \\
\text { Consórcios } \\
\text { Informados }\end{array}$ & $\begin{array}{c}\mathrm{N}^{\circ} \text { de Municípios } \\
\text { Envolvidos }\end{array}$ & $\begin{array}{c}\text { \% sobre o } \\
\text { Total de } \\
\text { Municípios }\end{array}$ & $\begin{array}{l}\text { População } \\
\text { Coberta }\end{array}$ & $\begin{array}{c}\text { \% sobre o } \\
\text { Total da } \\
\text { População }\end{array}$ \\
\hline Norte & - & - & - & - & \\
\hline Nordeste & 1 & 10 & 0,64 & 94.000 & $\mathbf{0 , 2 1}$ \\
\hline Paraíba & 1 & 10 & 5,85 & 94.000 & 2,79 \\
\hline Sudeste & & & $\overline{61,64}$ & & 24,23 \\
\hline Espírito Santo & 5 & 47 & 66,20 & 978.545 & 34,59 \\
\hline Minas Gerais & 63 & 725 & 95,90 & 10.760 .755 & 64,51 \\
\hline São Paulo & 14 & 173 & 27,68 & 4.517 .562 & 13,22 \\
\hline Sul & 23 & 405 & 38,28 & $\overline{5.811 .801}$ & 24,88 \\
\hline Paraná & 16 & 280 & 75,47 & 4.496 .932 & 51,26 \\
\hline $\begin{array}{l}\text { Rio Grande do } \\
\text { Sul }\end{array}$ & 2 & 51 & 11,94 & 520.000 & 5,37 \\
\hline Santa Catarina & 5 & 74 & 28,46 & 794.869 & 16,21 \\
\hline Centro-Oeste & 3 & 26 & 6,07 & $\overline{497.666}$ & 4,76 \\
\hline Mato Grosso & 3 & 26 & 22,03 & 497.666 & 20,92 \\
\hline TOTAL & 109 & 1.386 & 27,85 & 22.660 .329 & $\overline{14,35}$ \\
\hline
\end{tabular}

Fonte: Ministério da Saúde. Secretarias Estaduais de Saúde. IBGE de 1996.

números ocorrem antes da vigência da NOAS-SUS 01/01, que normatiza a regionalização dos serviços públicos de saúde. 
Além disso, dado o tipo de administração e as suas regras de funcionamento $^{154}$, os consórcios acabaram se situando entre as inúmeras fórmulas desenvolvidas no setor saúde pública, voltadas a flexibilizar mecanismos de aquisição de equipamentos e a contratação de pessoal, sendo agrupados como organizações semipúblicas; mesmo não existindo registros precisos sobre os consórcios intermunicipais de saúde no Brasil, até porque a sua existência não é pré-requisito para habilitação ou financiamento de Municípios por meio das transferências financeiras normatizadas pela União, ou para o recebimento de incentivos financeiros específicos de qualquer espécie por parte do Ministério da Saúde - MS.

Dessa forma, os consórcios, como uma forma de regionalização da oferta pública de serviços de saúde, inserem-se em meio a políticas de redução de barreiras de acesso ao consumidor-eleitor e de descentralização dos serviços públicos. Porém, há uma barreira legal que será, inclusive, observada mais amiúde à frente, que tem efeito na postura assumida por alguns Tribunais de Contas Estaduais - TCE's, pela qual os consórcios acabam tendo uma baixa "tradição de contratação".

Uma outra "barreira" a ser transposta pelos Municípios a se coligarem é o fato de que a aprovação da regulamentação dos consórcios depende de decisões coletivas dos Conselhos Municipais de Saúde envolvidos, que são os que detêm o controle social das ações de saúde pública. E, além disso, dentro desse contexto político-legal, a sustentabilidade financeira dos consórcios também é dependente dos laços políticos estabelecidos entre as várias elites políticas municipais envolvidas na coalizão.

\footnotetext{
154 As regras de funcionamento, em geral, segundo Ostrom (1986), especificam conjuntos de ações ou resultados que podem ser desenhadas de várias formas: podem determinar que algumas ações ou resultados particulares estão proibidos; podem enumerar ações e resultados específicos ou estabelecer limites das ações e resultados permitidos, proibindo aquelas que não estão especificamente incluídas; e, por último, as regras podem ser do tipo dirigido, requerendo uma ação ou resultado específico. Observese que, neste ultimo caso, os envolvidos na formatação de um contrato "auto-coercitivo" devem estabelecer uma, e, somente uma ação, ao invés de permitirem-se escolher dentro de um conjunto de possíveis ações; por isso mesmo, este tipo de regra de funcionamento é menos utilizado para se estruturarem situações futuras do que os demais, embora sua existência, adequada num contrato, pode conferir a este, uma maior credibilidade.
} 


\section{3. os consórcios intermunicipais de saúde e a União (por meio do SUS)}

Em geral, os consórcios são uma solução voltada à contratação de profissionais especializados, provendo incentivos destinados tanto a atraí-los, competindo com o mercado privado, quanto a induzir uma melhor qualidade do serviço público prestado. As razões estão nas motivações das elites políticas envolvidas, que assumem a condição de agentes promotores de mudanças na prestação de serviços públicos na região, voltadas não somente a integrar, mas também a complementar as ações normatizadas pela União.

Desse modo, os consórcios intermunicipais de saúde podem ser vistos como uma "participação ampliada" do processo de municipalização desta política pública, na forma de parcerias entre Municípios próximos, por meio de uma coalizão entre os gestores do sistema de saúde, definindo regras de financiamento dos serviços, que por sua vez, determinam as regras de acesso dos consumidores-eleitores oriundos dos Municípios associados.

No apoio, alguns governos estaduais têm contribuído com recursos técnicos e financeiros para fomentar essa forma de parceria intermunicipal que vise ampliar a oferta de especialistas médicos ou de serviços de maior densidade tecnológica, possível somente numa escala compatível com uma coalizão intermunicipal.

Embora as primeiras experiências de coalizões foram desenvolvidas a partir de $1986^{155}$; somente foram regulamentados em 1990 em alguns dispositivos da Lei Orgânica da Saúde, a Lei n ${ }^{8} .080 / 90$. Porém, isso não significa que a formação de consórcios na área de saúde não tenha sido estimulada por meio de dispositivos normatizadores emitidos pela União, principalmente a partir da Norma Operacional Básica de 1996 - NOB 96. Embora, nessa norma, praticamente, a União tenha se restringido a reconhecer a sua existência.

Posteriormente, o Ministério da Saúde, por meio de sua Secretaria de Políticas de Saúde e de Avaliação, editou o documento "O Consórcio e a Gestão Municipal em Saúde” que se destina a apoiar as elites políticas municipais nesse tipo de

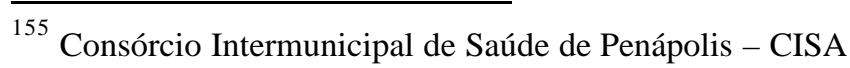


iniciativa. Por esse documento, o Ministério da Saúde deixa claro que a constituição de consórcio é uma iniciativa autônoma das elites políticas municipais, estabelecida pela Constituição Federal de 1988.

Observe-se que essa mesma Constituição Federal institui o Sistema Único de Saúde - SUS, e, embora esta organização seja objeto de uma abordagem mais amiúde no capítulo seguinte, podemos adiantar que ela surgiu, além dos princípios constitucionais promulgados em 1988, também com base em arranjos decididos pela União voltados ao acesso universal de toda população aos serviços públicos de saúde, os quais instituem padrões mínimos de ações a serem induzidos aos Municípios, para que estes os empreendam individualmente.

E, em meio a esse ambiente institucional, já pudemos identificar alguns incentivos à constituição de coalizões intermunicipais, com a publicação das leis específicas da saúde - Lei $n^{\circ} 8080 / 90$ e Lei $n^{\circ} 8142 / 90$, as quais definem que os consórcios intermunicipais podem integrar o Sistema Único de Saúde - SUS.

Por outro lado, esses incentivos se circunscreveram à criação de consórcios na medida em que proporcionassem as condições favoráveis para que os Municípios envolvidos assumissem as responsabilidades individuais pela respectiva gestão de seu sistema autônomo de saúde, ainda que na condição de "compradores" dos serviços prestados pelo consórcio. E a criação de consórcios foi uma forma de os Municípios atenderem aos parâmetros estabelecidos pela NOB SUS 01/96.

No entanto, a União tinha uma postura estritamente normatizadora, atrelada ao conceito de municipalização das ações de saúde pública. Note-se que a regionalização dos serviços só ocorre com a NOAS-SUS 01/01, ainda que esta norma não descole do conceito de municipalização.

De qualquer forma, o consórcio de saúde passou a ser um instrumento na gestão pública voltada a potencializar a atenção básica da saúde das populações, contribuindo para a consolidação do SUS. Por outro lado, como os consórcios representam a união dos diversos recursos disponíveis nos Municípios envolvidos, para a solução de problemas e objetivos comuns, cada uma dessas coalizões pode assumir características próprias decorrentes das peculiaridades dos Municípios envolvidos e da região. 
E assim sendo, com a elaboração do Plano de Ações e Metas Prioritárias para 1997/98, a União, por meio do SUS, estabeleceu estímulos à criação de consórcios intermunicipais ${ }^{156}$. Evidentemente, ante as necessidades municipais, e, com a indução institucional da NOAS-SUS, essa modalidade de cooperação difundiu-se ainda mais pelo país; principalmente naqueles Estados onde seus respectivos governos, que assumiram o papel de coordenação, ofereceram incentivos para a constituição de coalizões intermunicipais, inclusive, com aportes de recursos à sua estabilidade financeira, mas, provavelmente, condicionados a alinhar-se aos interesses estaduais para a região.

Ressalte-se que, alinhado à função redistributiva da União, uma das prioridades do SUS é compensação das desigualdades regionais, não só por meio de uma ação pautada em objetivos políticos, mas também nos arranjos decisórios dos governos federal, estaduais e municipais, e de suas decisões normativas como no caso do PAB (Piso de Atenção Básica definido pela Norma Operacional Básica SUS - 96, calculado sobre a base populacional, podendo ser ampliado com a implementação de programas locais), e mais recentemente no PPI (Programação Pactuada e Integrada) por meio da NOAS-SUS 01/01.

As transferências de recursos financeiros voltados às ações ambulatoriais e hospitalares no âmbito do SUS, realizados da União para Estados e Municípios, respondem a duas influências básicas: (a) à ação de elites políticas junto a agências governamentais e ao Congresso Nacional para capturar recursos orçamentários para as suas regiões; e (b) aos parâmetros técnicos de alocação financeira que são determinados por organismos colegiados para a regulação do SUS, como as Comissões Intergestoras e os Conselhos de Saúde (Costa e Ribeiro, 1996).

No entanto, veremos no próximo capítulo que essas influências dependeram das normas editadas pela União, em especial a NOB-SUS 01/93 que ampliou a intervenção dos organismos colegiados reguladores na condução das ações voltadas ao setor de saúde pública, substituindo a ação clientelista das elites políticas por uma ação tecnicista dentro do conceito de controle social da gestão de políticas públicas.

\footnotetext{
${ }^{156}$ Provavelmente, foi a partir dos resultados auferidos desses incentivos que a União, por meio do SUS, edita a NOAS-SUS 01/01, na qual institucionaliza a regionalização do serviço público de saúde.
} 
Essa intervenção foi ampliada com a NOB-SUS 01/96, que reforçou as funções redistributivas do SUS, ao orientar mais recursos às regiões mais pobres, ou seja, regiões onde a maioria dos Municípios é formada por grupos de consumidoreseleitores de maioria "latente", movimento este que tende a se consolidar com a NOASSUS 01/01.

\section{4. as regras em um consórcio intermunicipal de saúde}

Dado que a criação de um consórcio entre Municípios é voltada para a oferta comum de serviços de saúde pública, cujo esforço deve ser compartilhado entre todos os envolvidos, é racional esperarmos por um comportamento oportunístico de algum deles. Como já observado em capítulo anterior, seria racional esperar que isso acontecesse, o que realça a importância do estudo da governança dessa coalizão.

Para uma coalizão ser considerada uma instituição estável, é necessário que suas regras sejam críveis, ou seja, devem-se analisar como elas afetam comportamento dos personagens envolvidos.

Segundo Ostrom (1986), seria necessário se definir como a estrutura na qual uma determinada situação está operando, para então se analisar como uma determinada regra irá operar. Afinal, as regras operam de maneiras diferentes em estruturas diferentes. Além disso, as regras também têm características configuracionais, ou seja, um determinado resultado previsto para uma determinada situação, sob uma determinada regra, não dependeria apenas dessa regra, mas também das outras regras que estão operando conjuntamente ${ }^{157}$.

De qualquer forma, essas regras são as que regulamentam a qualidade e o acesso ao serviço prestado, e precisam serem estabelecidas dentro de uma estratégia de “mercado ${ }^{158}$ comum”, em conjunto com um sistema de "coerção". Daí a preocupação

\footnotetext{
${ }^{157}$ O que nos remete ao conceito de complementariedade das políticas públicas.

${ }^{158}$ A razão de trazer a noção de mercado atrela-se à necessidade de se ajustar oferta à demanda reprimida dos consumidores-eleitores, podendo até ser para além daquilo que seria considerado o nível de atenção básico normatizado pelo SUS. Isso não necessariamente significa que a cada prestação de serviço de
} 
com que a entidade supra municipal seja criada como pessoa jurídica de direito privado, a fim de facilitar a eficiência administrativa, na medida em que lhe proporciona algum "grau de manobra" às elites políticas envolvidas.

Embora este trabalho tenha um caráter genérico, o estudo dos mecanismos ${ }^{159}$ de governança voltados a limitar as aventuras (harzards) contratuais será exemplificado com o pioneirismo do consórcio conhecido por Consórcio Intermunicipal de Saúde de Penápolis - CISA, voltado especificamente ${ }^{160}$ à oferta de serviços médicos e ambulatoriais especializados. Mostraremos que, além de se garantir a qualidade do serviço público ofertado pela cooperação, um outro objetivo da coalizão é dispor dos necessários mecanismos que permitam evidenciar a credibilidade "ex-ante" do comprometimento entre os entes municipais envolvidos, principalmente, aos financiadores ${ }^{161}$ do sistema: as três esferas de governo. E, observe-se, em especial no caso da esfera municipal, que a cooperação de qualquer das elites envolvidas no

saúde pública deva corresponder um preço, já que, neste caso, o volume de oferta é determinado muito mais pelo volume de demanda estimada em razão dos custos (de produção e de transação), e não pela noção de equilíbrio de preços de mercado. Talvez, a noção mais apropriada neste contexto seja o de "mercado comum", no sentido de que ele seria criado para se reduzirem, entre os Municípios envolvidos, as barreiras aos movimentos de consumidores-eleitores que buscam tomar serviços em algum dos Municípios coligados. Esta noção de "mercado comum" sinaliza a intenção dos envolvidos em se aumentar o campo para a troca de serviços de saúde pública, muitas vezes de Municípios "privilegiados" a Municípios "latentes" a um dado custo comum; ou então, alguns Municípios "privilegiados" e "intermediários" que decidem integrar e otimizar suas respectivas produções de serviços públicos de saúde. É interessante se observar que essa noção de "mercado comum" vem de encontro a uma das referências de Adam Smith, segundo a qual, a extensão da divisão do trabalho (entendemos por cooperação por um objetivo comum) depende da dimensão do mercado.

${ }^{159}$ A justificativa de se estudarem os "riscos contratuais" advém de Williamson (1996) que afirma que "o estudo da governança está preocupado com a identificação, explicação e mitigação de todas as formas de aventuras contratuais(contratual harzards)".

${ }^{160}$ Williamson (1986) argumenta que, da mesma forma que os investimentos em técnicas especializadas são mais facilmente observados em amplos mercados do que em pequenos, pois é nos amplos que se encontra a maior probabilidade de recuperar os custos de produção; por igual razão, considerando os custos de transação, propõem que as estruturas de governança sejam também especializadas, minimizando os custos de transação, e, também facilitando a sua recuperação.

${ }^{161}$ Neste ponto convém lembrar que o ambiente institucional regrado pelo SUS apresenta algumas restrições ao financiamento às ações de saúde públicas. Algumas dessas restrições referem-se diretamente à vinculação constitucional, em cada Município, de parte de sua receita própria com os gastos destinados à política pública de saúde. Outras restrições atrelam-se aos vínculos entre as normatizações editadas pelo SUS, no que diz respeito aos parâmetros de ações de saúde a serem alcançados, com a correspondente transferência financeira aos Municípios. De qualquer forma, este assunto será mais bem esmiuçado no capítulo seguinte. 
consórcio deverá ser crível a todas as demais e continuamente expressa no recolhimento das respectivas cotas-parte.

Na transcorrer deste capítulo, e, apoiados no trabalho de Raynaud (1999), nós adaptaremos a nomenclatura utilizada por ele no desenho das relações políticas entre os Municípios. Assim sendo, consideraremos como "desenho interno" de contratos, o conjunto de cláusulas do contrato ${ }^{162}$ constitutivo da coalizão, e de "arquitetura contratual" a forma na qual as relações entre os Municípios se organizam.

Por conseqüência, o desenho de um mecanismo de coerção repousará sobre a escolha de uma arquitetura contratual para a estrutura de governança, ou seja, sobre a criação de uma pessoa jurídica, pela qual os Municípios façam uso dos serviços prestados. Neste desenho, a nova personalidade jurídica passaria então a ser o cerne da arquitetura contratual desta estrutura de governança.

E é aqui que surgem os problemas constitutivos dos consórcios intermunicipais de saúde em geral, que visam à contratação de pessoal médico especializado pelo regime CLT, a fim de remunerá-los pela produtividade segundo a lógica do mercado. Ou seja, a sua modalidade de contratação acabou diferenciando-os das demais atividades de serviço público, onde o acesso dos respectivos servidores se dá pelo regime estatutário.

Além disso, ainda nos é possível identificarmos um problema no plano político. As elites políticas municipais envolvidas no consórcio, ao tentarem "capturar" os dividendos políticos pelo fornecimento dos serviços, acabam estabelecendo disputas entre si pela ampliação dos respectivos bônus políticos e, portanto, de sua influência política nos resultados. Inclusive, nessa disputa, a elite política do Município-pólo

\footnotetext{
${ }^{162}$ Williamson (1986) identifica as características dos processos contratuais com a economia de custos de transação. São os seguintes: (a) que as modificações de uma barganha inicial dependem de quantos são os envolvidos e do quanto cada um consegue deduzir dos lances não combinados previamente; (b) que, embora as cortes de justiça que dirimam disputas contratuais de modo transparente e baixos custos, mesmo com a racionalidade limitada e com o oportunismo de cada parte interpretando as regras de modo que lhe sejam mais favoráveis, a tendência é o arbitramento, no qual, a continuidade é valorizada em relação às cortes; (c) que o fato de a justiça negligenciar a barganha e avaliar o contrato só em termos de resultado amplia a necessidade das serem auto-coercitivas, embora os envolvidos que observam as regras auto-coercitivas podem ter diferentes satisfações na barganha refletidas no contrato; (d) que o desenho contratual se revista de equidade entre os envolvidos, com igual oportunidade de participação a todos, que se contemple alguma regra para tratar das "surpresas ex-post" como exceção, e, sem provocar a
} 
pode ser vista pelas demais elites, como um "caronista" dos "bônus políticos" resultantes das ações coletivas desenvolvidas pela coalizão intermunicipal.

De qualquer forma, denota-se que quase um terço dos Municípios brasileiros estava em 1999 envolvido em algum consórcio intermunicipal de saúde. Assim sendo, os consórcios tornaram-se comuns na gestão municipal em saúde, especialmente nos Municípios de pequeno porte, em geral, os aqui denominados por "latentes", para os quais, em sua maioria, faltam os meios de diagnósticos e de atendimentos médicos especializados.

Além disso, os consórcios foram constituídos apresentando, em geral, as seguintes características: formam sociedades civis de direito privado; ampliam e ordenam a oferta de serviços em Municípios de pequeno e de médio porte, principalmente por meio de especialistas médicos e suporte para diagnóstico; compram serviços e contratam profissionais segundo regras de mercado; concentram a decisão política em Conselhos de Prefeitos; delegam a operação do sistema aos secretários de saúde da região e/ou técnicos qualificados e, em alguns casos, integram sua atuação com os Conselhos de Saúde municipais; flexibilizam a remuneração dos profissionais com pagamento de incentivos; buscam, via otimização dos recursos regionais disponíveis, melhorar o acesso e a qualidade do SUS; e, concentram as atividades de maior complexidade em um Município-pólo.

Também, como regra geral, denota-se que quase todos os consórcios se estruturaram com uma instância deliberativa máxima, o Conselho de Prefeitos. Outra característica estrutural importante, e resultante do papel de controlador social conferido pela Lei 8.080/90 que criou os Conselhos Municipais de Saúde, quase todos os consórcios incorporaram representantes desses conselhos em seus respectivos Conselhos Fiscal ou Curador.

Todas essas coalizões possuem uma instância executora técnica, denominada por burocracia da coalizão, e nomeada pelo Conselho de Prefeitos, o qual cumpre as funções tradicionais de controle e avaliação. As funções regulamentadoras são

renegociação do contrato, e, que se protejam as minorias, principalmente naqueles casos onde os efeitos da reputação são fracos, reduzindo a eficiência do controle social. 
compartilhadas com os Conselhos Municipais de Saúde. Novamente, esses fatos são anteriores à edição da NOAS 2001.

Outro aspecto relevante aos consórcios intermunicipais de saúde são as questões de acesso aos serviços, uma vez dependentes dos custos e da intensificação tecnológica. Ou seja, a regulamentação de acesso ao sistema visa combinar a qualidade e o controle de custos, voltadas ao equilíbrio de oferta e demanda, ao estabelecimento de níveis de competências e de responsabilidade no âmbito das políticas, bem como, às formas de contratação que incentivem qualidade e custo-efetividade (Klein, 1998; New e Le Grand, 1996).

\section{3. o Consórcio Intermunicipal de Saúde de Penápolis - CISA}

O Consórcio Intermunicipal de Saúde de Penápolis - CISA foi criado em 1986, portanto, antes da promulgação da Constituição Federal de 1988, com apoio financeiro do governo estadual de SP, e de uma linha de crédito no antigo BNDE. Por meio da prestação compartilhada, os Municípios envolvidos com o CISA puderam assumir a gestão autônoma em serviços especializados de saúde pública, e, isto ainda hoje representa a experiência mais duradoura de uma coalizão intermunicipal no setor.

A micro região desse consórcio situa-se no noroeste do Estado de São Paulo e a população dos sete Municípios soma 83.631 habitantes (IBGE-97). Penápolis, sede do consórcio, possui 52.433 habitantes e os demais possuem menos de 9.000 habitantes cada. A atividade econômica concentra-se na cana-de-açúcar, com um grande número de bóias frias, seguida pela pecuária extensiva.

A região é pobre e a mortalidade infantil em Penápolis diminuiu no transcurso do consórcio, de 36,8\% em 1987; para 26,4\% 1991. Segundo o IBGE-91, o analfabetismo na região é de $25 \%$, contra $22 \%$ do Estado de São Paulo. O CISA, segundo dados de 1992, possui 230 empregos médicos, distribuídos por 34 estabelecimentos, dos quais 20 em Penápolis, o que evidencia a concentração da oferta de saúde no Município-sede. 
Os sete Municípios consorciados: Alto Alegre, Avanhandava, Barbosa, Braúna, Glicério, Luziânia e Penápolis, criaram uma personalidade jurídica de direito privado, que administra os recursos e coordena as ações para a oferta de atendimento médico especializado. A ação consiste em integrar os serviços ambulatoriais básicos oferecidos ao conjunto dos consumidores-eleitores, encaminhando os pacientes aos especialistas conforme a necessidade.

Entre os Municípios que se envolveram, alguns deles não dispunham de recursos para cumprir com os requisitos normativos mínimos da NOB-93. Eram os que classificamos como Municípios "latentes", sem condições de adaptar sua estrutura autônoma de prestação de serviço público de saúde aos parâmetros exigidos para se habilitarem perante o SUS.

$\mathrm{Na}$ verdade, esses Municípios se comportavam como que indo ao "mercado fazer compras" e, como parceiros na divisão do risco da coalizão, uma vez que dispunham de parcos recursos fiscais. Com o advento da NOB-96 e a possibilidade de transferências financeiras pelo PAB a partir de 1998, todos os Municípios dessa região se mostraram incentivados a se habilitarem ao SUS, montando Conselhos, Fundos de Saúde, e outros pré-requisitos.

Talvez o incentivo mais forte à elite política do Município de Penápolis se posicionar pró-coalizão foi a redução de sua capacidade ociosa instalada de leitos hospitalares e de consultórios. Por outro lado, quando pensamos na dimensão do volume da cooperação pelo valor agregado das cotas mensais dos Municípios envolvidos, percebemos que muitas vezes esse volume pode resultar de recursos próprios, principalmente, enquanto alguns deles sequer estavam habilitados ao SUS.

E, além disso, também percebemos a real extensão das ações regionais dos consórcios, pulverizadas pelo predomínio de coalizões formadas por pequenos Municípios geograficamente próximos. E o CISA não foi diferente.

Formalmente, o CISA foi criado a partir da aprovação de lei pelas respectivas Câmaras Municipais, em 1985, autorizando os respectivos Poderes Executivos a uma coalizão intermunicipal. Em 07/86 foi realizada a assembléia de prefeitos para a constituição do CISA e aprovação de seu estatuto. A estrutura administrativa do CISA foi consagrada em 1989, com a alteração do regimento interno original. 
No entanto, em 09/92 uma resolução do Tribunal de Contas do Estado contesta $^{163}$ o caráter privado do CISA, pela qual, sendo mantido com recursos públicos, deveria atender às regras da administração pública.

Dada a intenção das elites políticas municipais de operar a sociedade como se de direito privado fosse, estas reagiram embasadas em outras experiências de consórcio entre entes públicos, com o seguinte entendimento: “(...) o questionamento jurídico do TCE-SP atinge os procedimentos (de contratação de pessoal e compra de serviços) do consórcio e não o caráter privado da sociedade civil que origina (...)” , , expresso por Carvalho e Santos (1995).

Essa reação das elites políticas envolvidas é justificada pelo objetivo de maior eficiência administrativa por meio da contratação pelo regime CLT de profissionais médicos qualificados, propondo-lhes incentivos não extensivos ao conjunto dos funcionários públicos dos Municípios envolvidos, em geral estatutários pelo Regime Jurídico Único.

Portanto, além de restrições advindas dos TCE's, gera-se um conflito, em especial no CISA, não resolvido até hoje, com um quadro de funcionários advindos de um sistema de duplo acesso: os funcionários públicos cedidos pelas prefeituras, e os funcionários contratos em regime de CLT.

Atualmente, o CISA se consolida com a seguinte estrutura hierárquica e gerencial: o Conselho de Prefeitos, que desempenha as funções do órgão decisório máximo cuja presidência é preferencialmente exercida pelo prefeito de Penápolis; a Coordenação Geral composta pela burocracia da coalizão, formada por uma estrutura de gerência dividida em uma Diretoria Administrativa e Financeira e uma Diretoria Técnica responsável pela unidade de avaliação e controle; e, a Diretoria Técnica propriamente dita, que diferentemente da burocrática, coordena os dois ambulatórios da coalizão: o de especialidades e o de saúde mental.

Quanto ao financiamento das ações especializadas de atendimento médico, com a NOB-SUS 91, o CISA passou a receber por serviços prestados segundo a

\footnotetext{
${ }^{163}$ Processo no $7489 / 026 / 92$ do TCE/SP.
} 
produção, embora a maior parcela dos custos continuava a ser coberta pelas receitas próprias dos Municípios envolvidos.

Nesse período, estimou-se que cerca de $25 \%$ dos custos eram cobertos por transferências da União e o restante pago por cotas dos Municípios envolvidos pelo critério populacional. O mecanismo era simples: do custo total era deduzido o repasse do INAMPS (forma de transferência que prevalecia até então) sendo o restante rateado entre os Municípios conforme o critério estabelecido.

A partir de outubro de 1991, o saldo de despesas passou a ser rateado entre os Municípios por outra sistemática: $50 \%$ por densidade populacional e $50 \%$ proporcionais ao uso dos serviços, de tal modo que $66 \%$ dos custos eram sustentados pelos Municípios. O restante, 13\% pelo Estado (que em 1990, financiou 84\% a título de incentivo) e $21 \%$ pela União.

Observe-se que a mudança na composição do financiamento, com maior participação dos Municípios no custeio, resulta da indução efetuada pela esfera estadual que, via convênio, financiou equipamentos, construção e a adequação física das unidades.

Evidentemente houve $\operatorname{conflitos}^{164}$, e como não poderia deixar de ser, alguns deles ocorreram na definição dos critérios de rateio das cotas dos Municípios envolvidos. Para Penápolis, Município-sede, o rateio por base populacional a onerava $^{165}$ mais em relação aos Municípios menores. Quanto a estes, consideravam as

\footnotetext{
${ }^{164}$ Conforme já exposto, os sete Municípios envolvidos se responsabilizam pelo serviço básico (via SUS), cabendo ao CISA o atendimento ambulatorial secundário e o laboratorial. No entanto, os autores Ribeiro e Costa (1999) através de questionários avaliaram a dinâmica política da coalizão, obtendo junto às elites políticas envolvidas e à burocracia da coalizão um conjunto de problemas, que se traduzem no seguinte: há conflitos de territoriedade em função de sobreposição do território coberto pelo consórcio com a estrutura regional da SES de São Paulo (o que nos remete a conceitos de federalismo); uma queda no volume de transferências financeiras do SUS induz o aumento de gastos municipais em saúde para manter a oferta de serviços por meio da coalizão (o que nos remete ao financiamento); e, que as elites políticas envolvidas devem se manter na busca por autonomia financeira do CISA e maior flexibilidade em compras e contratação (o que nos remete à reforma organizacional).

${ }^{165}$ Penápolis era o Município predominantemente exportador de serviços especializados na região, e teve ampliado o influxo de consumidores-eleitores de outros Municípios vizinhos com o incentivo à mobilidade conferido pela formação de uma coalizão intermunicipal. No entanto, o critério de rateio populacional embute conceitos autuariais uniformemente distribuídos pela região. Com isso, a relação custo incorrido com a receita repassada descompensa o sistema quando um dos Municípios envolvidos assume a maior parte dos volumes, conjugada com as diferenças sociais e de ações básicas de saúde (p.
} 
cotas, e, por extensão, os custos incorridos pelo CISA, muito altos, justificando os constantes atrasos nos repasses.

Com isso, resulta a criação de uma regra que visou assegurar o pagamento das cotas: o incondicional bloqueio das consultas aos consumidores-eleitores do Município em débito. Em 1997, indicando o predomínio dos interesses do Municípiosede, a lógica do rateio recebeu novo critério: $30 \%$ por densidade populacional e $70 \%$ pelo uso proporcional dos serviços oferecidos.

Um fato que se observou no CISA, principalmente até o advento da NOB 96, é que a idéia de parceria fica prejudicada na medida em que os demais Municípios restringem-se a "ir às compras" no Município-sede, sem colaborar diretamente na oferta aos consumidores-eleitores de um dado padrão esperado de serviços médicos especializados.

No entanto, essa assimetria ${ }^{166}$ na coalizão pode muito bem ter sido o resultado do controle administrativo e político que Penápolis sempre exerceu sobre o CISA. Um controle que se expressou por vários anos no tipo de rateio e na concentração de investimentos no Município-sede; enquanto que, por outro lado, os demais Municípios eram “incentivados” a aceitar tal predomínio em razão do acesso proporcionado aos seus consumidores-eleitores aos serviços médicos especializados, não existentes em seus Municípios.

O caso do CISA ficou ainda mais interessante quando encontramos, numa regra de direitos de propriedade ${ }^{167}$, uma possível justificativa às demais elites políticas

ex.: controle epidemiológico, saneamento básico, etc...) entre o Município-sede, exportador de serviços, e os demais da região.

${ }^{166}$ Williamson (1986) identificou, entre as possíveis características de um processo de desenho de um contrato, que quase sempre ocorrem transformações fundamentais a partir de uma barganha inicial, que dependem de quantos são os envolvidos e do quanto cada um consegue deduzir dos lances não combinados previamente. Embora, se devam incluir nessa barganha as características "ex-post", referentes à estrutura de governança que se pretende à coalizão após renegociação do contrato, se algum dos agentes puder derrubar a igualdade esperada entre os envolvidos já no processo de barganha, conseqüentemente, os lances passam a serem bi-laterais, introduzindo uma assimetria contratual entre eles. Nessa condição, a identidade das partes contratuais passa a importar, que é o que ocorreu com o CISA, inclusive com a diferenciação dos envolvidos na regra de propriedade acordada.

${ }^{167}$ As regras de direito de propriedade definem quais as possibilidades de extração de algum tipo de benefício na utilização dos ativos. Podem-se distinguir três tipos de direito de propriedade: o de usar o bem; o de auferir renda do bem; e o de transferirem direitos a ele atinentes. Os direitos de propriedade 
de sujeitarem-se a um comportamento parcimonioso. Enxergamos essa regra como resultante de um comportamento federativo de "peso e contrapeso", ou seja, ao lado da estrutura de financiamento, as elites políticas municipais adotaram um controle patrimonial difuso pela complexidade do processo político desta parceria.

Convencionou-se entre as elites políticas na constituição da coalizão, que as unidades constituídas no Município-sede, Penápolis, pertenceriam ao CISA; enquanto que as realizadas nos demais Municípios seriam de domínio dos respectivos. Ou seja, em caso de qualquer dos demais Municípios romperem com a coalizão, os investimentos do CISA ali realizados não retornam à coalizão, ficando com o Município renunciante, o que não ocorre com os investimentos efetuados em Penápolis.

De certa forma, inferimos que a elite política de Penápolis sentia-se "a cavaleiro" na presunção de que as demais dispunham de poucos recursos para a infraestrutura autônoma, enquanto, sinalizava um forte incentivo à coalizão, pretendendo, na verdade, a demanda dos demais Municípios para otimizar o dimensionamento mínimo de estruturas prestadoras de serviços de saúde pública criadas para atender os interesses de seu próprio grupo de consumidores-eleitores, haja vista a desproporcionalidade das respectivas populações.

Por outro lado, a idéia de "peso e contrapeso" dessa regra está na diminuição da capacidade de coerção da elite política do Município-sede de impor sua vontade política frente a das demais, contrabalançando sua influência na estrutura de financiamento e na gerência do CISA.

Além disso, a possibilidade de penalização patrimonial ao Município-sede o estimula a buscar um equilíbrio através de iniciativas à ampliação de sanções que dificultem a renúncia ao pacto estabelecido; embora amplie os conflitos motivados pelos atrasos nos pagamentos das cotas, reduzindo a credibilidade das sanções de suspensão do atendimento aos consumidores-eleitores do Município faltoso.

\section{4. uma interpretação econômica do CISA}

têm reflexos nos custos de transação, por exemplo, quer seja "ex-ante" na definição de seu uso fruto, quer seja "ex-post" à formação de uma coalizão, quando então há a divisão dos riscos. 
Neste ponto, procuraremos identificar os "riscos contratuais", decorrentes do funcionamento da estrutura de governança, nas relações existentes no fornecimento dos serviços especializados de saúde prestados pelo CISA, bem como, as suas implicações sobre a própria estrutura de governança.

Ou seja, identificaremos os "riscos contratuais" no fornecimento de serviços médicos especializados. Para isso, recorremos a Raynaud (1999) que utiliza alguns trabalhos sobre contratos de franchising a fim de mitigar os "riscos contratuais" de uma "marca comercial de uso em comum" criada por uma coalizão de moageiros franceses, ainda que tal enfoque apenas nos forneça uma visão parcial dos mecanismos aplicáveis aos consórcios intermunicipais, formados por pessoas de direito público.

\section{1. as implicações político-econômicas da percepção da qualidade dos serviços}

Tal qual uma marca comercial, o CISA buscaria sinalizar à população que demanda serviços médicos especializados uma qualidade no atendimento que dê suporte político eleitoral às transferências horizontais na forma de cotas de participação, e do próprio comprometimento das várias elites políticas envolvidas com a existência do consórcio municipal de saúde.

Afinal, quer seja por meio de uma marca comercial, quer seja pela imagem que o CISA oferece quanto à qualidade dos serviços, os consumidores-eleitores poderiam vincular a marca CISA com a qualidade dos serviços que essa organização oferece. Isso até parece obvio, afinal de contas, esta é a finalidade mais comum que se dá a uma marca qualquer.

Sobre essa percepção, e, com base em Matherson e Winter (1985), propomos pelo menos três fatores para explicar o desenvolvimento desses sinais: alguma mídia de comunicação de massa que reduza o custo de se estabelecer a identificação da marca CISA com a opinião sobre os serviços prestados; o aumento da mobilidade do consumidor-eleitor, que demanda em Municípios vizinhos; e um aumento na renda real 
dos consumidores-eleitores, que aumente os custos de oportunidade da procura de serviços substitutos, tais como os da iniciativa privada.

Se, a partir das considerações do capítulo anterior, adicionarmos a possibilidade de uma ampliação na renda real dos consumidores-eleitores, então, poderíamos repensar a percepção de qualidade da prestação de serviço público de saúde ofertado pelo CISA, com base na decisão pela cooperação ou não que o consumidoreleitor mediano toma, ainda que submetido a alguma promessa de campanha sobre seu consumo futuro.

Neste caso, se a expectativa de renda real futura deste consumidor-eleitor mediano foi ampliada por qualquer motivo, independente de qual seja a promessa de campanha, então poderíamos inferir que existe uma correlação direta entre o "quantum" desta expectativa de aumento futuro de sua renda real com a propensão à indiferença em sua tomada de decisão com a coalizão, de modo a se manter o "status quo". Ou seja, existindo a coalizão, tendência a mantê-la, não existindo, tendência a não votar pró-cooperação.

E, provavelmente, neste caso, poderíamos até desconsiderar os efeitos oriundos das complementariedades de outras políticas públicas sobre sua tomada de decisão. Portanto, o consumidor-eleitor mediano, sob uma regra de maioria simples, pode representar a tendência da decisão coletiva do respectivo grupo de demandantes pelo serviço ofertado pelo CISA.

De qualquer forma, não só este comportamento, mas também os demais argumentos já elencados, além de tipificarem o serviço prestado, podem sinalizar a sua qualidade (Akerlof, 1970; Klein e Leffler 1981). E, se atrelarmos essa qualidade a um dado padrão, e, se a coalizão puder mantê-lo, então, teríamos os argumentos para o estabelecimento da reputação do serviço de saúde pública ofertado, e, portanto, uma justificativa para a escolha dos consumidores-eleitores residentes na região em demandá-los da coalizão.

É interessante se observar que esta seria uma outra justificativa para a demanda dos serviços ofertados pela coalizão, ao lado da idéia de monopólio e de demanda cativa apresentada no capítulo anterior. Porém, a demanda diretamente proporcional à percepção da qualidade teria um enfoque mais especifico na 
espontaneidade das elites políticas em constituir esta coalizão, e, portanto, em sua maior responsabilidade política com a qualidade dos serviços ofertados.

Essa condição passa a ser absolutamente necessária, quando o acesso a um consórcio de prestação de serviços de saúde está disponível aos consumidores-eleitores dos Municípios envolvidos, uma vez que estes esperam encontrar o padrão de qualidade sinalizado e politicamente apregoado.

Porém, a reputação do consórcio no que se refere à qualidade de serviços médicos ofertados, sem esquecer das condições de acesso a esses serviços, é uma situação estabelecida coletivamente. Ou seja, similar ao comportamento de qualquer franqueado influenciando a reputação de uma marca comum (Tirole, 1996), o comportamento anticontratual de alguma das elites políticas municipais envolvidas no consórcio também pode influenciar na reputação da qualidade dos serviços ofertados.

Portanto, é natural que cada Município envolvido se disponha a incentivos que "encorajem" os outros a fazerem os investimentos requeridos e a manter a qualidade, se dispondo a punir algum que se esquive desse esforço e pretenda agir como "free rider" capturando dividendos políticos da reputação do grupo. Afinal de contas, não podemos nos esquecer que o voto do consumidor-eleitor, pró ou contra a cooperação estruturada como uma coalizão, pode representar o aspecto final de um processo de monitoramento da opinião pública.

Ou seja, se o fornecimento de serviços médicos especializados depende da decisão e da cooperação de vários Municípios, então qualquer comportamento oportunístico de algum deles pode ter conseqüências sobre os demais, de tal forma que as externalidades existentes "ex ante" ao pacto podem introduzir situações de dependência multilateral entre os Municípios envolvidos.

Estes problemas de oportunismo ${ }^{168}$ tomam algumas formas de acordo com as decisões normativas delegadas ao Conselho de Prefeitos e aos Conselhos de Saúde municipais. Afinal de contas, se tomarmos por base os tipos de decisões estudados na

\footnotetext{
168 Segundo Williamson (1986), os oportunismos "ex-ante" e "ex-post" são reconhecidos como seleção adversa e risco moral respectivamente. A seleção adversa seria consequiência da inabilidade de se distinguirem os riscos, e, o risco moral ocorreria quando uma das partes, devendo se comportar de modo a mitigar os riscos, não o faz. Portanto, os agentes acabam tendo diferentes comportamentos, em grau e
} 
literatura econômica sobre franchising, segundo Klein (1995), as decisões tomadas de modo descentralizado pelos Municípios tenderiam a divergir daquelas que maximizariam os resultados do CISA.

E, atrelado os resultados do CISA à qualidade percebida dos serviços médicos especializados prestados, então estamos nos referindo às decisões que afetam essa qualidade. Ou seja, se uma dada elite política municipal, independentemente das demais, pudesse impor alguma redução nos gastos incorridos nos serviços ofertados, ainda que visando a redução do valor das respectivas cotas, muito provavelmente, afetaria a qualidade dos serviços e a resposta eleitoral dos consumidores-eleitores dos demais Municípios.

Este tipo de comportamento, segundo Mathewson e Winter (1985), teria conseqüências verticais e horizontais. A horizontal viria da redução da qualidade, com o seu efeito político-eleitoral sobre todas as elites políticas envolvidas no CISA. E, a vertical viria da redução da valorização que um consumidor-eleitor atribuiria ao serviço médico especializado do CISA, diminuindo o espaço político para a manutenção do consórcio.

Também prejudicam a maximização do resultado do CISA, aquelas decisões que facilitam a ação de Municípios “caronistas”, ou mesmo, de assumirem um comportamento de "risco moral". Um exemplo poderiam ser as possíveis pressões políticas exercidas sobre o Conselho de Prefeitos, a partir de algum Conselho de Saúde Municipal influente pelo fornecimento de serviços a algum Município não envolvido com a coalizão, ou, se envolvido, com suas cotas em atraso.

Um outro exemplo poderia se vincular ao CISA, onde alguma das elites políticas municipais envolvidas nesta coalizão, a fim de usufruir a norma sobre o controle patrimonial, buscasse direcionar o orçamento do consórcio para a realização de investimentos ociosos em sua jurisdição. E, isso sem falar que conluios podem ocorrer entre algumas elites políticas envolvidas na coalizão, como um tipo de comportamento oportunístico voltado às sub-coalizões.

tipo, o que ocasiona custos "ex-ante" na revelação desses comportamentos, e "ex-post", no monitoramento. 
De qualquer forma, os serviços médicos ofertados pelo CISA pretendem-se de qualidade, e a redução dessa qualidade terá conseqüências sobre o status políticoeleitoral de suas elites políticas, e, sobre o consumo final desses serviços, com tendência à redução da demanda por serviços ofertados sob o nome CISA.

Para realçar a influência política da qualidade dos serviços prestados pelo consórcio, observe-se que estas coalizões podem não sobreviver se os consumidoreseleitores capturarem de um outro Município próximo à região, que não faça parte da coalizão, resultados de qualidade ${ }^{169}$ superior, obtidos com os mesmos volumes de investimento e gastos incorridos pela coalizão, e na condição de que a mobilidade dos consumidores-eleitores é suficiente e o acesso deles à opção de serviço seja irrestrito.

Já o estudo da estrutura de governança de um consórcio de serviços médicos especializados pode também se basear no princípio da externalidade proposta por Williamson (1981), pelo qual "o pressuposto normal de que a troca entre produtores de bens diferenciados ${ }^{170}$ (...), é progressivamente enfraquecida quando a demanda de externalidades aumenta (...) quando os efeitos da interação da demanda se tornam mais importantes".

Observe-se que o consórcio mantém a autonomia das elites políticas municipais, embora estas fiquem na expectativa dos incentivos proporcionados pelos bônus políticos. Ou seja, os bônus são resultados residuais expressos em número de votos, sujeitos às decisões referentes à postura pró ou contra cooperação dos vários grupos jurisdicionais de consumidores-eleitores na região, desde que aquelas decisões

\footnotetext{
169 Além disso, "cetirus paribus", estamos considerando a qualidade ofertada do serviço público como a única variável explicativa da tomada de decisão do consumidor-eleitor por demandar, ou não, serviços especializados do consórcio. As demais variáveis consideradas nos capítulos anteriores, por facilidade construtiva, serão consideradas dadas, em especial, aquelas que se vinculam a considerações tributárias. Ou seja, estamos considerando inalteradas as questões vinculadas à guerra fiscal, tais como o efeito que teria sobre a decisão dos consumidores-eleitores de demandar ou não os serviços especializados do consórcio se lhes fosse, por exemplo, divulgado que um Município próximo à região da coalizão empreendeu um esforço de fornecer o mesmo serviço a um "preço" mais baixo, ou seja, a um tributo "per capita" de alíquota menor. Considerações desse tipo envolvem conclusões multifacetadas, ou seja, a coalizão poderia retaliar com uma política de alíquotas tributárias agressiva, que dependeria das condições de se incentivarem todas as suas elites políticas a tomar decisão na mesma direção, e isso sem mencionar as conseqüências sobre a complementariedade dessa medida com outras políticas públicas. Além disso, será que esse Município próximo tem real interesse em reduzir suas alíquotas e correr o risco de tornar deficitário no serviço prestado? Será que a mobilidade necessariamente alta para que a guerra fiscal tenha efeitos não é suficiente para também induzir as elites políticas envolvidas na coalizão a reduzir suas alíquotas tributárias, ou mesmo, sustentá-las, e tornarem-se superavitários?
} 
estejam coladas às decisões individuais das elites políticas correspondentes e também se refiram às preferências reveladas pró ou contra a cooperação.

Porém, quando nos referimos a quaisquer outros incentivos, que não os referentes aos bônus políticos na forma de votos, segundo Brickley e Dark (1987), estes poderiam conduzir à sub otimização do serviço prestado pois, como já vimos, os "riscos contratuais" são uma possibilidade dentro da racionalidade econômica, e devem ser analisados.

A questão então se volta ao monitoramento das elites políticas, pois no caso de uma coalizão como o CISA, a demanda de seus serviços é realizada por consumidores-eleitores de vários Municípios, e, tal qual na situação de franchising, torna-se bastante difuso o monitoramento a partir unicamente de cada consumidoreleitor. Portanto, faz-se necessário que este monitoramento se dê por meio de representantes dos consumidores-eleitores, como já abordado no capítulo anterior.

Porém, desconsiderando a necessária existência dos Conselhos de Saúde, nos lembremos de que o CISA está inserido num mercado de serviços médicos, de estrutura corporativista, a qual introduz um controle adicional ao comportamento das elites políticas municipais, e que repercute na formação de opinião e na tomada de decisão dos respectivos consumidores-eleitores. Por esta razão, poderíamos inserir as ações desta estrutura corporativista entre aquelas de controle social das políticas públicas.

Este controle pode ser direto sob a forma de monitoramento do comportamento das elites políticas, em especial, o recolhimento de suas cotas, ou pode ser indireto, como na forma, por exemplo, de restrições aos direitos de decisão técniconormativa dentro da coalizão. Em suma, há várias formas de os grupos de consumidores-eleitores exercerem seu direito ao controle social da política pública de saúde na região abrangida pela coalizão.

A literatura econômica sobre franchising, em especial Lafontaine (1992), Klein (1995) e Rubin (1978), entre outros, foca os atributos contratuais de uma estrutura de governança, tratando das cláusulas contratuais que permitem incentivos aos franqueados e/ou franqueador. Transportando esta postura para a coalizão

${ }^{170}$ Aqui incluímos a prestação de serviço. 
intermunicipal CISA, poderíamos tentar explicar a motivação das elites políticas com a coalizão a partir dos modelos de agência encontrados em Bhattacharyya e Lafontaine (1995), Lafontaine (1992) e Rubin (1978). Como esses modelos enfatizam a divisão de lucros como o principal mecanismo de incentivo para as partes contratuais, os adaptaremos a este estudo, entendendo a divisão de lucros como a divisão de bônus políticos, na forma de votos eleitorais.

Embora esse bônus seja difícil de ser alocado entre as elites políticas, ainda que expresso em número de votos, pretende-se com esta adaptação, correlacionar a divisão de bônus político, por meio do resultado político-eleitoral do consórcio, na medida em que os consumidores-eleitores percebam a qualidade dos serviços prestados, e o quanto afeta a possibilidade de acesso a esses serviços em suas funções utilidade.

Ou seja, proporcionalmente ao sucesso da coalizão, as elites políticas, com objetivo no resultado político-eleitoral, procurariam vincular a sua participação nas tomadas de decisão referentes à coalizão, com a responsabilidade pela qualidade percebida dos serviços demandados pelos consumidores-eleitores de suas respectivas jurisdições.

Porém, a partir de uma outra corrente da literatura, Klein (1995) estuda as cláusulas contratuais como uma forma de facilitar os mecanismos autocoercitivos, visando, inclusive, a redução de custos de monitoramento. Para isso, propõe como necessários três elementos, os quais, adaptamos à coalizão na seguinte conformidade: a relação ${ }^{171}$ entre a burocracia do consórcio e as elites políticas municipais devem criar a expectativa de uma "corrente de prêmios" no futuro, ou seja, de bônus políticos (rendas); a burocracia do consórcio (franqueador) deve ter o direito de monitorar o comportamento das elites políticas envolvidas (franqueados); e, a burocracia do consórcio (franqueador) deve ter a possibilidade de terminar facilmente a relação, até como ameaça de punição. Quando estas três condições estão garantidas, a perda de futuros bônus político-eleitorais representa uma ameaça crível.

Seguindo e adaptando a formalidade de Raynaud (1999), seja $\mathbf{B}^{\mathbf{1}}$ o valor presente descontado dos bônus políticos, podendo ser expresso em participação no

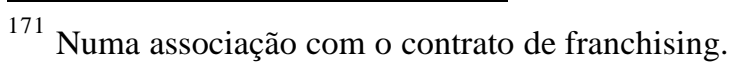


volume de votos que uma elite política municipal possa ganhar trapaceando ${ }^{172}$; e seja $\mathbf{B}^{2}$ o valor presente descontado da corrente de prêmios (bônus político) que uma dada elite política municipal possa ganhar agindo conforme as normas de funcionamento do consórcio. Então esse contrato será autocoercitivo para toda aquela elite política municipal que tenha $\mathbf{B}^{\mathbf{2}} \geq \mathbf{B}^{\mathbf{1}}$, ou seja, na situação em que vale a pena cooperar.

Portanto, tal qual um franqueador em Klein e Saft (1985), um consórcio escolherá monitorar intensamente a qualidade de seus serviços prestados, de modo que a corrente de prêmios futuros, expressa pelos bônus políticos, minimize os seus custos de policiamento "ex-post" sobre os compromissos dos componentes da coalizão, e reduzindo os ganhos de um comportamento oportunístico.

Com isso, o contrato de prestação de serviços médicos aos Municípios envolvidos deveria conter mecanismos autocoercitivos, tais como a previsão de um sistema que restrinja o direito de acesso aos consumidores-eleitores do Município que se omita do pagamento de sua cota; ou ainda, estabelecer restrições à tomada de decisões normativas no âmbito da coalizão ${ }^{173}$.

Há outras cláusulas que também poderiam ampliar os custos de um comportamento oportunístico, reduzindo os bônus políticos; a noção de um território exclusivo, embutida em uma normatização da prestação de serviços médicos especializados dirigida apenas aos Municípios envolvidos na coalizão. Segundo Klein (1995), existem, no caso de franchising, dois tipos de aprovisionamento de territórios exclusivos: o completo e o compartilhado. No caso do CISA, este possuiria o monopólio territorial da prestação de serviços médicos especializados, de caráter público e patrocinados pelos entes federativos envolvidos.

Porém, como já mencionado, a norma sobre a destinação patrimonial, em caso de algum Município se separar do CISA, pode estimular comportamentos oportunísticos em uma dada elite política municipal que decida, isoladamente, oferecer serviços semelhantes, em parte ou no todo, visando maximizar seu resultado eleitoral, absorvendo o total dos bônus políticos de sua jurisdição.

\footnotetext{
${ }_{173}^{172}$ Por exemplo, essa elite política pode agir de modo a evitar pagar sua cota no consórcio.

${ }^{173}$ No entanto, o mecanismo de se estabelecerem restrições à tomada de decisões normativas no âmbito da coalizão, não é encontrado no trabalho de Ribeiro e Costa (1999) como tendo sido aplicado ao CISA.
} 
Por outro lado, esse procedimento oportunístico também pode incorrer em custos muito altos ${ }^{174}$, a ponto de comprometer os bônus políticos futuros. E, quanto mais crível essa ameaça, maior o incentivo em não se comportar oportunisticamente.

\section{2. estruturando a cooperação na forma de uma coalizão (consórcio)}

Quase todos os trabalhos sobre o desenho de contratos de franchising focam sobre a relação bilateral entre um franqueado e um franqueador. E, em geral, quando formam uma rede, a tratam pela soma de várias relações bilaterais.

Diferentemente desse enfoque, Raynaud (1999) buscou a visão do mecanismo de governança instalado em uma rede onde os franqueados possuem o franqueador, de tal sorte que os franqueados, coletivamente, possuem os direitos residuais de controle sobre os ativos do franqueador, conforme Grossman e Hart (1986).

A diferença observada com o nosso tema é que o CISA, enquanto prestador de serviços, detém o usufruto da propriedade dos bens públicos colocados a sua disposição pelas elites políticas no seu ato constitutivo. Por outro lado, os investimentos em infraestrutura voltados a atender as necessidades da coalizão durante a sua existência, se realizados no Município-sede, seriam de domínio e uso-fruto da coalizão. Porém, se realizados em qualquer dos outros Municípios, a coalizão teria o usufruto, ficando o domínio para a jurisdição onde foram realizados.

Evidentemente, esta regra de propriedade, atrelada ao fato de que lidamos com bens públicos e não bens privados, como no caso dos contratos de franchising, trás alguns problemas na adaptação dessa literatura ao caso de uma coalizão intermunicipal. E, assim sendo, infere-se ao CISA uma natureza dupla.

Com relação à prestação de serviços médicos especializados, sua ação seria similar a qualquer empreendimento padrão com sua atividade voltada a um 
determinado grupo de "compradores" de seus serviços: as elites políticas dos Municípios envolvidos. Enquanto isso, pelo enfoque dos "proprietários" do CISA, este consórcio de serviços médicos se assemelharia a uma cooperativa criada pelos Municípios envolvidos.

Como resultado, há uma dupla relação de delegação de tomada de decisão: da burocracia do consórcio às elites políticas municipais pelo direito de acesso aos serviços médicos especializados oferecidos; e, dos proprietários do consórcio (os Municípios envolvidos) ao consórcio (cuja Diretoria é escolhida pelo Conselho de Prefeitos).

Assim sendo, a construção organizacional do consórcio surge com as elites políticas envolvidas assinando um contrato pelo direito de acesso de seus respectivos consumidores-eleitores aos serviços médicos oferecidos, e os consumidores-eleitores desses Municípios envolvidos passam a usar desses serviços como se fossem um agente que não o possuí, ao menos do ponto de vista econômico.

O interessante aqui é que, além de esta análise se ambientar no setor de saúde pública, esta coalizão de prestação de serviço médico especializado é organizada de modo que os seus proprietários são os exclusivos beneficiários. Segundo Raynaund (1999), "na linguagem do modelo agente-principal ${ }^{175}$, o Principal não pré existe antes da relação entre os Agentes, mas é criado por eles. Isto mostra que a escolha de governança não pode ser reduzida à determinação das cláusulas contratuais; pois o franqueador (consórcio) não pré existe antes da relação entre os vários membros da rede mas resulta da construção deliberada ".

\footnotetext{
${ }^{174}$ Por exemplo, essa elite política, ao visar gastar menos do que a cota que era paga ao consórcio, acaba oferecendo serviços cuja qualidade pela percepção de seus consumidores-eleitores é mais baixa da que era oferecida pelo consórcio.

Segundo Eggertsson (1996), a teoria da agência é um ramo da economia dos custos de transação estabelecida quando um principal delega direitos a um agente, por exemplo, direitos de uso de uma fonte de recursos. Isso significa que o agente estará limitado por um contrato, que pode ser formal ou informal, com a função de representar os interesses do principal em troca de algum tipo de pagamento. Dentro dessa teoria estão embutidos conceitos como comportamento oportunístico, seleção adversa e de risco moral. As informações que compõem o contrato estão distribuídas entre os personagens envolvidos de modo assimétrico. Em geral, o agente tem certa vantagem sobre o principal, pois este tem custos em obter informações sobre os agentes no que diga respeito às suas características e performances, podendo os agentes agravar esses custos agindo de modo oportunístico na medida em que o principal tenha interesse em um contrato que reduza seus custos de agência, e tenha que desenvolver mecanismos de
} 
Portanto, para explicar a criação do CISA, retornemos à situação na qual esse consórcio ainda não exista. Nesse caso, o sistema de saúde na região era composto apenas pelas estruturas municipais autônomas, ou seja, de cada Município. E, embora em 1986 ainda não existisse o SUS, admitiremos que cada Município envolvido neste consórcio procurava adequar a sua prestação de serviço público de saúde às normas do sistema SUS.

Neste cenário, admitiremos a existência de externalidades ${ }^{176}$ entre os Municípios da região, a qual afetaria, principalmente, o Município de Penápolis dada sua capacidade ociosa em leitos hospitalares e sua alta concentração de serviços médicos. Cria-se, então, uma situação de dependência multilateral entre os Municípios da região, onde os resultados de um agente em absorver externalidades dependem do comportamento dos demais. E, portanto, se desenvolve um ambiente onde as decisões individuais de cada Município não maximizam o total do excedente dessas relações.

\section{3. as elites políticas realizando seus resultados}

Uma possível solução seria o rateio dos custos através de um contrato (convênio/convênio) entre os Municípios que forneça os incentivos apropriados. Tratase de uma solução considerada ineficiente por Alchian e Demsetz (1972) e cuja prova formal foi dada por Hölmstrom (1982), pela qual demonstra que, mesmo em um modelo Agente-Principal com múltiplos agentes, uma solução contratual não é suficiente para restaurar a eficiência.

Assim sendo, Raynaud (1999) desenha uma rede franchising, baseada na demonstração formal de Hölmstrom (1999), supondo que há $\mathbf{n}$ agentes neutros ao risco em um time que é organizado assim que seus insumos produtivos são relacionados a

monitoramento dos agentes. Entretanto, o alto custo em se avaliar a performance e o comportamento dos agentes, e de atribuir confiança a essa medição, pode levar à seleção adversa e ao risco moral.

Evidentemente, algumas outras variáveis poderiam ser consideradas tais como, as políticas de alíquotas tributárias praticadas, os graus de mobilidade, as diferenças sociais entre os Municípios envolvidos, o padrão e o volume de oferta dos serviços públicos, etc... 
um objetivo comum esperado. Nesse time, cada agente i escolhe um esforço não observável ai que representa o custo privado do esforço.

Adaptando as considerações de Raynaud (1999) ao CISA, podemos considerar que o agente que $\mathbf{n}$ representa seja uma dada elite política municipal, considerando que todas elas seriam neutras ao risco. Essa elite política estaria envolvida em uma coalizão (adaptando o conceito de "time" em Hölmstrom (1982)) organizada para o aproveitamento em comum de seus insumos produtivos à prestação de serviços públicos de medicina especializada.

Se cada uma dessas elites políticas municipais está disposta a um esforço não observável ai, então, a variável ai representaria o custo privado do esforço de uma dada elite política municipal i em pagar a sua cota. Portanto, a variável ai pode também ser vista como o custo de se ofertar (ou comprar do consórcio) um serviço médico especializado a um padrão de qualidade compromissado pela elite política aos seus respectivos consumidores-eleitores em promessa de campanha.

$$
\begin{gathered}
\mathbf{a i} \in \mathbf{A i}=\{0, \infty\} \\
\mathbf{a}=(\mathbf{a} 1, \mathbf{a} 2, \ldots, \text { ai }, \ldots, \text { an }) \in \mathbf{A} \equiv \mathbf{X}(\mathbf{n}, \mathbf{i}=\mathbf{1}) . \mathbf{A i}
\end{gathered}
$$

As ações da coalizão a todos os consumidores-eleitores da região produzem um resultado regional agregado $\mathbf{x}=\mathbf{x}(\mathbf{a 1}, \ldots$, an). Essa função pode correlacionar os vários esforços individuais com o volume agregado de acessos dos diversos consumidores-eleitores ao serviço médico especializado. Assume-se que x(.) é diferenciável e estritamente côncava com $\mathbf{x}(\mathbf{0})=\mathbf{0}$.

Seja $\mathbf{s i}(\mathbf{x}) \geq \mathbf{0}, \mathbf{i}=\mathbf{1}, . . ., \mathbf{n}$ a cota-parte do bônus político do agente $\mathbf{i}$. Seja também assumido que o bônus político é completamente distribuído entre os agentes (as elites políticas municipais envolvidas na coalizão), isto é, para $\mathbf{i}=\mathbf{1}, \ldots, \mathbf{n}$ tem-se que:

$$
\Sigma \mathbf{s i}(\mathbf{x})=\mathbf{x}, \forall \mathbf{x},(\text { eq. } 1)
$$


O vetor eficiência de ações $\mathbf{a}^{*}$ é encontrado pela maximização do excedente total, tal que, para $\mathbf{i}=\mathbf{1}, \ldots, \mathbf{n}$ tem-se:

$$
\mathbf{a}^{*}=\operatorname{argmáx}\left\{\mathbf{x}(\mathbf{a})-\sum \mathbf{a i}\right\},(\text { eq. } 2)
$$

Sob as suposições anteriores sobre $\mathbf{x}(\mathbf{a})$, as seguintes condições de primeira ordem caracterizam amplamente a solução ótima $\mathbf{a}^{*}$ :

$$
\left(\partial \mathbf{x}\left(\mathbf{a}^{*}\right) / \partial \mathbf{a i}\right)-\mathbf{1}=\mathbf{0}, \text { para todo } \mathbf{i}=\mathbf{1}, \ldots, \mathbf{n},(\text { eq. } 3)
$$

Desde que insumos à prestação de serviços de saúde pública são escolhidos privativamente por cada elite política municipal, alguma delas pode assumir uma escolha não cooperativa de $\mathbf{a} * \mathbf{i}$. Se assumirmos que as regras de divisão dos bônus políticos são diferenciáveis, nós temos as seguintes condições de primeira ordem para um equilíbrio de Nash a+:

$$
\{\mathbf{d s i}(\mathbf{x}(\mathbf{a}+)) / \mathbf{d} \mathbf{x}\} .\{\partial \mathbf{x}(\mathbf{a}+) / \partial \mathbf{a i}\}-\mathbf{1}=\mathbf{0}, \text { para todo } \mathbf{i}=\mathbf{1}, \ldots, \mathbf{n}, \text { (eq. } 4)
$$

Comparando (3) e (4), nós vemos que se quisermos que $\mathbf{a}^{*}=\mathbf{a}+$, nós devemos ter:

$$
\mathbf{d s i}\left(\mathbf{x}\left(\mathbf{a}^{*}\right)\right) / \mathbf{d x}=\mathbf{1} \text { para todo } \mathbf{i}=\mathbf{1}, \ldots, \mathbf{n},(\text { eq. } 5)
$$

Se diferenciarmos a restrição política (em Raynaud (1999), orçamentária), nós temos para todo $\mathbf{i}=\mathbf{1}, \ldots, \mathbf{n}$ :

$$
\sum\left(\mathbf{d s i}\left(\mathbf{x}\left(\mathbf{a}^{*}\right)\right) / \mathbf{d a}\right)=\mathbf{1}(\text { eq. } 6)
$$


Como as equações (5) e (6) são inconsistentes, o equilíbrio de Nash não é um ótimo de Pareto. Raynaud (1999) esclarece que este "resultado se sustenta seja qual for o desenho de contrato de divisão ". Ou seja, demonstra-se que uma solução contratual para a repartição do resultado global expresso em bônus político não incentiva a maximização desse excedente global.

Se a organização desenhada para "governar" o fornecimento de serviços médicos especializados é reduzida a acordos para a divisão dos resultados políticos, ou, a um conjunto de contratos de divisão bilaterais entre as elites políticas municipais envolvidas, então, algumas das externalidades permanecerão (Raynaud, 1999).

A solução de Alchian e Demsetz (1972) deste problema entre agentes é "trazer" um principal que monitore os componentes da coalizão ("time"). Para monitorar o comportamento individual, o monitor (a burocracia do consórcio) pode limitar o comportamento individual da elite política municipal, ofertando o serviço público a cada agente, de acordo com a sua contribuição.

Para Hölmstrom, o problema do "caronista" é conseqüência do não monitoramento das ações individuais, como também da imposição de um equilíbrio político (em Raynaud (1999), orçamentário).

Segundo Raynaud (1999), se esta última restrição é afrouxada, ou seja, se a equação (1) fosse $\sum \mathbf{s i}(\mathbf{x})$ x (a agregação do bônus político dividido entre todos os agentes fosse menor ou igual ao resultado global), o vetor ótimo de decisões $\mathbf{a}^{*}$ seria então um equilíbrio de Nash, pois todos os Municípios envolvidos, na pessoa de suas elites políticas, estariam satisfeitos com a sua participação na distribuição dos bônus políticos.

Ou seja, os agentes vão dividir o resultado ótimo $\mathbf{a}^{*}$ se o resultado global a é superior ou igual ao resultado ótimo $\mathbf{a}^{*}$, e nada recebem se o resultado é mais baixo daquele ótimo. Assim sendo, relaxar a restrição política permite a criação de penalidades coletivas suficientes ou dá os incentivos certos aos agentes, podendo neutralizar as externalidades na oferta de serviços de saúde pública.

Todavia, se as penalidades são auto impostas pelas elites políticas municipais, muito provavelmente terão em algum momento problemas de auto-coercitividade, até por que as elites políticas municipais não têm interesse em se desgastar politicamente, 
podendo haver a formação de um "espírito de corpo" tolhendo as punições, ou mesmo, a formação de conluio dentro da coalizão.

Além disso, ao invés de nada receber, as elites políticas dos Municípios sempre terão um interesse em dividir um resultado sub-ótimo, ao invés de correrem o risco de terem que se submeter às penalidades auto impostas.

Portanto, neste caso, poderá se fazer necessária a renegociação do contrato da coalizão para se resolver este problema de credibilidade. Provavelmente se fará também necessária a participação de algum terceiro como mediador que, na posição de um principal, implemente um esquema de incentivos aos agentes (elites políticas municipais envolvidas) que se vincule à qualidade dos serviços e ao grau de acesso percebido pelos consumidores-eleitores, sinalizando, portanto, aos vários grupos de consumidores-eleitores, o rateio do bônus político a ser realizado, e, dessa forma, a ameaça de serem penalizados com o fato de a não re-eleição tornar-se crível.

Hölmstrom (1982) também mostra que a implementação de contratos de incentivos supõe a criação de um Principal. Concluí-se, portanto, que para o desenho de um contrato preocupado com a eficiência, deve-se pensar na estrutura de governança. No caso do CISA, se expressa com os Agentes (as elites políticas municipais envolvidas numa coalizão regional) criando um Principal (o consórcio) para forçar um sistema de prêmios.

No entanto, qual seria a lógica econômica por trás da criação de um Principal híbrido, como resultado da credibilidade nos compromissos acordados entre alguns Agentes? Raynaud (1999), para responder a essa questão sob a ótica do franchising, cita Williamson (1983), que parte da situação na qual um empreendedor cria um produto (uma idéia original), vende a patente a um grupo de firmas geograficamente dispersas, mas com territórios exclusivos. Os clientes desse grupo têm plena mobilidade e se baseiam na reputação da rede (franchising). As externalidades horizontais que ocorrerem entre as firmas devem ser compensadas (punidas) por elas mesmas, o que é ineficiente.

Logo, segundo Williamson (1983): “Os franqueados sob um cenário revisado criam um agente para policiar a qualidade ou de outro modo imaginar penalidades que dissuadam a deterioração da qualidade. Uma possibilidade é retornar ao 
empreendedor e contratá-lo para providenciar tais serviços. Servindo agora como um agente de franqueados, o empreendedor pode empreender um programa de checagem de qualidade(...)” (p. 350).

O paradoxo desta estrutura é que um "administrador", o consórcio, tenha de monitorar o comportamento de seus "patrões", os Municípios envolvidos. Além do mais, citando Sappington (1991), "um contrato de incentivos deve incluir o controle de direitos residuais, especificando qual parte terá a autoridade de tomar decisões críticas quando contingências não especificadas previamente ou imprevistas surgirem (...) a avaliação de tais direitos podem ter importantes implicações para a performance e o valor dos relacionamentos "

\section{5. a arquitetura contratual da estrutura de governança do CISA}

\section{1. uma estrutura de governança que proteja a reputação da qualidade dos serviços}

Segundo Raynaud (1999), trabalhos como os de Alchian e Demsetz (1972), Hölmstrom (1982) e Williamson (1983) sugerem que a criação de uma pessoa jurídica amplia a credibilidade dos compromissos assumidos pelos agentes no momento da constituição. No nosso caso, aplica-se à decisão de elites políticas municipais para a estruturação da cooperação na forma de um consórcio, por meio do qual elas objetivam dividir os resultados político-eleitorais do fornecimento de serviços médicos especializados.

No entanto, enquanto Alchian e Demsetz (1972), e Williamson (1983), enfatizam o controle do comportamento individual, Hölmstrom (1982) defende a presença de uma pessoa jurídica como monitora dos comportamentos individuais para controlar os oportunismos que constam da função objetivo dos agentes envolvidos. Em complemento, Raynaud (1999) utiliza alguns trabalhos sobre franchising, em particular os de Klein (1995) e de Klein e Murphy (1988), para mostrar que só o controle não 
limita o comportamento "free rider" de franqueados individuais, pois, a cada regra de controle dever-se-ia corresponder uma penalidade, ou seja, os contratos devem prever mecanismos de coerção.

Seguindo a nomenclatura proposta por Raynaud (1999), chamaremos de "estrutura interna de um contrato" ou "arquitetura interna", o desenho das várias cláusulas. E, conhecida a arquitetura interna, chamaremos de "arquitetura contratual" de uma estrutura de governança multilateral ao modo pelo qual o conjunto de contratos bilaterais entre os agentes é organizado.

Ao estudarmos o CISA como uma estrutura multilateral, encontramos uma pessoa jurídica na forma do consórcio propriamente dito, que é parte central nas relações contratuais com todos os Municípios envolvidos. Nesta arquitetura, os vários Municípios envolvidos são também proprietários do consórcio. Observe-se que ser a parte central nas relações contratuais é uma necessidade para o exercício eficiente de mecanismos de coerção, onde o Principal, a fim de implementá-los, deveria realizar um contrato com cada Agente.

Essa arquitetura contratual com uma pessoa central, a seguir representada, se contrapõe à arquitetura de uma administração "mais descentralizada" das externalidades. Seguem-se, portanto, duas figuras representando diferentes arquiteturas contratuais para a governança de um serviço público de medicina especializada.

Figura I: Possíveis arquiteturas contratuais
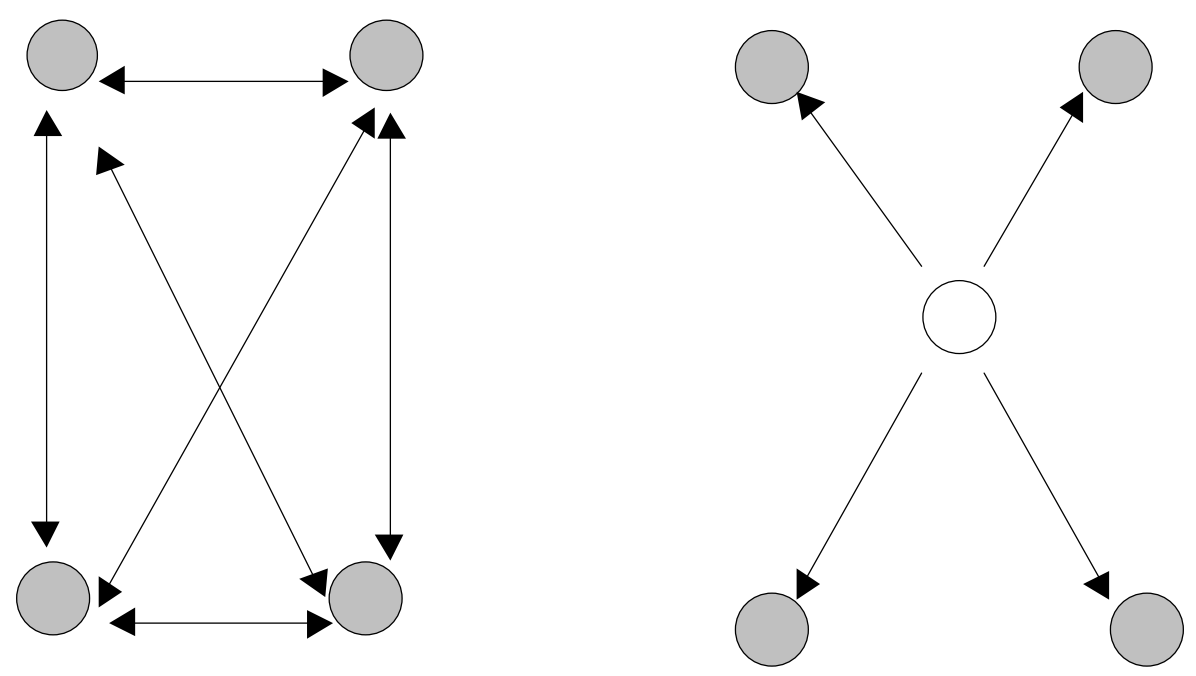
Sem uma Pessoa Central
Com uma Pessoa Central

A partir desses esquemas, percebe-se que esta arquitetura, com uma pessoa jurídica central (o consórcio), permite a redução do número de contratos quando comparada à outra arquitetura, reduzindo os custos de transação ${ }^{177}$. Entretanto, além de a redução do número de contratos poder justificar a existência de uma pessoa central (o consórcio), permite-se um melhor desenho de mecanismos de coerção.

No modelo de Hölmstrom (1982) adaptado na seção anterior, o principal, sem exercer monitoramento, possuí um mecanismo de coerção apoiado exclusivamente em penalidades críveis. No caso de uma coalizão de Municípios, como já observado no capítulo anterior, a ausência de monitoramento na forma de controle social exercido por representantes dos consumidores-eleitores conduz a resultados ineficientes na medida em que a aplicação de penalidades pelo principal (a coalizão) a um agente (pessoa jurídica de direito público) pode não ser crível, ou seja, tende a não ser "autocoercitiva".

Já nos contratos de franchising, cada franqueador monitora ativamente os seus franqueados, seja pelo acesso a suas performances, seja para poder se assegurar de que não falhe com seus compromissos, por exemplo, por meio de inspeções regulares sob a qualidade de produtos e serviços.

\footnotetext{
177 Emprestamos de Eggerttsson (1996) a seguinte definição de custos de transação: surgem quando os indivíduos trocam direitos de propriedade por ativos econômicos e procuram fazer cumprir seus direitos exclusivos. Os custos de transação ocorrem por falta de informação plena e porque a sua obtenção é custosa. Eles têm vários tipos de custos, mas, nenhum deles relacionados aos custos de produção ou de comercialização. Como exemplo, têm-se primeiramente os custos "ex-ante" : a busca de informações sobre custo e qualidade dos serviços prestados e sobre o comportamento dos demais personagens envolvidos; a barganha política para encontrar o equilíbrio de produção e custos; o desenho do contrato constituinte da coalizão. Com relação aos custos "ex-post" teríamos: o monitoramento dos personagens envolvidos em relação às condições do contrato; a divisão do risco ocorrido, ou seja, do prejuízo eventualmente causado por um comportamento oportunístico de algum dos envolvidos; ou a proteção dos direitos de propriedade contra terceiros.
} 
Ainda com relação à literatura aplicada à franchising, tem-se que o controle de comportamento oportunístico do franqueado, embora uma condição necessária, não era suficiente. Ou seja, além de se garantir que o valor monetário da sanção seja alto o bastante para limitar o comportamento oportunístico, são também necessários outros dois elementos já vistos anteriormente: a criação de uma corrente de prêmios e a possibilidade de exclusão, ainda que temporária, como no caso de agentes pessoas de direito público.

No caso do CISA, estes três elementos poderiam aparecer da seguinte forma: suponhamos que a burocracia do consórcio monitore ativamente as elites políticas dos Municípios envolvidos a baixos custos e sem transferir-lhes qualquer resultado político “ex-post". Se uma determinada elite política municipal for excluída ${ }^{178}$ da coalizão, ela não tem qualquer custo, na medida em que, no limite, ela nada tenha a perder com sua saída. Portanto, a ameaça de exclusão, como um incentivo negativo, seria não crível.

Agora, admitamos um outro cenário, em que as elites políticas municipais envolvidas ganhem uma quantidade positiva de bônus político-eleitorais pela associação que os consumidores-eleitores fazem de suas ações voltadas à coalizão com a qualidade dos serviços prestados pelo consórcio, e que a burocracia do consórcio as monitora ativamente, mas sem uma regra de exclusão, ou, que a sua aplicação seja problemática ou muito custosa. Também aqui a ameaça de perda de rendimentos políticos é limitada, pois as elites políticas municipais (que também tomam as decisões em nome dos proprietários do consórcio) sabem que esta ameaça é custosa para a burocracia do consórcio (afinal, monitorar os "patrões" quase sempre amplia o risco de perderem seus cargos).

No entanto, desenhada esta situação, mas com a presença dos três elementos acima relacionados, a ameaça pode torna-se crível, desde que o custo de término do CISA passe a ser maior para essas elites políticas.

Assim sendo, justifica-se a escolha da arquitetura contratual em que uma pessoa jurídica faça o papel central do relacionamento. Essa pessoa central, o consórcio, assume o papel de "ofertante de direito" dos serviços de medicina

\footnotetext{
${ }^{178}$ Note-se que o trabalho de Ribeiro e Costa (1999) nada fala a respeito de regra de exclusão de agentes do sistema, apenas de regras de suspensão de direitos, na estrutura desenhado para o CISA.
} 
especializada, enquanto os "ofertantes de fato", as elites políticas municipais, concedem-lhe o direito usual de quem oferta tal tipo de serviço público.

Assim sendo, e apoiados no mecanismo de coerção estudado por Klein, podemos identificar dois elementos no CISA que criam uma corrente de prêmios futuros às elites políticas envolvidas: a qualidade dos serviços prestados que é capturada pelos consumidores-eleitores, e repassada às elites políticas municipais por meio do voto; e, o aspecto territorial do CISA, que reduz a competição tributária entre os Municípios, com a absorção de externalidades.

\section{2. uma estrutura de governança eficiente que mitigue os "riscos contratuais"}

Para responder esta questão, é necessário retornar à cláusula contratual que atribui ao CISA o provisionamento exclusivo do serviço público de prestação de saúde aos Municípios envolvidos. Ou seja, admitimos a existência de uma cláusula de exclusividade territorial na prestação de serviços públicos de saúde à região; inexistindo, portanto, quaisquer outros sistemas autônomos municipais de saúde pública.

Porém, esta hipótese não exclui a possibilidade dos sistemas privados, afinal a opção pela coalizão é uma decisão da maioria dos consumidores-eleitores de um determinado grupo. Dessa forma, se a regra de tomada de decisão coletiva dos grupos de consumidores-eleitores é a maioria, presume-se implícita que a minoria resultante nos grupos cuja maioria vota pró-coalizão, revelaram sua preferência por sistemas privados, já que os sistemas autônomos municipais, por definição, eram menos eficientes que o esperado de uma coalizão ${ }^{179}$.

\footnotetext{
179 Também estamos admitindo que a maioria dos consumidores-eleitores que votou a favor da coalizão tenha se comportado racionalmente e motivacionalmente. E que, entre esses consumidores-eleitores, também possa haver aqueles que demandem serviços de saúde privados, mas se comportaram, segundo Williamson (1986), com “dignidade em relação aos necessitados” .
} 
Então, se adotarmos a definição de Raynaud (1999) para "grau" de seletividade" sobre um território como dado pelo número de ofertantes desse serviço que o dividem, o grau de seletividade do CISA seria igual "um", o que equivale à exclusividade territorial.

Raynaud (1999) utiliza a análise de Klein para explicar as razões desse resultado, a qual nós aproveitamos a seguir. Relembrando que $\mathbf{B}^{\mathbf{1}}$ representa o valor presente descontado dos bônus políticos (podendo ser expresso em participação no volume de votos) que uma elite política municipal possa ganhar "trapaceando", ou seja, agindo oportunisticamente. E, que $\mathbf{B}^{2}$ é o valor presente descontado da corrente de prêmios (bônus político) que uma elite política municipal possa ganhar agindo conforme as normas de funcionamento do consórcio.

Em assim sendo, uma dada elite política municipal agirá conforme as regras, se lhe for custoso enganar, isto é, se $\mathbf{B}^{\mathbf{2}} \geq \mathbf{B}^{\mathbf{1}}$, ou seja, haverá a auto-coercitividade.

Se $\mathbf{B}^{1}$ for constante, então a corrente de prêmios é igual a $\mathbf{B}^{2}$ no caso de completa exclusividade territorial e seria $\mathbf{B}^{2}(\mathbf{n})^{181}$ no caso de uma exclusividade dividida; resultando, portanto, que alguma das elites políticas municipais envolvidas teria $\mathbf{B}^{\mathbf{2}} \geq \mathbf{B}^{\mathbf{2}}(\mathbf{n})$ se $\mathbf{n}>\mathbf{1}$.

Portanto, "ceteris paribus", a corrente de rendas políticas futuras recebidas por uma dada elite política municipal, na situação de um único consórcio no mesmo território, tende a ser mais alta. Até porque os comportamentos oportunísticos e os conflitos resultantes das externalidades entre os Municípios tendem a ser mais intensos no caso de divisões territoriais dos serviços prestados, resultantes do fracionamento da coalizão original em sub-coalizões.

Ainda sobre esse aspecto, façamos uma digressão lógica. Até aqui, admitimos que $\mathbf{B}^{\mathbf{1}}$ era fixado, mesmo sabendo da correlação positiva entre o aumento de

\footnotetext{
${ }^{180}$ Raynaud (1999) trabalha com esse grau de seletividade como um parâmetro para relativizar a fraqueza do mecanismo de coerção.

181 A título de exemplo, pensemos em n como o número de consórcios existentes na área. Isso seria possível se considerarmos a possibilidade de algum dos Municípios envolvidos se retirar do consórcio original, ou mesmo, parte da coalizão agir em conluio, de tal modo que, utilizando-se das vantagens atribuídas pelas regras sobre o patrimônio, busquem instalar os mesmos serviços em sua(s) jurisdição(ões).
} 
$\mathbf{B}^{1}$ e a necessidade de regras auto-coercitivas. Porém, considerando essa correlação, poderemos inferir que quanto maior for o número de coalizões no mesmo território, maior a competição pela qualidade de serviço prestado, facilitando às elites políticas se comportarem oportunisticamente (afinal, aumenta-se o número de prestadores dentro do território competindo pelos mesmos consumidores-eleitores).

Portanto, maior tende a ser o fluxo ${ }^{182}$ futuro $\mathbf{B}^{\mathbf{1}}$, cuja expectativa incentiva o comportamento ineficiente das elites em relação à coalizão com a qual esteja envolvida. Ou seja, podemos inferir que os consequientes comportamentos de "free-rider" das elites políticas municipais, nesse cenário, tornaram-se mais vantajosos ${ }^{183}$.

Isso sugere que, num mesmo território, a evolução do número de coalizões poderia gradualmente retirar o aspecto "auto coercitivo" das regras, quando então teríamos $\mathbf{B}^{2}(\mathbf{n})<\mathbf{B}^{\mathbf{1}}(\mathbf{n})$.

De qualquer forma, isso vale como digressão lógica, pois, a hipótese do aumento do número de coalizões no mesmo território é pouco provável. De início, seria necessário que ocorressem conluios, e a conseqüente formação de sub-coalizões. Porém, ainda assim, cada sub-coalizão teria seu próprio território, voltando à condição inicial deste cenário. O que fica como possível neste cenário é a competição pela qualidade do serviço prestado entre sub-coalizões formadas da mesma, desde que a mobilidade dos consumidores-eleitores lhes possibilite escolher entre elas.

Raynaud (1999), novamente citando Klein (1996), esclarece em seu trabalho que o aspecto "auto coercitivo" das regras dos contratos pode ser modificado por condições externas, tais como a evolução dos mercados que não cobre todas as possíveis contingências futuras. Dessa forma, relembrando nossa citação de Sappington (1991) em seção anterior, conjugado com a postura de Klein (1996), dois

\footnotetext{
${ }^{182}$ Neste caso, nos é possível identificar pelo menos dois fatores que comporiam o fluxo futuro pretendido pelas elites políticas envolvidas, os quais se inter-relacionam: o fluxo advindo do comportamento benevolente das elites políticas, de efeito redistributivo, expresso na melhoria dos padrões de saúde pública aos consumidores-eleitores demandantes; e, o conseqüente fluxo político, resultante da avaliação expressa em votos que a maioria de consumidores-eleitores demandante do sistema, e daqueles solidários a eles, fazem da qualidade dos serviços tomados.

183 Principalmente, se considerarmos constante o grau de mobilidade dos consumidores-eleitores dentro da região, à medida que as divisões territoriais fossem ocorrendo; e se desconsiderarmos questões como a escala dos serviços.
} 
elementos se apresentam como necessários para a estabilidade da estrutura de governança: um mecanismo no contrato que lide com conflitos entre os envolvidos; e, a habilidade para adaptar a governança às mudanças de situações; sem que isso signifique o enfraquecimento do contrato com a possibilidade de renegociações.

Quanto ao gerenciamento de conflitos no CISA, representamos abaixo uma análise a partir dos conceitos de Williamson (1985 e 1991), na qual se destacam, em particular, as cláusulas de salvaguarda do consórcio que estabelecem uma "hierarquia privada" para a arbitragem e o processo dos envolvidos, elites políticas municipais e burocracia, diante de conflitos ${ }^{184}$.

Figura II: Possível estrutura para o gerenciamento de conflitos em uma coalizão

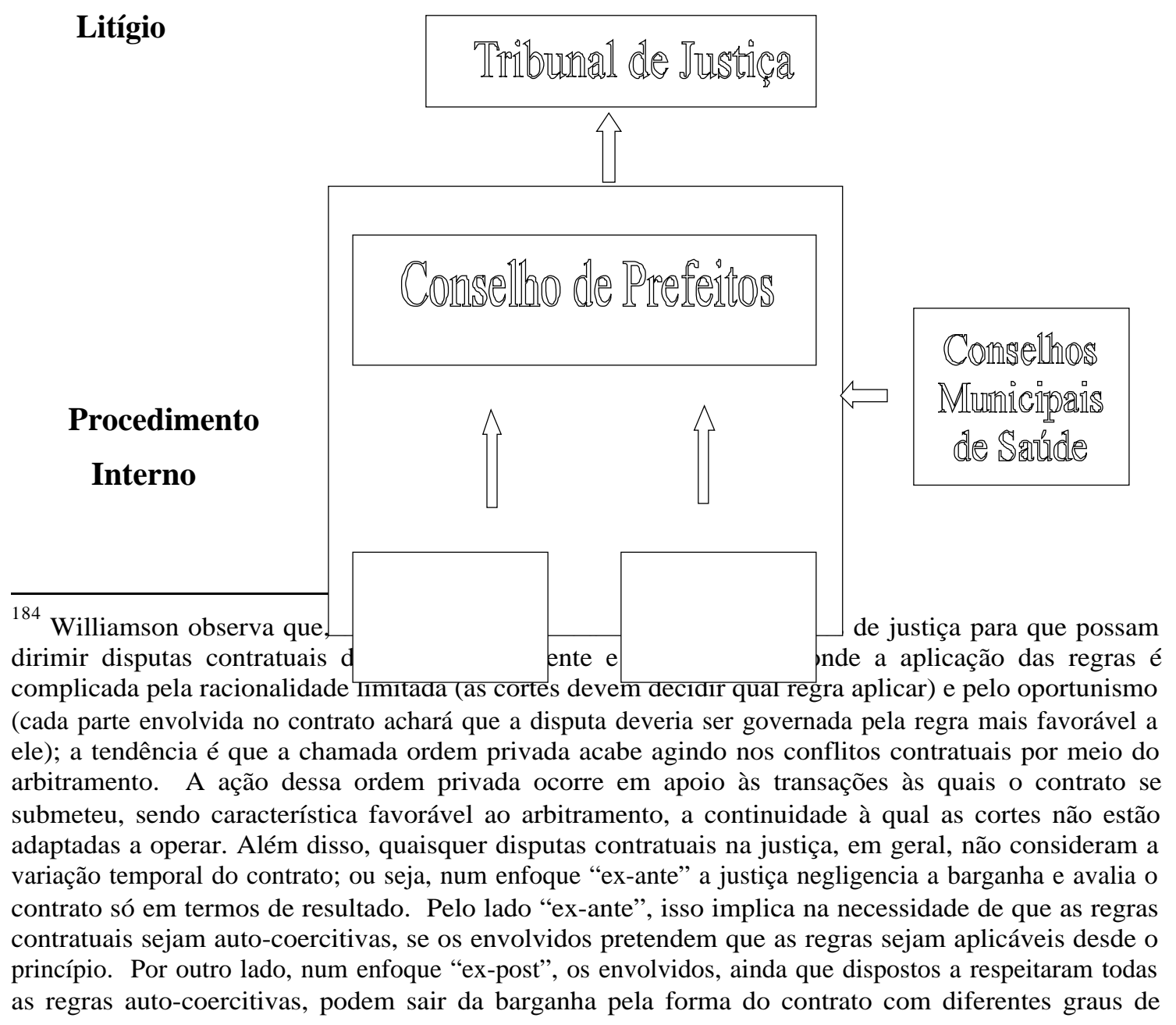




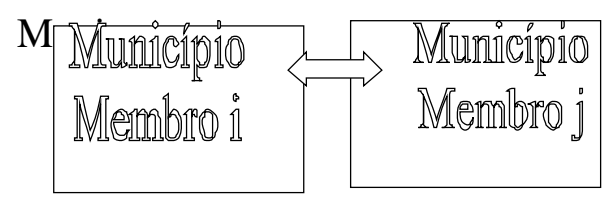

A expressão concreta de procedimento de arbitragem é a existência de um "Comitê de Prefeitos", órgão decisório máximo composto pelos prefeitos dos Municípios envolvidos, sendo a presidência exercida, em geral, pelo prefeito do Município-sede, com regra de decisão que varia de maioria simples a absoluta, através de "uma pessoa, um voto".

Quanto à tomada de decisão por regra de maioria, e, com base em Ostrom (1986), cumpre-nos abordar como esse Conselho de Prefeitos pode lidar com as falhas na tomada de uma decisão unânime. A idéia é de que, entre as regras que norteiam o funcionamento desse Conselho, existam aquelas que visem à segurança institucional e a manutenção da própria coalizão, quando ocorrer alguma dessas falhas de tomada de decisão.

Uma primeira regra poderia estabelecer que, diante de uma falha de decisão do Conselho, cada Município continuaria a receber sua alocação anterior de serviços de saúde pública, mantendo-se o "status quo" inequivocamente especificado e conhecido antes de o encontro começar.

Uma outra possibilidade seria a redistribuição desses serviços diante de uma regra já estabelecida no contrato constituinte, ou seja, as condições iniciais observadas na constituição da coalizão. Uma terceira regra para lidar com a falha do Conselho poderia ser algo intermediário previsto em contrato, tal como, a compulsória redistribuição dos serviços seguindo um determinado critério de proporcionalidade observado naquele momento da falha de tomada de decisão.

Evidentemente, a existência ou não dessas regras pode afetar as situações em que ocorrem as falhas de tomada de decisão, da mesma forma que as condições de falha também afetam o comportamento de todos os personagens envolvidos direta e indiretamente na barganha.

satisfação, significando que os envolvidos poderiam avaliar a eficiência obtida pela coalizão sob diferentes regras contratuais coercitivas. 
Afinal de contas, as decisões sobre a alocação de serviços públicos de saúde entre os Municípios envolvidos na coalizão, e representados no Conselho de Prefeitos, tenderiam a se deslocar para as condições desenhadas pela regra a ser aplicada diante de uma falha de tomada de decisão, dando-nos a entender que as decisões do Conselho de Prefeitos devem ser substancialmente influenciadas, se não completamente determinadas pelas consequiências das eventuais falhas.

Porém, se diante de uma falha, um Município tido como "privilegiado" ou "intermediário", tal qual Penápolis, preferir fortemente outro resultado que não o esperado de uma regra de falha adotada "ex-ante", então qualquer outro Município poderá ameaçá-lo com uma falha, a menos que o resultado final da barganha seja motivado exclusivamente pela maximização dos benefícios esperados da coalizão.

No entanto, quando algum Município, que pode até ser um "latente”, preferir o resultado estabelecido na regra de falha, ele pode esforçar-se em bloquear qualquer proposta que não se aproxime dessa condição.

De qualquer forma, o que se observa especificamente no Conselho de Prefeitos do consórcio de Penápolis, é que os poderes de coerção desse comitê se restringem ao aspecto moral, não detendo o poder de infligir alguma penalização às elites políticas municipais envolvidas. Suas principais funções são a intervenção como árbitro em algum conflito e a escolha da diretoria do consórcio.

Não se esclarece no trabalho de Ribeiro e Costa (1999) se esse comitê, não tendo sucesso em lidar com um conflito, teria alguma regra de falha de decisão (ou seja, de conciliação), ou se prevê algum outro órgão externo a quem transferir a tomada de decisão.

Esses autores apenas relatam a existência dos Conselhos Municipais de Saúde, que, por estarem próximos dos consumidores-eleitores, proporcionam a estes o compartilhamento das decisões normativas e exercem o controle social da política pública de saúde. Com isso, poderíamos concluir que os Conselhos Municipais de Saúde representam o apoio político às soluções de conflitos sob responsabilidade do Conselho de Prefeitos.

Quanto à estrutura executiva do CISA, Ribeiro e Costa (1999) chamaram a atenção para o comportamento intencional de se posicionarem à margem dos conflitos 
políticos, até como um comportamento oportunístico expresso por uma regra informal entre a burocracia do consórcio e as elites políticas municipais, como uma estratégia dos primeiros em ampliar a sua própria autonomia e assegurar algum grau de isolamento dos conflitos políticos. E, por isso mesmo, não seria uma segunda opção na solução desses mesmos conflitos.

Todavia, a burocracia da coalizão dificilmente poderá se furtar a envolver-se em conflitos entre os Municípios, principalmente aqueles que impliquem em regras de exclusão $^{185}$ ou, naqueles outros que tenham origem em alguma ameaça de saída. Afinal, segundo Raynaud (1999), para Klein, qualquer personagem que reduza a possibilidade de expulsão, reduz a eficiência dos mecanismos de coerção, mesmo que esses mecanismos dependam de fatores externos, tais como a justiça comum que poderia ser aplicável na situação de suspensão unilateral do recolhimento da cota financeira.

No CISA, esses limites são ainda "internos", ou seja, com a aplicação de sanções que impedem o acesso dos respectivos consumidores-eleitores, com os conseqüentes ônus políticos, mesmo porque, além das conotações políticas de uma expulsão, será sempre mais difícil excluir um dos "proprietários" do consórcio. E, além disso, qualquer enfraquecimento no poder de se romper alguma relação, limita os mecanismos de coerção sobre esta.

Portanto, achamos interessante a busca de algum outro elemento que modifique os incentivos ao comportamento oportunístico, através de um redesenho interno de contrato, e que embuta em si um esquema "auto coercitivo", ou seja, $\mathbf{B}^{2}(\mathbf{n})>$ $\mathbf{B}^{1}(\mathbf{n})$.

A priori, poderíamos pensar em como se ampliar os ganhos das elites políticas municipais envolvidas em razão de agirem dentro das regras, ou, os seus custos políticos por trapacear. Afinal, aumentar os ganhos implica aumentar fluxo de seus rendimentos político-eleitorais.

Algumas soluções são possíveis, ao menos em teoria. Entre elas, a ampliação da qualidade dos serviços médicos à medida que também se amplie a capacidade e a

\footnotetext{
185 Não temos conhecimento de que exista no contrato de constituição do CISA qualquer regra de exclusão.
} 
autonomia da burocracia do consórcio em propor incentivos à contratação de melhores médicos especialistas. Na prática, é uma solução de difícil implementação, dada a necessidade de uma correspondente ampliação dos valores de todas as cotas financeiras a cada Município envolvido na coalizão.

Uma alternativa é criar penalidades aos Municípios que queiram abandonar o consórcio, implantando sistemas de serviço público similares e reduzindo o grau de seletividade territorial. O problema é que essa solução também possui dificuldades de implementação em razão das características da pessoalidade dos agentes, ou seja, tratase de Municípios, pessoas de direito público. $\mathrm{O}$ dano possível por não se implementarem tais penalidades, como já vimos, dá-se com a proximidade territorial do Município que se retira, e com a mobilidade dos consumidores-eleitores.

Essas duas variáveis vão exigir algum incentivo negativo das elites políticas municipais que se retiram junto aos respectivos consumidores-eleitores para que estes últimos "re-acomodem" suas respectivas funções utilidades aos padrões de serviço de saúde pública oferecidos em suas jurisdições.

Para que isso ocorra, obviamente é necessário que os consumidores-eleitores "transferidos" estejam de acordo com a qualidade percebida dos serviços ofertados em suas jurisdições, o que implica às respectivas elites políticas conhecer as características do consumidor-eleitor mediano "transferido", se não de todos eles, arcando com os custos de revelação dessa informação, que tendem a serem muito elevados.

Portanto, dada a dificuldade de se influenciar $\mathbf{B}^{2}$, as possibilidades de modificar $\mathbf{B}^{\mathbf{1}}$ parecem mais fáceis. $\mathrm{O}$ contrato de prestação de serviços médicos especializados aos consumidores-eleitores dos Municípios envolvidos pode ser modificado a fim de tornar mais crível a ameaça de seu término, sem que se recorra a instâncias externas tais como um tribunal.

No caso do CISA, duas cláusulas tem essa intenção. Uma delas se refere às regras de acesso ao serviço prestado, de modo a restringi-lo apenas aos consumidoreseleitores dos Municípios que fazem parte do sistema, e indiretamente expõem as obrigações das elites políticas desses Municípios além de estabelecer alguma autoridade à burocracia do consórcio, o que pode ferir o princípio constitucional da universalidade do acesso. 
A outra cláusula é a que introduz um ônus político, quando limita o acesso aos consumidores-eleitores dos Municípios que não estão em conformidade com suas obrigações contratuais. Quanto a esta última, Ribeiro e Costa (1999) não fazem referência a qualquer forma de penalidade financeira no contrato de constituição do CISA. De qualquer forma, a quantidade destas penalidades deve ser progressiva, de acordo com os danos potenciais, a fim de reduzir $\mathbf{B}^{\mathbf{1}}$.

\section{6. algumas considerações}

A teoria dos contratos aplicada à coalizão intermunicipal a partir da literatura de franchising se mostra interessante para o estudo "ex-post" à sua constituição, envolvendo a estrutura de governança. Portanto, interessante para se estudarem os aspectos relacionados aos comportamentos oportunísticos das elites políticas também “ex-post", tais como o "caronista", e as questões que envolvam monitoramento e controle, facilitando a previsão de suas respectivas cláusulas "auto coercitivas".

Por outro lado, as questões atinentes à organização da cooperação, tais como as motivacionais dos personagens, as que relacionam aos possíveis comportamentos oportunísticos "ex-ante" das elites políticas, e, o necessário esforço de coordenação e indução à constituição da coalizão pelas assimetrias existentes entre os personagens, ficaram a margem desta aplicação teórica adaptada de um caso de franchising.

$\mathrm{Na}$ realidade, uma boa parte dessa literatura se mostra insuficiente para explicar quais as motivações das diversas elites políticas em assumirem um comportamento cooperativo, na medida em que é voltada à formação de uma rede prestadora de serviços compostas por agentes iguais, na qual o papel de monitorador atribuído ao franqueador, o principal, é em muito facilitado por essa condição. Inclusive, como já observado no modelo de Hölmstrom (1982), o principal, sem exercer monitoramento, possui um mecanismo de coerção apoiado exclusivamente em penalidades críveis.

Evidentemente, essa necessária igualdade não é encontrada entre os Municípios envolvidos, embora sejam entes federativos que detêm igual autonomia 
administrativa e tributária. Afinal, como procuramos demonstrar nos capítulos anteriores, essa desigualdade entre os Municípios existe sob vários aspectos. Abordamos, entre outros, os atinentes ao equilíbrio orçamentário, e às assimetrias encontradas na racionalidade das elites políticas municipais no trato dos compromissos "versus" os respectivos custos políticos em empreendê-los.

Também reconhecemos nos capítulos anteriores que os consumidoreseleitores tinham diferentes funções utilidade. Com isso, as decisões coletivas de cada grupo deveriam possuir propensões próprias, o que nos permitiu também concluir que os grupos formados por eles teriam o consumidor-eleitor mediano com propensão pró cooperação diferentes entre si. Diga-se de passagem, no capítulo anterior, chegamos a propor, inclusive, a classificação desses grupos de consumidores-eleitores a partir de Olson (1971), em pelo menos quatro possíveis tipos: monopsônicos, privilegiados, intermediários e latentes. Cada um desses enquadramentos disporia de uma tendência predominante a assumir uma posição pró ou contra cooperação, e, portanto, com diferentes necessidades de incentivos seletivos e de coordenação.

Constatada a desigualdade entre os vários Municípios, e, portanto, a inadequabilidade desta literatura em explicar a nossa questão central (a motivação, a indução e a coordenação à cooperação intermunicipal), retornamos à literatura de escolha coletiva, com enfoque na literatura institucionalista e federalista, para abordarmos, no capítulo seguinte, especificamente a União, por meio do SUS, e o seu possível papel de indutor da cooperação intermunicipal, notadamente a estruturada sob a forma de convênios intermunicipais (convênios). 


\section{CAPÍTULO IV}

\section{AS MUDANÇAS NO AMBIENTE POLÍTICO-INSTITUCIONAL E INDUTOR DA COOPERAÇÃO INTERMUNICIPAL}

\section{1. apresentação}

Encontramos em Shirley (1997) o conceito de que uma mudança das instituições começa com uma ação coletiva às vezes não bem identificada. Porém, as condições iniciais, a evolução histórica, a informação e o aprendizado são características da mudança institucional, sugerindo-nos que essa mudança é gradual e, em geral, inovadora, enquanto que a opção a essa definição inicial de transformação institucional é a ruptura. Embora, não necessariamente, a ruptura represente uma mudança, na medida em que ela implique numa substituição institucional.

De qualquer forma, para que um ente federativo seja eficaz são necessárias instituições confiáveis, com o cumprimento das normas estabelecidas, e que qualquer dos personagens acredite que elas serão obedecidas por todos.

\section{2. uma visão da teoria institucional aplicada ao SUS}

Segundo Eggertsson (1996), existem pelo menos três casos hipotéticos de sociedade. Existem as sociedades que não possuem estruturas jurídicas, legislativas, nem possuem agencias que monitorem e coagem o cumprimento de regras, ou seja, não possui regras comuns. Há aquelas que só possuem regras comuns que especificam os direitos exclusivos de propriedade, o corpo legislativo, as cortes de justiça, mas, não possuem o poder de polícia para fazer cumprir as regras. E há aquelas, tais como o Estado, as quais estabelecem as regras, fazem a arbitragem em disputas e fazem valer os direitos exclusivos, quer sejam coletivos ou individuais. 
A partir desses três casos, Eggertsson (1996) correlaciona regras com o grau de incerteza, de forma que o primeiro tipo de sociedade tem maior grau de incertezas do que o segundo, que por sua vez, tem maior grau de incerteza que o terceiro. O que este autor conclui, é que há uma correlação direta da incerteza com a falta de regulamentação e de seu monitoramento.

Portanto, o grau de incerteza em uma sociedade também se correlacionaria diretamente com os custos de transação, na medida em que não se garantam os direitos de propriedade e, os contratos. Em suma, o fato da não existência de um órgão regulamentador, que se incumba da "coercitividade", permite comportamentos oportunísticos e altos custos de informação.

E não poderia ser diferente. Afinal, os problemas identificados ao longo deste trabalho, principalmente os de informação, de coordenação e de contrato incompletos, são os mesmos com os quais o SUS necessita lidar e, ao mesmo tempo, o impedem de ser deixado por conta própria. Além disso, os serviços públicos de saúde requerem padrões de auditoria a partir do Ministério de Saúde, acompanhados de sistemas legais que desincentivem os comportamentos oportunísticos e forneçam as informações adequadas sobre os recursos disponíveis.

É por isso que a simples transparência das ações e tomadas de decisão por si mesma não é o suficiente, na medida em que, inevitavelmente, a informação é incompleta. Talvez a solução seria o SUS combinar a regulamentação com o monitoramento ("controle social") para mitigar os problemas de informação e fomentar as condições para que se prestem serviços de saúde pública eficientes.

De qualquer forma, há a necessidade de regulamentação, embora haja pelo menos três condições para isso, as quais adaptamos de Stiglitz (1998) ao presente caso. Primeiro, a regulamentação deve conduzir o sistema como um todo a uma situação mais eficiente, o que pode significar a exclusão de medidas que restringem a cooperação, substituindo-as por outras que a induzam. Segundo, uma vez desenhado o sistema de saúde pública, a União, reconhecendo sua limitação informacional, deveria efetivar a sua implementação gradualmente, de modo a proporcionar aos Municípios alguma margem de adaptação às circunstâncias regionais. Terceiro, a regulamentação deveria assegurar aos Municípios o mesmo padrão de incentivos, ampliando a 
possibilidade deles se monitorarem, reduzindo esses custos na União, até porque ela não tem condições de fazê-lo amplamente.

Por outro lado, se nos restringirmos apenas à União usando a regulamentação para a promoção dos serviços públicos de saúde, provavelmente, a solução ainda não terá a eficiência esperada. Afinal, qualquer mecanismo de regulação também deveria promover incentivos para que a prestação desses serviços se aproxime da qualidade desejada pelos grupos de consumidores-eleitores, inclusive, induzindo a formatação de estruturas voltadas à cooperação regional.

Ora, se podemos intuir que a cooperação intermunicipal é essencial em várias regiões do Brasil para que as respectivas populações municipais obtenham o benefício esperado de saúde pública, então, também é necessário que o SUS reconheça a cooperação intermunicipal como uma possibilidade importante em sua normatização.

Tanto que, na hipótese da União vir a adotar uma postura "descuidada" em relação à regulamentação do serviço público de saúde, ainda assim, a cooperação intermunicipal seria importante. Se assim não o fosse, possivelmente não teríamos o exemplo do CISA abordado no capítulo anterior, que se constitui na organização da cooperação intermunicipal, no formato de uma coalizão, voltada à melhoria da qualidade da prestação de saúde pública na região de Penápolis-SP, cuja fundação, além de espontânea, precedeu a organização do SUS.

Assim, o que de fato se busca é uma estrutura regulamentadora que se adapte a este e a outros tipos de desafios, promovendo a cooperação e a eficiência na prestação de serviços públicos de saúde. Porém, mesmo a cooperação possui imperfeições, afinal vimos nos capítulos anteriores a possibilidade de se formarem conluios políticos e subcoalizões.

Portanto, o estabelecimento de regras e incentivos seletivos voltados a resolver estes tipos de imperfeição são temas que deveriam ser tratados adequadamente por todos os envolvidos, inclusive o SUS, o qual, em especial, ainda teria a vantagem de atuar sobre essa questão de modo imparcial e independente dos demais personagens, induzindo-os realmente à cooperação.

Por outro lado, para que a União assuma o papel de regulamentador das ações de governos municipais, ela própria deveria estar ajustada a este papel e provida de 
suficiente capacidade instrumental para efetivar esses ajustes institucionais. Afinal, o fortalecimento de uma instituição ${ }^{186}$ implica não apenas a construção de capacidades administrativas e técnicas, mas também, a constituição de normas e regras que forneçam os incentivos, que voltados à cooperação intermunicipal, seriam dirigidos às elites políticas municipais para que atuem no interesse de seus respectivos grupos de consumidores-eleitores, restringindo o auto-interesse e, portanto, os comportamentos oportunísticos.

\section{1. o SUS observado como uma estrutura de coordenação}

A literatura sugere duas interpretações contrastantes do porque diferentes organismos se juntariam numa configuração social complexa. A primeira baseia-se no fato de que as instituições são funcionalmente vinculadas às praticas de usos e costumes em constante evolução em cada época e lugar; podendo dar-se pelo processo de tentativa e erro, uma identificação de objetivos comuns.

A outra interpretação, e talvez a mais pertinente a este estudo, surge de uma critica aos neoclássicos, segundo a qual, os mecanismos de coordenação econômica, tais como diferentes tipos de hierarquias ${ }^{187}$, redes e associações, impõem restrições na definição de necessidades, preferências e escolhas dos personagens econômicos; ainda que também tenham objetivos comuns. Ou seja, enquanto a interpretação neoclássica assume que o indivíduo é soberano, a segunda argumenta que a ação individual é afetada pela influência que as instituições têm no processo de tomada de decisão individual.

\footnotetext{
${ }^{186}$ Stiglitz (1997) defende que o fortalecimento do mecanismo regulacional também deva ser conjugado com “(...) a presença de um poder judiciário independente, com a divisão de poder, e a adoção de princípios de suspensão efetiva, (...)" , de modo a que os governos envolvidos, os das três esferas federativas, respondam aos interesses dos cidadãos.

187 A hierarquia na prestação dos serviços públicos de saúde (diga-se: um dos objetivos das normatizações do SUS) pode ser observada na atribuição a quem toma a decisão se um determinado serviço é prestado por uma estrutura pulverizada de postos de saúde voltada às ações básicas de saúde, ou por um hospital de referencia regional.
} 
Portanto, a questão que ressurge é se haveria um arranjo institucional ideal para o SUS. Evidentemente, independente de ser voltado ao SUS, é fácil intuirmos que um arranjo institucional ideal e pré-formatado não existe. Afinal, um arranjo institucional depende de características que podem ocorrer em razão de vários fatores, desde a imposição de restrições (tais como, a orçamentária), até a situação geográfica e as características dos vários grupos de consumidores-eleitores, os quais, em última instância, são o alvo de qualquer política pública.

Além disso, prover eficiência a um arranjo institucional como o SUS, pode depender de fatores intermunicipais, tais como o grau de competitividade ou de cooperação, principalmente, aqueles manifestados espontaneamente. Da mesma forma, essa mesma dependência pode também estar condicionada a fatores intramunicipais, tais como a decisão de se fracionar o atendimento do sistema de saúde pública em postos comunitários (estruturar uma rede de prestação de serviços), ou, então, concentrá-lo em alguns centros de referência municipal e, às vezes, até de referencia regional.

Uma observação que Hollingsworth (1997) faz, e que consideramos aplicável tanto ao SUS quanto às coalizões intermunicipais, é que quando não se tem certeza se a qualidade do serviço corresponderá ao esperado e o incremento dos ganhos de escala se estabelece como principal motivação, então, a tendência com o surgimento de outras contingências é o aumento da incerteza e da quantidade de transações repetitivas, evidenciando-se a falta de coordenação.

Evidentemente, é uma situação que conduz ao risco de não se conseguir otimizar as performances dos serviços prestados, principalmente, os de técnicas médicas e laboratoriais mais complexas, ou que mudam muito rapidamente. Sem mencionar que esta situação pode se agravar pelo crescente volume de demanda de serviços públicos de saúde, o que, novamente, evidencia a necessidade de algum mecanismo de coordenação ${ }^{188}$ que possa, inclusive, ser formado a partir da própria configuração que o sistema for assumindo.

188 Hollingsworth (1997) define coordenação econômica como o processo pelo qual as relações econômicas são organizadas na forma de uma matriz de transações interdependentes, envolvendo atores e organizações nas funções de desenvolvimento, produção e distribuição de bens e serviços. Sob uma 
Ou seja, se considerarmos desde as questões jurídicas, tais como as que envolvam a Constituição Federal, passando pela legislação pertinente, até princípios morais, tais como a universalização do acesso, consideramos possível que se encontre algum mecanismo de coordenação dos fatores de produção de serviços de saúde pública, formatado pela coexistência destes vários tipos de valores sociais, sem que necessariamente, ocorra a imposição de um determinado mecanismo exógeno.

Por isso, seria também interessante identificarmos na solução adotada para o exercício da coordenação, pelo menos, os seguintes dois enfoques que se interelacionam: a forma adotada de gerenciamento de uma dada coordenação econômica, e o modo com que essa coordenação se estrutura. Entre as formas de gerenciamento, estas podem variar de uma visão de racionalidade puramente econômica, pela qual os agentes se apresentam com auto interesse, a uma visão puramente sociológica, pela qual a obrigação no modo de agir vincula-se às regras sociais que guiam os princípios formadores da ação humana.

Por outro lado, o modo de estruturação da coordenação pode variar como uma combinação linear entre as interações de iguais envolvendo muitos agentes, até uma estrutura inteiramente hierarquizada, com desigual distribuição dos resultados entre seus componentes, passando pela possibilidade de uma relação entre um principal e os agentes. Essa diversidade induz que a coordenação econômica assuma várias formas $^{189}$.

Observe-se que, enquanto buscarmos definir quais seriam as formas de coordenação econômica aplicáveis, principalmente ao SUS, devemos manter em mente que os tipos de arranjos institucionais que formariam um padrão, em razão do qual pudéssemos enquadrar as coalizões intermunicipais e o SUS, variam em função da

outra ótica, coordenação econômica é o processo pelo qual essas funções são gerenciadas através de vários atores.

${ }^{189}$ Hollingsworth (1997) classifica as estruturas de coordenação, basicamente, como sendo da seguinte forma: mercado, comunidade, hierarquia privada, rede e o Estado. 
natureza da motivação ${ }^{190}$ e da distribuição de poder e, conseqüentemente, da distribuição de bônus sobre os resultados entre os agentes ${ }^{191}$.

Portanto, seja qual for a escolha da estrutura do mecanismo de coordenação que se insere no cenário que desenhamos, há que se considerar, não somente a existência das transações, mas também em que grau as limitações nas relações entre a União e os Municípios envolvidos, incluindo as relações intermunicipais, afetam essas transações.

Assim sendo, principiamos pela estrutura abordada no capítulo anterior, e denominada por rede. A estrutura em rede é uma associação formal voltada à troca unilateral, com regras que, além de restringirem o acesso de novos envolvidos, se caracterizam pela compulsoriedade. As redes, em geral, possuem uma administração privada e os envolvidos nela, além de terem suas motivações variando do auto interesse às obrigações contratuais, são personagens formalmente interdependentes e iguais.

Inclusive, foi por essas razões que consideramos inadequada a literatura aplicada a franshising para explicar os Municípios envolvidos em coalizão, os quais, embora iguais federativamente, não são necessariamente interdependentes, e nem tão pouco iguais em termos de recursos disponíveis e de necessidades de serviços de saúde pública.

Uma outra estrutura de coordenação é a de mercado e, talvez, a estrutura mais analisada pela teoria econômica. Em geral, os mercados apresentam-se com liberdade de entrada e saída, e voltados à troca bilateral e voluntária. Também possuem normas sobre direitos de propriedade privada, a fim de legitimar as transações realizadas em seu meio.

Além do mercado, há a estrutura chamada de comunidade. Em geral, essas estruturas apresentam-se como uma associação informal, voltada à troca voluntária baseada na solidariedade social com alto grau de confiança, normas sociais e princípios

\footnotetext{
${ }^{190}$ A motivação, como já observado em capítulos anteriores, varia entre o auto-interesse e a obrigação.

191 A distribuição dos resultados, como observado no parágrafo anterior, varia com as inter-relações entre os indivíduos, organizações (desde aquelas que envolvem a igualdade entre agentes, até aquelas que pressupõe uma hierarquia).
} 
morais que impõem obrigações e normas e regras altamente institucionalizadas que requerem que os envolvidos aceitem algumas obrigações comportamentais.

É evidente que, tanto os mercados quanto as comunidades, são incompatíveis como estrutura de mecanismos de coordenação voltados à cooperação intermunicipal, tendo em vista que as ações dos Municípios envolvidos são individualizadas na pessoa das respectivas elites políticas. Além disso, esses indivíduos têm tendência a comportamentos oportunísticos e, portanto, exigem a credibilidade em contratos formais e auto coercitivos.

Há também a estrutura de coordenação na forma de uma hierarquia privada. Em geral, apresenta-se como uma organização complexa e burocrática. Embora a entrada e a saída dos envolvidos seja restrita, seu processo de tomada de decisão baseiase no poder assimétrico e em regras burocráticas. Por outro lado, os envolvidos são induzidos a comportamentos corporativos por meio de incentivos positivos e negativos, baseados em recompensas e ameaças de sanções.

Esta estrutura também é inadequada como mecanismo de coordenação da cooperação intermunicipal, na medida em que os Municípios envolvidos são politicamente iguais e administrativamente independentes. Além disso, permanece o paradoxo evidenciado no capítulo anterior, de que os Municípios, embora constituam uma coalizão com regras auto coercitivas, não se subordinam entre si e nem em relação à burocracia da coalizão, uma vez que o eventual poder de decisão de sua burocracia vincula-se à vontade política das elites municipais envolvidas.

Finalmente, temos a estrutura do Estado que poderia ser vista como uma "hierarquia pública". Ou seja, respeitadas as autonomias administrativas, trata-se de uma associação entre entes federativos, onde a regulamentação, quase sempre unilateral, das ações no âmbito das várias políticas públicas ocorre com base em normas coercitivas e regras sociais ${ }^{192}$. Além disso, a competência em elaborar a regulamentação, em geral, é definida entre os entes federativos pelo pacto constitucional.

192 Observe-se que, sendo previsível a coercitividade das regras, a obtenção do equilíbrio em uma
estrutura de "hierarquia pública" pode também se correlacionar com as soluções adotadas às ameaças de 
Em princípio, nos parece que o SUS, enquanto estrutura de coordenação da política pública de saúde no país, se aproxima de uma organização "hierárquica pública", onde os entes municipais são induzidos à prestação de determinadas ações padrões, na medida em que se adaptem às normas emitidas pelo SUS. Por conseqüência, pode-se identificar nesta estrutura de coordenação, a sua possibilidade de assumir o papel de indutor da cooperação intermunicipal neste setor público, a partir não somente das regras constitucionais instituídas em 1988, que lhe conferiram a capacidade de regulamentação dos serviços públicos de saúde, mas também, na vinculação destas ao financiamento das ações municipais no âmbito desta política pública por meio de transferências financeiras.

Resta, portanto, conferir se a partir do conceito de municipalização dos serviços de saúde pública, as mudanças institucionais ocorridas no SUS foram nessa direção.

\section{2. o SUS observado como um sistema social de produção}

O SUS poderia ser considerado um sistema social de produção no sentido que Hollingsworth (1997) procura atribuir às instituições ou estruturas de um país, ou de uma região, desde que essas estruturas e/ou instituições estejam integradas numa configuração social. Esse autor utiliza-se de três conceitos para tipificar os sistemas

saída (guerra fiscal e mobilidade, por exemplo), quanto na expressão da voz (voto, lobby ou mesmo controle social). 
sociais de produção: velocidade ${ }^{193}$ de ajustamento, volume ${ }^{194}$ e a competição pela qualidade $^{195}$.

O interessante deste enfoque é que, a partir da combinação destas variáveis, poderíamos até desenhar o que supomos ser o ideal como sistema social de produção de serviços públicos de saúde. Afinal, ainda que um sistema social de produção esteja voltado à produção em massa de algumas determinadas ações padrões, estes padrões poderiam ser suficientemente flexíveis ao longo do tempo, de tal forma que as suas mudanças pudessem influenciar nessa estrutura, a formatação de mecanismo de coordenação das coalizões intermunicipais.

Por outro lado, para se "projetar" uma organização ideal, também convém levar em conta variáveis exógenas, tais como: o componente territorial, o tipo de serviço de saúde pública em si, o sistema sócio-político e, o arranjo federativo. Porém, jamais deveríamos deixar de também observar as organizaçõos similares existentes, principalmente as tenham passado por algum processo de adaptação ao ambiente no qual se inserem, nas quais o nosso foco se estenderia também à trajetória de sua mudança institucional, a fim de capturarmos alguma tendência relevante.

Afinal, um sistema social de produção pode mudar não apenas pela busca incessante do resultado, mas também por outros fatores, dentre os quais: maximizar o critério de eficiência alocativa e distributiva, ampliar a confiabilidade e a estabilidade do sistema, proporcionar segurança contratual entre envolvidos no sistema, garantir a

\footnotetext{
${ }^{193}$ Velocidade de ajustamento é o tempo que o sistema, ou parte dele, leva para se adequar às novas condições e exigências (seja das necessidades dos grupos de consumidores-eleitores, da disponibilidade de recursos, ou do próprio ambiente político-institucional no qual se insere); e, em geral, se aplica às normas que regulamentam o processo de prestação de serviços, envolvendo tecnologia e a agilidade de mudar as funções de produção desses serviços.

${ }^{194}$ O volume refere-se a uma preferência por determinada padronização ou especialização, o que dará um resultado de maior ou menor volume de produção de um determinado serviço de saúde pública.

195 Competição pela qualidade está relacionada também com a preferência dos grupos de consumidoreseleitores por algum dos tipos de produção padronizados, indicando se a produção desse serviço será em massa ou especializada (menor quantidade com mais qualidade); sendo, portanto, um conceito aplicável ao tipo de serviço a ser prestado e a quem for o seu público alvo. Inclusive, a um grupo de consumidores-eleitores do tipo "latente" a preferência por serviços de saúde pública tenderia a ser geograficamente difusa e abrangente, enquanto que, aos grupos "monopsônicos" tenderia a ser concentrada e especializada.
} 
aplicação das regras tidas como auto coercitivas, equalizar ${ }^{196}$ o serviço prestado, aprimorar, quantitativa e qualitativamente, os serviços existentes de saúde pública municipais autônomos já existentes e, desenvolver novas técnicas de gestão pública.

Veremos no transcorrer deste capítulo que quase todos os fatores elencados acima estão entre os objetivos do SUS. No entanto, destacamos a equalização dos serviços prestados pelos Municípios que se inserem no SUS, que pode ser encontrada entre as motivações das primeiras normas técnicas operacionais emitidas. Ou seja, essas normas, a partir do princípio constitucional da municipalização dos serviços de saúde pública, pretenderam a implantação de padrões similares de ações de saúde indistintamente pelos Municípios brasileiros, de tal forma que, equalizar os serviços de saúde pública teria o sentido de convergir os vários sistemas municipais de prestação de serviços a um determinado padrão.

No entanto, a performance da prestação dos serviços municipais de saúde pública está intrinsecamente relacionada ao sistema social de produção desses serviços que vigora no país sob a denominação de Sistema Único de Saúde -SUS. Portanto, a performance municipal não dependeria só da tecnologia empregue, mas também de valores sócio-culturais de um ambiente institucional, no qual o SUS influi decisivamente por meio de normatizações e de transferências financeiras. E, além disso, a eficiência esperada na equalização da prestação de serviços junto aos vários grupos de consumidores-eleitores, a partir de normatizações de padrões de ações de saúde pública, é agravada pela assimetria informacional.

\footnotetext{
${ }^{196}$ Esta função do SUS envolveria a organização do trabalho, dos insumos e dos recursos da forma mais eficiente possível, de modo que todos os sistemas autônomos municipais tendessem para um dado modelo. Sobre essa conduta, há várias correntes procurando explicar as causas à equalização. A corrente da organização industrial argumenta que organizações com objetivos similares tendem a assumir uma estrutura e comportamento similar, até por otimização de seus processos, sob pena de desaparecerem. E, a corrente sociológica, anuindo a anterior, acrescenta a condição de que as organizações deveriam estar imersas em ambientes semelhantes para que ocorra essa convergência, pois seriam as restrições ambientais, com suas normas e regulamentos, que formam o comportamento organizacional. Enquanto isso, a economia de custos de transações argumenta que existem diferentes formas de governar, dependendo da variação do meio organizacional; ou seja, a forma de governo de cada organização dependeria do tipo de custo de transação que ela enfrenta, a partir do qual, existiria uma forma organizacional ideal.
} 


\section{3. um enfoque teórico das mudanças institucionais observadas no SUS}

Segundo North (1990), as instituições são as regras do jogo, ou, mais formalmente, são as restrições que modelam a interação humana, reduzindo incertezas e custos, e que afetam a performance da economia. Assim sendo, uma instituição evolui e pode ser alterada, na medida em que se constituem e se alteram as regras, sejam elas formais ou informais. Além disso, ainda segundo North (1990), se as instituições são as regras, então as organizações proveriam a estrutura para a interação humana.

Combinando esses conceitos, o grau de eficiência de uma instituição seria o resultado da interação entre as regras e a organização correspondente. E, se tratarmos o SUS como uma organização, assim como podemos também considerar qualquer estrutura de cooperação intermunicipal abordada no capítulo anterior, então, qualquer que seja a instituição atribuída ao SUS, esta estaria passível de alterações ao longo do tempo por conta da eficiência procurada nessa interação.

De qualquer forma, o papel principal das instituições é reduzir a incerteza; ou seja, é modelar uma estrutura para a interação humana. Contudo, as instituições evoluem, até porque também se alteram as escolhas disponíveis com o passar do tempo. A essa evolução gradual das instituições, North (1990) se referiu como um processo de mudança tipicamente incremental.

Desse modo, a mudança institucional incremental seria o resultado da relação entre instituições e organizações. Além disso, a mudança institucional pode também resultar de como os tomadores de decisão percebem e reagem às mudanças já ocorridas e, às mudanças possíveis de ocorrerem em meio a um conjunto de outras oportunidades, a partir das quais, esses indivíduos envolvidos decidem o que seria melhor alterar na instituição existente.

No entanto, a percepção dos tomadores de decisão se correlaciona com as oportunidades percebidas e não com a totalidade das existentes. Ou seja, cada escolha individual se sujeita à informação recebida e, portanto, à racionalidade do tomador de decisão. Em sendo verdade, infere-se que a evolução da ação coletiva também teria dificuldades, com implicações similares sobre a tomada de decisão voltada à cooperação. 
Segundo North (1990), a dificuldade de se obter a cooperação viria justamente do fato de que “(...) a postura neoclássica ${ }^{197}$ da racionalidade plena não existe no mundo real, na medida em que as negociações políticas não necessariamente se interagem repetitivamente entre umnúmero pequeno de indivíduos, e nem implicam em mútuo conhecimento das preferências” .

Além disso, como já observamos no segundo capítulo, as dificuldades da ação coletiva também dependem do tamanho do grupo, e da relação custo beneficio que se incorpora às matrizes de decisão dos indivíduos envolvidos. É por isso que, ao tratarmos de qualquer das estruturas voltadas à cooperação sob esta ótica, quer seja a coalizão ou o convênio, devemos também considerar outros custos nessa matriz de decisão, tais como, os de monitoramento e os de coerção ${ }^{198}$.

Inclusive, se, a partir de North (1990), a relevância das instituições é diretamente proporcional ao nível de cooperação entre os envolvidos, então, as dificuldades para a evolução da ação coletiva devem também se correlacionar com as mudanças institucionais, inferindo-se que, quanto mais intensa for a cooperação, maior seria a necessidade de eficiência institucional a fim de se minorar o custo de transação durante o processo de evolução.

A razão para essa digressão lógica é que sendo a cooperação custosa, pois envolve custos de transação que podem ser elevados a ponto de inviabilizarem a cooperação, a instituição se torna importante, porque reduziria os custos relacionados à incerteza e aos comportamentos oportunísticos, por meio de monitoramento e de coerção.

\footnotetext{
${ }^{197}$ Uma possível postura neoclássica aplicável ao presente tema seria se afirmar que as elites políticas tendem a maximizar o bem estar do grupo de consumidores-eleitores que representam, pois consideram plenamente racional cooperar com os demais Municípios, principalmente se possuírem informações completas sobre a performance dos demais Municípios na prestação dos serviços de saúde pública e se existir um número pequeno de envolvidos com os quais façam repetidas interações.

198 Inclusive, alguns valores como o altruísmo poderiam ser abordados como benefício ao tomador de decisão. Esses valores altruístas podem se expressar nas normas e crenças comuns, no relacionamento direto e complexo entre os Municípios envolvidos, e na reciprocidade; os quais minimizariam a necessidades de uma ação coerciva pelo estabelecimento da cooperação. Afinal, o comportamento dos indivíduos também é determinado por motivos altruístas; de tal forma que eles fariam um "trade-off" entre duas funções de utilidade (aquela que favorece a preferência do grupo e aquela que favorece suas próprias preferências). Por outro lado, o altruísmo, como pró-cooperação, tem restrições diretamente
} 
Afinal, as escolhas que os indivíduos fazem, ainda que não fossem baseadas em modelos subjetivos, provavelmente, seriam divergentes entre si. É por isso que, embora não fácil, entender as mudanças no comportamento dos atores torna-se crucial para compreender a existência e a estrutura das instituições e entender a tendência de uma mudança institucional. E além disso, também justifica nosso apoio na teoria da escolha coletiva, na medida em que, a partir dela pudéssemos tentar endogeinizar as motivações dos indivíduos na tomada de decisão pró ou contra-cooperação intermunicipal, atrelado essa decisão a um determinado ambiente político-econômico, ou seja, institucional.

Lembremos que North (1990) observa os indivíduos interpretando o ambiente político-econômico em que vivem por meio do processamento de informações, as quais já existiriam em suas estruturas mentais, a partir das quais podem tirar suas conclusões sobre esse meio ambiente e, desta forma, terem condição de resolverem os problemas que estes encontram. E, ambos, a habilidade computacional dos indivíduos e a complexidade dos problemas a serem resolvidos, devem ser considerados para se entender a motivação.

Portanto, a motivação não seria apenas o comportamento maximizador que rege o indivíduo neoclássico, mas também as suas limitações, o altruísmo, o auto interesse ou restrições auto impostas, que existiriam em intensidades diversas entre os indivíduos, independentemente das escolhas que estes façam. Seriam como que variáveis exógenas, incorporadas em suas respectivas matrizes de decisão e, portanto, implicando que uma mesma decisão tomada por um grupo de indivíduos poderia ter diferentes utilidades individuais. Ou colocando de outra forma, diferentes indivíduos e, entre eles, as elites políticas municipais, poderiam ter diferentes dificuldades em se aceitar uma determinada decisão tomada pela burocracia do SUS.

Portanto, as instituições, enquanto regras segundo North (1990), podem alterar o custo dos indivíduos em razão de suas idéias, ideologias e dogmas, além do que, estas variáveis exógenas podem, freqüentemente, atuar como a "regra" principal nas escolhas individuais.

proporcionais com um número de envolvidos e com a incomplitude da informação, e, portanto, não será abordado mais amiúde neste trabalho. 
Agora, se retornarmos esta digressão lógica, especificamente, à burocracia do SUS, poderemos também encontrar indivíduos que buscam decifrar o ambiente político-econômico-institucional no qual se insere a organização, em nome da qual tomam decisões, por meio do processamento da informação possível de ser obtida, confrontando o resultado alcançado com esse processamento com algum modelo préexistente.

Isto é, provavelmente, a burocracia, não só do SUS, mas também de qualquer estrutura de cooperação, procura entender o ambiente no qual se inserem. Evidentemente, a razão seria a resolução dos problemas com os quais ela se confronta, o que, não necessariamente, a obriga a obter uma solução maximizadora, mas sim, uma solução suficientemente satisfatória para que o sistema social de produção de serviços de saúde pública oferte o mínimo esperado.

Dessa forma, também há que se reconhecer a existência de uma correlação entre o nível de conhecimento ${ }^{199}$ e de informação com a mudança institucional. Ou seja, o modo no qual o conhecimento é desenvolvido pode também influenciar as percepções das oportunidades que os tomadores de decisão têm no mundo real a seu redor. Além disso, também influenciam o modo pelo qual os indivíduos racionalizam, explicam e justificam a realidade encontrada, que por sua vez, influenciam os custos dos contratos e podem induzir a mudança institucional. Ou seja, segundo North (1990), “(...) a aquisição de conhecimento e habilidades podem modelar a direção em que ocorremas mudanças institucionais” .

E, embora as mudanças institucionais possam ser descontínuas ${ }^{200}$ ou incrementais, em geral, qualquer repactuação nas regras surge de algum tipo de

\footnotetext{
199 Segundo North (1990), pode-se entender o conhecimento de várias formas: o comunicável como sendo o que pode ser transmitido de uma pessoa para outra; o tácito que é adquirido em parte pela pratica, e em parte é pelo comunicável, e pode ser parcialmente transmitido a outros, que o adquiririam diferentemente em razão de suas habilidades pessoais; o chamado "learning by doing", ou interação repetida, pelo qual se adquire diferentes maneiras de coordenar e desenvolver rotinas; e, o chamado "path dependence", dependência do caminho, que se relaciona ao desenvolvimento de tecnologia que afeta a instituição e à forma com que elas mudam, ou seja, desenvolvido um padrão tecnológico, outros padrões e tecnologias alternativas podem ser deixadas de lado ou ignoradas, na medida em que a inicial condicione as alterações institucionais numa particular trajetória.
}

200 Segundo North (1990), serão descontinuas quando a mudança for radical nas regras formais, usualmente como resultado de conquista, revolução, guerra ou desastre natural. Serão incrementais 
descontentamento de um dos envolvidos, ou mesmo, de um grupo deles. Portanto, uma reestruturação institucional poderia ser utilizada para se resolver uma dada crise política.

Assim sendo, após a criação do SUS na Constituição Federal de 1988, que poderia ser considerada uma mudança descontínua, qualquer mudança incremental subseqüente em sua normatização não deveria implicar na alteração do todo, ou de uma parte substancial do contexto institucional, a ponto de estabelecer novos procedimentos e compromissos entre os envolvidos. Ou seja, sem por em risco a existência institucional do SUS, qualquer mudança incremental poderia ocorrer conquanto implique que os envolvidos refaçam os acordos entre si, restringindo-se à captura de algum novo ganho em potencial a partir de um objetivo comum.

E, se o objetivo comum é o acesso universal ao serviço de saúde pública, prestado com padrões mínimos de qualidade, então, um possível ganho de eficiência em potencial a ser capturado poderia ser encontrado na espontaneidade da estrutura de cooperação intermunicipal, na medida em que esta, quanto mais espontânea for, mais próxima deveria estar da qualidade esperada pelos grupos de consumidores-eleitores dos Municípios envolvidos.

Ressalte-se que a estrutura institucional não evolui com a necessária velocidade no sentido de fornecer os códigos e as regras para a resolução de todas as disputas e conflitos entre os envolvidos. Portanto, os possíveis ganhos potenciais podem não se realizar conforme o interesse de algum dos envolvidos, podendo resultar em sub-coalizões e conluios.

E, até talvez por isso mesmo, se deva reforçar a necessidade de regras que permitam suficientes mudanças incrementais em contextos institucionais, a fim de solucionar novas barganhas e compromissos entre os envolvidos, ou então, a previsão da mediação externa para a solução de conflitos, tal qual abordado no capitulo anterior.

Afinal, o que seria de se esperar é que a ausência de regras de adaptação institucional ou, de instituições que possam intermediar a resolução de conflitos, pode

quando as partes de um contrato não o quebram, mas mudam uma ou mais regras para capturar alguns ganhos potenciais excedentes (para uma ou ambas as partes), sem que necessariamente ocorra a repactuação. 
levar a uma mudança descontínua, quase sempre precedida por uma ruptura institucional. No entanto, é interessante observarmos o paradoxo encontrado em North (1990) em que a ruptura de uma instituição tem o efeito desejado dela quando em vigor, ou seja, com a ruptura institucional “(...) quase sempre se espera dos envolvidos um comportamento ideológico que minimize o oportunismo deles, uma vez que a ruptura pode implicarnuma nova configuração institucional, na descontinuidade dos contratos existentes, e na definição de novas regras" .

Obviamente, as mudanças incrementais não estariam relacionadas a alterações nos comprometimentos ideológicos e, portanto, neste caso, os envolvidos se restringiriam, provavelmente, a alterar a estrutura institucional existente apenas pela adaptação de algumas de suas regras.

North (1990) também nos chama a atenção para o fato de que a mudança institucional pode também afetar, relativamente entre os envolvidos, os custos de transação e o poder de barganha de cada um deles. Afinal, cada elite política tem diferentes modelos subjetivos e, portanto, fariam diferentes escolhas políticas, na medida em que possuam diferentes histórias passadas e uma assimetria informacional sobre as conseqüências de suas respectivas decisões. Ainda assim, embora as decisões não sejam as mesmas, não seria ilógico, com o constante ajuste incremental, esperarmos que a tendência na tomada de decisão das elites políticas seja convergente a um determinado enfoque comum. Portanto, ocorrendo a convergência na tomada de decisão pode-se inferir a ampliação das interelações dos envolvidos e do seu grau comprometimento com aquele enfoque em comum, facilitando a tomada de decisão pró-cooperação entre elas.

Finalmente, é interessante ressaltar a partir dos capítulos anteriores que, quando um conjunto de regras é imposto a dois Municípios diferentes, apesar do conjunto dessas regras ser o mesmo, o mecanismo de coerção, a forma como a coerção ocorre, as normas de comportamento e, os modelos subjetivos dos personagens são diferentes. Logo, tanto as estruturas de incentivo, quanto as conseqüências percebidas da política pública de saúde implantada espontaneamente na região pela coalizão, ou eventualmente induzidas pelo SUS, também deveriam ser diferentes. Portanto, devemos esperar que a imposição de um mesmo conjunto de regras leve a resultados 
divergentes dos esperados, mesmo entre aqueles Municípios que se pretendam envolvidos em cooperação.

\section{4. o SUS e os Municípios envolvidos num ambiente político-institucional}

Vimos a "hierarquia pública" como a provável forma mais adequada de estrutura de coordenação da política pública de saúde e, vimos que esta "hierarquia" se associa ao conceito de Estado. Por outro lado, falar em Estado envolve também se falar dos respectivos governos, os quais, enquanto entes inseparáveis de nossa realidade, são também imperfeitos.

Tanto é verdade que o funcionamento de um governo resulta de um processo político contínuo que evoluí no tempo, além de ser dependente da história. E entre os vários processos políticos, temos o da saúde pública que se pretenda instalar num determinado país, processo este que pode ser visto como um jogo entre a União (principal), que tenta afetar a ação dos vários executores, e os Municípios (agentes).

De maneira geral, o equilíbrio resultante não será maximizador pois, como já observamos, qualquer tentativa de se encontrar ou identificar um sistema ótimo, a partir de um processo político, está fadada ao fracasso. Até porque, embora seja óbvio, chamamos a atenção ao fato de que não há como se aferir se o resultado geral de uma dada forma de organização é, seguramente, superior a qualquer outra que se possa ainda ser idealizada.

Talvez, até em razão disso, como se observa nas entrelinhas do primeiro capítulo, o tradicional enfoque da análise da política econômica tome o processo político como uma questão exógena e, a partir disto, defina critérios para a avaliação de desempenho econômico sem preocupações sobre como o governo vai funcionar depois de sua implementação, quando então, costumam insurgir com várias restrições à sua ação e à confirmação da relevância das limitações informacionais dos executores da política adotada. 
Ou seja, o enfoque tradicional ${ }^{201}$ não considera que possam existir falhas políticas assim como existem as falhas de mercado, na medida em que as falhas políticas estejam enraizadas nos mesmos problemas informacionais (informação assimétrica e incompleta) observáveis nos vários setores que influenciam o processo político, tais como: a burocracia do executivo e suas agências, o legislativo, as várias ações de grupos de interesse, a mídia, e outros. E, nem tão pouco, considera os custos decorrentes da correção de tais falhas.

Com isso, o enfoque da escolha publica e, em especial, o da teoria dos contratos, ganhou destaque neste trabalho como instrumento de analise teórica das questões que envolvam o processo político, embora, continue avaliada com base em atos de política individual.

A razão desta inicial digressão lógica visa enfocar o contrato público, o qual, assim como o privado, seria também incompleto. Afinal de contas, ele também não traduz as regras e procedimentos a serem seguidos em todas as instâncias com precisão; deixando alguns pontos para serem interpretados e, até mesmo, a serem determinados futuramente.

O porque disso está na inabilidade das elites políticas, em geral, de prever todas as possíveis contingências e, na complexidade em se especificar todas as regras, ainda que todas as contingências pudessem ser previstas. E isso, sem se falar na dificuldade que as elites políticas têm em detectar objetivamente as contingências de forma que os procedimentos que elas especificam, pudessem ser postos em ação por elas mesmas.

Além disso, instituições e regras devem ser vistas como inseridas em um mundo real, complexo e, em transformação. Um mundo que constantemente procura por procedimentos voltados a responder às contingências imprevistas. É por isso que o processo político deve ter uma perspectiva evolucionária e flexível; ou seja, deveria ser entendido como algo que se desenvolve em tempo real, na medida em que a forma que

\footnotetext{
201 Com relação ao enfoque normativo (advindo da teoria tradicional), Dixit (1996) elabora um contraponto com o enfoque contratualista (advindo da teoria dos contratos), afirmando que este último “(...) possibilita que cada ato político seja visto não como uma escolha voltada para a maximização de uma função de bem estar social, mas sim, como um episódio ou movimento de jogo, dentro de um
} 
as regras assumem se correlacione com a forma com que os atos individuais são praticados.

Afinal, a força coercitiva das regras pode se desgastar com as constantes reinterpretações, enquanto os atos das elites políticas podem criar fatos e, até mesmo, novas instituições. Nestas condições, Dixit (1996) prossegue afirmando que “(...) $o$ referencial de analise necessário para a compreensão do processo de definição política deve ser o mais flexível possível, dinâmico em si mesmo e evolucionário” .

Devemos também reconhecer que diferentes decisões políticas, sejam elas regras ou atos, têm diferentes graus de performance, da mesma forma que também devemos admitir que existem diferentes graus de liberdade para a criação de regras em razão das circunstancias em que o processo político se encontra num dado tempo.

A consequiência é o reconhecimento de que a criação de regras ou normatizações é um processo, um jogo dinâmico, do qual as condições de mudança futura são incertas e mutáveis. Afinal, em ralação à condição inicial, essas mesmas regras podem ser ajustadas de modo a se atingir resultados mais favoráveis, dado que as situações novas para a sua aplicação, nem sempre são previstas.

Nesse aspecto temos o SUS, que com o passar do tempo e, até com um certo dinamismo, tem empreendido constantes alterações em sua normatização voltada às políticas públicas de saúde, nitidamente migrando de um conceito de padronização dos serviços municipais para o de regionalização.

\section{5. o contrato público e a sua credibilidade}

Vimos no último capitulo, que também há outros aspectos do processo político que se alinham com os custos de transação, tais como a informação imperfeita e consistência do tempo da ação, os quais afetam o resultado do processo durante a interação das elites políticas. Em especial, quanto ao aspecto consistência do tempo da ação, se tomássemos a estrutura de cooperação na forma de uma coalizão

conjunto de regras e instituições existentes, mas, permitindo a adoção de movimentos estratégicos capazes de afetar ou alterar regras e instituições futuras" . 
intermunicipal como um sistema social de produção, estaríamos nos referindo à credibilidade dos compromissos políticos assumidos pelas elites envolvidas quando se consideram as suas decisões tomadas ao longo do tempo.

Já quanto aos aspectos de informação incompleta, evidentemente, não podemos deixar de chamar a atenção aos problemas de agência observados, que constituem outra classe de custos de transação, envolvendo o risco moral e o oportunismo, além dos custos de se mitigar ou controlar os possíveis riscos contratuais.

Estas observações estão sendo feitas com o fito de se ressaltar que a teoria dos custos de transação deve também ser incluída entre as ferramentas de análise dos processos políticos. Ou seja, não deveríamos nos restringir ao desenho de um contrato político, como tratado no segundo capítulo, cingindo-nos apenas à promessa de uma política (ou programa) em troca de votos (ou contribuições). Afinal, os contratos públicos resultantes da interação entre entes federativos, como os que veremos amiúde mais a frente quando falarmos do modelo de regionalização empreendido pelo SUS a partir de 2000, são muito mais difíceis de se fazerem cumprir (coerção) e mais complexos que os de mercado, podendo, inclusive, variar essa dificuldade em razão da estrutura adotada para a cooperação.

Ou seja, a arquitetura contratual de uma estrutura de cooperação, abordada no capítulo anterior, guarda correspondência com forma que se pretende a essa estrutura. Colocando de outra forma, na medida em que a cooperação intermunicipal ganhe em espontaneidade, a tendência é a formatação de uma arquitetura contratual em que os Municípios envolvidos se correlacionam apenas com uma personalidade criada por eles para a consecução de um objetivo comum, que, no presente caso, se personifica numa coalizão intermunicipal. Por outro lado, quanto mais induzida for a cooperação, com maior probabilidade a arquitetura contratual se torna mais complexa, com contratos públicos sendo firmados para cada interação jurisdicional, criando uma estrutura de cooperação na forma de múltiplos convênios contratuais intermunicipais numa dada região, a qual prescinde de personalidade jurídica.

De qualquer forma, os personagens de um contrato político de uma coalizão intermunicipal tratado nos capítulo segundo e terceiro, embora de direito entre entes federativos, são de fato entre os grupos de consumidores-eleitores de um lado e as 
respectivas elites políticas municipais (indivíduos ou partidos) do outro lado. E essa é uma das características dos contratos políticos, que marcantemente os diferenciam dos contratos de mercado, ou seja, raramente se consegue identificar claramente os reais personagens envolvidos.

Talvez por isso mesmo, os termos de um contrato público são geralmente muito vagos, deixando muito espaço para interpretações. Nesses contratos os limites de autoridade costumam não ser claros, com ambas as partes podendo influenciar as ações da outra. E, além disso, esta situação pode ser encontrada, quer seja na cooperação estruturada como coalizão espontânea, quer seja no convênio induzida.

Segundo Dixit (1996), a coerção de um contrato público, em geral, está associado à ameaça de uma "força subjacente" e, que, segundo este autor, esta força poderia ser exercida, implícita ou explicitamente, por alguma mídia atuante e formadora de opinião, ou mesmo, alguma instituição que exerça a função de regulamentadora da política pública ou, que exerça o seu controle social e, portanto, assegurando a continuidade do compromisso das elites políticas depois que a posição dos consumidores-eleitores é revelada no escrutínio a partir de incentivos propostos pelas promessas de campanha.

De qualquer forma, segundo Dixit (1996), há pelo menos três mecanismos que permitem às elites políticas estabelecerem credibilidade aos contratos políticos. Um primeiro são as próprias ações tomadas pela elite política que podem persuadir os grupos de consumidores-eleitores de que ela agirá de uma certa forma no futuro, podendo, às vezes, representar aos grupos que alinhar sua decisão coletiva com a proposta da elite política é a escolha ótima ou mesmo a única opção disponível.

Um segundo mecanismo é o chamado de delegação. Com este mecanismo reduz-se nos grupos de consumidores-eleitores a o grau de mobilização de uma decisão coletiva futura, pois delegam a um grupo de representantes o poder de executar essa ação em seu nome dada a amplitude do mandato conferido. Observe-se que não se dispensa o monitoramento, pois, quando da execução da ação delegada, o representante, ou grupo deles, podem ter preferências diferentes dos consumidores-eleitores.

O terceiro mecanismo é a repetição e a reputação. Pelo enfoque de que a repetição das ações constrói uma reputação levando ao aumento da credibilidade, Dixit 
(1996) também associa esse mecanismo à idéia de construção de uma cooperação quanto maior fosse o horizonte de relacionamento das elites municipais regionais, quanto mais as necessidades de cada Município se identifiquem com os objetivos comuns regionais, quanto mais rápidas as elites políticas municipais identificarem entre si complementaridades em outras políticas públicas e, quanto maiores forem os ônus políticos pelo não esforço de proporcionar o beneficio esperado pelos respectivos grupos de consumidores-eleitores.

Talvez, entre os três mecanismos mencionados, o da reputação seja o mais interessante de o SUS perseguir, na medida em que, regulamentada a ação cooperativa dos Municípios, a sua repetição os induza a se adotarem comportamentos convergentes, dada a possibilidade de otimização dos recursos regionais e, da melhoria da qualidade do serviço prestado, aproximando-a do esperado pelos respectivos grupos de consumidores-eleitores.

Afinal, se a interação das elites políticas municipais se tornasse repetitiva, cada uma delas poderia se beneficiar adquirindo e preservando uma reputação para suas próprias ações futuras perante seus respectivos grupos de consumidores-eleitores. Com isso, a reputação teria o efeito adicional de minimizar as assimetrias informacionais com a repetição das ações, inclusive, com benefícios à burocracia do SUS, pois, sendo as informações incompletas, qualquer das elites políticas envolvidas poderia, a partir de sua reputação, sinalizar suas preferências na condução da política pública de saúde.

Se assim fosse, Municípios cujas elites políticas tenham estabelecido reputações e/ou repetições de ações de saúde publica suficientemente freqüentes, estariam minimizando às demais, a possibilidade de riscos oportunísticos na medida em que pudessem ampliar a credibilidade de seu comprometimento futuro com alguma forma de estrutura de cooperação intermunicipal.

Ou seja, a indução à cooperação intermunicipal, além dos benefícios intrínsecos à qualidade da prestação de serviços públicos de saúde, pode também conferir à burocracia do SUS, a mitigação de um de seus problemas: a assimetria informacional, além de ampliar a sua capacidade de coordenação. 


\section{3. um breve resumo do setor de saúde pública no Brasil}

No Brasil, o serviço de saúde publica se desenvolveu ao longo do século XX por intermédio de uma malha de agências públicas e organizações privadas. Entre estas se destacam o Ministério da Saúde e as Secretarias de Saúde estaduais, ambos criados em 1953; e o Ministério da Previdência e Assistência Social, por meio do Instituto Nacional de Assistência Médica da Previdência Social (INAMPS), criado em 1967. Em 1971, o INAMPS, um organismo prestador de serviços por meio de uma estrutura própria (policlínicas e hospitais), agregou a atividade de agência administradora de convênios e repassadora de recursos da Previdência Social para o setor privado da medicina, através do pronto ressarcimento ao setor privado pelos atendimentos realizados. Porém, concomitantemente ao acesso da população aos hospitais privados com tecnologias mais avançadas, também ocorreu um processo de deterioração dos serviços prestados pelo INAMPS.

Em conseqüência, criou-se em 1982, o "Plano de Reorientação de Assistência à Saúde", no âmbito da Previdência Social, que tinha como pontos principais: prioridade à atenção primária e aos cuidados ambulatoriais; eliminação da capacidade ociosa do setor público; administração descentralizada dos serviços; reconhecimento da participação complementar do setor privado na prestação de serviços médicohospitalares; e a implantação gradual da reforma do sistema.

Esse processo de reorientação evoluiu para a criação dos Sistemas Unificados e Descentralizados de Saúde-SUDS, sob administração das Secretarias de Saúde estaduais, a partir de 1986. A criação do SUDS fortaleceu a municipalização da saúde publica, ao permitir que as Secretarias Municipais de Saúde e as respectivas prefeituras se tornassem responsáveis pela operacionalização e execução orçamentária dos recursos financeiros repassados ao SUDS estadual, assim como sua aplicação para melhorar os recursos de saúde da região.

Estes princípios descentralizadores passaram a ser o ideário de um movimento conhecido como Reforma Sanitária, que teve bastante influência sobre os capítulos de saúde da Constituição de 1988, com a criação do Sistema Único de Saúde 
(SUS), que viria servir de base legal para implantação de sistemas de saúde congregando regionalmente Municípios com características e interesses afins.

Mas a realidade brasileira tem mostrado que os Municípios têm sua autonomia bastante restringida, já que dependem quase sempre de repasses de verbas originadas no nível federal e estadual. A nova Constituição, de 1988, procurou aumentar esta autonomia, através de reforma fiscal e administrativa, para aumentar os recursos financeiros disponíveis dos Estados e Municípios; em contrapartida à nova repartição constitucional de responsabilidades em 1988 no setor de saúde publica, conferindo aos Municípios e Estados maior liberdade para formular as políticas que lhes são necessárias nesse setor.

Segundo Brasil (2002b), um passo significativo para o cumprimento da diretriz constitucional de construção do Sistema Único de Saúde com direção única, em cada esfera de governo, foi a transferência do Instituto Nacional de Assistência Médica da Previdência Social (INAMPS) do Ministério da Previdência e Assistência Social (MPAS) para o Ministério da Saúde. Esse ato teve efeito com a publicação do decreto n. ${ }^{\circ}$ 99.060, de 7 de março de 1990, antes, portanto, da promulgação da Lei n. ${ }^{\circ}$ 8.080, que só ocorreu em setembro do mesmo ano.

Assim, o Ministério da Saúde iniciou a implantação do SUS tendo o INAMPS como base do novo sistema. O INAMPS foi extinto pela Lei n. ${ }^{\circ} 8.689$, de 27 de julho de 1993, quase três anos após a promulgação da Lei Orgânica da Saúde (8.080/90), cujo artigo primeiro estabelecia que: “As funções, competências, atividades e atribuições do INAMPS serão absorvidas pelas instâncias federal, estadual e municipal gestoras do Sistema Único de Saúde, de acordo com as respectivas competências, critérios e demais disposições das Leis $n{ }^{\circ} 8.080$, de 19 de setembro de 1990, e n. ${ }^{\circ} 8.142$, de 28 de dezembro de 1990” .

De qualquer forma, o SUS, ao incorporar o INAMPS, acabou por preservar também a sua lógica de financiamento e de alocação de recursos financeiros. Dessa forma, o SUS iniciou sua atuação na área da assistência à saúde com caráter universal, mas, utilizando-se de uma instituição que tinha sido criada e organizada para prestar assistência a um segmento específico da população. 
Isso explicaria o porque do SUS, em seu início, estabelecer limites físicos e financeiros para as unidades federadas, já que era essa a lógica embutida nos procedimentos do INAMPS. Ou seja, o SUS não adotou de imediato uma lógica própria no financiamento a assistência à saúde voltada a toda a população, que implicasse numa maior eficiência alocativa dos recursos voltados à prestação de serviços públicos entre os Estados, ainda que provocasse uma reação política dos Estados mais desenvolvidos e que contavam com uma maior proporção de recursos.

Porém, a manutenção do INAMPS no período inicial do SUS e, portanto, a permanência de sua lógica de financiamento não evitou que, a partir de maio de 1993, o Ministério da Previdência Social deixasse de repassar recursos da previdência social, rompendo com o vínculo entre a nova responsabilidade constitucional com a política pública de saúde e a disponibilidade orçamentária.

Essas dificuldades orçamentárias perduraram, segundo Brasil (2002b), pelo menos até 1994; sendo que, somente a partir de 1998, as normas do SUS, emitidas pelo Ministério da Saúde passaram a buscar uma distribuição mais equiitativa dos recursos entre os Estados da Federação. Mais recentemente, a projeção dos recursos financeiros destinados às políticas de saúde pública acabou sendo significativamente ampliada com a promulgação da Emenda Constitucional n. ${ }^{\circ} 29$, em 2001, ao mesmo tempo em que a burocracia do SUS migrava do modelo predominantemente descentralizador das ações de saúde pública para o modelo descentralizador regionalizado, sinalizando com incentivos à formação de estruturas de cooperação intermunicipal por meio de convênios.

\section{1. o ambiente constitucional do setor saúde}

A Constituição do Brasil impõe o regime federativo em seu artigo $1^{\circ}$ : “ $A$ República Federativa do Brasil, formada pela união indissolúvel dos Estados e Municípios e do Distrito Federal, constitui-se em Estado Democrático de Direito e tem como fundamentos: (...)” . Esse modelo revela a existência de um sistema federativo diferente do clássico dual, e constitucionalmente garantido como "clausula pétrea" 
através do artigo $60, \S 4^{\circ}$, inciso I. O nosso ponto de análise pauta-se nas definições de centralização, descentralização e desconcentração, todas inerentes ao federalismo; sobretudo no caso brasileiro, onde se consagram três níveis, isto é, um Estado Federal composto por três entes: União, Estados e Municípios.

Tal situação se caracteriza pela repartição de competências privativas e pelas autonomias político constitucional, organizacional e financeira. Sempre se tem associado autonomia ao Federalismo, principalmente, no que diz respeito à repartição de competências tributárias; e, com isso surge a questão central: competência tributária "versus" competência concorrente, resultante da atribuição constitucional à União da emissão das normas gerais tributárias (artigo 146 da CF 88). Essa atribuição tem favorecido o caráter centralizador da União por meio do exercício desta competência legislativa; sendo, portanto, nosso interesse situar a verdadeira condição dos Municípios diante o modelo de federalismo brasileiro estruturado pela Constituição de 1988.

Diz o parágrafo único do art. $1^{\circ}$ da CF 88: “Todo o poder emana do povo, que o exerce por meio de representantes eleitos direta ou indiretamente, nos termos desta Constituição” . Ou seja, embora se estabeleça que o poder é uno e indivisível quanto a sua origem, nada impede que a sua manifestação seja diversificada. Esse movimento do centro para a periferia é chamado de descentralização política, implicando, ao invés de uma única ordem jurídica de um Estado central, a adoção de diversos níveis e órgãos de competência; de tal sorte que, a forma de Estado adotada é uma questão de grau de centralização ou descentralização. Reis (2000, p. 22) esclarece: “O que marca o conceito de descentralização é a idéia de uma estrutura plural de exercício do poder político, conduzido a uma ordem jurídica única, mas pluralista, uma vez que a manifestação política do Estado dá-se, (...), pela capacidade para criar o direito e para organizar as instituições políticas (...). Assim a descentralização política define uma pluralidade de ordens jurídicas, ordenando-se e coordenando-se numa estrutura total, conformada por ordens jurídicas parciais acopladas harmoniosamente e complementarmente” .

Ainda há que se fazer uma distinção entre descentralização e desconcentração. Pelo primeiro têm-se uma diversidade de entes federativos, 
autônomos, dotados de personalidade jurídica, todos com competência para o desempenho da função política, administrativa e legislativa. Quanto ao segundo termo trata-se da atribuição a um órgão qualquer de capacidade para a prática de uma determinada ação, sem que se configure em autonomia no exercício da competência. Portanto a descentralização configura-se na repartição do poder de decisão entre os entes federativos, respeitados seus territórios de domínio, poder este incidente sobre questões organizacionais, político administrativas, e, sobretudo, financeiras e tributárias. Daí tratar-se o Estado Federal e/ou o federalismo, como "sinônimos" de descentralização do poder; devendo-se, no entanto não se confundir o Estado Federal com os Estados Autônomos, para os quais se atribui inclusive a autonomia constitucional.

Posicionadas as definições, passamos propriamente dito ao ambiente constitucional no qual se desenharam as diretrizes e os fundamentos que estruturaram o Sistema Único de Saúde-SUS.

No período que antecedeu à formação da Constituinte de 1988, segundo Abrucio e Costa (1998, p.111), “as políticas sociais no Brasil eram administradas e financiadas de forma mais ou menos centralizada por órgãos e agências do Governo Federal, como o INAMPS e a Fundação Nacional da Saúde (FNS), (...). Embora as políticas sociais desse modelo tivessem como objetivo final a universalização dos serviços básicos (...), exerciam, na verdade, uma função complementar: de um lado, a provisão de bens ofertados no mercado, cujo acesso era restrito a uma pequena parcela das classes médias e da burguesia; de outro, os privilégios garantidos pelo Estado aos servidores públicos, (...), e trabalhadores do setor privado, vinculados à estruturas sindicais corporativas” .

Segundo esses autores, a grande maioria dos setores, entre eles o da prestação de serviços públicos de saúde, se não plenamente incorporados nos mecanismos da "cidadania regulada" por um governo centralizador, acabavam por caracterizar sua atuação entre a “(...) dependência clientelista tradicional e as estruturas assistencialistas massificadas e burocráticas na periferia dos centros urbanos” . No entanto, a característica assistencialista se manifestava inclusive naquelas políticas fortemente centralizadas pelo Governo Federal, tais como a da Previdência Social, por 
meio da atribuição de cargos estratégicos a gestores indicados pelos níveis regionais e locais.

Porém, quando essas políticas ganham contornos mais centralizadores no período dos governos militares, provoca-se a redução da influência de oligarquias regionais e locais. Além do mais, as atribuições das esferas de governo, em especial, na área da saúde publica, não “(...) estavam claramente estabelecidas e, de modo geral, observa-se a existência de competências concorrentes, que davam lugar a redes (estruturas) paralelas de serviços, bem como a ausência de planejamento e, correlatamente, de políticas coordenadas de saúde” (Viana, 1994).

Observe-se que não somente as políticas do setor de saúde publica, mas também qualquer das políticas sociais, ao longo desses períodos, variando em grau, operavam através da formação de "estruturas" envolvendo desde a burocracia e políticos do Governo Federal até os grupos de poder regional e local. Estes últimos executavam seus programas por intermédio de suas Secretarias, ou simplesmente intermediavam a alocação dos recursos financeiros e materiais junto às entidades filantrópicas, religiosas ou leigas, tais como as Santas Casas.

Além de privilegiar o atendimento individual hospitalar e especializado em detrimento das ações coletivas de promoção de saúde pública e de prevenção de doenças; outras críticas a este sistema centralizado podem ser elencadas: o privilégio ao setor privado e especializado na prestação de assistência médica, onerosa e de baixo impacto no incremento da qualidade de saúde da população, a dificuldade de controle das contas e dos gastos, já que os hospitais relacionavam-se diretamente com a instância federal num país com dimensões continentais, o paralelismo de ações entre os diversos órgãos vinculados à saúde (Heimann, 1998).

Devido a manutenção dessa estrutura, mesmo no período que se segue ao encerramento do regime militar, forma-se um ambiente político nacional polarizado pelos que colocavam conceitos de democracia e descentralização de um lado, contra o autoritarismo e a centralização, de outro.

Este comportamento resultou numa "operação desmanche" ao longo dos anos 80, uma "descentralização selvagem" de políticas sociais, ratificada politicamente com a eleição dos governadores em 1982. Isso ativou uma postura federativa de caráter 
competitivo e não cooperativo, num ambiente em que o Governo Federal, enfraquecido tanto política quanto financeiramente por uma crise fiscal, passa a se envolver cada vez menos, afetando os serviços públicos prestados.

$\mathrm{Na}$ verdade autores políticos não descartam a hipótese de que os governadores e prefeitos poderiam estar pretendendo garantir o máximo de recursos fiscais possíveis, desvinculados de qualquer área social específica, conferindo ao Governo Federal a imagem de provedor desses serviços sociais diante de seus eleitores; de tal forma que, esta situação desencadeasse, de um lado, tanto uma reavaliação do conceito da autonomia local como solução universal para a desigualdade social e econômica, quanto uma revalorização do papel dos governos federal e estadual, não apenas no financiamento, mas também sob o aspecto de coordenação, planejamento e assistência técnica, do outro lado.

Enriquece essa hipótese, a aplicação da lógica "predatória” do federalismo fiscal brasileiro, a qual se baseia nas “(...) barganhas federativas, pelas quais cada nível de governo pretende transferir a uma outra administração a maior parte dos custos políticos e financeiros da gestão das políticas e reservar a si a maior parte dos benefícios dela derivados” (Arretche, 1998).

Deste modo, os principais problemas do sistema centralizado e descoordenado de políticas de saúde pública podem ser divididos entre o paralelismo das ações de saúde entre as diversas estruturas formadas e órgãos vinculados e, portanto, a fragmentação administrativa, e, a excessiva centralização do poder decisório no ente federativo União. Tais problemas impuseram uma nova postura federativa no âmbito do setor de saúde publica: a clara definição de atribuições e responsabilidades, na qual cada nível federativo exerceria funções diferenciadas e exclusivas na gestão desses serviços. E, foi este o ambiente que se refletiu na Assembléia Constituinte de 1988.

Se visualizarmos a Assembléia Constituinte de 1988 como uma arena, na qual se travou um embate político entre dois grupos favoráveis à descentralização, mas, divididos entre si, de um lado os que desejam a manutenção do modelo assistencialista e clientelista, e de outro os chamados setores "progressistas" articuladores de políticas sociais modernizadoras e universalistas, e, não nos preocupando em aqui ocupar espaço 
na definição mais precisa da composição desses grupos, então poderemos, a partir das acomodações das vontades políticas oriundas desse confronto, inferir as motivações que resultaram no desenho da Constituição de 1988, no que tange aos aspectos de saúde pública.

A Constituição de 1988 trouxe em seu bojo a revisão do sistema de saúde brasileiro com a identificação de algumas regras de acesso às ações e serviços de saúde. Essas regras determinam o direito à cidadania, estabelecem que as ações organizacionais devam ser focadas no atendimento universal e, orientam que a formulação dos critérios de racionalização político-econômica do sistema de saúde devam ser compatíveis com a relação existente entre os custos avaliados do confronto de duas análises: a forma de se financiar sua implementação, "versus", o grau de aceitação desse sistema pela sociedade como um todo.

Textualmente, a Constituição de 1988 define que a "saúde é direito de todos e dever do Estado, garantido mediante políticas sociais e econômicas que visem à redução do risco de doenças e de outros agravos e ao acesso universal igualitário às ações e serviços para sua promoção, proteção e recuperação” （art. 196, CF 88).

Em seu conjunto de regras, a Constituição Federal reconhece a existência do Sistema Único de Saúde (SUS) ao estabelecer que "as ações e serviços públicos de saúde integram uma rede (estrutura) regionalizada e hierarquizada e constituem um sistema único, (...)” . Esse sistema único recebe a atribuição constitucional de gestar e normatizar a ofertar de "ações de promoção, prevenção, cura e reabilitação" （art. 198, CF 88).

Além disso, a Constituição Federal de 1988, quando se refere ao SUS, complementa o seguinte: que ocorra o deslocamento do poder decisório do centro para a periferia, caracterizado pela "descentralização, com direção única em cada esfera de governo".

Hoje tal deslocamento é conhecido por municipalização da saúde, no qual se propõe a ampliação da responsabilidade municipal, reforçando-se sua autonomia (inciso I, art. 198, CF 88), conjugada com o conceito da universalidade em sua diretriz de "atendimento integral, (...)” , por meio do qual os serviços de saúde pública não mais se restrinjam aos trabalhadores formalmente inseridos no mercado de trabalho e 
seus dependentes, mas que sejam acessíveis a todos (inciso II, idem). A Constituição Federal também tece como regra para as tomadas de decisão no âmbito da saúde pública, a "participação da comunidade" (inciso III, idem).

A Constituição Federal em seu artigo 200 também relaciona uma série de atribuições conferidas ao SUS, que devem ser regulamentadas por Lei Complementar. São elas as seguintes: “controlar e fiscalizar procedimentos, produtos e substâncias (...)", "executar as ações de vigilância (...), bem como as de saúde do trabalhador", “ordenar a formação de recursos humanos (...)”, "participar (...) das ações de saneamento básico”, "incrementar (...) o desenvolvimento científico e tecnológico”, "fiscalizar e inspecionar alimentos (...) para o consumo humano”, “(...) controle e fiscalização (...) de produtos psicoativos, tóxicos e radioativos" e, “colaborar na proteção do meio ambiente, (...) e do trabalho” .

\section{2. o reflexo da mudança de direção do vetor do debate político}

No intuito de se atender ao preceito constitucional da universalização e democratização das políticas sociais, é conferida pela Constituição Federal à União a capacidade de legislar as chamadas normas gerais, em complemento ao texto constitucional. Com isso, estabelecem-se vínculos da União com a sociedade como um todo, por meio de uma legislação complementar, dentre a qual, quando referenciada ao âmbito do setor de saúde publica, é conhecida por Lei Orgânica da Saúde. No entanto, devemos manter em mente que toda essa legislação complementar surge em reflexo à mudança no sentido do conflito político existente, não mais entre centralização "versus" descentralização, mas entre dois modelos de descentralização, manifestados na arena da Assembléia Constituinte.

Assim sendo, podemos manter em nosso desenho do ambiente político institucional, o enfoque de duas correntes políticas imersas numa arena política pela capacidade de influenciar na legislação complementar à norma constitucional vigente, aqui em especial, a do âmbito da saúde. Portanto, se admitido de um lado os grupos pró-manutenção do modelo assistencialista, oriundos do clientelismo, e de outro os 
progressistas, articulados em torno do ideal de modernização e universalização das políticas sociais de saúde, poderíamos inferir como uma das gênesis do SUS na Constituição Federal de 1988, a resultante de um conflito político entre a centralização com sua burocracia no nível federal, e a descoordenação e clientelismo nos demais níveis federais de saúde.

Porém, há que se ressaltar que já em 1982, com a criação do Conselho Nacional de Administração da Saúde Previdenciária - CONASP e a instituição das Ações Integradas de Saúde (AIS) através de convênios com as Secretarias de Saúde, estaduais e municipais estabelecidos entre 1984 e 1987, já se objetivava a integração e racionalização da atuação do setor público no âmbito da saúde. Tratava-se então, de uma primeira tentativa de gestão conjunta das três esferas de governo; que resultou na incorporação ao programa de cerca de 2.500 Municípios, principalmente das regiões centro e sul. No entanto, não atingiu os objetivos a que se propunha: a ampliação das ações coletivas de saúde e de prevenção a doenças.

E, além disso, ressalte-se também que, em 1987, já visando corrigir a centralização excessiva e a descoordenação dos serviços públicos de saúde, implanta-se o Sistema Unificado e Descentralizado de Saúde (SUDS), o qual a União procurou implantar aproveitando-se do discurso pró-descentralização oferecido pelos governadores, comprometendo-os enquanto pretendiam a elevação das transferências não vinculadas (Abrucio e Costa, 1998).

Com o SUDS propunha-se a "unificação descentralizada" das diversas "estruturas" formadas, ou seja, aos Estados a descentralização dos recursos físicos e a reestruturação da gestão de atendimento às ações de saúde, enquanto a União se concentraria no planejamento e coordenação, controle e avaliação das ações da "estrutura", agora como um todo.

Abrucio e Costa (1998) também chamam nossa atenção ao fato de que os Estados receberam os encargos da prestação de serviço com o SUDS sem a contra partida esperada das transferências de recursos financeiros. Tal fato, segundo esses autores, pode ter contribuído para a conclusão de um processo de descentralização constitucional, na forma do SUS, com a transferência dos serviços de saúde aos 
Municípios via barganha empreendida na arena Constituinte pelos gestores estaduais, em razão da situação então deficitária das estruturas estaduais.

Esse ambiente político descentralizador, quando tomado por variável existente e exógena no momento em que se definem as regras constitucionais de 1988, pode ter tido muita influência nas que concebem o SUS como um sistema em estrutura de serviços públicos e privados, descentralizada, regionalizada e hierarquizada. Nesse sistema, o setor privado participaria de modo a complementar as ações através de convênios ou contratos com o setor público, priorizando as instituições filantrópicas e sem fins lucrativos.

Portanto, mesmo ocorrendo uma nova partição de responsabilidades entre os entes federativos, se a articulação política entre correntes pró-centralização "versus" as pró-descentralização pouco definiram as tendências das políticas no campo da saúde, uma vez que a própria composição constitucionalista de 1988 já definia uma majoritária postura descentralizadora; então se pode concluir como natural a atribuição constitucional, ao ente federativo União, de coordenador dos mecanismos de cooperação entre os demais entes, em especial os Municípios; de tal forma que as barganhas políticas fossem empreendidas com menos custos às ações de saúde dirigidas à população e, portanto, menos vinculadas ao cálculo meramente eleitoral de seus gestores públicos.

Mesmo porque, e até por que não dizermos por "usos e costumes", permanecem as práticas políticas da criação de "estruturas" pelas quais se articulam e coordenam ações entre as três esferas federativas, envolvendo inclusive a sociedade civil e a iniciativa privada.

Ao lado disso, além de a Constituição de 1988 elevar os Municípios à condição de ente federativo (art. $1^{\circ}, \mathrm{CF} 88$ ), também se estabeleceram alguns papeis a serem desempenhados em políticas sociais de saúde pelos agora três entes federativos: confiou aos Municípios a prestação dos serviços de atendimento à saúde da população, reservando à União e aos Estados a ação de provedores de cooperação técnica e financeira.

Entretanto, logo após a promulgação constitucional, os entes federativos se confrontam com a constatação da não existência de qualquer base financeira ao SUS 
prevista na Constituição, ou qualquer outra fonte de recursos orçamentários diretamente vinculada aos serviços de saúde. Eram, na verdade, dependentes do total de recursos previstos no Orçamento da Seguridade Social, o que afetava o planejamento de sua expansão. Tal situação impôs a necessidade de uma negociação da União com Estados e Municípios a fim de se implementar a estrutura descentralizada prevista, distribuindose responsabilidades e recursos.

Cabe aqui uma ressalva especificamente sobre os Estados. Dada a redução constitucional de seu campo de ação como definidor e executor da política de saúde, restou-lhes cooperar e estimular a municipalização da saúde, levando em conta as peculiaridades locais, ao lado da manutenção de suas ações e serviços na saúde já existentes; embora seja "possível constatar que, na maioria dos Municípios, a participação dos governos estaduais no financiamento da saúde é mínima ou nula” , ressalvando "os casos em que o Estado cede funcionários para trabalhar nas redes (estruturas) municipais, embora essa contribuição seja de difícil mensuração e reflitao padrãoaleatório de cooperação entre Estadose Municípios” (Abrucio e Costa, 1998, p.125).

Como já observado, a Carta Magna também regra que "no âmbito da legislação concorrente, a competência da União limitar-se-á a estabelecer normas gerais” ( $\left(1^{\circ}\right.$, art. $\left.24, \mathrm{CF} 88\right)$. Com essa autorização constitucional, a União pode adotar comportamentos tutelares sobre os demais entes federativos, entre eles, aquele incidente no âmbito das políticas sociais que convirjam ao processo de municipalização da saúde. A característica mais marcante dessa legislação complementar é a atribuição de um papel à União, que se configura na permissão ao Ministério da Saúde de emitir Normas Operacionais Básicas - as chamadas NOB's - normatizadoras tanto dos procedimentos às ações e serviços prestados de saúde à população, em especial atribuídas aos Municípios, quanto das transferências de recursos da União aos demais entes federativos no âmbito da saúde.

Esse comportamento tutelar se reforça com o controle político e operacional das transferências vinculadas ao Sistema Único de Saúde - SUS, onde “(...) tal postura é decorrente de um processo que se inicia com a fragmentação da coalizão que estava no governo no período conhecido como Nova República (1985-1989), levando a um 
realinhamento dos atores, com o eixo se deslocando da ênfase em políticas públicas universalistas, democráticas e redistributivas, para a ênfase na focalização, seletividade e definição da articulação público-privado (...)” (Misoczky, 1999).

Dessa forma, se fez necessária a criação de um arcabouço jurídico institucional e infraconstitucional, que desse suporte às ações voltadas aos problemas detectados logo de início no SUS. Promulgou-se a chamada Lei Orgânica da Saúde, Lei n. ${ }^{\circ} 8.080$ de 1990, a qual regula os princípios constitucionais, dispondo sobre as condições para a promoção, proteção e recuperação da saúde, a organização e o funcionamento dos serviços correspondentes; são dispositivos que se vinculam à descentralização da saúde, ou seja, ao processo de municipalização. A seguir, promulga-se a Lei n. ${ }^{\circ}$ 8.142, também de 1990, que dispõe sobre a participação da comunidade na gestão do SUS e sobre as transferências intergovernamentais de recursos financeiros na área da saúde.

\section{3. a descentralização "versus" a autonomia federativa dos Municípios}

“O que deve caracterizar a descentralização no Sistema de Saúde não é só o fato de a tomada de decisão situar-se junto ao local onde os serviços são prestados e a existência de maior possibilidade de controle social sobre esse serviços. É, sobretudo, a autonomia das instâncias sub-nacionais, para exercitar sua principal competência: organizar o respectivo subsistema, de acordo comas peculiaridades locais, respeitados os demais postulados constitucionais” ; que se configuram, como já observamos, nos seguintes conceitos: universalização, acesso igualitário, regionalização e hierarquização da estrutura, direção única, atendimento integral, prioridade para as atividades preventivas e a participação da comunidade (Vianna, 1992, p. 35-36).

Na implementação das primeiras experiências de descentralização da gestão administrativa, são criadas algumas estruturas e mecanismos a serem implantados pelos Estados e Municípios que propiciariam maior capacidade gerencial. Denominam-se Conselhos de Saúde, Fundos de Saúde, planos estaduais e municipais, e relatórios de gestão. 
A Lei 8.080/90 também estabelece que as direções únicas do SUS em cada esfera de governo, previstas pela Carta Magna de 1988, devam ser exercidas através dos seguintes órgãos: "no âmbito da União, pelo Ministério da Saúde; no âmbito dos Estados e Distrito Federal pela respectiva Secretaria da Saúde; e, no âmbito dos Municípios também pelas respectivas Secretarias da Saúde ou equivalente” (art. 9, Lei 80080/90).

Dessa forma, previu-se o SUS operando em cada esfera de governo, respeitando as respectivas autonomias política e administrativa; expressas pela liberdade de cada ente federativo em estruturar seus próprios sistemas, sem subordinação a outras esferas de governo, responsabilizando-se pelas ações e serviços de sua competência nos limites do seu território; obrigando-se, no entanto, a observar os princípios e as diretrizes do SUS (art. $7^{\circ}$, Lei 8080/90, refletindo o art. 198, CF 88).

E é com base nesses princípios e diretrizes, que a Lei Orgânica da Saúde elenca as atribuições comuns e as competências de cada uma das três esferas de governo no âmbito do SUS (art. 15 a 18, Lei 8.080/90).

Além de constituir a Direção Nacional do SUS, a Lei Orgânica da Saúde atribuiu-lhe a autoridade de fixar critérios e valores para a remuneração de serviços e os parâmetros de cobertura assistencial, os quais definirão inclusive a participação complementar atribuída à iniciativa privada. Porém, restringe-se também à Direção Nacional do SUS a elaboração de tabelas de preço único, pois, a confecção de normas técnicas (que não são as normas gerais) é uma atribuição comum aos entes federativos e, portanto, nelas se incluindo o estabelecimento de padrões de qualidade e os parâmetros de custos que caracterizam a assistência de saúde (inciso V, art. 15, Lei 8.080/90).

Dessa forma, qualquer definição de um modelo padrão de contrato do SUS imposto pela União não nos surpreenderia se alguns autores o considerassem como uma ingerência deste na administração estadual e municipal; uma vez que se estabeleceu, em Lei, como competência da Direção Nacional do SUS a ação de "acompanhar, controlar e avaliar as ações e os serviços de saúde, respeitadas as competências estaduais e municipais" (inciso XVII, art. 16, Lei 8.080/90). 
A Lei Orgânica da Saúde também criou o Sistema Nacional de Auditoria no âmbito do Ministério da Saúde. Justifica-se sua existência apenas pela incumbência de verificar a conformidade dos recursos repassados a Estados e Municípios com a programação aprovada e, portanto, com a aplicação "de fato" dos recursos repassados (via parâmetros a serem regulamentados pelas NOB's). Esta é uma observação que procede da Constituição de 1988, pela qual se obrigam os Estados e Municípios a prestar contas da aplicação de qualquer dos recursos considerados em seus respectivos Orçamentos, mesmo aqueles transferidos por qualquer outra esfera federativa, ao Tribunal de Contas correspondente sem a menção de qualquer outra instituição (Municípios cf. art. 31, CF 88).

Assim sendo, os Municípios não se obrigam a prestar contas a qualquer órgão do Governo Federal, mesmo porque, a Lei, ao conferir competência à Direção Nacional do SUS de criar um Sistema Nacional de Auditoria, se expressou quanto à sua destinação, da seguinte forma: “(...) coordenar a avaliação técnica e financeira do SUS em todo o Território Nacional em cooperação técnica com os Estados, Municípios e Distrito Federal” (inciso XIX, art. 16, Lei 8.080/90) (grifo nosso).

Note-se que, mesmo na situação de se vincular a transferência dos recursos a parâmetros quaisquer estabelecidos através de convênios, acordos ou outras formas, as atribuições do Sistema Nacional de Auditoria do Ministério da Saúde se limitam a certificar a exatidão e a regularidade dos gastos, e não a de auditar outro ente federativo, o que afrontaria a autonomia constitucional.

A Lei também delega competência à Direção Nacional do SUS para “promover a descentralização para as Unidades Federadas e para os Municípios, dos serviços e ações de saúde, respectivamente, de abrangência estadual e municipal " (inciso XV, art. 16, Lei 8.080/90).

Neste ponto, abrimos um "parêntese" para tratar da questão da descentralização, inclusive considerada em uma das diretrizes constitucionais do SUS, quando trata da “(...) descentralização, com direção única em cada esfera de governo” (art. 198, CF88).

Observe-se que a Constituição não faz referência ao tipo de descentralização, da mesma forma que entre as competências constitucionais atribuídas ao SUS (art. 200, 
CF 88), nenhuma delas se vincula a qualquer ente federativo, de tal sorte que, a nenhum dos entes federativos se poderia atribuir responsabilidade constitucional efetiva pelas ações e serviços de saúde; pelo contrário, prevalece a idéia de co-responsabilidade. Isso dá aos Municípios uma certa "brecha" constitucional de desencadear as ações de acordo com os seus interesses locais, o que de certa forma até seria compatível com o princípio estabelecido logo no art. $1^{\circ}$ da Constituição Federal; pelo qual, o Município é elevado à condição de ente federativo. O problema é como financiá-las.

Por outro lado, as ações de saúde são atribuídas constitucionalmente apenas aos Municípios; ou seja, o Município é o único ente federativo a receber a incumbência constitucional específica de "prestar, com a cooperação técnica e financeira da União e do Estado, serviços de atendimento à saúde da população” ～(inciso VII, art. 30, CF $88)$.

Em meio a essa atribuição constitucional, encontramos os Municípios diante de novas responsabilidades, num momento em que muitos deles, principalmente aqueles de pequeno e médio porte, não dispunham de infraestrutura qualificada ao atendimento que se pretendia universalizado e uniformizado a toda população; nos quais, em sua maioria, “(...) as respectivas Secretarias de Saúde não existiam até meados da década de 1980” ( Misoczky, 1999). Estas dificuldades do nível local se apresentavam na forma de ausências ou deficiências, em parte ou conjugadas, de alguns dos seguintes itens: prestação de serviços básicos de saúde, treinamento de pessoal, equipamentos, estrutura organizacional e capacidade de expansão.

São limitações que sempre afetam a equidade e a eficiência dos serviços prestados entre as populações dos diversos Municípios; justificando moralmente, entre outros, que, em paralelo ao processo de municipalização da saúde pretendido, ocorresse um processo de recentralização e de redução do espaço de tomada de decisão da esfera local para a União. É em meio a esse ambiente que a União editou, como norma geral, a Lei 8.080/90; uma Lei que claramente visa, com suas disposições legais, subordinar o SUS ao ente federativo União.

Como já observado na seção anterior, a participação efetiva constitucionalmente atribuída à União junto ao sistema, praticamente a restringe à emissão das normas gerais, cabendo aos Estados complementarem as normas baixadas 
pela União a fim de atender às suas peculiaridades, e, aos Municípios, pelo interesse local, suplementá-las, de tal modo reconhecida pela norma geral, a qual "os autoriza" a normatizar "complementarmente as ações e serviços públicos de saúde no seu âmbito de atuação" (item XII, art. 18, Lei 8.080/90).

No entanto, ao interpretarmos o conceito constitucional de descentralização aplicável como incidente não só sob aspectos administrativo, técnico, mas também de aplicação dos recursos financeiros, e, conjugado-o ao conceito de autonomia constitucional dos entes federativos; percebe-se "um certo ar" de inconstitucionalidade quando a Lei 8.080/90 propõe que “o Ministério da Saúde acompanhará, através de seu sistema de auditoria, a conformidade à programação aprovada da aplicação dos recursos repassados a Estados e Municípios. Constatada a malversação, desvio ou não aplicação dos recursos, caberá ao Ministério da Saúde aplicar as medidas previstas em lei” ( $\$ 4^{\circ}$, art. 33, Lei 8.080/90).

Ou seja, com o dispositivo legal acima mencionado, independentemente da autonomia federativa pretendida pela Constituição Federal, o uso dos recursos financeiros repassados da União a Estados e Municípios e dos Estados aos Municípios torna-se plenamente vinculado a uma combinação de índices, estabelecidos conforme análises técnicas de programas e projetos, e parametrizados pela combinação de alguns critérios, tais como os que envolvam aspectos demográficos, epidemiológicos, de organização dos serviços, de nível de participação do orçamento estadual e/ou municipal no setor saúde, entre outros (caput, art. 35, Lei 8.080/90).

O interessante é que o aspecto de legalidade acaba sendo conferido por uma outra Lei, a qual ratifica que "os recursos (...) serão repassados de forma regulare automática para os Municípios, (...), de acordo com os critérios previstos no artigo 35 da Lei 8.080/90” (art. 3º Lei 8.142/90).

Essa mesma Lei, a de n. ${ }^{\circ} 8.142$ de 1990, diz que em não se regulamentando o art. 35 da Lei 8.080/90, o repasse dos recursos dar-se-á pelo seguinte critério: no mínimo metade do volume de recursos a transferir obedecerá a índices demográficos, com pelo menos $70 \%$ (setenta por cento) do volume total destinado a Municípios ( $\S 1^{\circ}$ e $2^{\circ}$, art. $3^{\circ}$, Lei 8.142/90). 
Isto criou uma situação legal que deixa margem ao Governo Federal de vincular a parte restante dos recursos financeiros a transferir, com quaisquer parâmetros que considerem adequados, podendo estes ser estabelecidos inclusive através de convênios, ampliando os pré-requisitos de qualificação para além dos previstos no $\operatorname{artigo} 4^{\circ}$ da Lei 8.142/90 (Misoczky, 1999).

Portanto, os Municípios, juntamente com os Estados e o Distrito Federal, para receberem os recursos previstos de forma "regular e automática", no mínimo “deverão contar com” (art. 4, Lei 8.142/90) vários elementos, ou seja: Fundo de Saúde, Conselho de Saúde, Plano de Saúde, Relatório de Gestão, Contrapartida de Recursos à Saúde, e com uma Comissão para Implantação de Plano de Cargos e Salários.

O interessante a se observar em particular aqui é que esse termo na lei "contar com” poderia facultar, em especial aos Municípios, a obrigação de fazê-los cumprir "de direito", e não necessariamente "de fato", já que os gestores estaduais e da União, dado o conceito de autonomia federativa, não poderiam entrar na análise de mérito quanto ao real atendimento de todos esses requisitos. Porém, a Lei, prevendo tal situação estabelece que “o não atendimento pelos Municípios, ou pelos Estados, ou pelo Distrito Federal, dos requisitos estabelecidos neste artigo, implicará em que os recursos concernentes sejam administrados, respectivamente, pelos Estados ou pela União” (parágrafo único, art. 4º Lei 8.142/90).

Além do mais, tal postura foi ratificada pela autorização legal ao Ministério da Saúde de "estabelecer condições paraaplicação desta Lei " (art. 5, Lei 8.142/90); ou seja, em a Lei 8.142/90 dispor sobre as transferências intergovernamentais de recursos financeiros na área da saúde, entre outras atribuições, criam-se as condições legais para que, no mínimo 50\% do repasse financeiro, "regular e automático", ocorra com base na prova do cumprimento de requisitos, uma vez que as transferências passam a se vincular ao exame de mérito de seu "de fato" cumprimento, o que, de certa forma, afeta a autonomia administrativa dos Municípios.

Como resultado, à margem da autonomia constitucional, a descentralização da gestão da saúde passa a envolver-se em "convênios" ou "acordos de vontades " entre as três esferas de governo, pautados na competência concorrente de cuidar da saúde, na 
não regulamentação do artigo 35 da Lei 8.080/90, e na "brecha legal” pela qual os Estados e Municípios têm sua autonomia limitada por normas condicionadoras da aplicação dos recursos financeiros transferidos do Fundo Nacional de Saúde.

\section{4. as mudanças institucionais no SUS - tendência a induzir a cooperação}

Vimos que a atribuição legal de "estabelecer condições para a aplicação desta Lei”, constante no art. $5^{\circ}$ da Lei 8.142/90, ao Ministério da Saúde representa, além de um movimento de recentralização, também uma autorização legal à formulação e implementação de diversas Normas Operacionais Básicas, as chamadas NOB's, das quais passamos a falar mais amiúde.

\section{1. a institucionalização e as mudanças no modelo de descentralização (NOB`s)}

Dentre os objetivos traçados pelas NOB's, aparece implícito, comum a todas elas, a intenção de que os Municípios atuem com o máximo de autonomia financeira e gerencial, mas, dentro dos princípios gerais estabelecidos pela legislação constitucional e infraconstitucional e claramente detalhadas por toda uma série de NOB's.

Ou seja, além das Normas Operacionais Básicas destinam-se à distribuição de responsabilidades entre os Estados e Municípios, também se destinam a induzir a capacitação, em especial dos Municípios, à prestação de serviços públicos de saúde normatizados pelo Ministério da Saúde. O incentivo dos Municípios à capacitação seria instrumentalizado pelas transferências financeiras, na medida em que estas ocorram em contrapartida ao empenho dos Municípios em se habilitarem aos critérios normatizados para reconhecimento de suas capacidades de auto-gestão de suas respectivas estruturas de prestação de serviços de saúde pública.

Com esse enfoque, as NOB's passaram a definir não só as condições, como também os programas a serem implantados nos Municípios, baseadas em um consenso 
aceito sobre quais metas devam ser alcançadas por cada um dos Estados, além de considerarem as condições mínimas de operação do sistema.

Deste modo, e como já observamos anteriormente, sob influência da incorporação da estrutura de gestão do INAMPS, as primeiras NOB's, emitidas em 1991 e 1992, estabelecem os critérios para a transformação dos serviços de natureza pública, tanto estaduais quanto municipais, em prestadores "remunerados" conforme a produção, tal qual uma instituição privada ou filantrópica. Para viabilizar a implantação desses critérios, esta NOB institui um canal direto de comunicação entre o Ministério da Saúde e as Secretarias de Saúde municipais denominado "convênio(s) de municipalização", pelo qual estimula-se a implantação dos Fundos Municipais e Conselhos de Saúde.

A seguir o Ministério da Saúde edita em 1993 a Norma Operacional Básica, conhecida por NOB 01/93, a qual aprofunda o processo de descentralização para os Municípios ao regulamentar a gestão dos serviços de saúde no âmbito do SUS, estabelecendo os mecanismos de financiamento e as diretrizes de investimentos. Institui três diferentes estágios de gestão, os quais balizam o relacionamento entre a União e os demais entes federados - a incipiente, a parcial e a semiplena. Esta norma atribuía ao Município a condição de gestão semiplena, desde que este assumisse a total responsabilidade pelas ações em saúde, estabelecendo em contrapartida que, em assim fazendo, esse Município adquiriria o direito de receber transferências de recursos financeiros para o custeio de suas ações e serviços baseados no histórico de seus gastos, fundo a fundo, embora limitadas pelo teto ambulatorial e hospitalar estabelecido.

A NOB 01/93 elenca, entre os pressupostos do SUS, a descentralização a fim de que ocorra a completa reformulação do então predominante modelo centrado na assistência médico-hospitalar individual e, sem garantia de qualidade. Com isso, pretendia-se que o modelo de descentralização se deslocasse para a assistência universalizada, equânime e, regionalmente hierarquizada. Também pretendia a incorporação da responsabilidade sanitária em cada esfera de governo, em todos os pontos do sistema.

Porém, a NOB 01/93 também já traz uma postura pró-regionalização, na medida em que a burocracia do SUS sinaliza que os Municípios devam se articular e 
mobilizar em função de características geográficas, do fluxo de demanda, do perfil epidemiológico, da oferta de serviços e, acima de tudo, em razão da vontade política expressa pelas diversas elites municipais de se “(...) consorciar ou estabelecer qualquer outra relação de caráter cooperativo” .

Note-se que, ao mesmo tempo em que a NOB 01/93 define os princípios graduais e negociados da descentralização na saúde, também procura evitar solução de continuidade na atenção à saúde da população por meio da aceitação de um período de transição para aplicação de medidas compatíveis com a própria vontade das elites políticas municipais e respectivas capacidades de absorção de responsabilidades gerenciais e políticas.

Isso é perfeitamente compreensível dado o grande número de Municípios e a diversidade de realidades municipais. Afinal, impondo uma descentralização heterogênea e gradual, a tendência esperada era a solução de vários tipos de problema, não apenas os de natureza institucional, mas, principalmente, aqueles decorrentes da heterogeneidade regional e da desigualdade econômico-social que caracteriza o país.

A NOB 01/93 também cria duas estruturas decisórias atreladas ao SUS: as Comissões Intergestoras Bipartite (Estados e Municípios) e a Tripartite (União, Estados e Municípios). Ambas se configuram em arenas de negociação voltada à tomada de decisão política na área de saúde; ou seja, é onde "o diálogo, a negociação e a pactuação entre os atores vão constituir a base da legitimação das decisões"

(NOB 01/93).

Há que se observar que tais comissões abrem espaço para que as transferências de recursos financeiros sejam associadas ao poder de negociação política em contrapartida a eventuais vínculos a dispositivos legais. É nessas comissões que determinado Município submete o seu ingresso ao SUS, alinhando sua gestão a uma das classificações acima, e sempre dependente de negociação e aprovação da programação de recursos (Rinaldi e outros, 1996).

Acrescente-se que, com as NOB's, surgem regras de adesão implicitamente conveniais, e portanto, gerando incertezas quanto a possíveis intermediações no interior do SUS, dado que os termos à negociação e a pactuação não estão explicitamente determinados, quer seja na NOB 01/93 quanto na que lhe segue, a NOB-96. Com esse 
desenho da situação, se transparece a possibilidade de que Estados e Municípios com maior poder político e, historicamente mais desenvolvidos, tenham melhores condições de negociar junto à Direção Nacional do SUS.

Sustenta tal hipótese, a constatação de que as "regiões com maior degradação sócio-econômica e sanitária são as que possuem menor população coberta pela Gestão de Semi Plena-GSP, (...), tal que o percentual de Municípios em GSP é maior em regiões e estados com maior poder político no cenário nacional" (Misoczky e Ferreira, 1997).

A NOB-96 surge reduzindo as formas de gestão a duas: a plena da atenção básica e a plena do sistema municipal. Define-se a gestão plena de atenção básica como de responsabilidade pela elaboração da programação municipal dos serviços básicos, inclusive domiciliares e comunitários, e de uma proposta de referência ambulatorial especializada e hospitalar para seus munícipes a ser incorporada à programação estadual através de negociação na CIB.

Também define a gestão plena do sistema municipal pela atribuição de algumas responsabilidades, destacando-se entre elas, a da elaboração de toda a programação municipal, contendo inclusive, a referência ambulatorial especializada e hospitalar, mantendo sua incorporação junto à programação estadual sob negociação na respectiva CIB e, além disso, impondo algumas condições para que aqueles já enquadrados na condição semiplena da NOB 01/93 possam ser credenciados a esta nova classificação.

Dessa forma, novamente o Ministério da Saúde ratifica a descentralização em tipos, distinguindo formalmente os tipos de relações a se estabelecer entre entes federativos, o que não é previsto no texto constitucional. Além disto, para enquadrar-se em uma destas formas de gestão, e, portanto, para adquirir o direito a uma transferência de recursos financeiros de forma "regular e automática" com base, entre outros, no critério populacional, o Município continua obrigado a atender à imposição de uma série de requisitos e a assumir as responsabilidades.

Novamente a NOB, em sua versão 96, veio com a finalidade de promover e consolidar junto a Municípios e Estados, o pleno exercício da função de gestor da atenção à saúde, normatizando posturas constitucionais presentes nos incisos V e VII 
do art. 30 e no $\S 1^{\circ}$ do art. 32. Portanto, atribuindo "de fato" aos Municípios a responsabilidade pelo atendimento das necessidades imediatas de serviços de saúde da população; e, reordenando o modelo de atenção básica e redefinindo entre outros, os papéis de cada esfera de governo, em especial, no tocante à direção única. Assim sendo, a NOB-96 conceitua atenção básica como um conjunto de ações, de caráter individual ou coletivo, situadas no primeiro nível de atenção dos sistemas de saúde, voltadas para a promoção da saúde, prevenção, tratamento e reabilitação, nos quais se prioriza o caráter preventivo.

Ela também prevê que a totalidade das ações e serviços deva ser desenvolvida em um conjunto de estabelecimentos, organizados em estrutura regionalizada e hierarquizada, uma para cada Município (SUS-Municipal). Ela também permite que os estabelecimentos desse sistema não necessitem ser de propriedade das prefeituras, e nem precisam ter sede no território do Município; mas, sejam eles estatais ou privados, deverão ser geridos pelo Município de modo a garantir à população o acesso aos serviços, disponibilizando ações e meios para o atendimento integral. Ou seja, respeitadas as atribuições do Conselho de Saúde, a gestão dos estabelecimentos prestadores sempre será de competência do poder público sede do estabelecimento, independentemente de este ser privado ou estatal.

O papel atribuído aos Estados é a responsabilidade pela harmonização e uniformização entre os sistemas municipais. E o seu desempenho deve se dar por meio dos fóruns de negociação integrados por gestores municipais e estaduais - a Comissão Intergestores Bipartite (CIB), onde atuaria como mediador. Como já mencionado, os sistemas municipais de saúde apresentam níveis diferentes de complexidade entre si, sendo comum que estabelecimentos ou órgãos de saúde de um Município atendam a usuários encaminhados por outro.

Nesse caso, a NOB-96, no ideal de assegurar a universalidade do acesso, formaliza a possibilidade de um indivíduo recorrer ao estabelecimento prestador de serviços de saúde de outro Município, permitindo que acordos surjam de negociações efetuadas entre os gestores municipais envolvidos, sob a mediação do Estado, quando necessário; mas, sempre submetidos aos respectivos Conselhos de Saúde municipais. 
Essa mesma NOB-96, especificamente para a situação acima desenhada, confirma que a gestão do estabelecimento que prestar serviço a outros munícipes será atribuída ao Município sede, cabendo ao gestor do Município demandante o direito de solicitar auditoria, se necessário, ao gestor estadual.

Quanto ao ressarcimento das diversas ações de saúde ofertadas a indivíduos oriundos de outro Município, a NOB-96 regra-o da seguinte forma: das transferências a título de recursos destinados ao pagamento das diversas ações de atenção à saúde, serão alocados previamente pelo Município demandante ao Município sede do prestador, o qual incorpora os recursos, creditados diretamente em seu fundo de saúde, ao seu teto financeiro (que no âmbito municipal é definido consoante a programação integrada de saúde no Município, submetida pela Secretaria Municipal de Saúde à respectiva Secretaria Estadual, após aprovação pelo Conselho Municipal de Saúde), já devidamente considerados em seu Orçamento através de programação pactuada entre os gestores municipais. Quando o Município demandante ampliar sua própria capacidade resolutiva, poderá requerer ao gestor estadual que a sua parte de recursos alocados no Município vizinho lhe seja realocada.

O interessante é que, embora a NOB-96 nada fale diretamente em estruturas de cooperação intermunicipais, esta norma institucionaliza o compartilhamento das estruturas prestadoras de serviço, maximizando seus desempenhos, e abrindo espaço a discussões sobre externalidades.

$\mathrm{Na}$ realidade, as mudanças institucionais ocorridas no SUS nesse período, além de incrementais, sinalizavam que o modelo inicial adotado de descentralização estava em transformação. Isso fica evidente com as alterações conceituais que podemos observar entre a NOB-SUS 01/93 e a sua sucessora, a NOB-SUS 01/96, que variaram da implementação de dispositivos normativos que só tratavam da assistência, para uma primeira abordagem da descentralização da assistência, vigilância sanitária, epidemiologia e controle de doenças, a partir da qual, segundo Brasil (2002b), ocorre um significativo aumento do volume de recursos transferidos na modalidade fundo a fundo e um crescimento vertiginoso de Municípios habilitados na condição de gestão plena. 
Mais recentemente, novas mudanças institucionais ocorreram com a edição da Norma Operacional de Assistência à Saúde 01, de 2001 (NOAS-SUS 01/01), reorientando o modelo de descentralização para a regionalização, ratificando o papel coordenador dos Estados e possibilitando a resolução dos conflitos de acesso suscitados pelo padrão "autonomista" dos Municípios. Segundo Brasil (2002b), essa mudança caracterizou a saída de “(...) um modelo centrado numa concepção polar ou dual de federalismo, onde os Municípios inseridos em modalidades mais avançadas de gestão (semiplena, pela NOB-SUS 01/93; e gestão plena, pela NOB-SUS 01/96) definiam autonomamente suas políticas de saúde, referindo-se diretamente às orientações federais, garantidas por fluxos financeiros transferidos, de modo direto, do Fundo Nacional para os fundos municipais de saúde” .

A preocupação com o resgate do papel coadjuvante de coordenação das ações do SUS aos Estados advém exatamente dessa concepção dual de federalismo do modelo estritamente descentralizador das NOB's, o qual atribuía aos Estados um papel meramente residual, quando muito de certificador da aplicação das normas estabelecidas aos Municípios pela União. Tanto é verdade, que a NOB-SUS 01/96, embora reconhecesse a importância deles como coordenadores regionais, não lhes instituiu quaisquer mecanismos e instrumentos necessários de monitoramento para o efetivo exercício da função de coordenação.

Além disso, a partir dos conflitos decorrente da descentralização "versus" a autonomia administrativa já abordados, seria admissível aceitarmos que o modelo de descentralização inicialmente adotado pelo SUS possa ter ampliado os conflitos de competência jurisdicional. E que, ao acirrar as questões de comportamento competitivo intermunicipal, também ampliou a tendência à fragmentação do sistema de saúde público como um todo.

Ou seja, o modelo estritamente descentralizador, federativamente bipolar com a União, pode ter comprometido vínculos de solidariedade e o compartilhamento de responsabilidades intermunicipais. Afinal, cada elite política municipal, empreendendo uma política pública de saúde autônoma, tende a evitar possíveis demandas advindas de consumidores-eleitores de Municípios vizinhos. 
Por outro lado, tal atitude se esgota na necessidade de se melhor aproveitar os recursos disponíveis, gerando conflitos e pressões de vários grupos por novas regras que possam regulamentar as interações intermunicipais, ainda que a proposta dessa nova mudança institucional pudesse demandar maiores custos de monitoramento e de coordenação, na medida em que as elites políticas as interpretassem como um retrocesso centralizador do sistema.

\section{2. a institucionalização do modelo de regionalização (NOAS-SUS)}

O que se evidencia até este ponto, é que o SUS buscou a integração de ações de saúde pública envolvendo os três entes federativos; embora visando a municipalização desses serviços, transferindo um conjunto de responsabilidades e recursos antes concentrado no nível federal. A partir da implementação do Piso de Atenção Básica, ampliou-se o acesso à atenção básica, culminando no ano de 2000, com a habilitação, segundo o Ministério da Saúde, de cerca de $99 \%$ do total dos Municípios às condições de gestão previstas na NOB-SUS 01/96.

Nesse período, os Estados organizaram estruturas de serviços por meio do desenvolvimento do processo de programação integrada e implantaram centrais de regulação, de controle e, de avaliação. Algumas Secretarias Estaduais de Saúde SES's procuraram organizar estruturas de cooperação formatadas em consórcios intermunicipais, até então apenas previstos nas NOB's editadas, formulando e, em alguns casos, até financiando, planos de regionalização.

Evidentemente, é possível inferir-se que a gestão descentralizada com a participação das três esferas de governo, autônomas e sem vinculação hierárquica, tenha problemas de consenso entre os órgãos gestores envolvidos no SUS: o Ministério da Saúde - MS, o Conselho de Secretários Estaduais de Saúde - CONASS e o Conselho Nacional de Secretários Municipais de Saúde - CONASEMS.

Até porque, Estados e Municípios são heterogêneos e, a maioria dos Municípios são pequenos para gerirem um sistema funcional completo, assim como 
existem outros que são pólos de atração regional, com óbvios problemas de externalidades, os quais, algumas vezes, apresentam-se extensões interestaduais.

E talvez, por isso mesmo, que o SUS também busque, ao lado do objetivo de superação das restrições de acesso, garantindo-o universal, fazer com que o sistema de saúde pública seja integrado, o que implica que a sua burocracia deva também se preocupar com os efeitos da competição entre os Municípios. E, de certa forma, essa preocupação transparece nas entrelinhas na edição da NOAS-SUS 01/01, quando a burocracia do SUS se mostra preocupada com a "atomização do SUS em sistemas locais ineficientes" ; ao mesmo tempo em que se busca a descentralização e o acesso universal no setor, questões vinculadas ao enfoque de externalidades.

Enquanto as NOB`s procuravam a integração do sistema por via indireta, com a uniformização dos padrões de oferta de ações de saúde pública em cada Município, com a NOAS-SUS 01/01 passou-se a buscar a integração com ênfase na regionalização e no aumento da eqüidade, por meio da organização de sistemas de saúde funcionais com todos os níveis de atenção, não necessariamente confinados aos territórios municipais e, desta forma, abrindo-se espaço à coordenação dos Estados.

É interessante na NOAS-SUS 01/01 a ampliação do acesso aos serviços de atenção básica com foco nos consumidores-eleitores de uma determinada região, e não mais necessariamente de um dado Município. Para isso, sem perder a característica descentralizadora pretendida constitucionalmente, organiza-se a prestação dos serviços, regionalizado o sistema por meio da hierarquização da capacidade dos diversos Municípios em prestar serviços de saúde.

Uma das consequiências é a necessidade de alguma forma de planejamento integrado com noções de territorialidade de forma a garantir o acesso dos consumidores-eleitores e otimizar os recursos disponíveis na região. Assim sendo, o NOAS-SUS 01/01 conferiu a cada Secretaria de Estado da Saúde - SES a responsabilidade pela elaboração de um Plano Diretor de Regionalização - PDR para o ordenamento do processo de regionalização, considerando as necessidades de saúde dos consumidores-eleitores e a garantia de acesso a todos os níveis de atenção previstos no Plano Estadual de Saúde. Esse Plano Diretor deveria ser aprovado pela Comissão 
Intergestores Bipartite - CIB e pelo Conselho Estadual de Saúde - CES, e, então, encaminhamento ao Ministério da Saúde.

O Plano Diretor de Regionalização deve definir a organização da assistência e as diversas bases territoriais, considerando as características demográficas, sócioeconômicas, geográficas, sanitárias, epidemiológicas, oferta de serviços, e, principalmente, as relações entre Municípios. A NOAS-SUS 01/01 define como a menor base territorial a que envolva um ou mais módulos assistenciais, ao primeiro ${ }^{202}$ nível de referência ${ }^{203}$ intermunicipal.

Além disso, a NOAS-SUS 01/01 especifica que os serviços mínimos de um módulo podem ser ofertados por mais de um Município, desde que entre eles pelo menos um assuma a condição de Município-Sede e esteja habilitado em Gestão Plena do Sistema Municipal/GPSM com capacidade de ofertar a totalidade dos serviços de média complexidade, com suficiência, para sua população e à dos demais próximos. Se o módulo for composto pela jurisdição de apenas um Município, este também deverá estar habilitado à Gestão Plena do Sistema Municipal e, não poderá estar no papel de referência a outros Municípios.

Portanto, no Plano Diretor de Regionalização, deverá, além de organizar a assistência à saúde, conter a divisão territorial em regiões/microrregiões de saúde e módulos assistenciais, identificando os Muncípios-Sede, os Municípios-Pólo ${ }^{204}$ e, os demais Municípios. Também deve identificar as prioridades de intervenção em cada região/microregião, discriminando o Plano Diretor de Investimentos e a inserção e o

202 O anexo 3 da NOAS-SUS 01/01 define um conjunto mínimo de procedimentos de média complexidade como primeiro nível de referência intermunicipal, aquele com acesso garantido a toda a população no âmbito microrregional, ofertados em um ou mais módulos assistenciais. Esse conjunto compreende as atividades ambulatoriais, de apoio diagnóstico e terapêutico e de internação hospitalar.

203 Define-se esse nível de referencia como um conjunto mínimo de procedimentos de média complexidade ao nível intermunicipal, com acesso garantido a um conjunto mínimo de serviços ofertados compreendendo as atividades ambulatoriais, de apoio diagnóstico e terapêutico e de internação hospitalar.

204 A NOAS-SUS 01/01 define o Município-pólo como aquele que, de acordo com a definição da estratégia de regionalização de cada Estado, apresente papel de referência para outros Municípios, em qualquer nível de atenção. 
papel dos Municípios envolvidos, identificando sua área de abrangência e os fluxos ${ }^{205}$ de referência, inclusive a outros Estados, de serviços não disponíveis no próprio território estadual.

A NOAS-SUS 01/01 também institui a Gestão Plena da Atenção Básica Ampliada - GPAB-A, definindo como atuação mínima para habilitação o controle e a ação sobre algumas enfermidades ${ }^{206}$; cujos procedimentos serão financiados pelo PABAmpliado $^{207}$ com valores definidos por Portaria Conjunta da Secretaria Executiva/SE e da Secretaria de Políticas de Saúde/SPS, sendo que os Municípios que já recebem o $\mathrm{PAB}$ fixo em valor superior ao PAB-Ampliado não terão acréscimo no valor "per capita".

\subsection{1. das ações de média complexidade e/ou custo}

As transferências financeiras em razão dos procedimentos de média ${ }^{208}$ complexidade, tais como o primeiro nível de referência intermunicipal, segundo a

\footnotetext{
${ }^{205}$ Ou seja, deve tratar dos mecanismos de relacionamento intermunicipal considerados na organização de fluxos de referência e contra referência, além de tratar da implantação de estratégias de regulação visando à garantia do acesso os serviços; propondo a estruturação de estruturas de referência especializada.

206 A tuberculose, a eliminação da hanseníase, o controle da hipertensão arterial, o controle da diabetes mellitus, a saúde da criança, a saúde da mulher e a saúde bucal. Essas ações devem ser assumidas pelos Municípios de acordo com o seu perfil epidemiológico, como um componente essencial e mínimo para o cumprimento das metas do Pacto da Atenção Básica, instituído pela Portaria GM/MS no 3.925/98; incluindo-se os procedimentos atualmente já cobertos pelo Piso de Atenção Básica - PAB.
}

${ }^{207}$ O PAB-Ampliado destina-se aos Municípios habilitados às condições de gestão da NOB 01/96, após a avaliação da correspondente Secretaria de Estado da Saúde, a aprovação da Comissão Intergestores Bipartite - CIB, e a homologação da Comissão Intergestores Tripartite - CIT. Ficou para a Secretaria de Políticas de Saúde/SPS do Ministério da Saúde a competência de regulamentar esse processo, submetendo-se à CIT para deliberação.

${ }^{208}$ A Atenção de Média Complexidade - MC - compreende um conjunto de ações e serviços ambulatoriais e hospitalares, que demanda profissionais especializados e a utilização de recursos tecnológicos de apoio diagnóstico e terapêutico, e cuja oferta não se encontra em todos os Municípios. Portanto, excetuando-se o conjunto mínimo de ações de média complexidade, que devem ser garantidos no âmbito microrregional, as demais ações assistenciais de média complexidade, tanto ambulatoriais como hospitalares, podem ser garantidas no âmbito microrregional, regional ou mesmo estadual, de acordo com o tipo de serviço, a disponibilidade tecnológica, e, a definição no Plano Diretor de Regionalização do Estado, por meio do qual, o gestor estadual organiza regionalmente as ações de média complexidade, em apoio à Secretaria de Assistência à Saúde SAS/MS. 
NOAS-SUS 01/01, adotará a seguinte lógica: o financiamento das ações ambulatoriais será com base em valor per capita nacional definido em portaria conjunta da Secretaria Executiva/SE e Secretaria de Assistência à Saúde/SAS, submetida à Comissão Intergestores Tripartite. Quanto ao financiamento das internações hospitalares será de acordo com o processo de Programação Pactuada e Integrada, conduzido pelo gestor estadual, respeitado o Teto Financeiro da Assistência/TFA de cada Unidade da Federação.

Ao longo do processo de qualificação das microrregiões, o Ministério da Saúde adicionará recursos ao Teto Financeiro dos Estados para cobrir a diferença entre os gastos atuais desses procedimentos e o montante correspondente ao "per capita" nacional multiplicado pela população e, nas microrregiões não qualificadas, o financiamento dos procedimentos de média complexidade será feito de acordo com a lógica de pagamento por produção.

Para que uma dada microregião receba a transferência financeira, deverá ter sua qualificação à assistência à saúde aprovada pela CIT. Nos Estados cuja regionalização não envolva regiões de saúde, a unidade territorial de qualificação ${ }^{209}$ na assistência à saúde será a menor base territorial acima do módulo assistencial, desde que atenda à consistência do Plano Diretor de Regionalização e às mesmas condições que seriam exigidas na qualificação das microrregiões. A Secretaria de Assistência à Saúde - SAS / MS, além de regulamentar o processo de qualificação das microrregiões na assistência a saúde, também analisa essas propostas, submetendo-as a CIT.

A qualificação depende do desenho que o Plano Diretor de Regionalização faz de todas as microrregiões, além da apresentação, para cada microregião a ser qualificada, dos Municípios que a compõem. Ou seja, a qualificação depende da definição dos módulos assistenciais existentes, e deve vincular cada Município da microregião a um único Município-Sede, de forma que cada um deles integre somente

\footnotetext{
209 A NOAS-SUS 01/01 define a "Unidade Territorial de Qualificação" na assistência à saúde como a base territorial mínima a ser submetida à aprovação do Ministério da Saúde e Comissão Intergestores Tripartite para qualificação na assistência à saúde, que deve ser a menor base territorial de planejamento regionalizado de cada Unidade da Federação acima do módulo assistencial, seja uma microregião de saúde ou uma região de saúde (nas UF em que o modelo de regionalização adotado não admitir microrregiões de saúde).
} 
um módulo assistencial, e a totalidade dos módulos assistenciais cubra a população do Estado.

Além de se exigir que o Município-Sede do módulo assistencial se enquadre na Gestão Plena do Sistema Municipal, todos os demais da microregião devem se enquadrar, pelo menos, na condição de Gestão Plena da Atenção Básica Ampliada.

Cada microrregião, assim definida pelo Plano Diretor de Regionalização, deve ser prevista na Programação Pactuada e Integrada - PPI ${ }^{210}$, sob coordenação do gestor estadual, pela qual são definidos os limites financeiros para todos os Municípios, os serviços prestados autonomamente aos respectivos grupos jurisdicionais de consumidores-eleitores e, os serviços de referência intermunicipal. Também deve ser firmado o Termo ${ }^{211}$ de Compromisso para Garantia de Acesso entre cada Municípiosede e o Estado para o atendimento dos consumidores-eleitores de outros Municípios a

${ }^{210}$ O processo de Programação Pactuada e Integrada - PPI, coordenado pelo gestor estadual representa a garantia de acesso da população aos serviços de média complexidade não disponíveis em seu Município de residência. O PPI orienta a alocação de recursos e define os limites financeiros para todos os Municípios de um Estado, independente da condição de gestão. Também programa as ações ambulatoriais de média complexidade, tal que, a alocação de recursos referentes a cada população de um dado Município terá como limite financeiro o valor per capita estadual definido, e multiplicado pela respectiva população. Define-se limite financeiro da assistência por Município como o limite máximo de recursos federais gasto com o conjunto de serviços existentes em cada território municipal, sendo composto por duas parcelas: recursos ao atendimento da população própria e recursos destinados ao atendimento da população referenciada de acordo com as negociações expressas na PPI. Esses limites por Município devem ser definidos em cada Estado a partir de critérios e parâmetros de programação ambulatorial e hospitalar, respeitado o limite financeiro estadual, bem como da definição de referências intermunicipais na PPI.

211 O anexo 4 da NOAS-SUS 01/2001 traz uma minuta do Termo de Compromisso para Garantia de Acesso, que se rege pela Lei $n^{\circ} 8.666$, de 21 de junho de 1993 e suas alterações. Trata-se de um compromisso a ser celebrado entre a Secretaria de Estado da Saúde e a Secretaria Municipal da Saúde do Município-sede, visando o atendimento por esta última, desde que habilitada à condição de Gestão Plena do Sistema Municipal, às referências intermunicipais ambulatoriais, hospitalares e de apoio diagnóstico e terapêutico, definidas na Programação Pactuada Integrada - PPI, garantindo a atenção às necessidades de saúde dos consumidores-eleitores, independente de seu Município de residência, de acordo com os princípios do Sistema Único de Saúde de universalidade do acesso e integridade da atenção. A PPI explicitará os fluxos de referência acordados entre as elites políticas municipais; os relatórios consolidados das ações e serviços de referência a serem prestados pelo Município-sede; o montante de recursos financeiros correspondentes a essas referências; o limite financeiro do Município-sede (discriminando os recursos da população própria e os relativos às referências intermunicipais); os mecanismos de operacionalização e/ou acompanhamento dos acordos e os critérios de revisão dos compromissos estabelecidos. O Termo decorre de um processo prévio de realização da PPI coordenada pelo gestor estadual e aprovada pela CIB, na qual a SMS do Município-sede se compromete a atender, em serviços disponíveis em seu território, à população residente dos Municípios listados em anexo ao Termo. 
ele referenciados. Dessa forma, para cada Município deverá ser gerado um limite a partir da programação ao atendimento do próprio grupo populacional, deduzida da necessidade de encaminhamento para outros Municípios e acrescida da programação para atendimento de referências recebidas de outros Municípios.

Após a qualificação de uma microregião, o montante de recursos correspondente aos procedimentos de média complexidade destinados à cobertura dos próprios consumidores-eleitores, ou daqueles residentes nos Municípios a ele referenciados, são transferidos fundo a fundo ao Município-Sede de cada módulo assistencial, sendo que a parcela relativa à população residente nos demais Municípios da microregião estará condicionada ao cumprimento do Termo de Compromisso para a Garantia de Acesso.

A NOAS-SUS 01/01 também prevê que caso exista na microregião qualificada um Município habilitado em Gestão Plena da Atenção Básica que disponha em seu território alguns serviços especializados, em quantidade e qualidade adequada para o atendimento de seu próprio grupo de consumidores-eleitores, mas que não tenha o conjunto de serviços requeridos para ser habilitado em Gestão Plena do Sistema Municipal, poderá celebrar um acordo com o Município-Sede do módulo assistencial para, provisoriamente, atender seus residentes no referido serviço.

Agora, se as ações de média complexidade estiverem dispersas por vários Municípios, a NOAS-SUS 01/01 admite que um mesmo Município encaminhe referências para mais de um pólo de média complexidade, dependendo da disponibilidade de oferta, condições de acesso e fluxos estabelecidos na PPI. Cabe ao gestor estadual evitar a superposição de serviços, de tal modo que a mobilidade observada na região flua dos Municípios de menor complexidade, tais como os "latentes", para os de maior complexidade, a exemplo dos "privilegiados", computando no Município exportador de serviços, as parcelas físicas e financeiras correspondentes ao atendimento dos consumidores-eleitores dos Municípios de origem.

\subsection{2. das ações de alta complexidade e/ou custo}


Até aqui, envolvemos as ações de média complexidade. Quanto às políticas de saúde de alta complexidade/custo, estas são de responsabilidade do Ministério da Saúde, principalmente no que tange à definição de normas quanto aos procedimentos ofertados. No entanto, as garantias ${ }^{212}$ de acesso a esses serviços têm a responsabilidade solidária das Secretarias de Estado da Saúde.

Além disso, o gestor estadual detém a responsabilidade intransferível sobre as funções de definição de prioridades assistenciais e programação da alta complexidade, vinculada à política nacional, incluindo a definição da alocação de recursos orçamentários do Teto Financeiro da Assistência - TFA do Estado para cada área de alta complexidade, o que de certa forma explica a necessidade de se atribuir aos Estados a responsabilidade pela coordenação e definição de prioridades de investimentos para garantir o acesso da população, inclusive os de referência intermunicipais.

Segundo a NOAS-SUS 01/01, a burocracia estadual também é responsável pela delimitação da área de abrangência dos serviços de alta complexidade; pela definição de limites financeiros para a alta complexidade, com explicitação da parcela correspondente ao atendimento da população do Município onde está localizado o serviço e da parcela correspondente a referências de outros Municípios; pela condução dos remanejamentos necessários na programação da alta complexidade; pelos processos de vistoria para inclusão de novos serviços; pela implementação de mecanismos de regulação da assistência em alta complexidade (centrais de regulação, implementação de protocolos clínicos, entre outros), podendo ser delegável aos Municípios a operação desses mecanismos; pelo controle e a avaliação do sistema, quanto à sua resolubilidade

\footnotetext{
212 O anexo 5 da NOAS-SUS 01/01 traz uma minuta do Termo de Compromisso para Garantia de Acesso que entre si celebram Município-sede de um hospital de referencia para atendimento de alta complexidade por intermédio de sua Secretaria Municipal de Saúde e o Estado onde se localiza a jurisdição desse Município, por intermédio de sua Secretaria de Estado da Saúde. Visa formalizar a contratação dos serviços de saúde ofertados e respectiva forma de pagamento dessa unidade hospitalar, sob gerência do Estado, definindo o papel do hospital no sistema municipal e supramunicipal de acordo com a abrangência e o perfil dos serviços a serem oferecidos, em função das necessidades de saúde da população, determinando as metas físicas a serem cumpridas; volume de prestação de serviços; grau de envolvimento do hospital na estrutura estadual de referência; humanização do atendimento; melhoria da qualidade dos serviços prestados à população e outros fatores que tornem o hospital um efetivo instrumento na garantia de acesso ao Sistema Único de Saúde - SUS.
} 
e acessibilidade; e, pela otimização da oferta de serviços, em termos dos recursos disponíveis, garantindo economia de escala e qualidade.

Os Municípios que oferecem serviços de alta complexidade/custo em sua jurisdição, quando habilitados em Gestão Plena do Sistema Municipal, são responsáveis pela organização desses serviços em seu território. Já os Municípios habilitados em Gestão Plena da Atenção Básica - GPAB ou Gestão Plena da Atenção Básica Ampliada - GPAB-A, que tenham serviços de alta complexidade em seu território, a responsabilidade pela gestão poderá ser delegada a eles pelo gestor estadual.

O financiamento se dará de duas formas: parte será financiada com recursos do Teto Financeiro da Assistência dos Estados e, outra parte, com recursos do Fundo de Ações Estratégicas e Compensação - FAEC, gerenciado pelo Ministério da Saúde.

No geral, o Ministério da Saúde define os valores de recursos destinados a ações de alta complexidade a cada Estado, e estes, de acordo com a PPI e dentro do limite financeiro estadual, parcelarão os recursos aos Municípios, destacando a cada área de alta complexidade, uma parcela para a população do próprio Município e outra para as ações que se refiram à população de referência oriunda de outros Municípios.

Essa programação deve prever o fluxo de outros Estados, e consolidada pela SAS/MS; além de ser precedida de estudos da distribuição regional de serviços e da proposição pela Secretaria de Estado da Saúde/SES de um limite financeiro claro para seu custeio, com o Plano Diretor de Regionalização apontando as áreas de abrangência dos Municípios-Pólo desses serviços de referência de Alta Complexidade.

\subsection{3. do financiamento às ações de média e alta complexidade e/ou custo}

Independente das assistências serem de média ou alta complexidade, os Municípios habilitados à Gestão Plena do Sistema Municipal recebem diretamente em seu Fundo Municipal de Saúde os recursos federais correspondentes aos limites 
financeiros programados, que podem ser reprogramados pela revisão periódica da PPI, coordenada $^{213}$ pelo gestor estadual.

A parcela correspondente às referências intermunicipais é revista trimestralmente a partir de ajustes no Termo de Compromisso e, além disso, a SES poderá alterá-la em razão de ajuste no fluxo de atendimento das referências, tais como: abertura de novo serviço em Município que encaminhava seus consumidores-eleitores para outro; redirecionamento do fluxo de referência da população de um Municípiopólo para outro; e, problemas no atendimento da população referenciada ou descumprimento pelo Município em GPSM dos acordos estabelecidos no Termo de Compromisso para Garantia de Acesso.

Quanto ao atendimento dos consumidores-eleitores referenciados entre Estados a responsabilidade é do Ministério da Saúde, solidariamente com as Secretarias estaduais envolvidas; enquanto que a garantia ao acesso de serviço de saúde pública não disponível no Município de residência de um consumidor-eleitor é de responsabilidade do gestor estadual, de forma solidária com o Município de referência, observado o limite financeiro e, se habilitado em GPSM, deverá também observar o Termo de Compromisso para Garantia de Acesso.

\section{3. - as mudanças institucionais no modelo de regionalização (NOAS-SUS)}

Pode-se visualizar na Tabela III a seguir, um breve resumo das principais mudanças institucionais ocorridas no SUS. Essas mudanças incrementais apontam a transformação do modelo de descentralização, institucionalizado por meio de sucessivas NOB's, que migra para um enfoque de regionalização da prestação de

\footnotetext{
${ }^{213}$ Contendo a referência intermunicipal e pactos de negociação na CIB para alocação dos recursos; a coordenação do sistema de referências intermunicipais, organizando o acesso da população, bem como a normalização e operação de câmara de compensação para internações, procedimentos especializados e de alto custo e ou alta complexidade, viabilizando com os Municípios-Pólo os Termos de Compromisso para a Garantia de Acesso; a gestão dos sistemas municipais nos Municípios não habilitados; a normalização complementar de mecanismos e instrumentos de administração da oferta e controle da prestação de serviços ambulatoriais, hospitalares, de alto custo; a cooperação técnica e financeira com o conjunto de Municípios, para a descentralização e a organização da estrutura regionalizada e hierarquizada de serviços.
} 
serviços de saúde pública, principalmente aqueles de média e alta complexidade. Tem sido nosso objetivo demonstrar que o SUS, com essas mudanças, é uma organização que assume o papel de indutora de estruturas de cooperação intermunicipal no formato convênio, institucionalizando-as por meio das NOAS's.

Ocorre que, o modelo de descentralização regionalizada instituído pela NOAS-SUS é ajustado por meio da Portaria n 373/GM, de 27 de fevereiro de 2002, oportunidade em que o Ministro da Saúde, “(...) no uso de suas atribuições, e considerando os princípios do Sistema Único de Saúde de universalidade do acesso, de integralidade da atenção e o disposto no Artigo 198 da Constituição Federal de 1998, que estabelece que as ações e serviços públicos de saúde integram uma rede (estrutura) regionalizada e hierarquizada e constituem um sistema único, aprova (...)” uma nova Norma Operacional da Assistência à Saúde, a NOAS-SUS 01/02.

A NOAS-SUS 01/02, além de ampliar as responsabilidades dos Municípios na Atenção Básica, deixa claro que o processo de regionalização existe como uma estratégia de hierarquização dos serviços de saúde e de busca de maior eqüidade. Para isso, a NOAS-SUS 01/02 cria mecanismos para o fortalecimento da capacidade de coordenação, principalmente, a da burocracia estadual do SUS e, atualiza os critérios de habilitação de Estados e Municípios.

A motivação para esta mudança institucional ocorreu a partir da publicação da NOAS-SUS 01/01, em 26 de janeiro de 2001, quando então, o Ministério da Saúde, as Secretarias Estaduais de Saúde, através do CONASS, e as Secretarias Municipais de Saúde, através do CONASEMS, desencadearam diversas atividades de planejamento e de adequação de seus modelos assistenciais e de gestão.

Também foram identificados na implantação da NOAS-SUS 01/01, em alguns Estados, alguns entraves decorrentes das dificuldades para estabelecer o comando único sobre os prestadores de serviços ao SUS e assegurar a totalidade da gestão municipal nas sedes dos módulos assistenciais. Além disso, constatou-se a fragilidade dos mecanismos à disposição das burocracias estaduais e, necessários para lidarem com as referências intermunicipais. 
Tabela III - Principais mudanças institucionais no SUS - período 1991 a 2001

\begin{tabular}{|c|c|c|c|c|}
\hline norma & $\begin{array}{c}\text { Instrumento } \\
\text { normativo }\end{array}$ & Cooperação Intermunicipal & $\begin{array}{c}\text { Modelo de } \\
\text { Financiamento } \\
\end{array}$ & $\begin{array}{c}\text { Tempo de } \\
\text { vigência }\end{array}$ \\
\hline \multirow[b]{2}{*}{$\begin{array}{l}\text { NOB } \\
01 / 91\end{array}$} & $\begin{array}{c}\text { Resolução no } 258 \\
\text { de 01/91 (Pres. } \\
\text { do INAMPS) }\end{array}$ & Nihil & \multirow{2}{*}{$\begin{array}{l}\text { - } \begin{array}{l}\text { Repasse condicionado à } \\
\text { produção de serviços }\end{array} \\
\text { - Iguala pagamento do } \\
\begin{array}{l}\text { prestador público ao } \\
\text { privado }\end{array}\end{array}$} & \multirow[b]{2}{*}{7 meses } \\
\hline & $\begin{array}{c}\text { Resolução n²73 } \\
\text { de } 07 / 91 \text { (Sec. } \\
\text { Nac, de Ass. à } \\
\text { Saúde e o Pres. } \\
\text { do INAMPS) }\end{array}$ & Nihil. & & \\
\hline $\begin{array}{l}\text { NOB } \\
01 / 92\end{array}$ & $\begin{array}{l}\text { Portaria n } 234 \\
\text { de } 07 / 02 / 92 \\
\text { (Sec. Nac, de } \\
\text { Ass. à Saúde e o } \\
\text { Pres. do } \\
\text { INAMPS) } \\
\end{array}$ & Nihil. & $\begin{array}{ll}\text { - } & \begin{array}{l}\text { Repasse condicionado à } \\
\text { produção de serviços }\end{array} \\
\text { - } & \begin{array}{l}\text { Iguala pagamento do } \\
\text { prestador público ao } \\
\text { privado }\end{array}\end{array}$ & $\begin{array}{c}1 \text { ano e } 4 \\
\text { meses }\end{array}$ \\
\hline NOB/93 & $\begin{array}{c}\text { Portaria } \\
\text { MS/ GM n }{ }^{\circ 545} \\
\text { de } 20 / 05 / 93\end{array}$ & $\begin{array}{llr}\text { Sinaliza a } & \text { possibilidade } & \text { de } \\
\text { articulação em função } & \text { de } \\
\text { características } & \text { geográficas, fluxo } \\
\text { de demanda e da vontade política } \\
\text { das elites municipais. }\end{array}$ & $\begin{array}{l}\text { - } \text { Refere o repasse de } \\
\text { recursos a municípios } \\
\text { habilitados, mas não } \\
\text { define os mecanismos e } \\
\text { não rompe totalmente } \\
\text { com a lógica do pós- } \\
\text { pagamento }\end{array}$ & $\begin{array}{c}3 \text { anos e } 6 \\
\text { meses }\end{array}$ \\
\hline $\begin{array}{l}\text { NOB } \\
01 / 96\end{array}$ & $\begin{array}{c}\text { Portaria } \\
\text { MS/ GM n } \text { n }^{\circ} 2203 \\
\text { de } 06 / 11 / 96\end{array}$ & $\begin{array}{c}\text { Atribui "de fato" a } \\
\text { responsabilidade pela prestação de } \\
\text { serviços de atenção básica às elites } \\
\text { políticas, permitindo que se } \\
\text { desenvolvam em caráter coletivo. } \\
\text { Permite que os prestadores não } \\
\text { sejam do próprio Município, } \\
\text { embora se deva administrar meios } \\
\text { que garantam o acesso integral à } \\
\text { sua população. }\end{array}$ & 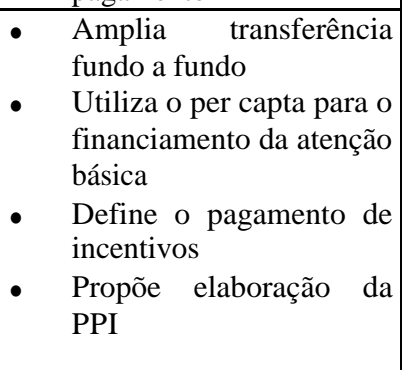 & $\begin{array}{c}\text { Implantada } \\
\text { em 01/1998, } \\
\text { e vigorou } \\
\text { até } 01 / 2001\end{array}$ \\
\hline $\begin{array}{c}\text { NOAS } \\
01 / 01\end{array}$ & $\begin{array}{c}\text { Portaria MS/GM } \\
n^{\circ} 95 \mathrm{de} \\
26 / 01 / 01\end{array}$ & $\begin{array}{l}\text { Institui a regionalização da } \\
\text { prestação de serviços de saúde } \\
\text { pública, formatada por uma } \\
\text { arquitetura de Termos de } \\
\text { Compromisso de Acesso sob } \\
\text { coordenação da burocracia } \\
\text { estadual e, definida por meio de } \\
\text { um Plano Diretor de } \\
\text { Regionalização, sob } \\
\text { responsabilidade dos respectivos } \\
\text { Estados. }\end{array}$ & 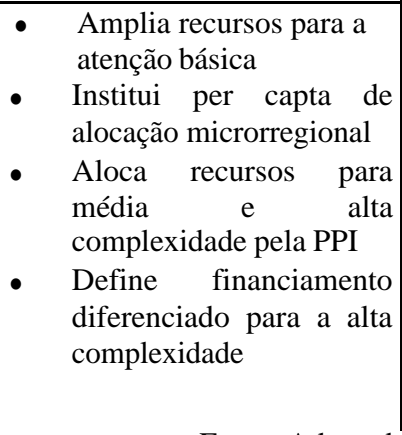 & $\begin{array}{c}1 \text { ano e } 1 \\
\text { mês }\end{array}$ \\
\hline
\end{tabular}

Esses problemas foram identificados e formalizados em reunião da Comissão Intergestores Tripartite (CIT), realizada em 22 de novembro de 2001, na qual se firmou acordo pró-comando único sobre os prestadores de serviços de média e alta complexidade e o fortalecimento da gestão dos Estados sobre as referências 
intermunicipais. Nessa mesma ocasião, deliberou-se pela constituição dos ajustes necessários à NOAS, dentre os quais, destaca-se a intenção de se assegurar a manutenção das diretrizes organizativas definidas pela NOAS-SUS 01/01, ratificandose a regionalização como uma estratégia de hierarquização dos serviços de saúde e de busca de maior eqüidade.

Trata-se de um processo que deve contemplar uma lógica de planejamento integrado, considerando “(...) as questões de territorialidade, de identificação das prioridades e de conformação dos vários sistemas de saúde envolvidos e, não necessariamente restritos à abrangência municipal, mas respeitando seus limites como unidade indivisível, de forma a garantir o acesso dos cidadãos a todas as ações $e$ serviços necessários para a resolução de seus problemas de saúde, otimizando os recursos disponíveis na região” (NOAS-SUS 01/02).

Para que isso possa ser efetivado, o NOAS 01/02 mantém o instituto do Plano Diretor de Regionalização - PDR como instrumento de ordenamento do processo de regionalização. Além disso, também confirma o Plano Diretor de Investimentos já previsto pela anterior.

Especificamente quanto ao PDR, a NOAS-SUS 01/02 também justifica a sua necessidade para a conformação de sistemas funcionais e resolutivos de assistência à saúde, por meio da organização dos territórios estaduais em regiões/microrregiões e módulos assistenciais; para a conformação de estruturas hierarquizadas de serviços; e, para o estabelecimento de mecanismos e fluxos de referência econtra-referência intermunicipais, objetivando garantir a integralidade da assistência e o acesso da população aos serviços e ações de saúde de acordo com suas necessidades.

Para os Estados e o Distrito Federal se qualificarem à NOAS-SUS 01/02, deverão submeter à CIT os resultados esperados, bem como os meios de monitoramento correspondentes, que devem ser definidos considerando-se, no mínimo: a descrição da organização do território estadual em regiões/microrregiões de saúde ${ }^{214}$ e

\footnotetext{
${ }^{214}$ A NOAS-SUS 01/02 define região de Saúde como sendo a base territorial de planejamento da atenção à saúde, não necessariamente coincidente com a divisão administrativa do Estado, a ser definida pela Secretaria Estadual de Saúde, de acordo com as especificidades e estratégias de regionalização da saúde em cada Estado, considerando as características demográficas, socioeconômicas, geográficas, sanitárias, epidemiológicas, oferta de serviços, relações entre municípios, entre outras. Dependendo do modelo de
} 
módulos assistenciais $^{215}$, com a identificação dos Municípios-sede ${ }^{216}$ e Municípiospólo $^{217}$ e dos demais Municípios envolvidos; a identificação das prioridades de intervenção ${ }^{218}$ em cada região/microrregião.

A NOAS-SUS 01/02 trata a Gestão Plena da Atenção Básica Ampliada ${ }^{219}$ (GPAB-A) como uma das condições de gestão dos sistemas municipais de saúde, definindo as áreas de atuação estratégicas mínimas para que um dado Município adquira esta condição. Evidentemente, a burocracia do SUS espera que as ações previstas no Anexo 1 da NOAS-SUS 01/02, que estabelecem as condições para que um dado Município adquira a condição GPAB-A, sejam assumidas por todos como um componente essencial e mínimo para o cumprimento das metas do Pacto da Atenção

regionalização adotado, um Estado pode se dividir em macrorregiões, regiões e/ou microrregiões de saúde. Por sua vez, a menor base territorial de planejamento regionalizado, seja uma região ou uma microrregião de saúde, pode compreender um ou mais módulos assistenciais.

215 A NOAS-SUS 01/02 define módulo assistencial como o módulo territorial com resolubilidade correspondente ao primeiro nível de referência (definida no Item 8, capítulo I, da NOAS 01/02), constituído por um ou mais Municípios, com área de abrangência mínima a ser estabelecida para cada Estado, em regulamentação específica, e com as seguintes características: conjunto de Municípios, entre os quais há um Município-sede, habilitado em Gestão Plena do Sistema Municipal/GPSM ou em Gestão Plena da Atenção Básica Ampliada (GPAB-A), com capacidade de ofertar a totalidade dos serviços correspondentes ao primeiro nível de referência da NOAS-SUS 01/02, com suficiência, para sua população e para a população de outros Municípios próximos; ou um Município em Gestão Plena do Sistema Municipal ou em Gestão Plena da Atenção Básica Ampliada (GPAB-A), com capacidade de ofertar com suficiência a totalidade dos serviços correspondentes ao primeiro nível de referência para sua própria população, quando não necessitarem desempenhar o papel de referência para outros Municípios.

${ }^{216}$ A NOAS-SUS 01/02 define o Município-sede de um módulo assistencial (GPSM ou GPAB-A) como aquele que apresente a capacidade de ofertar a totalidade dos serviços de que trata o item 8, do capítulo I, da NOAS-SUS 01/02, correspondente ao primeiro nível de referência intermunicipal, com suficiência, para sua população e para a população de outros municípios a ele próximos.

217 A NOAS-SUS 01/02 define Município-pólo (GPSM ou GPAB-A) como aquele que, de acordo com a definição da estratégia de regionalização de cada Estado, apresente papel de referência para outros Municípios, em qualquer nível de atenção.

${ }^{218}$ A NOAS-SUS 01/02 identifica cada unidade territorial de qualificação na assistência à saúde como aquela que representa uma base territorial mínima a ser submetida à aprovação do Ministério da Saúde e Comissão Intergestores Tripartite para qualificação na assistência à saúde. Entende-se neste caso, que esta unidade deverá ser a menor base territorial de planejamento regionalizado com complexidade assistencial acima do módulo assistencial, que deve estar definido no PDR. Portanto, cada unidade territorial poderá ser uma microrregião ou uma região de saúde, de acordo com o desenho adotado pela respectiva Secretaria de Saúde do Estado.

219 Observe-se que os procedimentos deste tipo de gestão foram ampliados pelos relacionados no Anexo 2 da NOAS-SUS 01/02. 
Básica inicialmente instituído pela Portaria GM/MS n. ${ }^{\circ} 3.925$, de 13 de novembro de 1998.

Para o financiamento dos procedimentos da Atenção Básica Ampliada, foi instituído o PAB ampliado, e seu valor definido em Portaria do Ministério da Saúde, sendo que os Municípios que hoje já recebem o PAB fixo em valor superior ao PAB ampliado não sofrerão alteração no valor per capita do PAB fixo.

A NOAS 01/02 define um conjunto mínimo de procedimentos de média complexidade $^{220}$ como primeiro nível de referência intermunicipal, os quais compreendem as atividades ambulatoriais de apoio diagnóstico e terapêutico (M1) e de internação hospitalar, cujo acesso deverá ser garantido a todos os grupos jurisdicionais de consumidores-eleitores de uma dada região definida no PDR pela burocracia do Estado correspondente.

O financiamento da União a esse conjunto de serviços adotará a seguinte lógica: as atividades ambulatoriais de apoio diagnóstico e terapêutico (M1) serão financiadas com base na programação de um valor per capita nacional mínimo, definido em Portaria do Ministro da Saúde e, as internações hospitalares serão financiadas de acordo com o processo de Programação Pactuada e Integrada, conduzido pela burocracia estadual, respeitado o Limite Financeiro Global da Assistência de cada Estado.

Para apoiar o processo de qualificação das regiões/microrregiões e garantir os recursos per capita para o financiamento dos procedimentos mínimos da média complexidade, a União adicionará recursos ao Limite Financeiro dos Estados, conforme definido em Portaria específica, sendo que a destinação destes recursos estará descrita na PPI dos Estados e do Distrito Federal, devendo sua incorporação ao Limite Financeiro dos Estados ocorrer na medida em que forem efetivadas as qualificações das regiões/microrregiões assistenciais.

Desta feita, serão qualificadas ${ }^{221}$ apenas as regiões/microrregiões nas quais a PPI estadual tenha definido a alocação dos recursos destinados ao financiamento dos

\footnotetext{
${ }^{220}$ Esse conjunto mínimo de serviços de média complexidade é detalhado no Anexo 3 da NOAS 01/02.

221 Observe-se que a qualificação de uma microrregião deve ser homologada na CIT.
} 
procedimentos mínimos da média complexidade no Município(s)-sede(s) do módulo(s) assistencial(ais). Nas microrregiões não qualificadas, o financiamento desses procedimentos continuará sendo feito de acordo com a lógica de pagamento por produção, intermediado pelo respectivo Estado.

Em assim sendo, o repasse, fundo a fundo, dos recursos para a cobertura dos vários grupos jurisdicionais de consumidores-eleitores de uma dada microrregião estará condicionado à “(...) qualificação da referida microrregião na assistência à saúde, a qual compreende o reconhecimento formal da constituição das regiões/ microrregiões, da organização dos sistemas funcionais de assistência à saúde e dos contratos firmados entre o Estado e os Municípios componentes dos módulos assistenciais, para a garantia do acesso de toda a população residente nestes espaços territoriais a um conjunto de ações e serviços correspondente ao nível de assistência à saúde relativo ao M1, acrescidos de um conjunto de serviços com complexidade acima do módulo assistencial, de acordo com o definido no PDR” $\quad$ (NOAS-SUS 01/02).

Observe que o volume de transferencias financeiras para o financiamento dos procedimentos destinados à cobertura da população do Município-sede de dado módulo, deverá ser acrescido para a cobertura da população residente nos outros Municípios envolvidos na mesma microrregião. As transferencias ocorrem, então, por uma das seguintes formas: fundo a fundo ao Estado habilitado quando o Municípiosede de módulo for habilitado apenas em GPAB-A ou, fundo a fundo ao Municípiosede de cada módulo assistencial quando esse for habilitado em Gestão Plena do Sistema Municipal de acordo com as Normas Operacionais da Assistência à Saúde 01/01 e 01/02, sendo que, obviamente, a parcela relativa à população residente nos Municípios próximos estará condicionada ao cumprimento dos Termos de Compromisso para a Garantia de Acesso.

\subsection{1. das ações de média complexidade e/ou custo}

Para os serviços referentes à Atenção de Média Complexidade (MC), os quais compreendem um conjunto de ações e serviços ambulatoriais e hospitalares cuja oferta 
não se justifica em todos os Municípios, excetuando-se as ações mínimas da média complexidade (M1), que devem ser garantidas no âmbito dos módulos assistenciais, as demais ações assistenciais de média complexidade, tanto ambulatoriais como hospitalares, podem ser garantidas no âmbito microrregional, regional ou mesmo estadual, de acordo com o tipo de serviço, a disponibilidade tecnológica, as características do estado e a definição no Plano Diretor de Regionalização do Estado.

Observe-se que neste caso, em especial, é imprescindível a coordenação do Estado, embora os subsídios à organização e à programação da média complexidade sejam descritos em instrumento a ser acordado pelas três esferas de governo e definidos em Portaria do MS.

Quanto ao processo de Programação Pactuada e Integrada (PPI), este pode ser considerado um dos principais instrumentos de coordenação instituídos aos Estados, ao mesmo tempo em que, ao institucionalizá-la, a União buscou ampliar a garantia de acesso a todos os grupos jurisdicionais de consumidores-eleitores aos serviços de média complexidade, ainda que estes não estivessem disponíveis em seu Município de residência.

Assim sendo, cada Estados passaria a ter que orientar a alocação de recursos voltados às ações ambulatoriais de média complexidade e, a ter que definir limites financeiros $^{222}$ para todos os Municípios em sua jurisdição, independente de sua condição de gestão ${ }^{223}$. Desta feita, a Programação Pactuada e Integrada, uma vez aprovada pela Comissão Intergestores Bipartite (CIB), norteia a burocracia estadual na alocação de recursos federais voltados à assistência entre Municípios. Esses recursos poderão estar sob gestão municipal, quando o Município encontrar-se em GPSM, ou sob gestão estadual, quando o Município estiver em outra condição de gestão.

Observe-se que os Limites Financeiros da Assistência por Município deverão ser definidos globalmente em cada Estado a partir da aplicação de critérios e

\footnotetext{
222 A NOAS 01/02 define limite financeiro da assistência por Município como o montante máximo de recursos federais que poderá ser gasto com o conjunto de serviços existentes em cada território municipal, sendo composto por duas parcelas separadas: recursos destinados ao atendimento da população própria e recursos destinados ao atendimento da população referenciada de acordo com as negociações expressas na PPI.
} 
parâmetros de programação ambulatorial e hospitalar, respeitado o Limite Financeiro Estadual, bem como da definição de referências intermunicipais na PPI. Dessa forma, o limite financeiro por Município deve ser gerado pela programação para o atendimento do próprio jurisdicional de consumidores-eleitores, deduzida da necessidade de encaminhamento para outros Municípios e acrescida da programação para atendimento de referências recebidas de outros Municípios.

Ressalte-se que a alocação de recursos para as ações intermunicipais, ambulatoriais e hospitalares decorre da Programação Pactuada Integrada (PPI) entre os entes federativos envolvidos e da arquitetura contratual elaborada por meio de Termos de Compromisso de Garantia de Acesso.

\subsection{2. das ações de alta complexidade e/ou custo}

Finalmente, quanto aos procedimentos de alta complexidade, a NOAS 01/02 reserva à União a responsabilidade sobre esta política, por meio das seguintes atribuições: a definição de normas nacionais; o controle do cadastro nacional de prestadores de serviços; a vistoria de serviços, quando the couber, de acordo com as normas de cadastramento estabelecidas pelo próprio Ministério da Saúde; a definição de incorporação dos procedimentos a serem ofertados à população pelo SUS; a definição do elenco de procedimentos de alta complexidade; o estabelecimento de estratégias que possibilitem o acesso mais equânime diminuindo as diferenças regionais na alocação dos serviços; a definição de mecanismos de garantia de acesso para as referências interestaduais, através da Central Nacional de Regulação para Procedimentos de Alta Complexidade; a formulação de mecanismos voltados à melhoria da qualidade dos serviços prestados; e o financiamento das ações.

Portanto, a garantia de acesso aos procedimentos de alta complexidade é de responsabilidade solidária entre a União e os Estados e Distrito Federal, de tal forma que cada Estado possa ter sua própria política de alta complexidade/custo, desde que

223 Observe-se que atribuição não reduz o limite financeiro de cada Município voltado às ações der atenção básica, cujo parâmetro é um valor "per capita” definido por Estado. 
vinculada à política nacional, sendo consideradas intransferíveis as funções de definição de prioridades assistenciais e programação da alta complexidade atribuídas à União.

No entanto, a NOAS-SUS 01/02, no que diz respeito à regulação da referência intermunicipal de alta complexidade atribui essa responsabilidade aos Estados. Além disso, determina que os Municípios que tiverem em sua jurisdição serviços de alta complexidade ou alto custo, quando habilitados em Gestão Plena do Sistema Municipal, deverão desempenhar as funções referentes à organização dos serviços de alta complexidade em sua jurisdição, visando a assegurar o comando único sobre os prestadores. Por outro lado, se esse Município não se encontrar na condição de Gestão Plena do Sistema Municipal nos termos da NOB 01/96, essa responsabilidade permanece atribuída à burocracia estadual.

As ações de alta complexidade e as ações estratégicas serão financiadas de acordo com Portaria do Ministério da Saúde, por meio da qual, definirá os valores de recursos destinados ao custeio da assistência de alta complexidade para cada Estado. E caberá aos Estados, de acordo com a PPI e dentro do limite financeiro estadual, prever a parcela dos recursos a serem gastos em cada Município para cada área de alta complexidade, destacando a parcela a ser utilizada com a população do próprio Município e a parcela a ser gasta com a sua população de referência.

\subsection{3. da coordenação do sistema}

Também com a NOAS-SUS 01/02, o Ministério da Saúde assume expressamente a coordenação nacional do processo de programação da assistência à saúde. Como mecanismo de monitoramento, as Secretarias de Saúde dos Estados e do Distrito Federal deverão encaminhar ao Ministério da Saúde uma versão consolidada da Programação Pactuada e Integrada (PPI), conforme definido em Portaria do Ministério da Saúde. E, uma vez que divide a coordenação com as Secretarias de Saúde Estaduais, estas poderão dispor de instrumentos próprios de programação adequados às suas 
especificidades, respeitados os princípios gerais e os requisitos da versão consolidada a ser enviada ao Ministério da Saúde.

Além disso, os mecanismos de monitoramento dos Estados, segundo a NOAS-SUS 01/02, devem assegurar que a alocação de recursos se vincule aos serviços prestados e não à capacidade de oferta dos prestadores de serviços; que a operacionalização de mecanismos que regulem a oferta e a demanda de serviços, organizem os fluxos e, garantam o acesso universal às referências; e, que as responsabilidades de cada Município sejam condizentes com suas respectivas habilitações.

\section{5. as transferências financeiras - incentivo às normatizações do SUS}

Vimos que antes do SUS, a União atuava na área da saúde pública por meio do INPS e, depois, do INAMPS, que eram autarquias do Ministério da Previdência e Assistência Social - MPAS. Nessa época, segundo Brasil (2002b), os indivíduos eram divididos em três grupos quanto à assistência à saúde: “(...) os que podiam pagar; os que tinham direito à assistência prestada pelo INAMPS (trabalhadores com carteira assinada); e os não-contribuintes, estes sem direito algum à saúde” . Também nessa época, a distribuição dos recursos gastos pelo INAMPS entre as regiões do Brasil era bastante desigual, tanto que, segundo Brasil (2002b), em 1987 a região Sudeste recebia $59,28 \%$ dos recursos financeiros, embora com $43,79 \%$ da população nacional.

Por outro lado, se acrescentarmos a esse dado os limites financeiros dos Estados, já na vigência da Constituição de 1988 e da Lei Orgânica da Saúde, ainda, em 1994, havia desigualdades na alocação dos recursos do Ministério da Saúde. Afinal, como já observado, num período em que a NOB 01/91 foi emitida ainda sob a influência da incorporação do INAMPS, justificam-se que os valores atribuídos aos "tetos financeiros" fossem inicialmente estabelecidos em razão da capacidade instalada em cada Estado e, a partir dos dados históricos de gastos na saúde pública registrados pelo INAMPS. É por isso que, encontramos em Brasil (2002b), valores “per capita” como limites financeiros atribuídos desigualmente em 1994 aos Estados, dos quais 
destacamos: Acre e Amapá, com R\$25,00, seguidos do Amazonas com R \$ 26,84, de Roraima com R\$27,49 e de Sergipe com R\$ 28,66, enquanto São Paulo com R \$ 57,78, Paraná com $\mathrm{R} \$$ 53,18 e Rio de Janeiro com $\mathrm{R} \$ 51,78$.

\section{1. estruturando a diversidade de base do financiamento do SUS}

De certa forma, a partir do momento que o SUS começa a ganhar identidade própria com a emissão da NOB 01/93, é que os institutos que regem o financiamento também se alteram, até mesmo em resposta a uma mudança de enfoque quanto à responsabilidade pelo financiamento do sistema de ações e serviços de saúde, em especial, a composição do financiamento municipal para a saúde, levando-se em conta a participação dos três níveis de gestão do SUS. A Lei prevê que o processo de planejamento e orçamento do SUS seja “(...) ascendente, do nível local até o federal, ouvidos seusórgãos deliberativos, compatibilizando-se as necessidades da política de saúde com a disponibilidade de recursos em planos de saúde dos Municípios, dos Estados, do Distrito Federal e da União” (art. 36, Lei 8.080/90).

Porém, somente com a NOB-96, que se alinha ao preceito constitucional de que a Saúde faça parte integrante da Seguridade Social, juntamente com a Previdência e a Assistência Social (art. 194, CF 88), é que fica claro o aspecto cooperativo entre as três esferas de governo, atribuindo a cada uma o dever de assegurar um aporte regular de recursos aos respectivos fundos de saúde, em atenção a outro preceito constitucional, que estabelece a "diversidade dabase de financiamento" do SUS (inciso IV, art. 194, CF 88).

Dessa forma, a base de financiamento do SUS é, ou foi, composta dos encargos sobre a folha de salários (atualmente repassada de modo integral ao INSS), do COFINS (sobre o faturamento), do CSLL (sobre o lucro líquido), e de alguns outros recursos provenientes de impostos e taxas (atualmente destinados a despesas com pessoal e encargos sociais). Mais recentemente, incluiu-se a receita proveniente da contribuição (ex-provisória) de movimentações financeiras. 
A Lei determina que os recursos do SUS sejam destinados conforme a receita prevista em alguns orçamentos de responsabilidade da União, entre eles o Orçamento da Seguridade Social (art. 31, Lei 8.080/90). Tal atribuição deve ocorrer através de proposta elaborada pela Direção Nacional do SUS, com vistas a atender metas e prioridades estabelecidas na Lei de Diretrizes Orçamentárias.

A administração desses recursos é atribuída, por Lei, ao Ministério da Saúde através do Fundo Nacional de Saúde, os quais devem ser repassados, como já visto, de forma "regular e automática" , fundo a fundo, em razão da execução de ações e serviços de saúde de competência dos Estados e principalmente Municípios $\left(\S 1^{\circ}\right.$, art. 33, Lei 8.080/90). Esses recursos recebidos a título de transferência deverão ser previstos nas respectivas peças orçamentárias, monitorados pelo Sistema Nacional de Auditoria, auditados pelos Tribunais de Contas e, movimentados sob a fiscalização dos respectivos Conselhos de Saúde.

Nas esferas estaduais e municipais, os recursos transferidos pela União/Estados devem ser dotados e identificados nos respectivos Orçamentos Públicos e nos Fundos de Saúde como receita operacional proveniente da esfera federal e/ou estadual e utilizados na execução de ações previstas nos respectivos planos de saúde e na programação pactuada e integrada (PPI - programação que traduza as responsabilidades de cada Município com a garantia de acesso da população aos serviços de saúde, envolvendo todas as atividades previstas no plano de atenção básica, quer pela oferta de serviços existentes no próprio Município, quer pelo encaminhamento a outro, sempre por intermédio de relações entre gestores municipais, mediadas pelo gestor estadual ).

Além disso, as transferências da União são condicionadas à contrapartida dos níveis de governo destinatários, em conformidade com suas normas legais vigentes (Lei de Diretrizes Orçamentárias e outras), na forma de recursos financeiros de seus respectivos Tesouros, os quais devem ser dotados em suas peças orçamentárias ao lado das transferências previstas.

Quanto aos reembolsos das despesas realizadas em função de atendimentos prestados por unidades públicas a beneficiários de planos privados de saúde, por se constituir em fonte adicional de recursos, atribui-se aos Estados e Municípios a 
viabilização de estrutura e mecanismos operacionais para a arrecadação desses recursos e a sua destinação exclusiva aos respectivos Fundos de Saúde.

Já quanto aos recursos para investimentos, estes serão alocados pelo Ministério da Saúde mediante a apresentação pela Secretaria Estadual de Saúde da programação de prioridades de investimentos, devidamente negociada na Comissão de Intergestores Bipartite e aprovada pela Comissão de Intergestores Tripartite, sempre até o valor estabelecido no orçamento do Ministério. A NOB-96 também previa a criação de Câmaras de Compensação para o pagamento de serviços de referência, entre os entes federativos.

Com relação aos critérios de financiamento, e no intuito de solucionar algumas de suas distorções com a enorme diversidade municipal de capacidades ao atendimento às disposições normatizadas pelas NOB's, o Ministério da Saúde também se manifesta com a emissão da NOB-96, em especial no seu item 12, para esclarecer que os recursos de custeio da esfera federal, destinados à assistência ambulatorial e hospitalar, configuram o chamado Teto Financeiro de Assistência (TFA) e, os seus valores podem ser executados segundo duas modalidades: transferência regular e automática (fundo a fundo) e/ou remuneração por serviços prestados.

Esclarece-se que a transferência regular e automática fundo a fundo se consistirá na transferência de valores diretamente do Fundo Nacional de Saúde aos demais, independente de convênio ou instrumento congênere, segundo as condições estabelecidas na NOB-96, e destinadas basicamente ao custeio de procedimentos e ações de assistência básica podendo ser majorados em função de atendimentos a programas de saúde da família (PSF) e de agentes comunitários de saúde (PACS).

Esta regra de majoração é no intuito de se manter o devido cuidado com a diversidade entre regiões e locais, através da atribuição de parâmetros que considerem a proporção da população coberta por esses programas, por Município, limitando, portanto, a definição de uma prioridade de nível nacional (a não ser situações de risco epidêmico, como nos casos de cólera e dengue).

O piso assistencial básico (PAB) definido pela NOB-96 consiste de recursos financeiros ao custeio de procedimentos e ações básicas tipicamente municipais, quantificado pela multiplicação de um "valor per capita nacional" pela população do 
Município, podendo então ser majorado por uma parte variável em função do percentual populacional já coberto pelos dois programas acima mencionados. Seu resultado era então transferido ao Fundo de Saúde municipal se este já estiver habilitado ao SUS, ou sob a administração da Secretaria Estadual correspondente quando não habilitado.

Porém, em 1997, através de Portaria ministerial, o Governo Federal cria o então chamado Piso de Atenção Básica, ampliando a ênfase em ações preventivas e também objetivando reduzir disparidades nos repasses aos Municípios com diferentes estruturas de prestação de saúde, tanto em capacidade de atendimento, quanto em qualidade nos procedimentos ambulatoriais ou hospitalares. Essa Portaria de n. ${ }^{\circ}$ 1.882/97 do Ministro da Saúde define um outro conjunto de mecanismos de redistribuição de recursos financeiros, que visam incentivar as ações básicas coletivas e preventivas, que se encontravam prejudicadas pela vinculação de repasses dos recursos financeiros do SUS à produção física das estruturas de prestação de serviços, as quais se concentram nas ações curativas.

A Portaria MS n. ${ }^{\circ}$ 1.882/97 manteve a lógica da NOB-96, que instituiu a partição dos recursos financeiros dirigidos ao SUS, reservando uma parcela específica a ser distribuída conforme a população dos Municípios e vinculada exclusivamente ao custeio de procedimentos de atenção básica. Porém refez a composição de seus valores da seguinte forma: uma parte fixa ${ }^{224}$, e duas variáveis. Uma delas relativa a incentivos para o desenvolvimento de ações no campo específico da atenção básica e a outra se destina a incentivar ações básicas de vigilância sanitária, epidemiológica e ambiental, à assistência farmacêutica básica, aos programas de agentes comunitários de saúde, de saúde da família, de combate às carências nutricionais, e outros que venham a ser, posteriormente, agregados.

Os Municípios já habilitados à condição de gestão autônoma foram beneficiados com o novo repasse de imediato, enquanto os demais passariam a recebêlo, a medida em que fossem se integrando a dois sistemas de informação: Sistema de

${ }^{224}$ Em 1998, essa parte fixa era estipulada em R\$ 10,00 / habitante / ano (fonte: "site” do MS). 
Informações Ambulatoriais (SIA/SUS) e o Sistema de Informações Hospitalares (SIH/SUS).

O não fornecimento dessas informações suspende o repasse desses recursos, pois, a rotina dessas informações visa avaliar as políticas de investimento no setor, objetivando a distribuição de recursos com equidade federativa. Com o PAB, todos os Municípios, inclusive aqueles mais pobres e alijados dos recursos do SUS, às vezes sem estrutura hospitalar ou mesmo ambulatorial, passam a ter condições de realizar programas de ações básicas de prevenção e educação para a saúde.

Embora o PAB reduza as discrepâncias dos repasses considerados "per capita" entre Municípios habilitados ao SUS e os que se encontravam em maiores dificuldades, há que se observar que o volume de recursos não é ilimitado, pois, com a elevação do valor "per capita" da parte fixa do PAB, influi-se na redução proporcional dos recursos destinados à remuneração por serviços produzidos, entre eles, os das complexas estruturas hospitalares localizadas nos grandes centros urbanos, gerando novas motivações por barganhas políticas.

Mais recentemente, foi promulgada em 13 de setembro de 2000, a Emenda Constitucional n. 29 (PEC da Saúde), que impõe como inadiável o financiamento estável das ações de saúde pública empreendidas pelas três esferas de governo no âmbito do SUS, e gradativamente elevado até o nível fixado como meta para o exercício fiscal de 2004.

Na mesma oportunidade, o Conselho Nacional de Saúde elencou algumas diretrizes para a sua aplicabilidade, objetivando subsidiar a regulamentação da autoaplicação da Emenda, em especial do seu art. $7^{\circ}$, com base nas disposições das Leis 8.080/90 e 8.142/90, e nas Normas Operacionais Básicas e, subsidiar a elaboração da Lei Complementar requerida no $§ 3{ }^{\circ}$ do art. 198 da Constituição Federal, alterado pelo art. 6. ${ }^{\circ}$ da Emenda.

Entre essas diretrizes tem-se que são parâmetros básicos da regulamentação dos serviços públicos de saúde os princípios da universalidade, da eqüidade, da integralidade, da descentralização com hierarquização e regionalização de estruturas de serviços e controle social, priorizando a regressão das disparidades macrorregionais, estaduais, microrregionais e municipais. Além disso, que uma nova norma operacional 
seria elaborada e aprovada conjuntamente pelas direções únicas ${ }^{225}$ do SUS nas três esferas de Governo, disciplinando, entre outras medidas: a organização e o funcionamento das estruturas hierarquizadas e regionalizadas de serviços.

Essas estruturas regionalizadas deveriam atuar com total prioridade para a acessibilidade e a alta resolutividade das ações e serviços da Atenção Básica à Saúde, com solidariedade a toda a clientela, estabelecendo um vínculo responsável de suas equipes de saúde junto aos grupos familiares e a outros agregados populacionais.

Além disso, deveriam também observar a plena municipalização e microrregionalização das ações e serviços básicos de saúde e os de média complexidade; a elaboração de metas de investimentos estratégicos em capacidade instalada de serviços de média e alta complexidade, e de fixação de profissionais especializados, em Municípios-pólo de regiões menos desenvolvidas, em função do acesso e eqüidade da atenção integral à saúde, em cotejo com deslocamentos interregionais e interestaduais de usuários; a definição de metas de elevação dos "percapitas" financeiros de custeio em todas as regiões, e de regressão das disparidades macrorregionais, estaduais e microrregionais, com definição das contrapartidas das três esferas e em congruência com o disposto nos itens anteriores. Enfim, essas estruturas regionais deveriam adotar uma postura regulamentada voltada às interações intermunicipais para o serviço publico de saúde.

Uma outra diretriz ajustada é a que se refere aos recursos federais destinados às transferências verticais, vinculados à regionalização, seriam pelo menos $50 \%$ repassados segundo o quociente populacional, até a promulgação da lei complementar requerida no art. 198, alterado pelo art. $6^{\circ}$ da Emenda.

Finalmente, uniformizaram-se as interpretações a cerca desta Emenda Constitucional, em especial, quanto à auto-aplicação imediata de seu art. $7^{\circ}$, referente ao cálculo da variação nominal do PIB sobre as receitas tributárias auferidas sobre as seguintes bases tributárias: art. 155, 157 e 159 da CF 88 para os Estados e DF, e aos art. 156, 158 e 159 para os Municípios. Ou seja, no caso especifico dos Municípios, até o

\footnotetext{
${ }^{225}$ A direção única do SUS nas três esferas de governo está organizada por meio do Ministério da Saúde, do Conselho Nacional de Secretários Estaduais de Saúde e do Conselho Nacional de Secretários Municipais de Saúde.
} 
ano 2004, deverão estar aplicando em ações e serviços públicos de saúde, no mínimo, 15\% da soma das seguintes receitas: Imposto Sobre Serviços de Qualquer Natureza, Imposto Predial e Territorial Urbano, Imposto de Transmissão Inter Vivos e, Imposto de Renda incidente na fonte sobre rendimentos pagos, inclusive por suas autarquias e fundações.

O consenso ${ }^{226}$ estabelecido nessa oportunidade foi o de que no início de vigência dessa emenda constitucional, que acabou sendo o ano de 2000, a aplicação deveria ser de pelo menos $7 \%$ da receita líquida das receitas tributárias nas ações e serviços de saúde. Isto é, $7 \%$ da totalidade da receita dos impostos, deduzidos a parcela transferida e, acrescida da parcela recebida de outras esferas de Governo, deveriam, no mínimo, ser dirigido à política pública de saúde ainda no ano $2000^{227}$.

A partir de 2001, todos os entes federativos, devem, no mínimo, manter a progressividade de pelo menos 1/5 da diferença por ano, até a meta no ano de 2004, de pelo menos 12\% para os Estados e DF, e de pelo menos 15\% para os Municípios. Essa explícita progressividade, de certa forma, elimina qualquer possibilidade de qualquer diminuição do percentual aplicado nas ações e serviços de saúde, nos casos em que o ente federativo estiver com seu percentual acima do mínimo no atual exercício vigente e abaixo da meta determinada para 2004.

As transferências do Ministério da Saúde às Secretarias de Saúde dos Estados, DF e Municípios, e das Secretarias de Saúde dos Estados às Secretarias de Saúde dos Municípios, estão excluídas da base de cálculo dos recursos aplicados nas ações e serviços de saúde, de acordo com as disposições da E.C, bem como da despesa. Não devem também constar da base de cálculo dos recursos aplicados nas ações e serviços de saúde, as despesas com: ações de saneamento financiadas com tarifas, taxas ou contribuições de melhoria cobradas dos usuários; serviços de limpeza urbana ou

\footnotetext{
${ }^{226}$ Segundo o Ministério da Saúde, para a especificação desta diretriz envolveram-se as Secretarias Estaduais, o Conselho Nacional de Saúde, a Consultoria Legislativa e a de Orçamento e Finanças, ambas da Câmara Federal, o Ministério da Saúde, o IPEA e, o Ministério Público.

227 Para os Estados e Municípios que se encontravam com aplicação abaixo de $7 \%$ na data da promulgação da E.C., deveriam orçamentar o ano 2001 prevendo pelo menos 8\% para os Estados e 8,6\% para os Municípios, correspondentes ao primeiro incremento de pelo menos $1 / 5$ da diferença por ano, previsto no $\S 1 .^{\circ}$ do art. $7 .^{\circ}$ da E.C.
} 
rural e tratamento de resíduos sólidos, financiados com tarifas, taxas ou contribuições de melhoria cobradas dos usuários; dívida pública; inativos e pensionistas; ações financiadas com transferências voluntárias recebidas da União ou Estado (SUS, Saneamento e outros).

Portanto, os mínimos percentuais por exercício, que expresse a participação dos serviços de saúde pública sobre o total dos orçamentos públicos dos Estados e Municípios, são, respectivamente, os seguintes: 2000 (7\% e 7\%), 2001 (8,6\% e 8\%), 2002 (10,2\% e 9\%), 2003 (11,8\% e 10\%) e, 2004 (15\% e 12\%).

\section{2 - a programação pactuada integrada - PPI}

Um critério de financiamento é a Programação Pactuada e Integrada - PPI, inicialmente proposta pela NOB-96, passou a ser aplicada às ações de média e alta complexidade com a NOAS-SUS 01/01. No entanto, antes da NOAS-SUS 01/01, a realização das PPI $^{228}$, bem como a definição dos limites financeiros municipais para custeio, segundo Brasil (2002b), não tinha seus valores fixados claramente pela maioria dos Estados, assim como não havia como demonstrar quais eram os critérios ou parâmetros que definiam a alocação dos recursos financeiros, Município a Município.

Apesar da implantação da PPI poder reverter a lógica inicialmente instituída de se remunerar a oferta, pela lógica de se financiar a necessidade da população, segundo Brasil (2002b) observou-se na maioria das burocracias estaduais e municipais, algumas dificuldades na implantação desse processo. A reação da União, face à situação apresentada, se dá com o desenvolvimento de um instrumento informatizado, colocado a disposição dessas burocracias, a fim de facilitar a implantação da NOASSUS 01/01 e, proporcionar um sistema de regulação e controle que ampliasse a capacidade de monitoramento, principalmente, das burocracias estaduais. A existência

\footnotetext{
${ }^{228}$ A Programação Pactuada e Integrada - PPI norteia-se pelo princípio de integralidade das ações e busca garantir o princípio da eqüidade. Contempla a alocação dos recursos e explicita as responsabilidades de financiamento de custeio da assistência das três esferas do governo, de forma a garantir o acesso da população a ações e serviços de saúde no próprio município ou em outros municípios que ofertam o serviço mediante encaminhamento formalizado e negociado anteriormente entre os gestores respectivos.
} 
desse instrumento $^{229}$, segundo Brasil (2002b), permitiu que as burocracias estaduais mantivessem uma programação continuada, estabelecida em critérios uniformes, dadas as contínuas mudanças nas estruturas municipais assistenciais e nos fluxos de referência intermunicipal dos consumidores-eleitores residentes numa determinada região.

De qualquer forma, segundo Brasil (2002b), observou-se ao longo dos anos 2001 e 2002 um “(...) grande dinamismo nos processos de articulação entre as burocracias estaduais e municipais para a elaboração dos planos diretores de regionalização, de investimentos e da programação pactuada e integrada, no âmbito das respectivas $C I B$ ”.

No entanto, essas negociações na CIB continuaram a apresentar algumas dificuldades, principalmente, na definição da alocação regional dos recursos, envolvendo a definição de prioridades entre os Municípios envolvidos, e na definição dos parâmetros. Em especial, Brasil (2002b) afirma que essas dificuldades na definição dos parâmetros, quase sempre ficavam mais intensas no “(...) momento da consolidação final das metas físicas e financeiras e das referências intermunicipais” . De qualquer forma, essas dificuldades revelavam os conflitos de natureza política existentes entre as respectivas elites políticas e, além disso, as "insuficiências técnicas" de algumas burocracias estaduais também impediram o desenvolvimento das programas durante o ano de 2002 em alguns Estados.

De qualquer forma, os parâmetros assistenciais foram objeto de reformulação em todos os Estados como conseqüência do processo de implantação da Programação Pactuada e Integrada - PPI. A transparência dos critérios de alocação dos recursos do SUS e a busca de sua distribuição equânime foram alguns dos principais objetivos que motivaram a União a rever os processos de descentralização e de regionalização da assistência. Ressalte-se que ambas as NOAS-SUS estabeleceram que "os limites financeiros da assistência por Município devem ser definidos globalmente em cada

\footnotetext{
${ }^{229}$ Vale ressaltar que esse instrumento informacional, quando aplicado aos casos de média complexidade, incorpora o conceito de "bandas paramétricas", o que permite às burocracias estaduais analisar a sua respectiva série histórica, bem como, visualizar sua posição em relação à situação nacional. Também possibilita simular os impactos financeiros dos parâmetros adotados e seu balizamento com os recursos previstos inicialmente no módulo de "macro alocação". Segundo Brasil (2002b), a utilização das "bandas” permite a “(...) análise e utilização mais adequada das séries históricas, abolindo-se a prática usual da adoção de parâmetros tomados pelas médias históricas de concentração per capita”
} 
Estado a partir da aplicação de critérios e parâmetros de programação

ambulatorial e hospitalar, respeitado o limite financeiro estadual, bem como da definição das referências intermunicipais na PPI” .

É por isso que, diante do estágio atual do SUS, percebe-se a União na necessidade de ampliar sua capacidade de monitoramento de todo o sistema saúde a nível nacional, mas sem se descuidar de alguns de seus problemas de assimetria informacional, que minimizados reduziriam os custos de transação e de monitoramento. Dentre eles destaca-se que a União, no cálculo dos valores a serem adotados como parâmetros pelos Estados, deveria respeitar tanto as necessidades, quanto os recursos federais a transferir que comporão o limite financeiro do Estado. O que nos remete a uma outra consideração complementar: que a União também deveria procurar se manter informada das diferentes disponibilidades de recursos orçamentários próprios dos Estados e Municípios comprometidos com na oferta de serviços de saúde pública, se pretende o exercício eficiente da coordenação do financiamento integrado das ações do SUS e, que a sua fonte se mantenha devidamente diversificada.

\section{6. as dificuldades dos Municípios em se adequar às normas dos SUS}

Aqui é interessante observar que entre os mais de 5.000 Municípios existentes na federação brasileira, com certeza, poderíamos atribuir à sua maioria uma baixa capacitação técnica de suas administrações, inclusive, na elaboração de seus orçamentos e balanços, notadamente os de pequeno porte, pobres ou, muito provavelmente, entre aqueles classificados como "latentes". Se verdade, então cada uma dessas elites políticas municipais teria limitada a sua informação na tomada de decisão a cerca do volume dos recursos investidos, da forma dos gastos e dos resultados a se obter, com consequiência na eficiência esperada com que a União desenvolve suas funções redistributiva e alocativa.

Com isso, acentuam-se as desigualdades regionais, à medida que essas questões internas limitam a elevação desses Municípios à condição de gerenciadores do SUS em seu próprio território e, portanto, não credenciados a receber, fundo a fundo, a 
transferência de recursos financeiros vinculados às ações de saúde. Afinal, o Município que auferir a condição de autonomia na gestão do SUS em seu território é responsabilizado pela prestação de todos os serviços, tomados como condição mínima para a sua condição de homologação, incluindo-se aqueles serviços oferecidos pelo setor privado.

É para essa situação que as elites políticas municipais avaliam uma tomada de decisão sobre o seu credenciamento, situação essa que certamente envolve a necessidade de desenvolvimento de controles e, de alguma habilidade na gestão da "coisa pública". Essas responsabilidades são atribuições conferidas com a sujeição do Município a critérios de adequação conferidos pelas NOB's, das quais, em especial a NOB 01/93, estabelecia que ante a intenção do Município à condição de gestão semiplena, deveria este considerar sua capacidade de resposta ao cálculo do montante a ser repassado, em função do volume de serviços prestados no exercício anterior (ano de 1992), da população, da capacidade potencial de produção segundo recursos físicos e humanos existentes e do grau de complexidade da estrutura de prestação de serviços.

Portanto, além da capacidade de gestão, também se impôs ao ente federativo municipal uma capacidade de barganha política pela sua programação física e orçamentária, cuja solução envolve Estados e Municípios em meio a uma arena de negociação conhecida por Comissão Intergestora Bipartite (CIB), cujo resultado, na sequiência, se submete à aprovação dos respectivos Conselhos de Saúde (Heimann, 1998). Ou seja, são atribuições que se encontram fora do alcance de muitos dos Municípios brasileiros.

È por isso que pelo menos até a Emenda Constitucional 29, de 2000, era possível se antever dificuldades na formatação do sistema de financiamento do SUS. Além dos Municípios serem majoritariamente dependentes da União (em média, cerca de $75 \%$ do volume total destinado à saúde pública), o repasse desses recursos fundo a fundo, até o advento da NOB-96, ocorria sem qualquer sistema de controle que garantisse a devida avaliação das políticas, uma vez que era efetuado diretamente aos prestadores públicos e privados. Esta rotina ocorria desde que o valor a ser repassado estivesse previamente aprovado pelas Secretarias Municipais de Saúde, num momento em que muitas delas não tinham condições técnicas de controlar o tipo, a quantidade ou 
a qualidade dos serviços prestados, em geral, pelo setor privado (Abrucio e Costa, 1998).

Note-se que esta forma de condicionar o repasse de recursos financeiros à execução de ações padronizadas centralmente tem como referência uma relação contratual, em que o principal (contratante), com objetivos específicos, contrata agentes que devem implementar tais objetivos. Estes agentes tanto podem compartilhar os objetivos do principal quanto ter seus próprios objetivos, sendo induzidos a revelá-los. O principal procura assegurar que seus objetivos sejam atingidos através de condicionantes financeiros (incentivos), instrumentalizados pelas transferências.

Ou seja, a União, por meio do Ministério da Saúde, se coloca na posição de principal (contratante), condicionando o repasse de recursos financeiros ao cumprimento de condições previamente normatizadas que induzem os Municípios a focarem em seus próprios objetivos. Evidentemente, esse mecanismo de governança busca moldar e limitar as escolhas das elites políticas municipais e o comportamento das burocracias municipais (os contratados). No mínimo um relacionamento interessante, se não estranho, quando o atribuímos a entes federados que deveriam ser dotados de autonomia.

Outros problemas vêm se acumulando no relacionamento entre os três entes federativos. Entre eles o que surgiu com a ascensão de Municípios à condição de gestão semiplena nos termos da NOB 01/93, onde as transferências da União diretas aos Municípios representam às Secretarias Estaduais de Saúde uma certa queda de poder político, ocasionando inclusive "represálias" na forma de "estímulos, por parte das Secretarias Estaduais de Saúde, a que os demais Municípios não habilitados se utilizassem os serviços de saúde dos Municípios em gestão semiplena” (Heimann, 1998).

Portanto, o que se depreende é que os problemas do SUS são basicamente de duas origens: capacidade de financiar o sistema e as interações políticas entre os entes federativos envolvidos. Porém, além desses grupos de problemas detectados, destacam-se outros de assimetria informacional, afinal, segundo Abrucio e Costa (1998), muitas das elites políticas municipais desconheciam que o gerenciamento do 
processo de descentralização deveria ocorrer nas Comissões Intergestoras Bipartites (CIB) por meio de um planejamento integrado.

Tal fato caracteriza a indisponibilidade dos gestores estaduais em coordenar o modelo de descentralização inicialmente idealizado pelo SUS e, institucionalizado pelas sucessivas edições de NOB`s. Como conseqüência, as elites políticas municipais, além de recorrerem a "outras consultorias públicas e privadas" , acabavam elaborando projetos que visavam apenas a captura de recursos financeiros junto à União, faltandolhes a noção de metas e a consideração de indicadores de avaliação do impacto das ações (Abrucio e Costa, 1998).

Em meio a isso, a exigência colocada ainda com a NOB 01/93, de que os planos de saúde fossem aprovados pelos respectivos Conselhos de Saúde, passa a ser mais uma retórica burocrática do que o produto de uma discussão oriunda da participação da sociedade, prevista constitucionalmente como diretriz do SUS. A NOB 01/93 também possuía uma outra exigência: os chamados relatórios de gestão, os quais eram realizados sem qualquer padronização quanto a conteúdos e formatos.

Essa ausência de padronização dos planos de saúde e de relatórios de gestão, comprometeu o desempenho dos gestores na área de saúde, de tal sorte que "sem sistema de informação adequado, o Ministério da Saúde e as Secretarias Estaduais de Saúde não estavam capacitados a desempenhar seu papel de reguladores do sistema em seu nível de governo e tampouco poderiam os Conselhos de Saúde exercer o controle público sobre a definição e execução das políticas para o setor” (Heimann, 1998).

De qualquer forma, o que se observou durante esse período é que as mudanças ocorridas ainda no modelo de descentralização estrita suscitaram alguns problemas para a implementação do SUS, acentuando ao final da década de 1990, o debate entre os envolvidos na constatação de que o então vigente modelo se esgotava. Dentre os problemas, destaca-se de imediato, que a divisão de responsabilidades entre Estados e Municípios passava, gradativamente, a se dar nos termos de pactos de gestão estabelecidos entre eles cujos critérios muitas vezes não estavam previstos pelas normas da organização SUS, embora a NOB-SUS 01/96 permitisse, segundo Brasil (2002b), que “(...) acordos regionais aprovados nas CIB's sobrepujassem alguns dos 
dispositivos da própria norma, como a exigência de comando único do sistema em cada nível”.

No processo de habilitação, também se acharam alguns problemas, pois, como já observado, em alguns casos, a habilitação dos Municípios às condições estabelecidas pelas várias NOB's que se sucederam pela década de 1990, deram-se apenas formalmente. Por outro lado, essa formal habilitação dos Municípios em Gestão Plena da Atenção Básica teve um efeito positivo: possibilitou a responsabilização de milhares de elites políticas municipais, posteriormente facilitando a aplicação de políticas alocativas por meio da implantação do Plano de Atenção Básica - PAB.

No entanto, embora passasse a ser possível responsabilizar um número maior de elites políticas municipais por não se enquadrarem nas condições de atenção básica, segundo Brasil (2002b), não se conseguiu assegurar a qualidade desses serviços básicos prestados e, nem se garantiu que os respectivos grupos de consumidores-eleitores acessassem os serviços de maior complexidade. Além disso, mais recentemente, entre aqueles Municípios que se habilitaram à Gestão Plena do Sistema Municipal, alguns deles embora passassem a dispor de maior autonomia de gestão, adotaram um comportamento "monopsônico", não assumindo o papel esperado de referência regional ou estadual de serviços.

Também a assimetria informacional da burocracia do SUS se revela em relação às necessidades de financiamento das ações de saúde pública. Afinal, o SUS, ao incorporar o INAMPS, assume como própria, a lógica de se financiar as ações de saúde pública por critérios pautados na oferta do serviço. Ou seja, enquanto esses critérios praticamente se vinculavam à capacidade instalada existente e às necessidades de receita dos prestadores de serviços de saúde, permaneceram as dificuldades da União de exercer suas funções redistributivas e mesmo alocativas na gestão da política pública de saúde de âmbito nacional.

Observe-se que o modelo de descentralização inicialmente adotado não previa a redistribuição de recursos mais equilibrada entre as regiões em razão de seus respectivos níveis de desenvolvimento. Talvez por isso, a União tenha migrado das normas tipo NOB`s para as NOAS`s a procura de outros instrumentos, além dos financeiros, que estivessem voltados ao fortalecimento da gestão pública do SUS, à 
melhoria do acesso e da qualidade das ações de saúde e, ao estabelecimento de regras que consolidem não só a hierarquização do sistema, mas também a sua regionalização.

Segundo Brasil (2002b), poucos dos Estados que desenvolveram os respectivos processos de Programação Pactuada e Integrada (PPI), conseguiram implementá-los efetivamente. Evidentemente, isso também dificultou a integração intermunicipal. Além de revelar a existência de limitações da capacidade política de alguns Estados exercerem o papel de coordenação das ações de saúde pública, também mantinha o SUS "atomizado" em vários sistemas municipais, com as respectivas elites políticas desenvolvendo barreiras de acesso a consumidores-eleitores de outros grupos jurisdicionais.

Sobre esse tema, é interessante observar diagnóstico elaborado pela União, pelo qual, segundo Brasil (2002b), “(...) a expansão de serviços nas décadas precedentes produziu um conjunto de unidades com oferta desordenada e relações frágeis entre os serviços, dificultando a reorientação do modelo de atenção e a conformação de estruturas regionalizadas e resolutivas que operassem em níveis de escala econômica adequados, com relações custo-benefício favoráveis e suportáveis para o sistema”.

Esse diagnóstico faz referência a serviços prestados em décadas anteriores. Entenda-se nesse contraste, a intenção de uma correlação com as primeiras normas do SUS, que impunham um padrão mínimo e único a todos os Municípios, composto dos chamados procedimentos de atenção básica (Piso de Atenção Básica fixo - PAB fixo). Essa normas desconheciam as desigualdades regionais e não dispunham de qualquer dispositivo que sinalizasse que grupos de consumidores-eleitores, em razão dos respectivos graus de mobilidade, pudessem ter a necessidade de acessar a serviços mais especializados em outras jurisdições, uma vez que esse padrão mínimo apresentava baixa capacidade de resolução de seus problemas de saúde mais. Por vários anos, essas dificuldades de acesso à assistência de média e alta complexidade se mantiveram, até porque, essas ações estavam concentradas em Municípios do tipo "monopsônico", ou mesmo "privilegiado", os quais poderiam até estar situados em outros Estados.

Além disso, o diagnóstico acima, em suas "entrelinhas", embute uma outra informação: a de que não seriam apenas os problemas de informação assimétrica que 
estariam acometendo a burocracia do SUS, na medida em que os problemas de coordenação surgem com as mudanças institucionais com tendência à regionalização. Ou seja, não havia uma avaliação rotineira e sistemática de desempenho e nem um monitoramento das atividades. Em síntese, estabelecia-se a assimetria informacional, na medida em que, tanto a União, quanto a maior parte dos Estados não dispunham de diagnósticos sobre o funcionamento dos sistemas municipais para o desenvolvimento adequado de estratégias de cooperação intermunicipal e nem quanto às decisões de alocação de investimentos, até porque, como já observado, muitos dos Municípios não dispunham de suficiência administrativa para processar e ofertar esses dados.

Um outro fator interessante é o que se refere ao emprego das transferências financeiras enquanto um mecanismo eficiente de incentivo às elites políticas se adequarem às normas do SUS. Brasil (2002b) chama a nossa atenção ao fato de que “(...) o processo de habilitação dos Municípios atingiu seu ápice ao final do ano 2000, sendo residual o número deles que ainda não se encontra em uma das condições de gestão previstas na NOB-SUS 01/96” . Ora, por trás dessa constatação, pode-se inferir a redução do poder das transferências financeiras de incentivar as elites políticas municipais, uma vez que a taxa de crescimento do volume de recursos transferidos fundo a fundo aos Municípios tende a zero, na medida em que todos se enquadrem às normas do SUS.

Evidentemente, esta constatação sinaliza a necessidade de um novo mecanismo, além das transferências financeiras, que mantivesse a municipalização da produção de serviços de saúde pública; ou seja, o sistema estava diante de um esgotamento do modelo inicial de descentralização. Paradoxalmente, na medida em que se elevava o grau de descentralização da política pública de saúde, também se ampliava a necessidade de novas formas institucionais de indução e de aperfeiçoamento do processo de descentralização do sistema. A análise deste paradoxo levou o SUS à formulação e implementação de uma nova mudança institucional: as NOAS's, ou seja, que o modelo de descentralização admitisse a regionalização da prestação dos serviços de saúde pública. 


\section{7. - o SUS estruturando a cooperação no formato convênio}

Em janeiro de 2001 surgiu, então, a primeira Norma Operacional de Assistência à Saúde (NOAS-SUS 01/01), cujo objetivo era “(...) promover maior eqüidade na alocação de recursos e no acesso da população às ações e serviços de saúde em todos os níveis de atenção” .

A intenção dos envolvidos na gestão do SUS era o desenho de um novo modelo de descentralização que incorporasse o processo de regionalização. Para isso, como já observado, basearam-se em três fatores: a elaboração do Plano Diretor de Regionalização que contemple as diretrizes para a organização regionalizada da prestação de serviços de saúde pública; o fortalecimento e a ampliação dos instrumentos de gestão das elites políticas estaduais e municipais, principalmente, aqueles voltados ao monitoramento; e, a atualização dos critérios e do processo de habilitação de Estados e Municípios, em coerência com a mudança institucional desenhada.

Vimos também, que esse novo modelo, além de ratificar as ações mínimas de atenção básica, propõe a formação de módulos assistenciais resolutivos, constituídos por um ou mais Municípios, que garantam, no âmbito regional, o acesso a todos consumidores-eleitores, em especial, àqueles residentes em Municípios "latentes". O objetivo que se revela com esse novo modelo é a solução dos problemas de externalidade, garantindo o acesso a um determinado padrão de serviços públicos para além dos limites jurisdicionais municipais, com relativa qualidade e economia de escala.

Esse modelo de regionalização e a estrutura de cooperação que resulta dele com características de uma formatação em convênios, é institucionalmente incentivado por meio da NOAS-SUS 01/01, pois requer a articulação das elites políticas municipais envolvidas sob a coordenação e a regulação estadual; e, o instrumento para a coordenação e a regulamentação adotado, dado o modelo de regionalização desenhado, é a Programação Pactuada e Integrada, o que nos remete, novamente às questões de financiamento. 
Sob esse ponto de vista, a NOAS-SUS 01/01, além de ratificar o critério "per capita”, também amplia os valores referentes ao Piso de Atenção Básica fixo por Estado e, além disso, o valor "per capita" referente às ações do primeiro nível da média complexidade ambulatorial passa a ser a ser a nível nacional. Isso representa uma ruptura com o modelo anterior onde o financiamento era orientado pela oferta instalada de serviços, que muitas vezes não correspondia ao esperado pelos consumidores-eleitores.

Decorreu dessa mudança institucional, segundo Brasil (2002b), uma intensa movimentação de vários Estados e respectivos Municípios para a regionalização dos serviços de saúde pública, de tal modo que, em outubro de 2001, 22 dos 27 Estados haviam elaborado pelo menos um esboço de Plano Diretor de Regionalização da Assistência, e encaminhado para uma primeira análise no Ministério da Saúde. Porém, também surgiram alguns problemas relacionados às insuficiências e distorções da NOAS-SUS 01/01.

\section{1. - dificuldades dos Estados com a NOAS-SUS}

De imediato, destacamos de Brasil (2002b), o seguinte trecho: “(...) as oscilações nos resultados eleitorais dos atores principais do SUS suscitaram mudanças na correlação de forças nos vários processos regionais de tomada de decisão sobre política pública de saúde, e levaram a uma intensificação das barganhas para acomodação dos vários custos atinentes às respectivas redes (estruturas) de cooperação regional” .

Em outras palavras, em alguns Estados a NOAS-SUS 01/01 encontrou alguns entraves na operacionalização de determinadas diretrizes, decorrentes das dificuldades em se estabelecer o comando único sobre os prestadores de serviços e, assegurar a totalidade da gestão municipal nas sedes dos "módulos assistenciais",230, bem como, o

\footnotetext{
${ }^{230}$ Tratam-se de estruturas de cooperação, que se configuram numa arquitetura contratual sob a forma de convênios.
} 
fato desta norma conter uma especificação frágil dos mecanismos necessários para que as burocracias estaduais atuassem com eficiência sobre as referências intermunicipais.

Portanto, a questão central se fixou em termos de como efetivar o comando único das estruturas de cooperação regionais, principalmente, sobre os prestadores de serviços de média e alta complexidade. Note-se que, em geral, esses prestadores situam-se em Municípios "monopsônicos" ou "privilegiados" e, portanto, muitas vezes referencia política dentro dos respectivos Estados, o que reforça a necessidade de se fortalecer a gestão dos Estados sobre os padrões de serviço de referência intermunicipal.

Essas questões de cunho eminentemente político, culminaram com a edição da Norma Operacional da Assistência à Saúde 01/2002 - NOAS-SUS 01/02, pela qual se introduziram algumas alterações nas regras que regem $\mathrm{o}$ processo de descentralização, das quais destacamos duas, como principais em relação à NOAS-SUS $01 / 01$.

Uma dessas mudanças institucionais é a que diz respeito ao comando único sobre os prestadores. Ou seja, mantida a idéia de comando único, admite-se a existência de módulos assistenciais em que o Município-sede possa estar habilitado apenas em GPAB-A (portanto, sem condições de habilitar em GPSM), só que, nessa situação, o comando único do sistema nesse Município-sede seria da burocracia estadual, o qual passa a receber diretamente no seu fundo estadual os recursos correspondentes aos serviços prestados por esse Município-sede, repassando-os em seguida.

A outra mudança a ser destacada é a que se refere à gestão das referências intermunicipais. Ou seja, a nova versão altera alguns dispositivos no sentido de fortalecer o papel do Estado na gestão das referências intermunicipais, incluindo a mudança na forma de apresentação dos tetos financeiros municipais.

Segundo Brasil (2002b), a NOAS SUS 01/02 resultou em um “(...) intenso movimento dos Estados - particularmente os que já haviam avançado no processo de negociação local e planejamento regionalizado da assistência - na conclusão dos seus Planos de Regionalização, Planos Diretores de Investimento e da Programação Pactuada e Integrada” . 
Ou seja, segundo a Secretaria de Assistência à Saúde do Ministério da Saúde, em agosto de 2002, alguns Estados já se encontravam plenamente habilitados ao sistema estadual, eram: Santa Catarina, Paraná, Mato Grosso do Sul, Mato Grosso, Goiás, Rio de Janeiro, Sergipe, Alagoas, Paraíba, Ceará e Pará. Apenas o Estado do Amapá não havia se apresentado à habilitação, enquanto os demais, estavam em fase avançada de habilitação.

\section{2. - dificuldades dos Municípios com a NOAS-SUS}

Brasil (2002b) observa que algumas das dificuldades encontradas pelos Municípios na NOB-01/96 foram também identificadas na implantação do novo modelo regrado pela NOAS-SUS 01/01. Em geral, essas dificuldades se referiam a problemas na avaliação do desempenho dos Municípios habilitados; afinal, os Municípios, até por estarem habilitados, deveriam ser monitorados e, no entanto, os Estados, a quem competiria essa função, não dispunham dos instrumentos institucionais necessários.

Em razão disso, ocorreram varias distorções em diversos Estados com o compartilhamento inadequado da gestão de política pública de saúde com os respectivos Municípios, que acabaram por repercutir em falhas nos processos de programação integrada, além das ineficiências de monitoramento. Brasil (2002b) também observa que as barganhas entre as elites políticas estaduais e as respectivas municipais ocorreram de forma distinta entre os Estados, uma vez que o ambiente em que se davam era influenciado pelo equilíbrio de forças políticas entre esses atores.

Daí o papel incentivador que a NOAS-SUS teve junto à burocracia estadual, na medida em que ampliava e ratificava o seu papel de coordenação das ações de saúde pública. Algumas dessas burocracias puderam coordenar processos de Programação Pactuada e Integrada mais consistentes, a partir de uma maior transparência com a definição de tetos financeiros por Município.

Por outro lado, a NOAS, enquanto incentivo à habilitação dos Municípios, teve uma atuação no mesmo período "incipiente", haja visto que, segundo a Secretaria 
de Assistência à Saúde do Ministério da Saúde, em agosto de 2002, apenas três Estados tinham Municípios habilitados em Gestão Plena do Sistema Municipal, sendo que: 5 em Alagoas, 23 no Ceará e 1 na Paraíba. E habilitados à Gestão Plena da Atenção Básica Ampliada em agosto de 2002, apenas 4 Municípios no Estado de Santa Catarina.

No entanto, essa constatação pode estar relacionada com as novas exigências e regras contidas na NOAS, que condicionam a habilitação dos Municípios a uma avaliação mais "severa e atenta" da burocracia estadual, diminuindo o peso relativo da tomada de decisão da respectiva burocracia municipal, principalmente, no que se refere à iniciativa em se enquadrar às novas modalidades impostas pela NOAS.

Tanto pode ser verdade que, de certa forma, a escolha da modalidade de gestão a que o Município poderia se enquadrar deixou de ser uma decisão exclusiva da respectiva elite política municipal ${ }^{231}$, na medida em que passou a depender, além de sua disposição à inserção na estrutura de serviços na região, também do excedente e da complexidade de sua capacidade prestação de serviços instalada que poderia ser colocada a disposição da demanda reprimida de Municípios vizinhos e, não apenas, de sua motivação ao influxo de transferencias financeiras.

Com isso, entendemos que a burocracia estadual, na elaboração do Plano Diretor de Regionalização, além de classificar os Municípios pelo seu potencial instalado como sede de uma região, deveria em suas respectivas barganhas políticas considerar em sua classificação critérios outros que envolvam distinguí-los pela necessidade e forma de monitoramento a semelhança da classificação que apresentamos no segundo capitulo, de "monopsônico" a "latente", o que nos remete às considerações sobre incentivos seletivos à habilitação dos Municípios.

Afinal, ainda não podemos dimensionar até que ponto as "vantagens" previstas na NOAS e as novas regras para a alocação das transferências financeiras poderão representar incentivos suficientes para que os Municípios busquem a habilitação prevista. De qualquer forma, ao longo deste trabalho evidenciou-se, principalmente com relação à aplicação deste novo modelo de regionalização do SUS,

\footnotetext{
${ }^{231}$ No entanto, há que se respeitar a Lei de Responsabilidade Fiscal (Lei Complementar $\mathrm{n}^{\circ}$ 101, de 2000) que obriga os Municípios a uma maior cautela na gestão do gasto público, o que permite supor a
} 
um papel mais ativo à União como indutora a essa habilitação municipal, a fim de se viabilizar a inserção dos chamados potencialmente Municípios-sede, provavelmente se comportando como "monopsônicos" ou "privilegiados", em uma estrutura de cooperação regional.

Evidentemente, tal postura também deverá exigir que a União passe a lidar, ao lado dos problemas gerados pela informação assimétrica, com outros relacionados à coordenação, envolvendo, principalmente, a viabilização dos incentivos e do monitoramento. Talvez até em razão disso é que a União tenha migrado para um modelo de regionalização, adotando algumas estratégias voltadas ao fortalecimento de seu monitoramento sobre os Estados e Municípios e, da gestão pública exercida por estes entes federativos.

Para tanto, destacamos de Brasil (2002b), o seguinte: “(...) a União empreendeu um diagnóstico preliminar sobre a situação da descentralização nas diversas unidades federadas, reestruturou sua própria gestão atribuindo a alguns de seus técnicos a condição de referência aos gestores dos demais entes federativos e, elaborou algumas diretrizes e instrumentos de fortalecimento da atuação dos gestores em processos chaves de gestão, como Programação Pactuada e Integrada (PPI), regulação da assistência, centralização do cadastro e dos procedimentos contratuais de prestadores, controle e avaliação, entre outros" .

\section{8. a participação da sociedade na política da saúde}

As mudanças institucionais ocorridas no SUS, como se pode depreender nas seções anteriores, marca-se pela ação regulamentadora do Ministério da Saúde, que submete as demais esferas de governo ao princípio da utilidade (quase um "conformese, e receba") por meio de mecanismos coercitivos, expressos em regras, leis, sanções e transferências financeiras.

ocorrência de uma maior morosidade de suas respectivas burocracias na assunção de novos encargos e no crescimento da oferta de serviços a partir das regras estabelecidas pela NOAS. 
Às elites políticas municipais atribui-se a obrigação constitucional de oferecer serviços de saúde à população, conforme a necessidade local e a universalidade do acesso, embora sob a coordenação do ente federativo União, o qual delega parcialmente aos Estados, em meio a outro princípio constitucional: o da descentralização administrativa.

Aos gestores municipais resta a cooperação entre si, não só pela otimização e viabilização de estruturas prestadoras de serviços de saúde, muitas vezes até impostas, mas também, pelos incentivos (positivos e negativos) embutidos nas diretrizes e parâmetros normatizadores das transferências de recursos financeiros, e no regramento do SUS estabelecido por toda uma legislação setorial, culminada com a indução à regionalização das ações do SUS na NOAS-SUS 01/01.

Note-se que as mudanças institucionais ocorridas no SUS deram-se em paralelo com a formatação, quase que espontânea, de diversas estruturas de cooperação a partir de coalizões intermunicipais como os Consórcios Intermunicipais de Saúde. Afinal, vimos no capítulo anterior que este tipo de estrutura de cooperação, em geral, se caracteriza como uma personalidade de direito privado, com previsão legal no artigo 10, da Lei 8.080/90 que ratifica as possibilidade do desenvolvimento conjunto das ações e serviços de saúde pública. Além disso, se aplica o princípio constitucional da direção única, também contido no $\S 1^{\circ}$, do artigo 10, da Lei 8.080/90, que reserva aos Municípios envolvidos, por meio até da constituição de uma coalizão, a forma de melhor dispor deste princípio.

A Lei reserva às Direções Municipais do SUS (inciso VII, art. 18, Lei 8.080/90) a competência de formar os Consórcios Administrativos Intermunicipais, os quais poderão financiar a execução de suas ações e serviços com o remanejamento entre os Municípios envolvidos das respectivas parcelas de recursos com origem no Fundo Nacional de Saúde (FNS) ( $§ 3^{\circ}$, art. $3^{\circ}$, Lei 8.142/90) alocado com o propósito de atender às ações e serviços de saúde, quando implementados por eles próprios.

É interessante se observar que, independente da estrutura de cooperação intermunicipal ser induzida ou espontânea, os autores desenvolvimentistas afirmam que "uma das chaves do desenvolvimento local reside na capacidade de cooperação entre os atores" (Godard et al., 1987) e, portanto, colocando em primeiro plano a forma com 
que ela é obtida, uma vez que, desconhecer os incentivos seria como negar a possibilidade de se maximizar a “(...) capacidade de cooperação (...)” .

Um dos conceitos mais recentes que se aplica nesse campo é o de capital social e, em especial, a sua influência no desenvolvimento econômico de uma região. Não é nossa intenção ampliar a discussão nesse tema, mas apenas de trazer o seu conceito como a resultante envoltória de um conjunto de características de uma organização social, como o SUS, tais como: redes de relações, normas comportamentais, valores, confiança, obrigações e canais de informação. Afinal, é esse conjunto que torna possível a tomada de ações cooperativas que resultam no benefício de toda uma comunidade.

Ou seja, num sentido mais restrito, podemos adotar a definição que Portes e Landolt (1996) dão ao capital social: "a habilidade de criar e sustentar associações voluntárias”, principalmente, segundo Amaral Filho, (1996), se essas associações visam proporcionar um desenvolvimento local como se fosse um “(...) processo interno de ampliação contínua da capacidade de agregação de valor sobre a produção, bem como da capacidade de absorção da região, cujo desdobramento é a retenção do excedente econômico gerado na economia local (...)” , , tendo “(...) como resultado a ampliação do emprego, do produto, e da renda local ou da região” .

Note-se que nessa postura há uma dimensão econômica de desenvolvimento regional endógeno, possível de se encontrar em uma sociedade local que utilize a sua capacidade de ação coletiva para organizar formas eficientes de aproveitamento de seus fatores de produção. Por outro lado, também podemos identificar uma dimensão sóciocultural, onde os valores e as instituições locais e exógenos estariam servindo de base para o desenvolvimento da região.

Assim sendo, se referenciarmos esse desenvolvimento ao âmbito das políticas públicas de saúde, em especial, ao SUS, de tal forma que esse desenvolvimento se manifeste com o atendimento de um dado Município às condições impostas pelas normas do SUS voltadas a sua habilitação em Gestão Plena do Sistema Municipal GPSM, então, nesse sentido e, a partir da presunção de que a tomada de decisão nesse sentido se relaciona com a postura coletiva assumida pela maioria do respectivo grupo de consumidores-eleitores, poderíamos identificar na respectiva elite municipal a 
disposição política a desenvolver também na esfera regional, as condições endógenas necessárias ao atendimento da normatização das ações de saúde públicas.

Observe-se que tal presunção se adere ao preceito constitucional da participação da comunidade na gestão do SUS (inciso III, art. 198, CF 88) e, além disso, ratifica a promoção, a participação e a abertura ao diálogo com os diversos entes integrantes da federação brasileira, em especial os Municípios, como uma das formas do Ministério da Saúde atuar de modo eficiente, ao lado das constantes mudanças institucionais e incrementais empreendidas pelo SUS.

Ou seja, a real participação da comunidade nos processos de composição e implantação de iniciativas públicas exige uma certa dose de capacidade política das elites políticas e da própria sociedade, devendo as várias burocracias envolvidas nos programas de saúde pública estarem preparadas a conviver com os conflitos advindos dessa participação, visto que as relações de poder entre elas e a sociedade passam a ter que se caracterizar pela transparência, o que, de certa forma amplia o controle do último sobre os primeiros.

É uma situação na qual, segundo Ostrom (1996), se a operacionalização dessas relações, envolvendo as ações das elites políticas, das burocracias e da sociedade civil puderem se complementar, então, se abre caminho para a realização de composições harmônicas entre os atores envolvidos.

Contudo, pode-se também gerar um “(...) potencial para sinergia mas não as bases organizacionais para realizar o potencial” (Evans, 1996). Afinal, o ponto fraco pode estar na capacidade da sociedade civil se organizar e, se a sociedade não dispõe dessas bases, então caberia ao Ministério da Saúde atuar com medidas voltadas à promoção do desenvolvimento e da melhoria da qualidade de vida, regrando tal complementariedade através de toda uma legislação infraconstitucional aplicada ao setor saúde.

Essas regras, que em última instância vão compor as estratégias locais de cooperação, devem estar preparadas a algumas formas alternativas de políticas de gestão local, por exemplo, a formatação estruturas de cooperação tais como as coalizões em consórcios intermunicipais, ou mesmo, aquelas baseadas em convênios intermunicipais firmados sob a coordenação dos respectivos Estados, onde o sucesso da 
cooperação está condicionado às várias características que compõem as relações entre os agentes envolvidos.

Entre as possibilidades de atuação do Ministério da Saúde, e mesmo das Secretarias Estaduais de Saúde, na "alavancagem" da cooperação entre os Municípios está a disseminação da idéia de eficiência coletiva através da sugestão de uma política de fomento ao compartilhamento de ações de saúde, implícita nas diversas NOB's, e mais recentemente, na NOAS-SUS 01/01, além da postura assumida de regulamentador, orientador e de mediador dos conflitos que possam existir, e que estejam "fora de alcance" dos mecanismos institucionais criados no âmbito municipal, para a consolidação dos laços comuns.

Talvez por essa lógica, é que a lei contempla o SUS, em cada esfera de governo (art. $1^{\circ}$, Lei 8.142/90), com duas instâncias colegiadas: a Conferência de Saúde e o Conselho de Saúde; sendo competência do primeiro o ditar das diretrizes da política de saúde em reuniões ordinárias a cada quatro anos, ou extraordinárias, convocadas pelo respectivo Poder Executivo ou pelo Conselho de Saúde.

Quanto ao Conselho de Saúde, órgão deliberativo, permanente e representativo da sociedade e governo, atribui-se a competência legal para atuar na formulação de estratégias e no controle da execução da política de saúde correspondente a sua instância federativa, inclusive sobre aspectos econômicos e financeiros. Desta forma, o Conselho de Saúde é “composto por representantes do Governo, de profissionais de saúde, de prestadores de serviços de saúde e usuários, sendo o seu presidente eleito entre os seus membros, em reunião plenária” $\quad$ (Res. n. ${ }^{\circ}$ $33 / 92$ ), de tal sorte que o número de seus membros varie entre 10 e 20 , sendo que $50 \%$ de usuários, $25 \%$ de trabalhadores de saúde e $25 \%$ de prestadores de serviços públicos e/ou privados.

Se de âmbito municipal, os seus atos serão homologados pelo chefe do Poder Executivo local, ou por delegação ao respectivo Secretário da Saúde, e poderão atuar desde a formulação e controle da execução de qualquer política de saúde, passando pelo estabelecimento de estratégias e mecanismos de coordenação e gestão do SUS, articulando-se, se necessário, com os demais colegiados, até na fiscalização da movimentação dos recursos repassados. 
Entre as competências atribuídas aos Conselhos de Saúde por meio da Resolução n. 33 do Ministro da Saúde, também estão presentes a de "estabelecer estratégias e mecanismos de coordenação e gestão do SUS, articulando-se com os demais colegiados em nível nacional, estadual ou municipal " e a de "estabelecer critérios e diretrizes quanto à localização e ao tipo de unidades prestadoras de serviços de saúde públicos e privados, no âmbito do SUS” .

Estas atribuições representam esforços normatizadores excedentes do Ministério da Saúde que podem ser utilizados para confirmar as estruturas de cooperação intermunicipal como associações entre Municípios que visam a realização de atividades conjuntas de promoção, proteção e recuperação da saúde dos respectivos grupos jurisdicionais de consumidores-eleitores, reforçando o processo de descentralização e o exercício da gestão conferida constitucionalmente aos Municípios no âmbito do Sistema Único de Saúde - SUS. 


\section{CONSIDERAÇÕES FINAIS}

Praticamente concluímos o trabalho e estamos no momento de apresentar uma resposta à questão inicial: como se dá a cooperação intermunicipal no âmbito da saúde pública, em especial, no âmbito do SUS? Porém, não há como estabelecer uma digressão lógica que coloque em uma única envoltória todas as variáveis explicativas aqui abordadas.

Afinal, a cooperação intermunicipal não possui um formato único, pois a sua estruturação pode variar de plenamente espontânea a totalmente induzida, de tal forma que uma espontânea nunca prescinde de incentivos, ao mesmo tempo em que a induzida sempre necessitará da anuência, ainda que tácita, dos Municípios envolvidos.

Além disso, estruturas de cooperação também podem se diferenciar entre si pelas motivações e condições observadas em sua constituição e, pelo ambiente políticoeconômico-institucional no qual se inserem.

De qualquer forma, a partir de conceitos como externalidade, motivação e coordenação, entre outros, procuramos abordar a questão de como se processam as tomadas de decisão de se estruturar, ou não, a cooperação e, tendo em vista a não existência de literatura aplicada específica ao tema, acabamos lidando com um campo teórico bastante amplo, subdividido em quatro capítulos.

Nossa discussão procurou cobrir o setor público da saúde, onde há externalidades envolvendo todos os tipos de entes federativos, podendo essas externalidades serem horizontais ou verticais, com implicações na política redistributiva das respectivas elites políticas, dependendo delas serem doadoras ou receptoras líquidas de transferências financeiras.

Com isso, queremos dizer que admitida a existência de uma estrutura fiscal, nos concentramos nas suas implicações e, não, no porquê de ela existir. Assim sendo, ao lidarmos com o federalismo fiscal brasileiro, verificamos que, ao lado das externalidades horizontais há que se observar as externalidades verticais, na medida em que o seu entendimento implica na compreensão da relação entre o SUS e os Municípios. Tanto é verdade, que as normatizações do SUS e os critérios para as 
transferências financeiras podem implicar em "ajustes exógenos" no Orçamento Público dos Municípios e, assim sendo, também podem influenciar na adoção das respectivas políticas públicas de saúde.

De qualquer forma, regulamentar as políticas públicas em um sistema federativo tem conseqüências redistributivas que se realizam pela interação dos entes federativos. Isso significa que, ainda que o SUS aja como um planejador central, deve levar em consideração que as elites políticas estaduais e municipais poderão reaplicar os recursos distribuídos, uma vez que o sistema é o federativo e, não o unitário, como seria de esperar daquele no qual se insere um planejador central.

O que se conclui é que, embora o SUS se comporte como um planejador centralizado, as interações do sistema federativo conduzem a um equilíbrio melhor, ainda que não necessariamente o ótimo projetado. Dessa forma, pode-se esperar que o equilíbrio encontrado seja múltiplo, um por região, dadas as posturas ideológicas assumidas pelos respectivos grupos jurisdicionais de residentes para a alocação possível dos recursos.

Um paradoxo interessante encontrado na interação dos Municípios é que nem sempre a competição tributária, ou a chamada "guerra fiscal", é um elemento desmotivador à cooperação intermunicipal, como inicialmente se fazia presumir. Afinal, a primeira idéia que surge é que ela é nociva, na medida em que conduz à prática de alíquotas tributárias ineficientemente baixas e, portanto, a ineficientes ofertas de serviços públicos. Porém, há circunstâncias em que a competição tributária tem aspectos benéficos, se considerarmos que a mobilidade de consumidores-eleitores e fatores pode induzir as elites políticas municipais à reduzir os desperdícios de recursos.

É só nos lembrarmos do mundo de Tiebout, em que os agentes revelam suas preferências escolhendo o Município pelo padrão ofertado de serviço público como se estivessem em um "shopping center", e, dessa forma, a competição na oferta do melhor padrão conduziria à eficiência e realçaria os incentivos à mobilidade de consumidoreseleitores e de fatores.

Note-se que, no exemplo proposto por Tiebout, se demonstra que a competição intermunicipal tem bons e maus aspectos, variando com os atributos que se espera dos serviços públicos de saúde providos aos consumidores-eleitores pelos 
Municípios. Para isso, devemos reconhecer que estes incentivos desenhados no exemplo por Tiebout operam em um ambiente com falhas de mercado e, portanto, o equilíbrio eficiente, embora possível, seria novamente pouco provável.

O que, de certa forma, explica o mundo real, na medida em que, até no exemplo do "shopping center" de Tiebout submetido às falhas de mercado também abre espaço para a intervenção de um regulamentador dessa oferta, que no presente caso poderia ser desempenhado pelo SUS.

Por outro lado, ao se presumir a necessidade de um ente regulamentador, presumimos outros problemas, só que desta feita advindos da necessidade de esse ente exercer a atividade de coordenação e de se manter informado sobre as preferências dos indivíduos, na medida em que, muito provavelmente, os Municípios tenham que ser induzidos à cooperação com incentivos em algum grau seletivos, principalmente, aqueles em "guerra fiscal", ou do tipo "monopsônicos", por exemplo.

No entanto, observe-se que essas novas atribuições não diminuem a responsabilidade desse ente supra-municipal de exercer as funções redistributiva e, principalmente, alocativa dos recursos voltados à prestação de serviços públicos de saúde, tal qual o mundo teórico de Musgrave.

De qualquer forma, no capítulo inicial e, a partir de Musgrave e Tiebout, procuramos explicar a formatação de estruturas de cooperação intermunicipais sob a ótica da teoria econômica tradicional. Porém, pudemos constatar sua limitação em razão de essa teoria se pautar na escolha individual, porquanto a tomada de decisão atinente à política pública de saúde passa por um processo de escolha em ambiente político, sujeito a regras democráticas, onde as decisões individuais são consideradas coletivamente.

No entanto, essa limitação não diminui a constatação de que, quanto maior a mobilidade dos indivíduos, maior tende a ser a confiabilidade da sinalização recebida pelas elites políticas municipais sobre as preferências de seus respectivos residentes por determinados padrões de saúde pública e, portanto, essas elites poderiam ajustar seus gastos ao padrão desejado pela maioria de seus residentes. Além disso, essas elites, diante da preferência revelada pela maioria de seus residentes, poderia, inclusive, 
ajustar suas políticas de alíquotas tributárias aos padrões de gastos e de transferências verticais instituídos pelo SUS, minimizando seus problemas de externalidade.

Conhecidas as preferências da maioria dos indivíduos, caberia às elites políticas otimizar os recursos disponíveis para a melhor solução possível, a qual, aplicada aos serviços prestados de saúde pública por Municípios, tenderia a eficiência na medida em que se considere a regionalização de sua oferta.

Foi dessa forma que, no desenvolvimento deste trabalho, atrelada ao fato da teoria tradicional de que finanças públicas tem um de seus fundamentos no conceito de escolha individual, justificou-se a adoção da teoria da escolha coletiva. No entanto, tivemos a precaução de manter o enfoque da política de alíquotas tributárias, a fim de propiciar uma correlação teórica entre gastos públicos e política de redistribuição com a teoria da escolha coletiva.

Nesse ambiente de decisão, notoriamente político, foram inseridos vários outros personagens. Entre eles, os partidos políticos que buscam ampliar suas bases eleitorais e as elites políticas, cuja racionalidade, embora limitada, foi considerada suficiente para a perceber o custo político (de transação) a incorrer numa tomada de decisão.

Portanto, dada a racionalidade econômica das elites políticas, já na decisão delas de participar, ou não, de uma barganha pela constituição de uma estrutura de cooperação, tendem a considerar quanto das transferências líquidas de recursos a essa futura estrutura influenciaria a condução de outras políticas públicas. Além disso, é até óbvio que, na medida em que o custo político desse processo de barganha seja maior que os benefícios esperados, a tendência é a preservação do "status quo".

Foi interessante abordarmos o custo político, pois, a hipótese de que quanto mais a estrutura formatada de cooperação tender a espontânea, maior é a sua influência na tomada de decisão das elites políticas, pôde ser constatada pelo inverso na abordagem das mudanças institucionais ocorridas no SUS. Ou seja, vimos que a indução à cooperação, construída a partir de sucessivas normas instituídas pelo SUS, passa ter maior efeito sobre a tomada de decisão das elites políticas municipais com a edição do modelo de regionalização dos serviços de saúde pública e, dessa forma, minimizaram-se os efeitos dos custos políticos na tomada de decisão, uma vez que há a 
redução dos atritos advindos da barganha entre as elites políticas municipais em estruturar a cooperação intermunicipal, com a maior responsabilidade atribuída à União.

O conceito de custo político também contribuiu para a compreensão dos efeitos da política de alíquotas tributária na tomada de decisão pró ou contra a estruturação da cooperação, principalmente se espontânea, com a ressalva de que o contraponto dado à política pública de saúde pela de alíquotas tributárias visou consubstanciar e incorporar, a este trabalho, as motivações do "homem econômico" em financiar ações de políticas públicas em geral.

Observa-se que, além de procurarmos identificar as motivações das elites políticas, também buscamos desenhar, em capítulo próprio, a arquitetura contratual desejável de uma estrutura de cooperação, independente de ser espontânea ou induzida. No entanto, ressalte-se que a estrutura induzida tende a ter suas características institucionalizadas "ex-ante", tanto as que se referem ao padrão de serviços a ofertar quanto à forma de financiamento de suas ações, a fim de se viabilizar a coordenação de sua implantação e, então, “ex-post”, facilitar o monitoramento dessas estruturas.

Assim sendo, o sistema de alíquotas tributárias surge para o entendimento de como se dá a tomada de decisão de um elite política municipal, principalmente quanto à forma, pois, nos parece lógico que, a partir da escolha pública e da forma com que um determinado sistema de alíquotas tributárias é projetado, se possam entender as motivações das elites políticas municipais quanto aos gastos fiscais em geral e, conseqüentemente, quanto à participação dos Municípios com recursos próprios na formatação de uma estrutura de cooperação, seja ela espontânea ou induzida.

Como exemplo, basta apenas observarmos a promulgação da Emenda Constitucional 29 aplicada à política pública de saúde, que estabelece percentuais mínimos de participação de sua receita própria voltadas à política pública de saúde. Fica a dúvida de como as elites municipais conduzirão suas respectivas políticas de alíquotas tributárias, tendo em vista a complementariedade de outras políticas públicas com as pressões desses grupos pela preservação do respectivo volume de receita. Provavelmente, trará consequiências de externalidade e, portanto, à estabilidade das estruturas de cooperação. 
Portanto, o ambiente onde as decisões sobre políticas públicas são tomadas é eminentemente político. E, se as barganhas de políticas públicas são definidas em arenas políticas, ainda que motivadas economicamente, então, ao recorrermos à teoria da escolha pública, devemos estar atentos à regra de tomada de decisão, que, em geral é a de maioria simples.

No entanto, a regra democrática tem limitações quanto à sua aplicação em razão do formato que se pretende à estrutura da cooperação. Afinal, numa estrutura de convênio, induzida pelo SUS, dificilmente sob a ótica institucionalista, conseguiremos enxergar o SUS como uma instituição suficientemente "democrática" a ponto de se propor negociar previamente com os entes municipais a solução ótima para cada caso.

Até porque, na nossa percepção, as Câmaras Intergestoras, enquanto canais de representação política, além de revelarem algumas preferências dos demais entes federativos, suprindo deficiências informacionais dos Estados e União, teria como principal objetivo a certificação das responsabilidades de prestação dos serviços de saúde pública, as quais são distribuídas a partir de normas instituídas pelo SUS.

Porém, ainda que induzida pelo SUS, a adesão a uma estrutura de cooperação do tipo convênio passa pela anuência das respectivas elites políticas municipais, as quais tendem a tomar decisões coladas às preferências da maioria de seu respectivo grupo jurisdicional de consumidores-eleitores. E, como vimos que os grupos de consumidores-eleitores tem comportamentos coletivos que caracterizam seus respectivos Municípios de "monopsônico" a "latente" e, portanto, a depender do tipo de estrutura de cooperação proposta, a tomada de decisão coletiva pode não ser suficientemente eficiente, demandando maiores esforços de coordenação com a proposição de incentivos seletivos.

Neste ponto, é interessante fazermos algumas correlações entre o mundo real, com o mundo teórico objeto deste trabalho. Observe-se que são os Municípios com os principais centros de referência que se aproximam da tipificação de "preferênciais" a “monopsônicos" e, portanto, são os que exigem maiores esforços de coordenação e que tendem a não participar de estruturas espontâneas. A eles o SUS atua com incentivos seletivos conferidos por meio da PPI e do PDR, no interesse da equalização e do acesso 
universal aos serviços de saúde pública, a fim de induzi-los a se envolverem em estruturas de cooperação do tipo convênio como "exportadores líquidos" de serviços.

Enquanto que são os Municípios “intermediários” e, principalmente, os "latentes" que demandam menos esforço de coordenação e que tendem naturalmente a estruturarem a cooperação intermunicipal espontânea. Talvez por isso mesmo, são esses Municípios que mais "facilmente" são induzidos a uma estrutura do tipo convênio, na medida em que forem os "importadores líquidos" de serviço na região.

Note-se que, nas "entrelinhas" desta última conclusão, estão conceitos como externalidade e motivação. Em especial, com a constituição de uma estrutura de cooperação, internam-se as externalidades ao se regulamentarem formas de compensação financeira entre importadores e exportadores. E, além disso, o compartilhamento de recursos ociosos e o acesso às ações de maior complexidade em Municípios de referência vizinhos atuam como motivação suplementar à normatização instituída pelo SUS.

Um tema que surgiu neste trabalho foi a forma com que as interações ocorrem e são administradas, sejam elas as intramunicipais, as intermunicipais, ou mesmo, as que envolvem a União, por meio do SUS, com os Municípios. Tanto a sua variedade quanto a sua importância denotam a necessidade de se fixarem regras de conduta claras, para que haja a acomodação de interesses e se assegure que os melhores resultados possíveis sejam alcançados por todos os envolvidos.

No estudo da estrutura de governança, principalmente de uma cooperação intermunicipal espontânea, partimos de um caso aplicado a um sistema social de produção formatado como uma rede de "franchising" voltada à oferta de produtos de consumo obtidos a partir da moagem do trigo. Portanto, a adaptação pode recair sobre a agregação espontânea de entes federativos municipais, contanto que tivessem algumas similaridades: tamanho, distribuição populacional, nível de desenvolvimento econômico, proximidade geográfica, ideologias e, que além disso, tomassem decisões sob as mesmas regras.

O interessante é que, por mais que se aproxime do pólo plenamente espontâneo, a estruturação de uma cooperação intermunicipal não prescinde de uma política pública comum e nem da posição de receptor líquido de recursos financeiros, o 
que abre espaço, em ambos os casos, à regulamentação da União, na figura do SUS. Afinal, por mais sofisticada e espontânea que possa ser a estrutura de governança formatada pelas elites políticas municipais, para que se assegure a cooperação entre elas, há a necessidade de incentivos que compensem as perdas de autonomia administrativa e regras claras voltadas à distribuição dos bônus políticos entre elas.

O bom senso afirma que a racionalidade econômica e os fundamentos políticos devem nortear um contrato público que constitua uma estrutura de cooperação intermunicipal. Porém, é inevitável o processo de barganha, gerador de conflitos entre as elites políticas envolvidas e, entre estas e a burocracia da cooperação. Portanto, dado que a natureza dessa estrutura de cooperação é obtida de barganhas políticas, a definição das regras a serem previstas em seu contrato constitutivo assume um papel significativo.

Além disso, há que se tomar o devido cuidado em se preverem quais regras e em quais circunstâncias, seriam passíveis de alteração, a fim de se ampliar a credibilidade dessas regras e de se reduzirem custos de políticos futuros.

É evidente que um dos objetivos das elites políticas municipais em participar de uma estrutura de cooperação é a viabilização de ações continuadas e em comum de saúde pública, determinando padrões regionais colados à própria realidade política e social. Se isso é verdade, então, seria possível admitir-se que, no limite, cada elite política venha a adotar políticas de alíquotas tributárias mais desvinculadas dos recursos obtidos de transferências da União, ao mesmo tempo em que essas políticas de alíquotas se tornem cada vez mais uniformes na região.

Caso essa tendência se constate e, considerando que as regras de tomada de decisão coletiva são democráticas, então, poderíamos inferir a eficiência econômica da prestação de serviços públicos de saúde na região a partir de uma estrutura de governança regional voltada a essa prestação, estrutura essa que, além de propiciar uma estabilidade na divisão das responsabilidades, dos bônus políticos e das transferências horizontais de recursos entre os Municípios, também induzisse suas respectivas elites políticas a um comportamento tributário mais "responsável" e, assim ocorrendo, pudesse legitimar a burocracia dessa estrutura para o exercício de ações de coordenação horizontal que lhes fossem confiadas pelas mesmas elites políticas. 
Portanto, os arranjos para a viabilização financeira da estrutura de cooperação, seja a induzida ou mesmo a espontânea, se constituem em um componente importante, pois, mudanças neste tema se refletem em mudanças na própria cooperação. Afinal, embora qualquer estrutura de cooperação seja uma criação política com fins próprios, também tem fins eleitorais e, assim sendo, a sua estrutura de governança deve ser analisada dentro de uma postura político-ideológica. E, além disso, essa postura está presente na "gênese" da estruturação da cooperação, ou seja, na definição ideológica de se estruturar ou não a cooperação na região, o que, evidentemente, acaba por repercutir no seu desenho contratual.

Já a posição ideológica das maiorias dos grupos de consumidores-eleitores envolvidos na estruturação de uma cooperação também influi no regramento das decisões referentes às ações de uma estrutura de governança e, no processo de como essas regras são mudadas. Portanto, além de se buscar viabilizar financeiramente a estrutura de cooperação, também se deveria conferir suficiente transparência ao fluxo informação utilizado no processo de tomada de decisão, tanto das elites políticas quanto de sua burocracia e, assim sendo, possibilitar que o exercício do monitoramento pelos representantes dos consumidores-eleitores afete também o resultado obtido, garantindoo próximo ao esperado. Vimos que a voz dos consumidores-eleitores pode ser representada pelo Conselho Municipal de Saúde.

De qualquer forma, dentro do contexto de que há sempre um processo de barganha política, seja qual for o formato da estrutura de governança, esta deverá estar apta a receber, acomodar e, se possível, incorporar a análise ideológica ao processo de tomada de decisão de sua burocracia.

Uma primeira conclusão surge das assimetrias de informações entre governos e, portanto, do quão benéfica poderia ser a intervenção do SUS. Afinal, em seu início, tal qual um ente centralizador e benevolente de conduta "indutora" das ações dos Municípios, o SUS se compromete normatizando a política pública de saúde, fazendo uso das transferências para não só induzir, mas também reproduzir um padrão ótimo em todos os Municípios indistintamente, sinalizando, desta forma, que considera trivial qualquer interação entre eles. 
Porém, à medida que se evidenciam outras variáveis, esse comportamento fica ainda mais complexo. Ou seja, quando se fala no papel corretivo das transferências, nos seus aspectos distributivos e alocativos, implicitamente se assume que há diferenças entre os Municípios a serem consideradas, que "turvam” o SUS na busca desse ótimo. É como se o SUS se descobrisse sem os instrumentos necessários para reproduzir o ótimo, passando então apenas a induzir resultados esperados dos Municípios, na medida que reconhece neles diferentes capacidades de ação, que se complementam regionalmente.

Se há algo que se deve ter cuidado é a confusão entre a atitude benevolente de um governo e a necessária proteção de um governo forte. Enquanto a atitude benevolente implica em plena informação para a eficiência, a força requerida deve implicar na sua suficiência, tanto para coletar tributos dos consumidores-eleitores, quanto para protegê-los com a regulamentação de políticas públicas, reduzindo a influência dos chamados grupos de interesse. Essa talvez tenha sido uma das conseqüências das mudanças institucionais identificáveis no SUS.

Por outro lado, ao mesmo tempo em que se atribui ao SUS a exclusividade do exercício da regulamentação, também se amplia a sua dependência aos grupos de interesses, dada a assimetria de informações, tendo como consequiência, a ampliação do risco das externalidades intermunicipais. E, em assim sendo, o SUS, ainda que uma organização governamental no exercício de sua "força", passa a induzir padrões de atendimento diferentes por região, rompendo com o conceito da universalização do padrão da saúde pública por Município.

Observe que essa solução também seria ineficiente se o SUS se mantivesse centralizando os fundos do sistema, na medida em que esta situação também era um incentivo à formação de grupos de interesse. No entanto, este risco foi minimizado com a promulgação da Emenda Constitucional n 29, embora, numa primeira análise, com a União mantendo o sistema de transferências financeiras verticais, acreditamos que as elites políticas municipais continuarão a prática de sistemas "frouxos" de alíquotas tributárias, comportando-se oportunisticamente como "caronistas" no sistema como um todo, até porque persistem os efeitos das complementaridades das outras 
políticas públicas existentes e, portanto, a pressão dos vários grupos de interesse intramunicipais.

Por outro lado, quanto mais o financiamento do gasto em saúde pública for distribuído e regionalizado entre os Municípios, mais as suas elites políticas dependerão de suas receitas próprias para financiar políticas públicas, reduzindo a capacidade coercitiva das normatizações do SUS, ao mesmo tempo em que amplia a eficiência dos diversos sistemas municipais, na medida em que os respectivos padrões de serviço público de saúde mais se aproximam das necessidades de seus consumidores-eleitores.

Portanto, não seria sem motivo que a burocracia do SUS flexibilizasse a aplicação de seu padrão normatizado, em razão das possibilidades de cada Município de uma dada região, prevendo a possibilidade de que aquelas ações, antes atribuídas apenas a um sistema autônomo municipal, se desenvolvam sistemas intermunicipais.

O fato é que o SUS tem se empenhado em normatizar ações de saúde pública com a intenção da eqüidade intermunicipal, reconhecendo, desta forma, a existência de diferenças entre os Municípios. Afinal, esse processo de aprendizado é percebido na burocracia do SUS através das constantes mudanças institucionais, que culminaram com a NOAS-SUS 01/01, na qual, reconhece na regionalização a possibilidade de vários Municípios suprirem suas faltas de recursos em outros geograficamente próximos e, portanto, indiretamente, reconhecendo-se limitadamente informado.

De qualquer forma, seja a estrutura de cooperação formatada como coalizão ou convênio, evidencia-se a questão sobre a decisão da respectiva elite política estar ou não colada à escolha coletiva do correspondente grupo de consumidores-eleitores.

Aparentemente, essa questão tem solução a partir de dados extraídos de um sistema eleitoral e, em razão disso, desenhamos um mecanismo bipolar simplificado, sem preocupações com modelos de três ou mais partidos, ou mesmo, sistemas eleitorais de multe estágios. Afinal, nesse contexto eleitoral, a "palavra de ordem" é negociação, a qual incorpora o significado de acomodação de posturas ideológicas dos representantes dos vários grupos de consumidores-eleitores e das elites políticas, envolvidos nesse processo de tomada de decisão.

Por isso, quando polarizamos a escolha ideologia, criamos um mecanismo revelador das preferências dos grupos de consumidores-eleitores em aderir ou não a 
uma determinada forma estrutural de cooperação. Por esse mecanismo, os dois partidos políticos negociam com os grupos, procurando por sinais que indiquem se suas preferências são fortes ou fracas ideologicamente, para então, por meio de promessas de campanha, induzi-los a um posicionamento aferido como uma combinação linear entre os pólos pró e contra a cooperação.

Independente do que os consumidores-eleitores tenham a revelar num processo eleitoral, o fato é que eles têm percepções político-econômicas que afetam suas posturas ideológicas, na proporção em que estas são mais fracas. Entre elas, há as de cunho distributivo, tais como suas necessidades, os padrões de serviços ofertados, sua mobilidade e, até mesmo, a percepção que fazem do nível de centralização ou descentralização das tomadas de decisão. O ambiente político econômico também lhes sinaliza algumas noções sobre crescimento econômico e estabilidade, extraídos até mesmo da visão que cada um tem da "guerra fiscal" entre os Municípios.

Se admitirmos que todas essas percepções dos consumidores-eleitores se potencializam com o aprendizado em sucessivos processos eleitorais e, se enveredássemos pela teoria da ação coletiva, então, não só manteríamos o conceito da racionalidade econômica, como também poderíamos incorporar a noção de custos políticos $^{232}$ e, em assim fazendo, poderíamos esperar desenhar uma regra de comportamento para as elites políticas envolvidas na decisão de formar uma estrutura de cooperação.

Ora, a formação de uma estrutura de cooperação intermunicipal, como algo que emerge espontaneamente de um ciclo dinâmico, foi possível ser configurada a partir da autodeterminação ideológica de algumas elites políticas, sujeitas a identificarem entre si algumas intenções comuns, que se expressam numa avaliação dos recursos próprios e da possível otimização deles, se compartilhados. Afinal, a cooperação intermunicipal envolve complexas relações entre entes federativos, em geral, geograficamente próximos, cujas elites políticas se vêem na necessidade de coordenar esforços comuns e de desenvolver instituições especializadas e supramunicipais.

${ }^{232}$ A partir mesmo do conceito de custos de transação de Williamson. 
De certa forma, no momento da formatação dessa estrutura, as elites políticas estão procurando tornar o setor público de saúde mais reativo às variações de demanda dos consumidores-eleitores, principalmente, na medida em que estes adquiram maior consciência das funções das elites políticas de alocar e de distribuir recursos.

Além disso, se partirmos do princípio de que uma estrutura de cooperação espontânea é gestada endogenamente, caso contrário seria induzida, então, poderíamos até reinterpretar a mão invisível de Adam Smith agindo sobre a formação dessa estrutura, sobre o desenvolvimento dos serviços públicos e sobre a estabilidade político-financeira dessa estrutura na região.

A espontaneidade não significa a formação de estruturas exclusivas e, nem tão pouco, significa que devam ser idênticas. Até por que, qualquer estrutura reflete comportamentos racionais de otimização das elites políticas envolvidas, sem falar que no Brasil há estruturas de cooperação em coalizão voltadas para diversos fins, desde exames clínicos e ambulatoriais até exames laboratoriais. Ou seja, tais estruturas têm sua própria existência, com configurações funcionais diferenciadas e complementares ao restante do sistema de saúde pública instalado e, por isso mesmo, contém aspectos estruturais que mantém todos os Municípios aderidos. Inclusive, as regras de acesso, a distribuição orçamentária, os regulamentos baseados em critérios de otimização, entre outros.

$\mathrm{Na}$ verdade, o que transparece entre os dois formatos de estrutura de cooperação abordados, coalizão e convênio, é a própria concepção de formação de estruturas federativas. Enquanto a coalizão se assemelharia ao federalismo formatado de "baixo para cima", onde as partes constituem o todo, a de tipo convênio se assemelharia à formação de uma federação "de cima para baixo", com o todo definindo sua subdivisão.

Esse conceito federativo aplicado à estrutura de cooperação nos ratifica que há uma variação intensidade dos vínculos entre os envolvidos na medida em que também o tipo de estrutura formatada varie de uma coalizão à do tipo convênio. São esses vínculos assim criados, que dão a tendência com que a distribuição da tomada de decisão entre os entes federativos e a "legitimidade" da regulamentação das ações de uma dada política pública serão processadas. 
É por isso que o debate político centralização "versus" descentralização, do qual, inclusive, resultou a organização do SUS, também teve importância no transcurso deste trabalho. Esse debate ao longo do tempo, teve uma evolução pendular, afinal, se tomarmos seu início como sendo nos anos 60-80, caracterizaríamos a situação então vigente como sendo centralismo fiscal. Esse debate avança para um período pósconstitucional cuja tônica, para a política pública de saúde, é a municipalização.

Incrustado nesse movimento histórico pendular está o enfoque descentralizador encontrado na Constituição Federal de 1988, a qual se caracteriza pela divisão das responsabilidades fiscais e das bases de cálculo tributárias, ajustadas por uma estrutura vertical de transferências financeiras e ao princípio da autonomia administrativa com os Municípios elevados à condição de entes federativos.

É a partir da proeminência que esse debate teve na tomada de decisão constitucional de se organizar o SUS, que acreditamos ser também importante, no estudo das motivações voltadas à estruturação de uma cooperação intermunicipal, a análise da estabilidade política-administrativa dessa estrutura, principalmente sob o enfoque federalista, na medida em que se abordem aspectos sobre o grau de descentralização da tomada de decisão e a formação de conluios dentro dessa estrutura.

Afinal, tanto a descentralização da decisão, quanto a possibilidade de conluios, contribuem para explicar não só o tamanho e o tipo dos entes federativos que tendem a participar de uma estrutura de cooperação, mas também, pode explicar o tamanho da própria cooperação, que via de regra, quando espontaneamente estruturada é formatada por um número pequeno de Municípios, em sua maioria do tipo "latentes".

Evidentemente, seja qual for o formato da estrutura de cooperação desenhado, há que se considerarem os compromissos dos vários entes envolvidos com uma dada política pública de saúde. Para isso, procuramos priorizar dois aspectos, sendo que um deles diz respeito às interações da União, por meio do SUS, com os Municípios, para, então, vislumbrarmos as possibilidades de cooperação intermunicipal. Já o outro seria a própria interação entre Municípios, na medida em que as elites políticas possam identificar compromissos políticos semelhantes, em geral, aqueles baseados na convergência de interesses dos respectivos grupos jurisdicionais de 
consumidores-eleitores envolvidos, os quais se revelariam em processo políticoeleitorais.

Além disso, inferimos que, nas atribuições de responsabilidades entre as elites políticas municipais envolvidas com uma estrutura de cooperação, interferem as complementariedades das várias políticas públicas e a exclusividade de bases tributárias para a coleta de receitas fiscais próprias, uma vez que há uma tendência a se ampliarem os gastos fiscais nos entes municipais e, portanto, se desequilibrar o orçamento público, influenciando na estabilidade das estruturas de cooperação.

Em especial, vimos que os efeitos das ações de outras políticas públicas são também importantes para a estabilidade das estruturas de cooperação de saúde pública. Embora essa complementariedade com outras políticas públicas facilite a constituição da cooperação intermunicipal, também a torna mais instável na medida que seja motivo à desarticulação ou à ruptura em sub-estruturas.

Por isso, flexibilizar as decisões político-municipais com alguma regra democrática, considerando que os consumidores-eleitores têm mobilidade e preferências distintas pela alocação dos recursos, torna-se também inevitável para a constituição da cooperação. Além disso, implica que na barganha política pela formatação de uma estrutura de cooperação intermunicipal, os envolvidos deveriam estar preparados a considerar um duplo enfoque: uma base de motivações comuns e um conjunto de questões em aberto.

A base comum consistiria daquelas políticas públicas sobre as quais todos as elites políticas concordam, sejam elas aderentes, ou não, à constituição de uma estrutura de cooperação para o serviço público de saúde regionalizado. Quanto às questões em aberto, e que não configurem impedimento à prestação regional dos serviços de saúde pública, estas poderiam até ser agrupadas em sub-estruturas na região, participando delas aqueles Municípios que desejam integrar entre si outras políticas públicas sem necessariamente forçar outros a se juntar.

O importante é o "isolamento" de questões atinentes a outras políticas públicas enquanto ocorrer a negociação pela constituição de uma estrutura de cooperação voltada à saúde pública na região, ainda que o sucesso dessas outras subestruturas possa incentivar Municípios relutantes, que exigem esforços maiores de 
coordenação, tornando essa outra política pública complementar também parte da base comum. Afinal, pode também ocorrer o fracasso dessas sub-estruturas, que muito provavelmente seriam desarticulas, embora possamos inferir que não necessariamente afete a base comum voltada à política pública de saúde, na medida em que cada matriz de decisão das elites políticas incorpore mais bônus que ônus na manutenção da cooperação.

No entanto, uma questão de difícil solução é a que se refere a quanta autonomia administrativa e, quanto poder coercitivo, as elites políticas municipais estariam dispostas, cada uma delas, a transferir à burocracia que administra essa estrutura. Evidentemente não há como se medir essa disposição em termos absolutos, embora possamos inferir em termos relativos, que Municípios tendentes a "latente" teriam uma maior propensão a ceder poder de tomada de decisão à burocracia que as elites políticas de Municípios tendentes a "monopsônicos".

Isso significa que esta questão se agrava quanto menos espontânea for a formatação da cooperação, na medida em que os Municípios demandem maiores esforços de coordenação voltados à estruturação da cooperação. Por outro lado, como as elites políticas envolvidas têm a presunção de que tais poderes delegados só seriam legitimados à burocracia se constarem do contrato constitucional, então, um incentivo previsível seria a existências de regras voltadas ao monitoramento da burocracia e, sempre que possível, que fosse exercido também pelos grupos de consumidoreseleitores na medida em que façam representar as respectivas "vozes" em um Conselho Municipal de Saúde, por exemplo.

Finalizando, gostaríamos de retomar as duas questões formuladas no início deste trabalho. A primeira se referia à possibilidade de cooperação entre entes federativos municipais em um ambiente federativo competitivo. A segunda questionava a existência de alguma instituição que pudesse induzir a cooperação intermunicipal. Cremos estar preparados a responder afirmativamente às duas questões propostas, sendo que, em especial à segunda, acrescentaríamos que as normas instituídas pela organização SUS têm incremental e continuamente proposto incentivos aos Municípios para que busquem solução aos seus problemas de insuficiência na oferta de serviços públicos de saúde e, por conseqüência, aos seus problemas de 
externalidade nesse setor, com a formatação de estruturas regionais voltadas à cooperação intermunicipal. 


\section{REFERÊNCIAS BIBLIOGRÁFICAS}

- ABRUCIO, FL e COSTA, VMF: "Reforma do Estado e o contexto federativo brasileiro", Fundação Konrad Adenauer - Pesquisas n. ${ }^{\circ}$ 12, 1998.

- AKERLOF, G: "The Market for Lemons: Quality Uncertainty and the Market Mechanism" , Quarterly Journal of Economics, vol. 84, 488-500, 1970.

- AGUIRRE, BMB; MORAES, MR: "The Federalism Issue in Brazil: The State of Arts of the Theory" , National and Comparative Research from Argentina, Brazil and Germany of the first Arnoldshain Seminar october, 1995, paper, 1996.

- AGUIRRE, BMB: "Federative Aspects of the Public Health Systems Reforms" , ISNIE, mimeo, 1999.

- ALCHIAN, AN e DEMSETZ, H: "Production, Information Costs and Economic Organization" , American Economic Review, vol. 62, 777-795, 1972.

- ALESINA, A; PEROTTI, R e SPOLAORE, E: "Together or separately? Issues on the Costs and Benefits of Political and Fiscal Unions” , European Economic Review, vol. 39, 751/58, 1995.

- AMARAL FILHO, J: "Desenvolvimento regional endógeno em um ambiente federalista", Planejamento e Políticas Públicas, Brasília, IPEA, n. ${ }^{\circ}$ 14, dez., 1996.

- ARRTCHE, MTS: "Tendências no Estudo Sobre Avaliação" ; em Rico, EM (Org..) Avaliação de Políticas Sociais: uma questão em debate, Editora Cortez, 1998.

- BECKER, G: "A Theory of Competition Among Pressure Groups for Political Influence”; Quarterly Journal of Economics 98, número 3, August; 371-400; 1983.

- BHATTACHARYYA, SG, LAFONTAINE, F: "Double Sided Moral Hazard and the Nature of Share Contracts" ， Rand Journal of Economics, vol. 26, 761-781, 1995.

- BIRD, RM: "Aspects of Federal Finance: A Comparative Perspective" , International Symposium on Fiscal Reform, São Paulo, Brasil, set., mimeo, 1993a. 
- BIRD, RM: "Threading the Fiscal Labyrinth: some issues in fiscal decentralization", Symposium on Fiscal Descentralization, National Tax Journal, 46, 207-227, 1993b.

- BOADWAY, R; MARCHAND, M e VIGNEAULT, M: “The Consequences of Overlapping Tax Bases for Redistribution and Public Spending in a Federatiuon” ; Journal of Public Economics 68; 453-78, 1998.

- BRASIL: "Regionalização da Assistência à Saúde: Aprofundando a Descentralização com Eqüidade no Acesso - Norma Operacional da Assistência à Saúde-NOAS-SUS 01/02 (Portaria MS/GMn. ${ }^{\circ} 373$, de 27 de fevereiro de 2002, eregulamentaçãocomplementar)” , em Série A. Normas e Manuais Técnicos, 2. edição revista e atualizada, Ministério da Saúde, Secretaria de Assistência à Saúde, Editora MS, Brasília - DF, 2002a.

- $\quad$ BRASIL: “Reduzindo as Desigualdades e Ampliando o Acesso à Assistência à Saúde no Brasil 1998 a 2002” , Ministério da Saúde, Secretaria de Assistência à Saúde, Editora MS, Brasília - DF, 2002b.

- BRENNAN, G e BUCHANAN, JM; “The Power to Tax: Analytical Foudations of a Fiscal Constitution” , Cambrige University Press, 1980.

- BRICKLEY, JA e DARK, FH: "The Choise of Organizational Form: The Case of Franchising" , Journal of Financial Economics, vol. 18, 401-420, 1987.

- BUCHANAN, JM. e TULLOCK, G: “The Calculus of Consent” , Ann Arbor, University of Michigan Press, 1962.

- BUCHANAN, JM: "ConstitutionalEconomics" , UK: Basil Blackwell, 137p, 1991.

- BUCHANAN, JM: “The Political Efficiency of General Taxation” , National Tax Journal 46, número 4, 401-410, Dec., 1993.

- CARVAlHO, GI e SANTOS, L: 'Sistema Único de Saúde: Comentários à Lei Orgânica da Saúde (Lei 8.080/90 e Lei 8.142/90)" ， Editora Hucitec, 2 edição, 1997.

- COSTA, NR e RIBEIRO, JM: "Política de Saúde e Inovação Institucional: uma Agenda para os Anos 90" , Rio de Janeiro: SDE/ENSP, 1997. 
- DIXIT, AK: “The Making of Economic Policy: A Transaction-Cost Politics Perspective”, Cambridge: The MIT Press, 1996.

- DIXIT, AK e LONDREGAN, J: "Fiscal Federalism and Redistributive Politcs", Journal of Public Economics, vol. 68, 153-180, 1998.

- EGGERTSSON, T: “Economic, Behavior and Institutions” , Cmabridge Surveys of Economic Literature, Cambridge: Cambridge University Press, 1990.

- EGGERTSSON, T: “A Note on the Economics of Institutions” , in Alston, LJ, Eggertsson, T e North, D (eds) "Empirical Studies in Institutions Change", Cambridge: Press Syndicate of University of Cambridge, 1996.

- EVANS, P: “GovermentAction, Social Capital and Development: Reviewing the Evidence on Synergy” , World Development, vol. 24, n. ${ }^{\circ}$ 6, 1996.

- GODARD, O e OUTROS: “Desarrollo Endógeno y Diferenciacion de Espacios de Desarrollo: Un Esquema de Analisis para el Desarrollo Local”, Estudos Territoriales, Madrid, n. ${ }^{\circ}$ 24, 1987.

- GOMES, GM; MACDOWELL, MC: "Descentralização Política, Federalismo Fiscal e Criação de Municípios: o que é mau para o econômico nem sempre é bom para o social" , Texto para discussão número 706 do IPEA, 2000.

- GROSSMAN, SJ e WEST, EG: “Federalism and the Growth of Government" (revisited) Public Choice 79, 19-32, 1994.

- GROSSMAN, SJ e HART, OD: "The Costs and Benefits of Ownership: A Theory of Vertical and Lateral Integration" ，Journal of Political Economy, vol. 94, 691$719,1986$.

- HEIMANN, LS: “A descentralização do Sistema de Saúde no Brasil - uma proposta de investigação sobre o impacto de políticas" , Secretaria do Estado de Saúde-SP, jun., 1998. 
- HIRSCHMAN, A: "Exit, Voice and Loyalty-Responses to Decline in Firms, Organizations and States”, (trad 1973) Coleção Debates em Economia vol. 87, Editora Perspectiva, São Paulo, Brasil, 1970.

- HOLCOMBE, RG: “Tax Policy from a Public Choice Perspective” ; National Tax Journal, Washington, Jun., 1998.

- HOLLINGSWORTH, JR: “Coordination of economic actors and social systems of production”, in Hollingsworth, JR e Boyer, R, (eds) “Contemporary Capitalism: The Embeddedness of Institutions" (Cambridge Studies in Comparative Politics), NY: Cambridge University Press, 1997.

- HOLMSTRÖM, B: "Moral Hazard in Teams" , Bell Journal of Economics, vol. 13, 324-340, 1982.

- HOLMSTRÖM, B: "The Firm as a Subeconomy", Journal of Law, Economics and Organization, vol. 15, 74-105, 1999.

- INMAN, RP; RUBINFELD, DL: "The Political Economy offederal Institutions" , Wharton School, University of Pennsylvania and University of California, Berkeley, 1993.

- KEEN, M: “Vertical Tax Externalities in the Theory of Fiscal Federalism” , International Monetary Fund. Staff Papers - Washington, Sept., 454-84, 1998.

- KLEIN, B e LEFFLER, K: "The Role of Market Forces in Assuring Contractual Performance" $^{\prime \prime}$ Journal of Political Economy, vol. 89, 615-641, 1981.

- KLEIN, B e SAFT, LS: "The Law and Economics of Vertical Tying Contracts" , Journal of Law and Economics , vol. 27, 345-361, 1985.

- KLEIN, B e MURPHY, K: "Vertical Restraints as Contractual Enforcement Mechanisms" , Journal of Law and Economics, vol. 31, 265-297, 1988.

- KLEIN, B: "The Economics of Franchising Contracts", Journal of Corporate Finance: Contracting" , Governance and Organization, vol. 2, 9-37, 1995.

- KLEIN, B: "Why Hold-up Occurs: The Self-Enforcing Range of Contractual Relations", Economic Inquiry, vol. 34, 444-463, 1996. 
- KLEIN, B: "Why Britain is Reorganizing its Nartural Health Service - Yet Again", Health Affairs, vol. 17, n 4, 111-148, 1998.

- LAFONTAINE, F: "Agency Theory and Franchising: Some Empirical Results" , Rand of Journal of Economics, vol. 23, 263-283, 1992.

- MATHEWSON, F e WINTER, R: "The Economics of Franchise Contracts" , Journal of Law and Economics, vol. 18, 503-526, 1985.

- MISOCZKY, MCA: “A Institucionalização do Sistema Único de Saúde (SUS) Sob a Ótica das Relações Entre as Esferas de Governo da Federação” ～; mimeo, 1999.

- MISOCZKY, MCA. e FERREIRA, MF: "SUS: Estratégia de Implementação de Desigualdades"; mimeo, 1999.

- MUSGRAVE, RA: "The Theory of Public Finance" , New York, McGraw-Hill, 1959.

- MUSGRAVE, RA: "Essay in Federalism Fiscal" , Washington, DC: Brookings Institutions, 1965.

- MUSGRAVE, RA: "Leviathan Cometh - Or Does He?" , em Tax and Expediture Limitations, editado por H. Ladd e T. N. Tideman, Washington, DC, Urban Institute, 1981.

- MUSGRAVE, RA: “Who Should Tax, Where and What?” , Tax Assigment in Federal Countries, ed. by Australian National University Press, 1983.

- NEW, B e LE GRAND, J: "Rationing in the NHS: Principles and Pragmatism" , London: King's Fund (pag. 77), 1996.

- NORTH, D: "Institutions, Institutional Change and Economic Performance" , Cambridge: Press Syndicate of the University of Cambridge, 1990.

- OATES, WE: "Fiscal Federalism" , Harcourt, Brace and Jovanovich, New York, 1972. 
- OATES, WE: "Federalism and Government Finance" , em The Economics of Fiscal Ferderalism and Local Finance, edited por Wallace E. Oates, MassachusettsEdward Elgar Publishing Limited, 1998.

- OLSON, M: “The Logic of Collective Action” , Cambridge: Harvard University Press, 1971.

- OSTROM, E: “An Agenda for the Study of Institutions”, , in Public Choice, vol. 48, 3-25, 1986.

- OSTROM, E: “Crossing the Great Divide: coprodution, synergy and development”, World Development, vol. 24, n. ${ }^{\circ}$ 6, 1996.

- PERSSON, T e OUTROS: "The Theory of Fiscal Federalism: what does it mean for Europe?" , paper prepared for the Conference "Quo Vadis Europe?", Kiel, Jun., 1996.

- PERSSON, T e TABELLINI, G; “Federal Fiscal Constitutions: Risk Sharing and Moral Hazard" , Econometrica, vol. 64, 623 - 646, 1996.

- PIKETTY, T: "The Information-aggregation Approach to Political Institutions" , European Economic Review, vol. 43, 791-800, 1999.

- PORTES, A e LANDOLT, P: “The Downside of Social Capital” , The American Prospect, n. ${ }^{\circ}$ 26, mai/jun, 1996

- RIBEIRO, JM e COSTA, NR: "Consórcios Municipais no SUS" , Texto para discussão nº 669, IPEA, 1999.

- RAYNAUD, E: "The Contractual Design of Governance Structure to Manage Shared Brand Name" , ISNIE, mimeo, 1999.

- REIS, EF: “Federalismo Fiscal”, Mandamentos Editora, 2000.

- RINALDI, LB e OUTROS: “Qual a Autonomia Municipal na Gestão da Saúde?”, Porto Alegre: Da Casa Ed., 1996.

- RUBIN, P: "The Theory of the Firm and the Structure of the Franchise Contract" , Journal of Law and Economics, vol. 21, 223-234, 1978. 
- SANTOS, WG: "Cidadania e Justiça: a Política Social na Ordem Brasileira" , Editora Campos, $2^{a}$ edição, 1987.

- SAPPINGTON, D: "Incentives in Principal-Agent Relationships" , Journal of Economic Perspectives, vol. 5, nº 2, 45-66, 1991.

- SHADBEGIAN, RJ: "Fiscal Federalism, Collusion, and Government Size: Evidence from the States” , Public Finance Review (May/1999), Thousand Oaks, 1999.

- SHAH, A: "Perspectives of the Design of Intergovermental FiscalRelations" , mimeo, 73p, 1993.

- SHIKITA, CD: "Emancipação de Municípios em Minas Gerais (1995): uma abordagem novo-institucionalista e de escolha pública" , Dissertação de mestrado FEA-USP, 1998.

- SHIRLEY, MM: "Pressing issues for institutional economists: views from the fornt lines", trabalho apresentado na Conferencia Inaugural da Sociedade Internacional para Nova Economia Institucional, em St. Louis, Set., 1997.

- SOUZA, RR: “Construindo o SUS: a lógica do financiamento e o processo de divisão de responsabilidades entre as esferas de governo" , Dissertação de mestrado, Universidade do Estado do Rio de Janeiro, Instituto de Medicina Social, 2002.

- STIGLITZ, JE: "Más instrumentos y metas más amplias para el desarrollo. Hacia el Consenso Post-Washington”, in Conferencia Anual do Instituto Mundial para a Investigación en Economía del Desarrollo (WIDER) de la Universidad de las Naciones Unidas - Helsinki, 1998.

- TANZI, V: "The Role of the State and the Quality of the Public Setor", IMF Working Paper WP/00/36, 2000.

- TIEBOUT, C: “A Pure Theory of Local Expenditures” , The Economics of Fiscal Federalism and Local Finance, capítulo 22, 1956.

- TIROLE, J: "A Theory of Collective Reputation (with Application to Corruption and Firm Quality)" , Review of Economics Studies, vol. 63, 1-22, 1996. 
- VIANNA, SM: “ADescentralização Tutelada” ; Saúde em Debate, n. 35, 1992.

- WILliAMSON, OE: "The Modern Corporation: Origin, Attributes and Evolutio n", Journal of Economic Literature, vol. 19, 1536-1568, 1981.

- WILliamson, OE: "Credible Commitments: Using Hostage to Support Exchange" , American Economic Review, vol. 73, n 4, 519-540, 1983.

- WILLIAMSON, OE: "The Economic Institutions of Capitalism: Firms, Markets and Relational Contracting" , New York Free Press, 1985.

- WILLIAMSON, OE: "The Economics of Governance: framework and implications", in Langlois, RN (ed), "Economics as a Process: Essays in the New Instituticional Economics”, Cambridge University Press, Cambridge, 1986.

- WILlIAMSON, OE: "Comparative Economic Organization: The Analysis of Discrete StructuralAlternatives" ，Administrative Science Quarterly, vol. 36, 269296, 1991.

- WILLIAMSON, OE: "The Mechanisms of Governance" ，Oxford University Press, 1996.

- WILSON, JD e GORDON, RH: “Expenditure Competition” , Department of Econimics, Michigan State University, mimeo, 1998.

- WILSON, JD: “Theories of Tax Competition” , National Tax Journal, Washington, Jun., 1999. 